\title{
Juliana Davini
}

\section{As forças em jogo na prática de um grupo de formadores de educadores no município de São Paulo: instituição, política e subjetividade.}

(versão corrigida)

Tese apresentada ao programa de pós-graduação em Psicologia Escolar e do Desenvolvimento Humano do Instituto de Psicologia da Universidade de São Paulo, como exigência parcial para a obtenção do título de Doutor em Psicologia sob a orientação da Professora Doutora Marlene Guirado

São Paulo 
AUTORIZO A REPRODUÇÃO E DIVULGAÇÃO TOTAL OU PARCIAL DESSE TRABALHO, POR QUALQUER MEIO CONVENCIONAL OU ELETRÔNICO, PARA FINS DE ESTUDO E PESQUISA, DESDE QUE CITADA A FONTE.

Catalogação na publicação

Biblioteca Dante Moreira Leite

Instituto de Psicologia da Universidade de São Paulo

Davini, Juliana.

As forças em jogo na prática de um grupo de formadores de educadores no município de São Paulo: instituição, política e subjetividade / Juliana Davini; orientadora Marilene Guirado. -- São Paulo, 2011.

$208 \mathrm{f}$.

Tese (Doutorado - Programa de Pós-Graduação em Psicologia. Área de Concentração: Psicologia Escolar e do Desenvolvimento Humano) - Instituto de Psicologia da Universidade de São Paulo.

1. Formação de professores 2. Educação continuada 3. Subjetividade 4. Discurso 5. Análise institucional 6. Política educacional I. Título. 
Nome: Davini, Juliana.

Título: As forças em jogo na prática de um grupo de formadores de educadores no município de São Paulo: instituição, política e subjetividade.

Tese apresentada ao programa de pós-graduação em Psicologia Escolar e do Desenvolvimento Humano do Instituto de Psicologia da Universidade de São Paulo, como exigência parcial para a obtenção do título de Doutor em Psicologia

Aprovado em: 02/05/2011

Banca examinadora

Dra Marlene Guirado

Instituição: IPUSP - PSA

Assinatura:

Dra Terezinha Azerêdo Rios

Instituição: Membro do GEEPEFE - FE- USP

Assinatura:

Dr. Rogério Lerner

Instituição: IPUSP - PSA

Assinatura:

Dra Luciana Valore

Instituição: I. Psicologia, Universidade Federal do Paraná

Assinatura:

Dra Marilene Proença Rebello de Souza

Instituição: IPUSP- PSA

Assinatura: 


\section{Dedicatória}

Aos que vieram antes e me deram tanto

Elyá e Valdemar

Lucy e Rubens

Carolina e Vasco

Ely, Ete, Suely 


\section{AGRADECIMENTOS}

À querida Marlene Guirado por acreditar em minha capacidade nos momentos de dúvidas pelos quais passei, pela orientação sempre preciosa e leitura cuidadosa das minhas produções, me ajudando a encontrar os caminhos. Pelo método fértil que criou e pela inspiração que ele traz para a analítica da subjetividade e para o trabalho da psicologia.

À querida Terezinha Rios que vem me acompanhando em meu percurso de longa data, não me deixando esquecer o que é o mais importante, a "felicidadania" - direção ética em meus trabalhos com educadores - e, pela contribuição afetiva e generosa em minha qualificação que se estenderá, com certeza, na "conversa” final.

Ao Rogério Lerner, professor admirado pelo rigor e simplicidade e que muito ajudou ao clarear o foco deste trabalho em meu exame de qualificação; agradeço desde já as contribuições vindouras.

À Marilene, professora generosa, que vem me acompanhando em meu percurso profissional e vai, com certeza, enriquecê-lo ainda mais com sua participação na discussão deste trabalho.

À Luciana, professora e colega que sempre foi um "modelo" para mim, pela participação e contribuição na discussão deste trabalho.

Às educadoras que aceitaram participar desta pesquisa, confiando na crítica e apostando na minha análise como contribuição.

Ao colega Eduardo que me estendeu a mão com generosidade, me ensinou a me distanciar para fazer as análises e me deu o empurrão que precisava e, ainda, pela grande ajuda na leitura crítica final.

À colega Marta que me ajudou a encontrar meu caminho num momento de grande desânimo.

Aos colegas do grupo de orientação pela escuta, pelas intervenções e análises do material coletado.

Ao Luiz Fernando, companheiro querido, de todos os momentos, incentivador dos meus projetos pessoais. 
Aos filhos Gabriel e Luíza, pelo apoio e pela inspiração que são na minha vida.

À minha afilhada Anaiá, pelo estímulo, pela companhia e por seu sorriso alegre sempre presente.

À Lynn amiga-irmã e parceira de todas as horas e que me ofereceu grande apoio emocional, incentivo e seu olhar carinhoso.

À Cris, irmã-esteio e aos meus pais Elyá e Valdemar: todos presenças de luz em minha vida.

Às amigas do coração: Bel pela leitura crítica de partes do texto e orientação com relação aos temas educacionais, pela aposta e por me ensinar a ousar mais, por me ajudar a buscar uma nova organização para o trabalho; Laís, pela torcida e carinho sempre presentes; Rita por seu entusiasmo de viver e que é uma inspiração; Ana pelos livros, dicas de argumentação, ajuda na construção da apresentação da defesa e papos já bem tarde da noite.

À Iole, pela escuta e pela ajuda no enfrentamento de mudanças pessoais bem como na reorganização da minha energia e equilíbrio interno nos últimos anos. 
Já que se evocaram os fantasmas não é o caso de sair correndo quando eles aparecem

Freud 


\section{RESUMO}

Davini, Juliana. As forças em jogo na prática de um grupo de formadores de educadores no município de São Paulo: instituição, política e subjetividade. 2011. 208f. Tese (Doutorado). Instituto de Psicologia da Universidade de São Paulo. 2011.

Esta pesquisa analisa o discurso de oito educadoras que têm experiências com formação continuada em serviço como membros de equipes técnicas da Secretaria da Educação da prefeitura de São Paulo e das escolas municipais. O método, compreendido como uma estratégia de pensamento, é o da Análise Institucional do Discurso (AID), proposto por Guirado (2010) e se constituiu como um operador da pesquisa, desde a elaboração do problema e da revisão bibliográfica até a produção, mediação e análise do material discursivo dos quatro encontros ocorridos entre as participantes e a pesquisadora. Foi uma experiência de trabalho com o método, em grupo e em ato, na dimensão institucional das relações, o que colocou a atual pesquisadora como coparticipante dos resultados. $\mathrm{O}$ objetivo da pesquisa foi analisar os movimentos ocorridos nas sessões de grupo e, neles, como se deram os processos de construção da subjetividade das formadoras, a partir das forças em jogo nas práticas de formação recebidas e oferecidas no contexto público que sofre alterações a cada mudança de ciclo político. Para chegar aos modos de subjetivação presentes no campo da formação partiuse dos lugares atribuídos aos educadores e a seus formadores, bem como à formação continuada em serviço no contexto público-municipal, definidos pela ordem institucional encontrada a partir da análise da revisão bibliográfica. Em seguida, estabelecem-se os lugares assumidos e construídos para si e para os demais atores institucionais, na perspectiva das histórias contadas pelas profissionais. Os resultados da análise dos textos teóricos mostram um discurso hegemônico a favor do professor pesquisador e reflexivo, do formador "profissional" (que toma a tarefa como o seu compromisso e a sua identidade) e da formação participativa, crítica e transformadora de si e da escola. Em contrapartida, os discursos das formadoras não caracterizam tais lugares para si e para o trabalho, o que evidencia um malestar e um choque de expectativas entre os lugares e perfis prescritos e desejados para fazer face aos problemas educacionais no país e os vivenciados por elas. A análise destes discursos aponta certos lugares ocupados de forma recorrente e circular, os quais caracterizam-se como formações subjetivas: recolhimento individual (vitimização, culpabilização, desqualificação), sujeição burocrática (passividade, apagamento de si, alienação), guerra (disputa, resistência, ataque e defesa), sobrevivência (aguardar, suportar, permanecer), amalgamento (parcerias, apoios e mitificação na busca de iguais). Mostrou-se, ao final, que cada uma ocupou tais lugares a seu modo e fez ensaios de diferença e liberdade em relação às pautas subjetivas construídas institucionalmente. Conclui-se que a atual pesquisa faz uma reflexão crítica sobre a prática de formação continuada em serviço e suas produções e mobiliza o regime de produção de verdades institucionais ao dar visibilidade aos modos de subjetivação produzidos e aos tipos de experiência de si vividas por um grupo de formadoras. O método provou-se fértil para mediação psicológica e análise de discurso em grupo.

Palavras-chave: Formação de professores, Educação continuada, Subjetividade, Discurso, Análise institucional, Política educacional. 


\section{ABSTRACT}

Davini, Juliana. The forces at stake in the practice of a group of teacher educators in Sao Paulo: development, politics and subjectivity. 2011. 208f. Thesis to the Institute of Psychology - USP. 2011.

This research analyzes the discourse of eight educators who have experience with in-service continuing education as members of the Department of Education of the Sao Paulo City Hall and of the municipal schools technical teams. The method, understood as a thinking strategy, is the Institutional Discourse Analysis, as proposed by Guirado (2010). It took place throughout the entire research, from the beginning of the elaboration of the problem, to the bibliographic review and the production, mediation and analysis of the discursive material produced in four meetings between the participants and the researcher. It was a working experience with the method, in group and in act, in the institutional dimension of relations, which put the current researcher as a co-participant of the results. This research aims to analyze the movements in the group sessions and how the construction of subjective processes of the educators occurred, identifying the forces at stake in the education practices in the public context that undergoes changes every political cycle. In order to get to the modes of subjectivity present in the field of education, we started from the roles attributed to the teachers and their educators, as well as the role attributed to the in-service continuing education in the public-municipal context, defined by the institutional order found through the analysis of the bibliographic review. Then, we establish the roles assumed and built for themselves and the other institutional actors, in the perspective of the stories told by the eight professionals. The results of the theoretical texts analysis show a hegemonic discourse in favor of the researcher and reflective teacher, the "professional" educator (who takes the task as their commitment and their identity) and the participatory, transformative and critical education of themselves and of the school. In contrast, the educators' discourses do not characterize such roles for themselves and for the work, revealing a malaise and a clash of expectations between the prescribed and wished roles and profiles to confront the educational problems in the country and experienced by them. The analysis of these discourses points out some roles occupied recursively and circularly by all of them, which we describe as subjective formations: individual gathering (victimization, culpability, disqualification), bureaucratic subjection (passivity, self-effacement, alienation), war (struggle, resistance, attack and defense), survival (wait, endure, remain), amalgamation (partnerships, support and myth in the search of equals). It was shown, in the end, that each participant occupied the roles in their own way and managed to build their subjectivity regarding the institutional issues. We conclude that the current research opens up possibilities for reflection and mobilization of the production system of institutional truths, by giving visibility to the produced modes of subjectivity and to the types of self experience lived by a group of educators. The method proved to be fertile for psychological mediation and for group discourse analysis.

Keywords: Teacher Educators, Continuing Education, Subjectivity, Discourse, Institutional Analysis, Educational Policy. 


\section{SUMÁRIO}

1- INTRODUÇÃ $\mathbf{O}$................................................................................................................12

1.1 - Resgate do meu percurso como pesquisadora ..................................................... 12

1.2 - A reconstrução do conceito de subjetividade .....................................................14

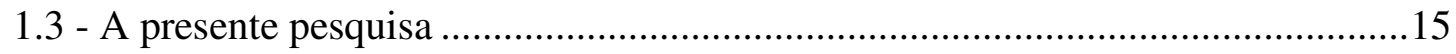

2- TENSÕES NO CAMPO EDUCACIONAL ..............................................................21

2.1. A composição de forças nos diferentes cenários históricos .................................22

2.2 - A preocupação com a formação inicial dos professores......................................26

3 - TENSÕES NO CAMPO DA FORMAÇÃO CONTINUADA EM SERVIÇO...36

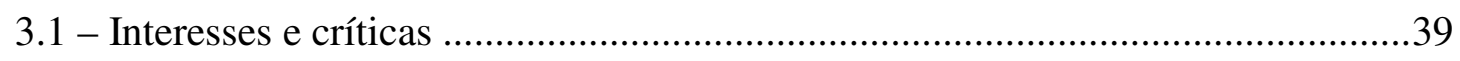

3.2 - Preocupações acerca dos perfis: do educador, da formação e do formador .........43

3.3 - Expectativas em torno das políticas públicas municipais de São Paulo...............54

4 - MÉTODO..............................................................................................70

4.1 - A construção do problema da pesquisa ............................................................. 71

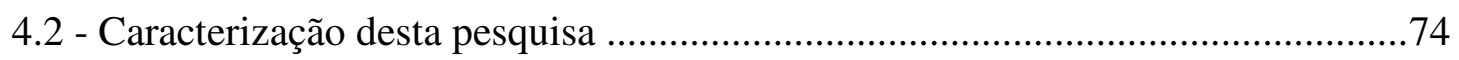

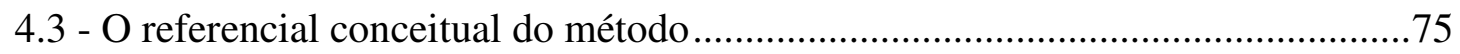

4.4 - Algumas palavras sobre mais um conceito norteador: as relações de poder........81

4.5 - Desafios e exercícios: a distância da pesquisadora do seu campo de pesquisa

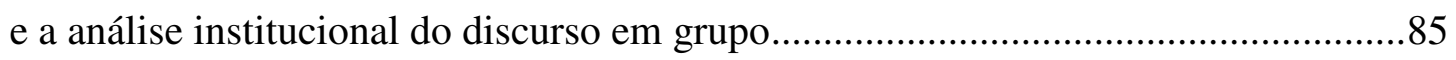

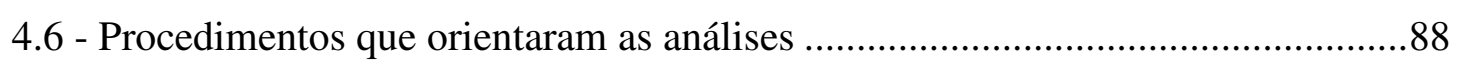

5 - AS SESSÕES DE GRUPO: UMA ANÁLISE.........................................................91

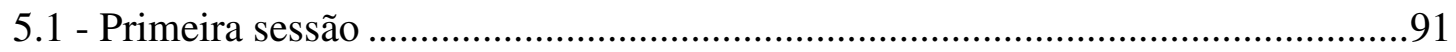

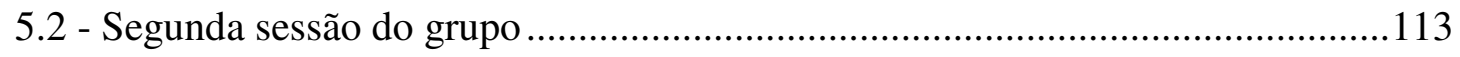

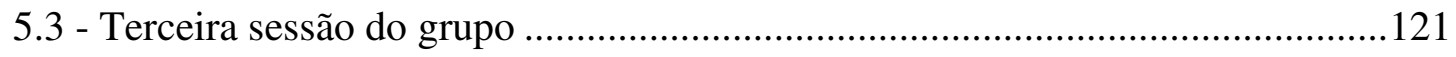

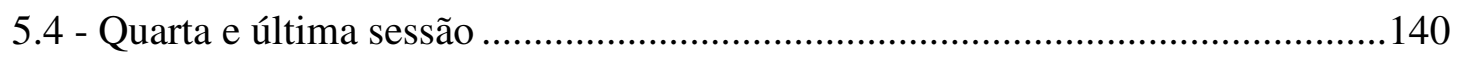

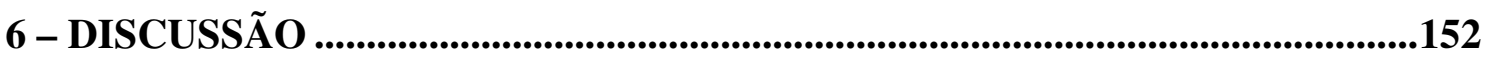

6.1 - Cenas e a relação entre os personagens: uma síntese ......................................152

6.2 - Desenhos, marcas e possibilidades da formação e da subjetividade..................157

6.2.1 - A formação, os formadores e os educadores...........................................158

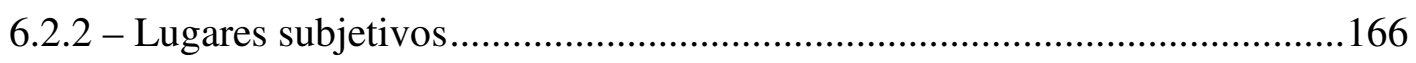




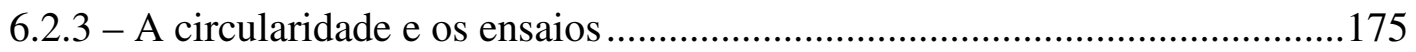

6.2.4 - Singularidade: Clara entre o absurdo e a felicidade ...................................177

6.3 - A relação entre a pesquisadora-mediadora e participantes ................................180

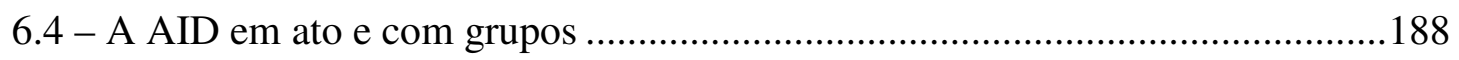

7 - CONSIDERAÇÕES FINAIS .......................................................................192

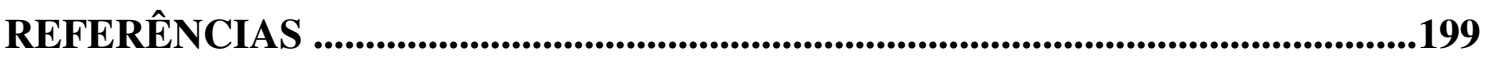

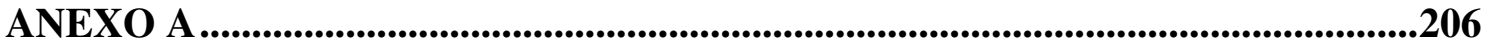

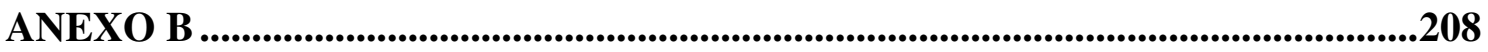




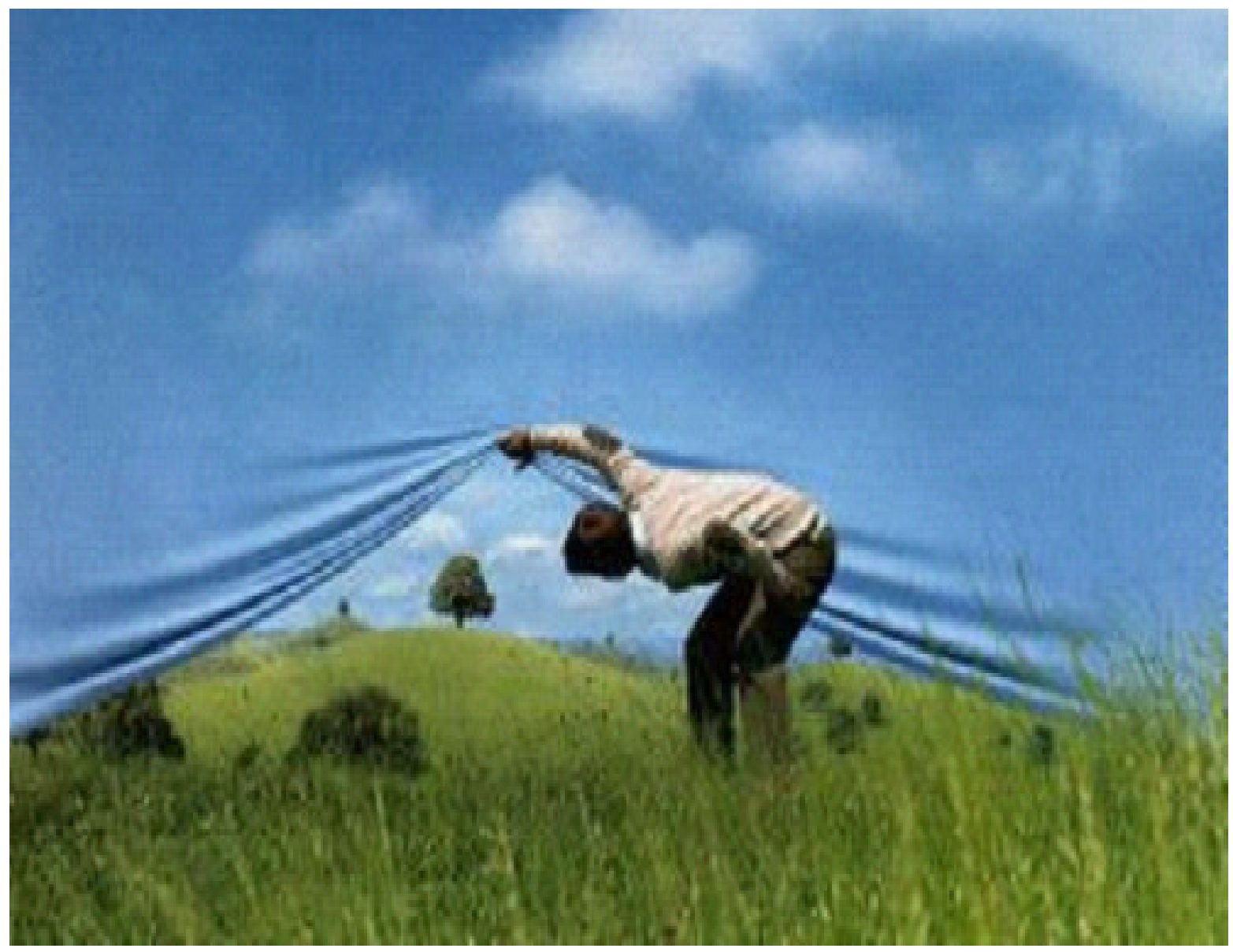

Fonte texto visual: autor desconhecido, caminho, 372X480 cm, 2011.

Disponível em: http://www.google.com.br/search/caminho Acesso em: 02-01-2010 


\section{1- INTRODUÇÃO}

\section{1 - Resgate do meu percurso como pesquisadora}

Como psicóloga escolar com formação em psicanálise tenho trabalhado com formação continuada de educadores desde 1989 e recebido, ao longo dos anos, diversos convites para discussões e estudos em grupo sobre educação e as relações interpessoais na escola, da perspectiva da minha área de conhecimento. Durante os anos iniciais, nos grupos de reflexão, assessorias, palestras e aulas, escutei educadores falando de si nas situações profissionais, nos seus grupos de trabalho e suas instituições: descobertas, perguntas, dúvidas, conflitos e queixas a respeito do universo escolar.

Essa escuta mobilizou, posteriormente, a criação de uma prática de ensino organizada em módulos nos grupos de estudo e reflexão para educadores, dentro de um curso com duração de três anos, de 1992 até $2005^{1}$, numa instituição privada de formação de educadores chamada Espaço Pedagógico.

Durante meu mestrado concluído em $2003^{2}$, sob a orientação da professora doutora Marilene Proença Rebello de Souza, analisei tal prática através do seguinte recorte: acompanhei os discursos de duas alunas ao longo dos três anos do curso de especialização produzidos em alguns módulos que ministrei. Utilizei como material de pesquisa documentos escritos produzidos por elas e por seus respectivos grupos (textos coletivos, textos dos colegas do grupo, textos-síntese) nesse período.

O objetivo foi buscar a contribuição dessa prática para a construção de mudanças profissionais através do que chamei na época de mobilizações nas posições subjetivas iniciais: em relação às queixas que faziam, ao que demandavam, a como se posicionavam frente ao ato de ensinar e aprender, bem como em relação a que questões traziam a partir dos estudos e

\footnotetext{
1 A escola Espaço Pedagógico existiu e funcionou por 13 anos na cidade de São Paulo e sete anos na cidade de Bauru - SP. Ofereceu curso de especialização do tipo lato-sensu para educadores com duração de três anos, além de assessorias, palestras, cursos pontuais - temáticos e projetos institucionais com diferentes objetivos para escolas e instituições socioeducativas.

2 O trabalho de mestrado tem o titulo de "Um espaço singular para o psicólogo: grupos de formação de educadores orientados pela psicanálise e pela psicologia escolar”. Ipusp, 2003.
} 
discussões. Procuramos as torções vividas em tais posições ao longo dos trabalhos a partir da vivência do grupo, que contou com intervenções dos colegas e da professora.

Relendo o trabalho hoje, vejo que o método de análise dos discursos configurou a subjetividade muito mais a partir dos conteúdos das falas: conteúdos que indicavam falas de intimidade, de afeto, de sentidos singulares e de história pessoal. Tanto na produção quanto no manejo dos conteúdos tomados como "subjetivos", estavam os temas das aulas provocando o seu aparecimento (com momentos de reconhecimento e outros de estranhamento), bem como as intervenções da professora a partir de inspirações psicanalíticas de orientação Lacaniana como: fazer a retificação subjetiva (fazer a implicação do sujeito na queixa), usar o recurso da citação (lembrar o dito, propor termos para serem relacionados) e da confrontação (apontar ênfases, repetições, esquecimentos, lapsos, contradições e etc.), inferir sobre os sentidos das ações e das falas (herança interpretativa), entre outros.

O "falar de si" a partir do dispositivo criado - grupo de reflexão - era esperado e configurou as relações entre a professora-psicanalista e o grupo, construindo cenas de ressignificação, insights pessoais e profissionais e, compartilhamento de intimidades. Por outro lado, o formato grupo de estudo configurou a expectativa da professora em colocar luz nos conteúdos subjetivos presentes nas práticas de ensino-aprendizagem (o que é sempre feito a partir de um referencial escolhido pela professora) e das alunas, em se aproximar e se apropriar dos saberes (e verdades que ali se configuravam) da professora e dos autores lidos.

Os pressupostos teóricos compareceram desde o início dirigindo as significações. Assim, termos vindos das teorias como "falo, castração simbólica, preconceito, alienação, sujeito de desejo", eram usados como meio para se chegar à subjetividade e à representação de si.

Hoje, continuo trabalhando com formação de educadores, com grupos de estudo e reflexão e em projetos para instituições escolares e sócio-educacionais, não mais do lado de dentro de uma instituição de formação de educadores, e, ao mesmo tempo, aprofundei meus estudos de psicanálise em outra direção. Com a ajuda do método batizado por Guirado (2009) de Análise Institucional do Discurso (AID) tenho estudado e revisitado conceitos da psicanálise, entre eles, especialmente, o conceito de subjetividade. 


\section{2 - A reconstrução do conceito de subjetividade ${ }^{3}$}

Com a AID, vivo mudanças significativas no modo de pensar, organizar e realizar a presente pesquisa. A subjetividade, antes procurada nos conteúdos das falas e apoiada em teorias, é agora encontrada através de um modo de analisar o discurso. Trabalhar com as novas referências foi o maior desafio experimentado neste processo.

A subjetividade, para a AID, só existe a partir da experiência, por isso ela é singular e regional, configurada a partir do processo. Não se baseia em apresentações prévias do sujeito como sendo aquele entrevisto por um aparelho psíquico que supõe as instâncias de id, ego, superego; sujeito movido por pulsões de tais tipos, que sofre a repressão dos desejos sexuais e etc.; todas compreensões que vão configurar certa organização para a subjetividade. Esta, pela AID, vai ser desenhada a partir dos discursos considerados como ação e exercício relacional que produz efeitos em quem fala e em quem escuta.

Guirado (2009) diz a respeito de modos de subjetivação que são constituídos ao mesmo tempo por:

- uma singularidade historicamente construída e exercitada nas relações concretas que fazemos nos diferentes contextos e em diferentes instituições como a família, o espaço profissional, entre outras; essa singularidade pode ser entendida a partir da ideia do inconsciente como: "registros das experiências, em rede, mediante a inscrição num complexo de memória" (Guirado, 2009, p. 141) ${ }^{4}$. Ou como um jeito de funcionar que comparece e se reedita a cada nova relação (nesse pólo estão os autores das cenas enunciativas que são escutados no movimento de "falar de si", da sua história singular).

3 Consideramos importante colocar na introdução uma apresentação do conceito de subjetividade, no sentido de orientar o leitor, sendo que ele será tratado com mais vagar no capítulo do método.

4 A autora discute no trecho citado um texto Freudiano de 1925, chamado "o Bloco Mágico", e que vamos retomar na discussão: um dispositivo que serve de metáfora para explicar como a vida psíquica inconsciente é produzida em forma de superfície, que é redesenhada a cada reimpressão produzida pelas novas experiências. 
- lugares que geram expectativas e posicionam os personagens nas relações, definidos por uma ordem institucional que os organiza de certa maneira (nesse polo encontramos as condições de enunciação e da produção do discurso).

O conceito de lugar que utilizamos enfatiza que as posições assumidas pelos enunciadores ocorrem a partir de uma dada organização social preexistente e que os ultrapassa e os constitui; a topografia desenhada no discurso funciona como uma matriz institucional. Os enunciadores falam a partir da disposição dos lugares que ocupam e que atribuem aos outros nas relações. O discurso mobiliza um conjunto de regras que domina os enunciadores, no sentido em que os coloca em lugares e em relações (que podem estar mais ou menos conscientes para cada um). As escolhas feitas e os caminhos trilhados vão construindo sentidos e reconhecimentos de si e do outro gerando (maiores ou menores) estabilizações e/ou rupturas.

A subjetividade será resultado, então, da análise do modo como tais lugares e relações são reconhecidos e imaginados (representados) por aqueles que, concretamente, os fazem.

\section{3 - A presente pesquisa}

Por estar sem compromisso com o currículo do curso de especialização nem com uma estrutura formal de escola, tenho a oportunidade de criar espaços de trabalho com os grupos que me procuram a partir de uma escuta sobre a demanda.

Um dos grupos me chamou especialmente a atenção e, mais uma vez, se coloca para mim a questão da subjetividade: esse grupo, composto de educadoras que trabalham na rede da Prefeitura da cidade de São Paulo, me procurou no ano de 2005 para um acompanhamento, propondo, novamente, fazer uma reflexão sobre a prática. Essas pessoas do grupo de 2005 não reconheciam nas propostas de formação continuada oferecidas pela gestão 2005-2008 um espaço genuíno para estudar e pensar a própria prática. Esse mesmo grupo, com outros formatos e composições variadas de participantes, já havia estado comigo outras vezes: primeiro quando fui contratada pela prefeitura na gestão de 2000- 2004 e depois de 2005 a 2006, já fora da prefeitura. 
Fiquei bastante intrigada com os encontros de 2005. As educadoras queriam estar juntas, conversar e mostraram-se muito preocupadas e desanimadas com seu espaço profissional. Havia uma sensação amarga de pouca produção em seus grupos de trabalho na instituição. Falaram de repetições, de retornos a patamares que pareciam já ultrapassados, em resistência às propostas, tanto da parte delas no que é oferecido de formação pela prefeitura quanto de seus educandos, ao que elas propunham como formação continuada em serviço. Em alguns momentos, a fala de uma ou outra educadora apontava para um estado de depressão, no qual as dificuldades no trabalho eram encaradas como problemas e insuficiências individuais. Ao mesmo tempo havia um clima de desesperança, desistência, comodidade em relação ao sistema educacional municipal, apontado como inoperante e cheio de falhas. Elas viviam no momento a mudança de gestão de um prefeito a outro, de um partido político para outro, o que trazia muitas alterações no processo de formação continuada vivido e oferecido, e isso afetava diretamente o cotidiano de trabalho de todas elas.

Algumas perguntas ficaram muito presentes para mim, naquela ocasião, ao longo das conversas sobre suas práticas, colocadas como muito desafiantes: o que estaria havendo com elas? Onde estariam as ferramentas construídas ao longo da formação e que supostamente as ajudariam a enfrentar os desafios e conflitos dos novos lugares profissionais? Como olhar para a repetição da cena/queixa? Que forças estariam em jogo? O quê da estrutura e da política da rede municipal e de cada escola (ou organização) na qual trabalham se apresentaria como elemento motivador de conflito e como estaria, cada uma, respondendo, atuando, participando? Como se percebem e se posicionam no movimento da formação continuada na qual são ao mesmo tempo formadoras e recebem formação? Estas questões mobilizaram-me a continuar meus estudos e em 2006, inscrevi-me no programa de pós-graduação do IPUSP, na área da Psicologia Escolar e do Desenvolvimento, já pensando na possibilidade escolher (recortar) e trabalhar com algumas das questões acima que chamaram a minha atenção no trabalho com aquele grupo.

Em julho de 2007 as procurei, propondo uma nova forma de trabalho que incluía a realização de entrevistas individuais (que acabaram não sendo utilizadas neste trabalho) e de sessões de grupo (que foram taquigrafadas em ato e posteriormente digitadas, constituindo o material desta pesquisa). As perguntas norteadoras da pesquisa e também, das sessões foram: o que se passa com as educadoras formadoras ao longo do seu percurso profissional que é atravessado por mudanças políticas a cada troca de gestão? O que e como falam a respeito 
desse lugar profissional? Como desenham os lugares no discurso? Como se veem e se reconhecem nesse lugar? ${ }^{5}$

Os discursos em análise, neste trabalho, foram produzidos em grupo, em quatro sessões de aproximadamente duas horas.

Considerando a trajetória acima descrita e o jogo de expectativas construído entre nós, o objetivo deste trabalho de doutorado é analisar os movimentos ocorridos nas quatro sessões de grupo, dentro do contexto da pesquisa, e neles, como se deu a construção da subjetividade dessas formadoras de educadores, a partir das forças em jogo nas práticas de formação recebidas e oferecidas no contexto público-municipal que sofre alterações a cada mudança de ciclo político. Através da perspectiva metodológica da análise institucional do discurso proposta por Guirado (2009), analisar que relações se produzem nos discursos, entre as pessoas envolvidas, procurando além das regularidades discursivas, as singularidades produzidas no contexto grupal a partir do relato que fazem sobre a experiência profissional como formadoras de educadores na rede municipal da prefeitura de São Paulo. Com tudo o que isso carreava de expectativas em relação a si próprias, em relação às educadoras com quem trabalhavam, em relação à prefeitura como administração pública e política, como gestão partidária; e enfim, à educação como instituição, com sua clientela, seus agentes e seu objeto institucional; sobretudo quando fazem parte de um grupo que também tem motivações políticas no exercício da sua profissão.

Para isso trabalhei com alguns recortes: (1) que lugares institucionais-subjetivos (subjetividade definida como efeito das relações institucionais) são construídos para si e para os outros envolvidos na cena institucional (como se dão as relações entre educadores formadores e os demais atores institucionais); (2) como é fazer e receber formação na perspectiva do profissional da prefeitura de São Paulo, que a cada quatro anos sofre os impactos das mudanças políticas que alteram os projetos educacionais e os procedimentos da instituição pública; (3) apontar também para o lugar assumido por mim e aquele a mim atribuído, pesquisadora e mediadora das sessões em grupo, no jogo de expectativas cruzadas que se criam e recriam nas sessões.

\footnotetext{
${ }^{5}$ A reconstituição do percurso da pesquisadora com o grupo e a construção do problema de pesquisa será detalhado no capítulo 4 , parte 4.1 .
} 
A contribuição deste trabalho poderá ser (1) metodológica: como com a análise institucional do discurso produziram-se as sessões de grupo; até que ponto a AID em ato se presta a este tipo de mediação grupal e permite, ao mesmo tempo, configurar seu modo de produção (que se preocupou em evitar as significações prévias, as intervenções teóricas e interpretativas, comumente encontradas em trabalhos com grupos de orientação psicanalítica). Ou (2) crítica e reflexiva: trazer do ponto de vista da AID novas luzes para compreensão da prática de formação de educadores, do lugar profissional do formador de educador, identificar as forças em jogo no campo da formação e num certo grupo de formadores, além dos processos de subjetivação decorrentes de um contexto específico de mudança de política educacional na troca de prefeitos na cidade de São Paulo.

A prática de formação de educadores se fazendo como instituição, na condução das sessões de grupo, é outro diferencial desta pesquisa. ${ }^{6}$

Nos dois capítulos iniciais, já exercitando as lentes da AID, trago discussões que ajudam a justificar a relevância do tema da pesquisa ao apresentar um recorte de algumas tensões encontradas ao longo da revisão bibliográfica sobre os lugares atribuídos ao educador e ao formador de educadores nas práticas de formação inicial e continuada. Trabalho também os lugares atribuídos às políticas públicas municipais de São Paulo, tal como aparecem nas pesquisas selecionadas. Escolhi apresentar alguns fatos históricos, legislações e pesquisas em busca de montar um cenário que ajudasse a caracterizar as forças em jogo na disputa de saberes e decisões sobre o objeto: a formação dos educadores.

No quarto capítulo apresento os caminhos percorridos com o grupo até que ele se torne o grupo de pesquisa; depois o método da AID, mostrando-o como um modo de pensar que orienta o fazer e a análise, ao longo da pesquisa. Em seqüência, o campo conceitual que organiza o método: análise, instituição, discurso e subjetividade. Trago ainda o conceito de poder de Foucault, para nos ajudar a olhar para as relações na instituição de formação de educadores. Entro, ao final deste capítulo, nos desafios e exercícios vividos por mim como pesquisadora e termino com os procedimentos que organizaram as análises.

No quinto capítulo apresento a análise do material das sessões de grupo, nas quais os educadores foram convidados a falar de sua vida profissional. Procuro marcar como se deu a produção coletiva de sentidos, pontuando, inclusive, o meu lugar de produção. Coloco o foco

\footnotetext{
${ }^{6}$ Tal diferencial poderá ser mais bem compreendido a partir dos capítulos 4 e 5 .
} 
nos lugares tais como foram exercidos nos discursos, reconhecidos e desconhecidos pelos atores envolvidos e, ainda, nas expectativas que se deram entre os participantes.

O sexto capítulo refere-se à discussão, na qual faço uma síntese de cada sessão no formato de cenas e mostro os vetores de forças no jogo relacional. Em seguida apresento as marcas e as possibilidades desenhadas para a ação formativa e seus personagens, os lugares e formações subjetivas construídas e ocupadas de maneira circular pelas formadoras pesquisadas e, a posição singular de uma das participantes em seu lugar de diferença. Continuo a discussão com uma análise da relação produzida no grupo entre todas as participantes e termino discutindo a experiência da AID em ato e com grupo, feita nesta pesquisa.

Nas considerações finais retomo as inquietações iniciais e indico desdobramentos. 


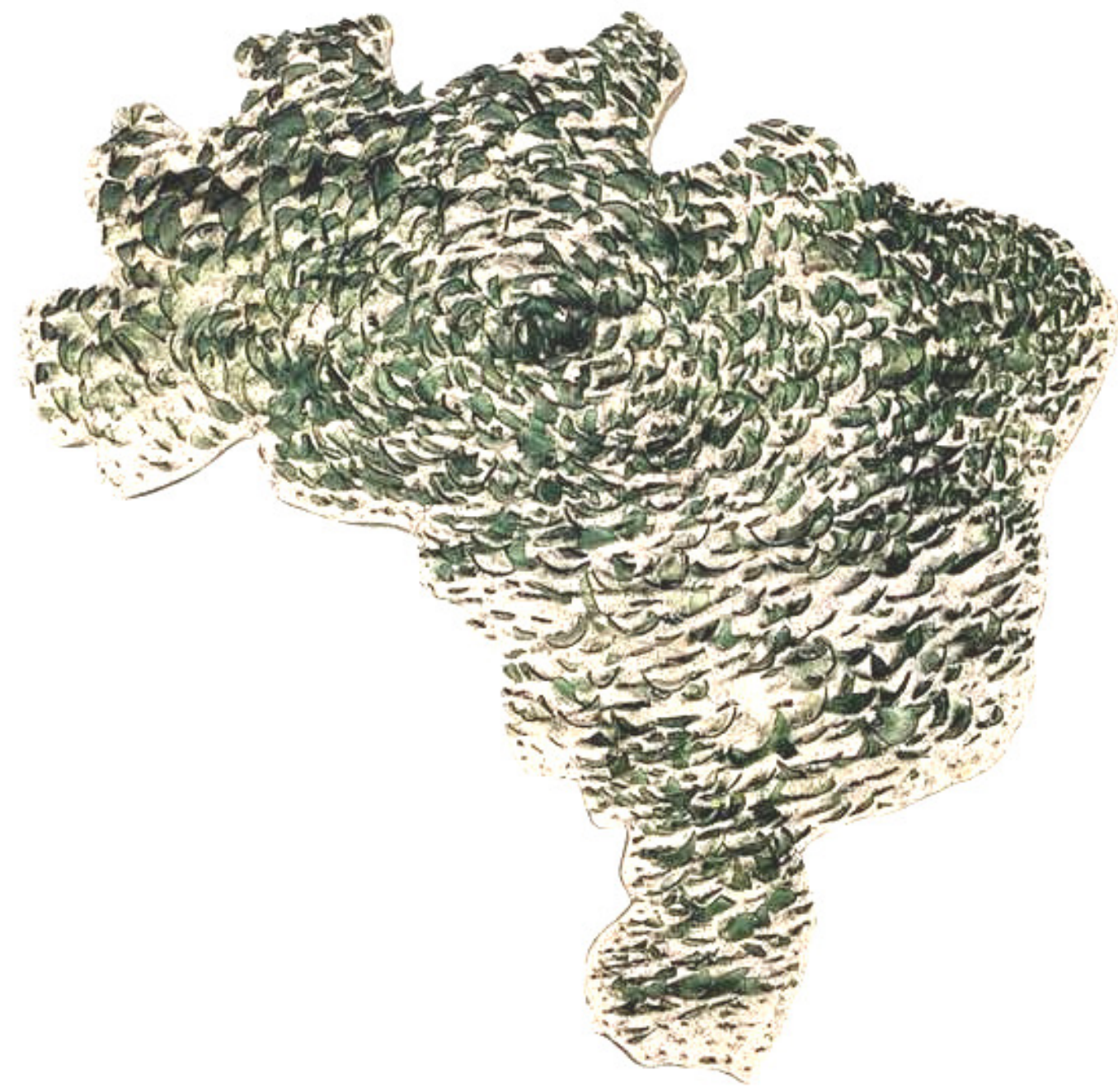

Fonte do texto visual: Ivens Machado, Mapa mudo. Concreto e vidro, 195 x 147 x 8 cm, 1979. 


\section{2 - TENSÕES NO CAMPO EDUCACIONAL}

A educação no Brasil, desde os seus primórdios, evoluiu refletindo as lutas travadas entre as várias camadas que disputaram e disputam o poder decisório acerca da educação pública no país. O grupo que entra para administrar o país, o estado ou a cidade define políticas educacionais e traz propostas para responder aos desafios historicamente constituídos. As reverberações às propostas vêm dos diversos setores da sociedade, que reagem ao produzir novos saberes e pressionar o grupo de decisão, exercendo seus vetores de força, e, com isso, monta-se uma composição de poderes possíveis em cada momento histórico.

Em cada etapa dos ciclos políticos há cenários, personagens, atos, propostas e legislações que compõem e influenciam o jogo de forças em torno do objeto educação, que, por sua vez, invade diretamente o cotidiano dos formadores de educadores, que são aqueles profissionais que vão participar da formação inicial ou continuada do educador em universidades, em instituições privadas ou dentro da própria escola (pública ou privada).

Como no Brasil as eleições ocorrem a cada quatro anos, o campo educacional é atravessado por novas diretrizes, novos materiais didáticos e novos objetivos a cada virada do ciclo político, o que atinge diretamente as práticas. Cada equipe que entra faz uma leitura a respeito dos problemas que encontra e organiza caminhos que julga os mais apropriados para a superação dos mesmos. No decorrer deste caminhar faz escolhas, elege prioridades segundo critérios próprios, mobiliza recursos, profissionais, certos saberes, além de verbas e parcerias financeiras.

Este capítulo pretende apresentar um recorte de algumas tensões em torno da formação da escola encontradas ao longo da revisão bibliográfica e, nesta, o tema da profissão docente no que diz respeito à formação de educadores (formação inicial e continuada). Ao longo da exposição escolhemos trazer alguns fatos históricos, legislações e pesquisas para nos ajudar a montar um cenário em busca de apresentar esse campo: quem são os personagens, como se relacionam e nessas relações quais tensões puderam ser desenhadas.

O recorte feito para tal caracterização buscou identificar as forças em jogo, e o modo como o lugar do professor aparece qualificado nos discursos. 


\section{1 - A composição de forças nos diferentes cenários históricos}

A organização do campo educacional no Brasil não foi sempre como a conhecemos hoje; quando olhamos para a história da educação no Brasil, com a ajuda de Romanelli (2001) e Saviani (2006) ${ }^{7}$, encontramos no Brasil colônia (1500 a 1822) um campo educacional iniciante, influenciado pela cultura europeia e pelos Jesuítas, oferecida para uma minoria, a aristocracia. Como personagens e em campos opostos, disputando o objeto educacional estavam, de um lado, os religiosos e, de outro, o Estado. A disputa se deu em torno dos saberes a serem veiculados na educação: os saberes tal qual foram acumulados e veiculados pelas escolas religiosas e os saberes iluministas dos professores leigos (baseados nos enciclopedistas, filósofos anticlericais que revisaram as artes e as ciências da época), e também sobre as ênfases: ora o ensino básico, ora o ensino superior (o ensino secundário era pouco valorizado, servia de preparo ao superior). A família é um terceiro termo, mas aparece na posição de demandar os serviços educacionais.

O exercício do poder de influência e de posse do objeto educacional foi desigual. No início, a balança pendia para os Religiosos (de 1549 a 1759), ou seja, para o campo privado. $\mathrm{Na}$ época recebiam o incentivo e o subsídio da Coroa Portuguesa, mas mantinham as decisões a respeito dos currículos, das diretrizes, das normas disciplinares, das avaliações, da formação dos docentes e eram os proprietários dos prédios e de sua organização. Ao final do período colonial, as forças penderam para o Estado (de 1759 a 1827), que determinou o fechamento dos colégios jesuítas, introduziu as "aulas régias" mantidas pela Coroa, passou a pagar os salários dos professores diretamente, definiu diretrizes curriculares e deixou a cargo dos professores a infraestrutura (muitas vezes lecionavam em suas próprias casas) e os materiais didáticos.

Os lugares de representação do educador, a partir dos discursos de Romanelli (2001) e Saviani (2006) passaram pelas seguintes caracterizações: lugar de desconhecimento, lugar para atender demandas de instrução definidas pelos familiares, lugar do catequizador, lugar

Romanelli fez uma historiografia da educação a partir dos determinantes econômicos, usando, portanto, critérios externos - os ciclos econômicos - como marcos a partir dos quais buscou compreender a história da educação brasileira e sua política. Saviani, por sua vez, procurou fazer uma periodização a partir de determinantes internos ao processo educativo, ou seja, se balizou pelo modo como a educação era organizada, e assim organizou os cortes históricos.
} 
dependente - ter que seguir os conteúdos do ensino religioso determinado pela igreja, lugar de grande valorização e status social, lugar das elites intelectuais, lugar valoroso por propiciar ascensão social, lugar dependente de modelos e saberes internacionais, lugar de grande autonomia, lugar do cientista e do leigo.

No período seguinte, do Brasil Independente e Imperial (1822 a 1889) alguns novos elementos se introduzem no cenário, ainda segundo Romanelli (2001) e Saviani (2006). O que chama mais atenção é a entrada de novos personagens na disputa pelo objeto educacional exercendo seu poder de influência: a educação, antes só das elites formadas pelos proprietários de terra e pela aristocracia, começa a ser frequentada por uma nova classe social ascendente (a burguesia), que leva para o campo educacional ideias liberais europeias. Formados e escolarizados, esse grupo ascendente começa a ocupar cargos de ensino, administrativos e políticos.

As províncias, através de seus representantes legais, são um novo elemento na cena educacional. Começam a legislar sobre a educação pública primária e média, e o poder central do Governo Imperial fica com o nível superior (o projeto de uma escola pública nacional não ocorreu), mantendo a seletividade ao fazer exames para permitir o acesso a esse nível. Os recursos da Província, segundo os autores, não possibilitaram investimentos para organizar a rede de ensino, a educação secundária ficou nas mãos da iniciativa privada (sendo oferecida então para poucos, pois era paga) e a educação básica, abandonada. A iniciativa privada aparece também como um novo personagem no jogo de forças pela posse do objeto educacional, agora fracionado em partes. As famílias mais abastadas (aristocracia e burguesia) investem cada vez mais na educação, aumentando o status social da profissão. Como pagantes desse serviço, acrescentam à sua posição de consumidores a posição de quem pressiona o ensino em busca de influenciar a sua estruturação, trabalhando para a escrita de novas legislações (extinguindo a seriação, a obrigatoriedade da frequência, e instituindo a matrícula por disciplinas). A pressão das famílias para que o ensino secundário preparasse para o ingresso ao ensino superior acabou por caracterizar os currículos do curso. A igreja ainda se mantém no jogo em instituições privadas, numa posição de menor destaque com relação ao período anterior.

Com relação aos lugares do educador, chama a atenção nesse período a divisão que se estabelece internamente: os professores primários, os secundários e os de nível superior, sendo os últimos os mais valorizados. 
O cenário do campo educacional a partir do Brasil - República (1889) torna-se bem mais complexo e é dessa época para cá que encontramos um formato de escola pública brasileira mais próximo ao modelo atual. Os autores consultados delimitam dois períodos, o primeiro de 1890 a 1930 e o segundo de 1930 em diante.

No primeiro período (1890 a 1930) verifica-se muitas alterações com relação aos personagens que fazem a instituição (a partir de certos saberes), bem como em relação aos lugares atribuídos aos professores. Nesse período, tentou-se implantar muitas reformas educacionais, com objetivo da renovação intelectual e cultural, opondo personagens mais tradicionais (que defendiam a manutenção do status quo) e outros identificados com a renovação a partir do movimento internacional da Escola Nova ${ }^{8}$.

Outra oposição ficou demarcada: dificuldades políticas e de infraestrutura resultaram em mudanças de estatura diferenciada no país, pois com o crescimento da autonomia dos estados as reformas aconteceram de forma diferente em cada região; algumas regiões foram privilegiadas e outras prejudicadas. São Paulo organizou a escola pública primária estadual entre os anos de 1890 a 1896, e esse formato serviu de referência para a sua organização em outros Estados. Nesse modelo, órgãos centrais estaduais ligados a outros órgãos intermediários definiam diretrizes, projetos curriculares (divididos em conteúdos por séries), sistema de avaliação, normas, inspeção e controle das práticas estaduais e eram os construtores e proprietários dos prédios de funcionamento; ofereciam a infraestrutura, definiam o quadro de professores a partir de exigências de formação para admissão e criaram os grupos-classe com um número grande de alunos, todos reunidos num só prédio (acabando com as escolas isoladas), cada classe com diferentes professores, o que exigiu a criação de cargos de coordenação de todas as atividades que aconteciam simultaneamente nas escolas. As escolas foram chamadas de graduadas porque começaram a trabalhar com seriação e a ideia de progressão. Tal formato influenciou também as escolas secundárias (as Normais e as Técnicas) e superiores.

Como podemos ver entram em cena novos personagens e com eles muitas linhas relacionais (e junto com elas, os conflitos potenciais): além dos administradores educacionais

O movimento escola-novista foi inspirado em Jonh Dewey (americano estudioso da linha filosófica da pragmática) que defendia uma escola viva, participativa, aberta aos acontecimentos a sua volta, que trabalhasse não só os conteúdos, mas também os valores democráticos, as experiências, a consciência social. Tal movimento teve muita repercussão, no Brasil, a partir dos anos 1920. 
da Federação, os administradores educacionais de cada Estado, os administradores de órgãos intermediários (como conselhos, inspetoria, diretoria), os coordenadores das atividades da escola, demais funcionários das escolas além dos professores ocupando agora prédios comuns, o que os levou a correlacionar práticas antes muito diversas. Todos eles exercendo sua influência e tentando dirigir as práticas de ensino com os alunos. A dualidade (e oposição) do tempo do Império permanece: a Federação ainda se ocupava mais diretamente das escolas secundárias acadêmicas e superiores (que atendiam aos alunos vindos de camadas economicamente mais abastadas) e os Estados se ocupavam das escolas primárias e secundárias profissionalizantes (que atendiam estratos sociais mais desfavorecidos economicamente). Outro personagem que entra nesse período com mais força na escola é a clientela de alunos vindos dos variados estratos sociais emergentes, e que, com perfis e interesses diversificados, trazem novos desafios para a escola. É notável nesse período a quantidade de pessoas que, dos seus lugares institucionais, começam a organizar saberes sobre como deve ser a prática e o perfil do professor. O professor ganha, na escola, um lugar de redentor, no sentido da grande aposta feita na educação para a transformação e superação dos problemas da desigualdade social. O preparo do professor passa a ser uma preocupação nacional e para melhor definir o seu perfil são criadas escolas-modelo (criadas a partir dos pressupostos republicanos que almejava uma escola de princípios filosóficos modernos e serviu de campo de aplicação das novas teorias educacionais para estudantes do curso Normal).

Romanelli (2001) mostrou como as forças econômicas, políticas e sócio-culturais se equilibram e desequilibram, resultando em organizações educacionais diversas, como demonstrou ter ocorrido por volta dos anos 1920-1930. Segundo a autora, havia até esse período um equilíbrio entre as exigências econômicas, sociais, culturais e políticas: a educação servia para formar uma minoria aristocrática, qualificando também os representantes locais (os políticos e administradores), sendo organizada de forma fragmentária pelo país. A educação seguia modelos europeus, era símbolo de status social, separando classes (os que faziam o trabalho intelectual e os que faziam os outros trabalhos) e consistia num instrumento de ascensão social para os estratos médios urbanos que começavam a despontar. Diz Romanelli (2001, p.46): “A função social da escola era, então, a de fornecer os elementos que iriam preencher os quadros da política, da administração pública e formar a inteligência do regime". A economia não fazia demanda de recursos humanos específicos à escola e os gestores públicos mantinham o status quo. 
A partir dos anos 1930, com a intensificação do processo de urbanização e industrialização, ocorre a diversificação das camadas sociais, a demanda por educação e por recursos humanos para ocupar as novas funções e postos de trabalho. A oferta de escolas era pequena e, além disso, "não correspondia às novas necessidades criadas com a expansão econômica e estratificação social mais diversificada" (ROMANELLI, 2001, p.46), gerando uma crise. O sistema educacional ficou inadequado e instalou-se uma defasagem entre a educação e o desenvolvimento do país. Segundo a autora, a manutenção e o aprofundamento da defasagem iniciada no período descrito é uma herança que perdura até os dias de hoje. Desde a época da industrialização tardia do país temos um desafio educacional quantitativo e outro qualitativo: atender à demanda crescente por escolas (ter escola para todos) e criar currículos que respondam aos anseios socioculturais e econômicos dos diferentes setores da população.

Abrindo a discussão do período de 1930 em diante, Saviani (2006) apresenta uma nova característica que tem a intenção de terminar com uma oposição histórica: a educação nacional passa a ser reconhecida como uma preocupação e muitas reformas e leis são criadas para estabelecer diretrizes e um plano nacional de educação, culminando na escrita da Lei de Diretrizes e Bases da Educação Nacional (LDBEN) de 1961, que legisla também a rede privada de ensino. O movimento da Escola Nova tem um papel importante nesse processo, os saberes veiculados nesse movimento são muito valorizados e inspiram educadores brasileiros a escreverem propostas para a educação pública nacional, buscando, mais uma vez, o perfil que o professor deve ter para construir um ensino que seja transformador ${ }^{9}$. Impulsionado pelo crescimento social e econômico do país, o ensino como direito de todos, dever das famílias e do Estado vem descrito com a Constituição de 1934.

\section{2 - A preocupação com a formação inicial dos professores}

A partir de agora, vamos aproximar o zoom de nossas lentes e nosso recorte percorrerá a preocupação que começa nesse novo cenário: a formação inicial dos professores. $\mathrm{Na}$

\footnotetext{
9 Saviani (2006) define a transformação como sendo uma transformação de si, ou seja, uma mudança em direção a tornar-se um ser humano melhor, capaz de transformar para melhor o mundo ao seu redor.
} 
formação, vamos apresentar as influências e jogos de forças em torno da sua organização. Entendemos formação inicial como a que precede e dá direito ao exercício profissional. Nesse sentido segue a legislação e atende a interesses diversos relacionados às diferentes fases vividas no país.

Segundo Gatti (2009, p.37): “A formação de professores em cursos específicos é inaugurada no Brasil no final do século XIX com as Escolas Normais destinadas à formação de docentes para as 'primeiras letras' [...] devemos lembrar que nesse período, e ainda por décadas, a oferta de escolarização era bem escassa no país, destinada a bem poucos". No início do século XX, com o desenvolvimento industrial do país, começa a crescer a necessidade da escolarização dos trabalhadores o que impulsiona a criação das primeiras formações para professores poderem ministrar a educação secundária (ensino fundamental II e ensino médio, nas nomenclaturas de hoje). Em 1935, com o apoio de Anísio da Teixeira (secretário de educação) é criado o primeiro Instituto Superior para formação inicial de educadores. O curso de pedagogia é regulamentado em 1939 instaurando uma marca que separa professores dos anos iniciais e finais, numa diferença presente até hoje: "fica assim, histórica e socialmente, instaurada, sendo vigente até nossos dias, tanto nos cursos, como na carreira e salários e, sobretudo nas representações da comunidade social, da acadêmica e dos políticos, mesmo com a atual exigência de formação em nível superior dos professores iniciais da educação básica”. (GATTI, 2009, p.38).

A formação inicial acompanha a divisão interna da profissão: há uma formação para quem vai lecionar no curso superior e outra para os que vão para o ensino básico ou secundário.

Nóvoa (1992 b, p.21): diz que “A afirmação profissional dos professores é um percurso repleto de lutas e conflitos, de hesitações e recuos. O campo educativo está ocupado por inúmeros atores (Estado, Igreja, Famílias, etc.) que sentem a consolidação do corpo docente como uma ameaça aos seus interesses e projetos". E salienta que "A compreensão do processo de profissionalização exige, portanto, um olhar atento às tensões que o atravessam”. (NÓVOA, 1992 b, p.21).

As instituições Estado, Igreja e Família, vindos do tempo do Brasil colônia, encontram novos atores como os grupos de empresários da iniciativa privada, educadores das universidades e da sociedade civil para dividirem as relações de força e influência, em torno de como deve ser o ensino, como veremos no trecho que segue. 
A constituição de 1937 ocorreu no entre guerras e, segundo Gatti (2009), valorizou o ensino profissional para o preparo de mão de obra qualificada para o mercado, deixando para a iniciativa privada outros objetivos científicos, tão valorizados e debatidos nos anos anteriores. Com o final da guerra, a discussão sobre a educação ser direito de todos, obrigatória e oferecida pela União foi retomada, e muitas iniciativas foram tomadas para alfabetizar a população. Uma reforma geral foi escrita em 1948, presidida pelo educador Lourenço Filho, resultando treze anos depois na Lei 4.024/1961, bem diferente do projeto original, pois prevaleceram as reivindicações da Igreja Católica e dos donos de estabelecimentos particulares de ensino no confronto com os que defendiam o monopólio estatal para a oferta da educação aos brasileiros.

Mais uma oposição se apresenta: de um lado o governo declarando seu interesse em qualificar mão de obra e alfabetizar a população e de outro, interesses científicos ao lado da iniciativa privada. O modo como o ensino público é organizado afeta diretamente a formação inicial dos educadores que deve estar pronta para atender a uma demanda de alfabetização em massa ou aos objetivos científicos ou ainda preparar mão de obra qualificada para o mercado.

Desde os anos 1920 e, especialmente a partir dos anos 1950, com a industrialização já em grande escala e o impulso rumo ao desenvolvimento, o problema da educação popular foi sendo muito debatido. Havia pressão de grupos de operários afiliados a sindicatos e intelectuais que defendiam a formação de uma consciência crítica na formação dos educadores, movimento que foi violentamente combatido e destruído no início da década de 1960 por ter sido considerado perigoso para o país, segundo Destro (1995).

Lima (2001) em sua tese de doutorado apresenta a formação do educador como uma preocupação muito presente em 1964, o que exemplifica a presença do interesse do Estado, explicitada acima na fala de Nóvoa. Nesse momento, diz a autora, muitos intelectuais foram considerados subversivos e substituídos rapidamente; houve pressa do governo em criar novos quadros e assim houve muitas iniciativas das Secretarias Estaduais e Municipais para a formação inicial de educadores. A preocupação política foi de formar técnicos da educação a serviço da política educacional vigente. Os representantes do poder consideravam que os educadores deveriam ensinar o que lhes fora proposto e não pensar nem participar politicamente do país.

Durante o regime militar (1965-1985) as iniciativas foram sufocadas, qualquer expressão popular contrária aos interesses do governo foi reprimida e a Lei 5.692, a LDBEN, de 1971, deu novamente à formação educacional um objetivo profissionalizante, técnico, 
alega Gatti (2009). A legislação até 1971 não apresenta mudanças significativas na estrutura dos cursos de formação inicial: para professores primários, as Escolas Normais de nível médio e para os professores do secundário, as licenciaturas em cursos de nível superior. Segundo Gatti (2009, p.41): "Normatiza-se a formação do pedagogo com ênfase na formação do especialista, correspondendo ao modelo educacional tecnicista ${ }^{10}$ hegemônico no período". Em 1971 cria-se a Habilitação Específica para o Magistério em lugar das Escolas Normais. De acordo com Gatti (2009, p.38) “a formação perde algumas de suas especificidades, dado que, sendo uma habilitação entre outras, deveria ajustar-se em grande parte ao currículo geral de segundo grau (hoje, ensino médio)". A autora continua: "As pesquisas mostram que acabou ocorrendo uma descaracterização crescente dessa habilitação" (GATTI, 2009, p.39).

As investidas do Governo no período ditatorial caracterizam a profissão docente como técnico, encontrando resistência dos intelectuais, que defendiam um perfil crítico, participativo e transformador da realidade do país.

As ideias sobre formação inicial dos educadores no Brasil também sofrem a influência e servem aos interesses de organismos internacionais, como a UNESCO ${ }^{11}$, como explica Lima (2001, p.39): “A tutela e a dominação dos países desenvolvidos repercutem na formação da força de trabalho esperada, o que resulta na preocupação com a planificação educacional dos países dependentes, na forma de programas vindos de agências financiadoras internacionais”. Segundo Lima (2001), o trabalho de planificação mundial faz com que a educação ganhe características universais (as condições da formação são pensadas independentemente da realidade de cada local). Os autores Cunha, Ludke e Moreira (1999), dizem que as políticas do Banco Mundial ${ }^{12}$ são um conjunto de propostas de economistas para educadores

10 A autora define o tecnicismo como uma prática de aplicação de saberes produzidos por especialistas, muitas vezes em formatos de planejamentos homogêneos, prévios e apostilados, repetida por educadores considerados como técnicos da educação.

11 Para aprofundamento, ver o documento referência das políticas da UNESCO: Educação: um tesouro a descobrir. Relatório para a UNESCO da Comissão Internacional sobre Educação para o século XXI. São Paulo: Cortez, Janeiro de 1998.

12 Criado durante a Conferência de Bretton Woods, na cidade norte-americana homônima, em 1944, no processo de construção da hegemonia internacional norte-americana após a $2^{\mathrm{a}}$. Guerra Mundial, o Banco Internacional para a Reconstrução e Desenvolvimento (BIRD) ficou conhecido, genericamente, como Banco Mundial. Abrange uma série de outras instituições (o próprio BIRD, a Associação Internacional de Desenvolvimento - IDA, a Corporação Financeira Internacional - IFC, o Centro Internacional para Resolução de Disputas sobre Investimentos - ICSID, a Agência de Garantia de Investimentos Multilaterais - MIGA e o Fundo Mundial para o Meio Ambiente - GEF). Diferentemente de seu objetivo inicial, ainda no final dos anos 1960, a linha de atuação do Banco Mundial passou a ter como um de seus focos principais a área educacional, sobretudo nos países latino-americanos, o que se intensificou sobremaneira nos anos 1980-90. Desde então, as diretrizes do Banco Mundial vêm sendo utilizadas como fundamento principal para as políticas educacionais brasileiras, no 
executarem. No discurso trazem as leis de mercado, aproximações da escola com a estrutura da empresa e o ideal da eficiência técnica. Consideram, ainda, frágeis as bases de pesquisa que servem de apoio para as propostas: “os estudos não são concludentes e não raro, partem de objetivos, marcos teóricos e metodologia diferentes. Ao se juntar tudo isso, justapõem-se coisas que não são compatíveis”. (CUNHA et al., 1999, p.283). Tirar conclusões válidas para o Terceiro Mundo em geral, como se fosse um bloco único e ainda por cima a partir de estudos feitos pelo Primeiro Mundo é outra crítica aos financiadores mundiais ${ }^{13}$.

Novos personagens, agora internacionais, entram diretamente em cena, propondo caminhos, políticas e metas para a educação pública brasileira, legitimados em sua intervenção pelas somas financiadas. Mas, também entram no jogo através dos estudos, teorias e práticas, procuradas pelos atores nacionais em busca de soluções aos problemas nacionais como podemos ver em seguida.

Nos anos 1980, com a retomada democrática, observou-se um movimento crítico a respeito da adesão dos educadores aos modismos que aportavam na educação, muitos deles vindos do exterior (Europa e EUA) e a criação de várias pesquisas ligadas às Universidades que analisavam propostas internacionais aceitas no Brasil, propondo estudos e discussões, principalmente nos anos 1990. Os estudos de Cunha et al., (ibidem), são exemplos de análises das políticas europeias e das influências delas nas políticas Brasileiras e na delimitação de um lugar de ambiguidade para o professor. Defendem que o Brasil já está suficientemente maduro para dialogar com os "interlocutores internacionais em nossos próprios termos, sem ignorar a importância de sua contribuição, mas sem embarcar em soluções apressadamente transpostas" (CUNHA et al., 1999, p.279). Acrescentam, também, que não há reforma que possa deixar de passar pelo filtro da aprovação dos professores, que têm ao seu lado o poder da resistência. Dizem que nos discursos internacionais há forte desvalorização profissional dos educadores, juntamente com o lugar de "grupo decisivo" para a construção e mudança do futuro, caracterizando a ambiguidade: "a formação de professores está sendo considerada uma

contexto da reforma do Estado e da educação. Site consultado em 15 de outubro de 2010. $\underline{\text { http://www.histedbr.fae.unicamp.br }}$

13 Para saber mais, consultar os seguintes documentos do Banco Mundial: El financiamiento de la educación en los países en desarrollo: opciones de política (1986); Educación primaria (1992); Lo que el trabajo requiere de las escuelas (1992); Prioridades y estrategias para la educación - estudo sectorial del Banco Mundial (1995); La enseñanza superior: las lecciones derivadas de la experiência (1995); El Estado en un mundo en transformación (1997). 
atividade muito rendosa nos Estados Unidos, pois se trata de um profissional permanentemente necessário e de um investimento de aproximadamente US\$ 3 bilhões anuais (UERJ 13/9/1999)" (CUNHA et al., 1999, p. 281). A caracterização do perfil exigido do professor por influência dos acadêmicos americanos e ingleses, por exemplo ${ }^{14}$, foi a de um profissional que valoriza a pesquisa e a ciência, que é capaz de iniciativa pessoal, autocontrole e de colaboração. Nesse perfil, dizem os autores, estão privilegiadas a racionalização e a autonomia. Mas em contradição com o discurso da autonomia, dizem Cunha et al., (ibidem, 282): "para garantir a qualidade e a eficácia dos sistemas de ensino, as políticas educativas apoiam-se em processos mais estritos de avaliação e controle dos conteúdos e resultados do trabalho escolar, propostos pelos experts". O currículo fica mais padronizado, os alunos e professores são testados e as práticas são normatizadas, gerando uma competição por resultados.

Segundo Libâneo e Pimenta (1999, p.240): “O marco histórico de detonação do movimento pela reformulação dos cursos de formação do educador foi a I Conferência Brasileira de Educação realizada em São Paulo em 1980, abrindo-se o debate nacional sobre o curso de pedagogia e os cursos de licenciatura" e, com ele, a discussão sobre o perfil nacional e regional a ser construído pelos cursos iniciais de professores em diferentes regiões do país.

Os educadores tomam para si a problematização sobre seu perfil, trabalhando em cima de um mal-estar sempre presente: alcançar um perfil nacional, respeitando as características regionais. A partir da abertura política, profissionais envolvidos com o ensino organizam seus saberes e os divulgam, protagonizando sua força em busca de influenciar os rumos na educação pública brasileira, como verificaremos na discussão a seguir.

Muitos foram os debates e "lutas" que culminam na escrita da nova LDBEN de $1996^{15}$, que organiza a formação inicial do professor em nível superior para todos e a

14 Ver também estudos de Popkewitz, T.S. Sociologia política de las reformas educativas. Madri: Morata, 1994. E: Popkewitz, T.S. Academic discourse, profissionalization, and the construction of the teacher in the USA. Helsinki, 1995. (mimeo).

15 LDBEN/1996 - Art. 62 . A formação de docentes para atuar na educação básica far-se-á em nível superior, em curso de licenciatura, de graduação plena, em universidades e institutos superiores de educação, admitida, como formação mínima para o exercício do magistério na educação infantil e nas quatro primeiras séries do ensino fundamental, a oferecida em nível médio, na modalidade Normal.

Art. 87. É instituída a Década da Educação, a iniciar-se um ano a partir da publicação desta Lei.

\$ $\mathbf{4}^{\mathbf{0}}$. Até o fim da Década da Educação somente serão admitidos professores habilitados em nível superior ou formados por treinamento em serviço. 
complementação de titulação aos professores anteriores à legislação e que fixa o prazo em 10 anos para as adequações de titulação. Libâneo e Pimenta (1999, p.242) fazem uma análise crítica da nova LDBEN e escrevem um documento norteador para elaboração de diretrizes curriculares para o curso de formação de pedagogos e de professores (licenciaturas) no qual defendem que a formação básica seja feita "nas atuais faculdades de educação" que também devem oferecer formação continuada e pós-graduação, mantendo articulação com as demais instituições formadoras. Os autores preocupam-se em não deixar a formação do pedagogo ser reduzida à docência, querem incluir e articular na docência o campo teórico-investigativo, possibilitando com isso também a formação de profissionais não docentes. (planejadores, avaliadores, especialistas em gestão etc.) e de educadores para atuar em contextos não escolares.

Visando unificar os currículos e programas de formação de professores das diversas instituições, o Conselho Nacional de Educação elabora e publica a Diretriz Curricular Nacional de 2001, que segundo Brzezinski (2002, p.15):

Tais diretrizes institucionalizam a formação preferencialmente fora da universidade e destinam muito mais para conceder uma certificação do que conferir uma boa qualificação aos futuros professores ingressantes no sistema educacional e aos leigos que nele atuam. As diretrizes curriculares propõem um modelo em que o preparo do professor centra-se no desenvolvimento de competências para o exercício técnico profissional. Trata-se de uma formação prática, simplista e prescritiva, baseada no saber fazer para o aprendizado do que vai ensinar.

Novamente se apresenta a desvalorização em torno do ensino técnico, organizado pelo governo, para grandes massas de professores. Da mesma forma, um tema de grande tensão é retomado pela política: há diferença na formação dos professores dos anos iniciais e dos demais?

Segundo Gatti (2005), as discussões e embates sobre os institutos superiores de educação (ISE) assumirem a formação de parte dos educadores (educação infantil e do fundamental 1) no lugar dos cursos de pedagogia feitos em Universidades, ocorreu porque o governo de Fernando Henrique Cardoso (1995 a 2002), para melhorar a educação básica, negociou com os empresários da educação a fatia do ensino superior, facilitando a criação da 
ISE. A reação de pedagogos e estudantes de pedagogia mostrou que a procura hoje é muito maior pelos cursos de pedagogia que oferecem a formação completa.

Os argumentos a favor da formação inicial do pedagogo ser feita na universidade segundo Brzezinski (2002, p.15, grifo do autor) são:

A defesa da política global de formação e profissionalização do magistério parte da concepção de que o professor é o profissional que domina o conhecimento específico de sua área e os saberes pedagógicos, em uma perspectiva de totalidade. Isso lhe permite perceber as relações existentes entre as atividades docentes e a globalidade das relações sociais: políticas e culturais em que o processo educacional ocorre e atuar como agente de transformação da realidade. Com essa identidade, o professor é o profissional dotado de competência para produzir conhecimento sobre seu trabalho, de tomar decisões em favor da qualidade cognitiva das aprendizagens escolares e, fundamentalmente, de atuar no processo constitutivo da cidadania do "aprendente", seja ele criança, jovem ou adulto.

Como se pode perceber, existem muitas tensões em jogo na definição dos caminhos e na compreensão dos problemas e necessidades educacionais do país e, portanto, em torno da identidade necessária a ser construída a partir do modo como o lugar do educador é visto ao longo do tempo.

A partir dos anos 1930, observamos nos discursos dos autores pesquisados recorrências e novos lugares de representação para os professores: lugar dependente de modelos e saberes internacionais, lugar do técnico, lugar do executor, lugar do prático, lugar de ser pensante que intervém criticamente na relação entre educação e sociedade, lugar de grande preocupação nacional, lugar de objeto disputado por interesses econômicos e políticos (lugar rendoso), lugar disputado por saberes privados e públicos (Universidades e Institutos Superiores), lugar de desigualdade entre seus pares (educadores de educação infantil, fundamental, médio e superior), lugar perigoso a ser reprimido, lugar de características universais (iguais), lugar de resistência e de possibilidade de protagonismo, lugar de valor ambíguo: positivo por ser o responsável pela construção da esperança de futuro versus desvalorização pela incompetência nessa tarefa.

Pensar o perfil a ser construído implica tanto em organizar a formação inicial como em reorganizar os perfis dos profissionais em serviço. Segundo Collares, Geraldi e Moysés (1999, p.203): 
A geração de professoras e professores que iniciou suas atividades nas escolas públicas a partir de meados dos anos 1970 talvez tenha sido aquela que mais foi chamada a "qualificar-se". Como professores, todos nós, em algum momento fomos chamados a "qualificação", ora porque uma nova lei havia sido promulgada, ora porque um novo governo assumia para tudo mudar mantendo a mesmice da escola e suas mazelas, ora porque a formação inicial que tivemos era submetida a uma avaliação negativa, o que impunha que fôssemos mais bem preparados, ora porque modelos metodológicos cientificamente embasados, tornados modismos, perdiam sua hegemonia.

Vamos a partir deste ponto, buscar as influências e jogos de forças no campo da formação continuada em serviço. 


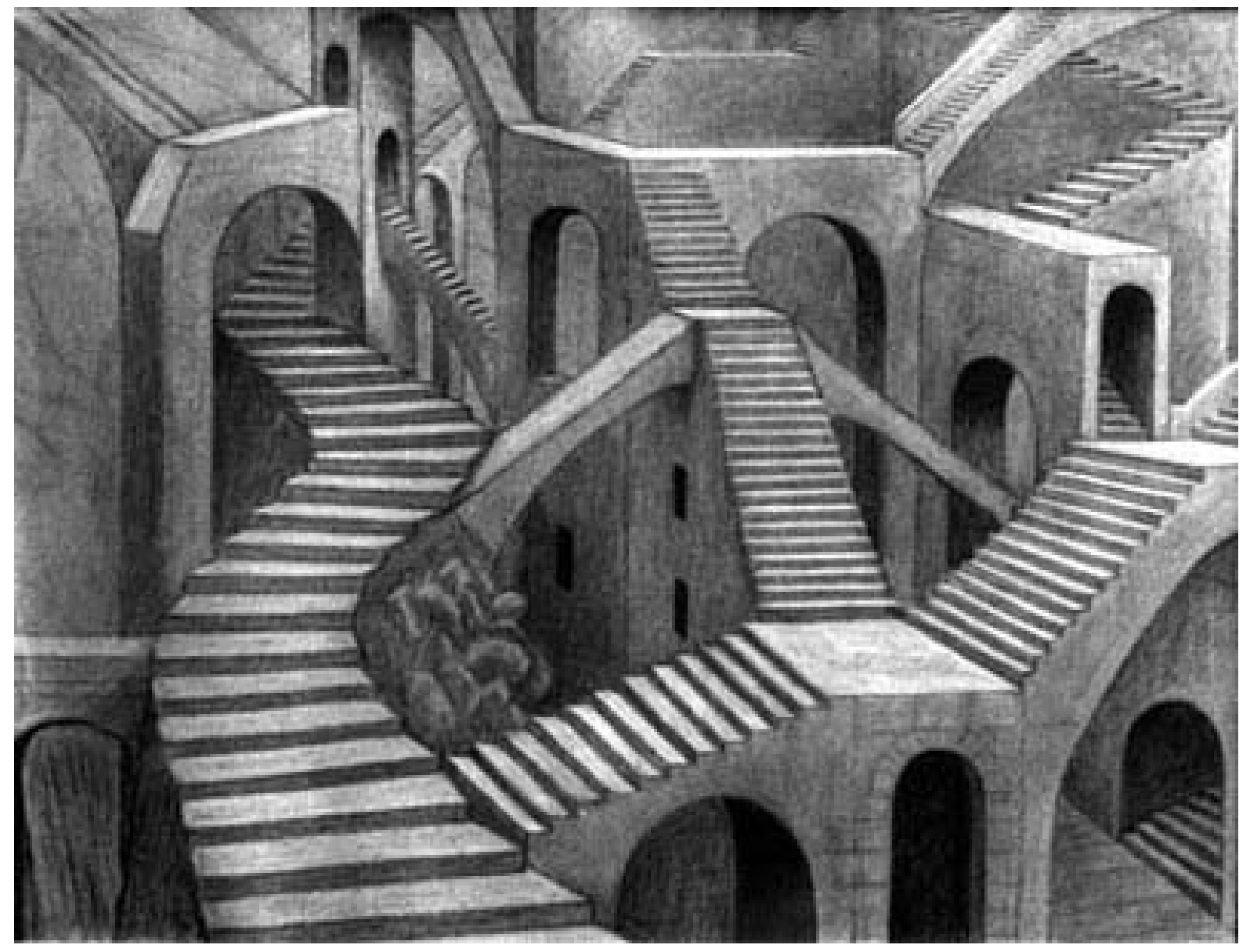

Fonte do texto visual: Maurits Escher, Relativity, 1953. 


\section{3 - TENSÕES NO CAMPO DA FORMAÇÃO CONTINUADA EM SERVIÇO}

Entendemos a formação continuada como aquelas práticas que são feitas após a graduação e/ou, titulação inicial, como cursos, palestras, grupos de estudo, grupos de reflexão, hora de trabalho coletivo na escola, ou cursos mais estruturados como os de pós-graduação, especialização, entre outros.

A formação continuada em serviço, no caso da esfera pública, é compreendida como uma modalidade de acompanhamento e formação para educadores em exercício. Pode ser feita no local de trabalho (chamada de formação em serviço) ou fora dele. Ela se dirige a profissionais que ocupam os cargos de professor, auxiliar, orientador, coordenador, assistente, diretor, entre outros, é oferecida pelo poder público e está diretamente ligada ao programa educacional do partido político que faz a gestão municipal, estadual ou federal. O partido político vencedor das eleições, além de imerso numa dada composição histórica que articulou de certa maneira os fatores econômicos, sócio-culturais e políticos, tem uma visão sobre o papel do Estado frente à tarefa educativa e vai organizar (ou não) a formação continuada em serviço a partir de uma concepção, enfatizando alguns aspectos e possibilidades da mesma, e assim propõe um modo de interação com uma rede de ensino complexa e desafiante, cheia de tensões e heranças, como ocorre com a rede pública Brasileira.

A formação continuada tem estreita relação com a formação inicial, já que sua necessidade nasce em meio ao percurso histórico da tentativa de organizar as competências necessárias para a atuação (considerada a mais adequada) do professor, diante dos desafios da realidade: aumento de demandas de vagas e de escolas (cada vez mais alunos são atendidos e trazem com eles, para a escola, a diversidade), mudanças dos currículos e projetos escolares, que também foram mudando muito em nosso país na tentativa de enfrentar o grande desafio de ensinar a todos e combater a repetência, a evasão, a indisciplina e o não aprendizado dos alunos.

A formação continuada nasce em meio a um campo tenso, pois está atrelada aos problemas concretos vividos nas redes, constatados através de pesquisas, avaliações, concursos e assim por diante. Um dos objetivos bastante encontrados na bibliografia em relação à formação continuada de educadores em serviço é, com a ajuda e parceria das Universidades, ultrapassar a visão fragmentada da realidade (DESTRO,1995). 
A formação continuada é apresentada também como uma atividade fundamental para o constante desenvolvimento e aprimoramento profissional do indivíduo e da sociedade. Pode, no entanto, cumprir diferentes papéis no contexto educacional: atuar como programa compensatório de formações iniciais precárias e insuficientes, ou atender ao discurso das atualizações e da necessidade de renovação do mundo globalizado, cheio de novas tecnologias e que exige especializações como requisito para o trabalho.

Há uma grande diversidade de formações continuadas oferecidas no Brasil: as que são feitas dentro do sistema público, através do sistema privado e, ainda, as oferecidas pelo terceiro setor; todas com durações e exigências muito variadas. Há também as formações complementares, que são criadas pelo setor público, para professores em exercício que não tenham as titulações exigidas. Nesse sentido a pesquisa desse campo se torna uma tarefa gigantesca, e mesmo que tenha crescido nos últimos dez anos, podemos considerar que as pesquisas são ainda muito incipientes.

A legislação acompanha os impasses, os questionamentos, as negociações políticas, e se desenvolve no sentido de atender aos anseios das forças em jogo no cenário educativo. Nesse sentido, a formação continuada de educadores e a formação dos formadores é uma discussão muito recente, como podemos ver no documento atual que oferece diretrizes para a educação nacional: na LDBEN/96, nos artigos 80, 67 e 40, no qual a formação continuada é incentivada. Nestes artigos o aperfeiçoamento contínuo é descrito como uma obrigação dos poderes públicos, há menção sobre remuneração, uso da formação a distância que é definida como estratégia para a formação para o trabalho.

Seguem à Lei iniciativas no levantamento de recursos para a educação continuada em serviço, e, em 1998, com a criação do Fundo de Manutenção e Desenvolvimento do Ensino Fundamental (FUNDEF) ${ }^{16}$, houve um respaldo legal que possibilitou o financiamento sistemático do Estado e Municípios aos cursos de formação.

As propostas de formação continuada multiplicaram-se de 1990 para cá, em todos os setores (Público, Privado, ONGs e Associações), trazendo preocupações acerca da validade e eficácia das mesmas, o que impulsionou pesquisas sobre a validade das mesmas, bem como a discussão sobre a adoção de critérios, credenciamento e a prática de fazer avaliações externas

\footnotetext{
16 Fundo criado em 1998 para financiar o ensino fundamental, usando até $15 \%$ dos recursos vindos dos principais impostos municipais e estaduais na educação.
} 
que sirvam para medir os resultados. A proliferação de cursos e sua grande procura mostram um novo espaço de mercado se consolidando, como diz Gatti (2008, p.65), há muita oferta e muita procura, e dos anos 1990 em diante "a educação a distância ou mista tem sido o caminho mais escolhido para a educação continuada de professores pelas políticas públicas, tanto em nível federal como estadual e municipal". Muitas portarias sobre a formação continuada e ensino a distância foram escritas pelo Ministério da Educação (MEC 2004; 2006; 2007) a fim de regular tal prática e garantir a qualificação dos formadores dos cursos.

Em 2003, o MEC, através da portaria ministerial n.1403, instituiu o Sistema Nacional de Certificação e Formação Continuada de Professores da Educação Básica, que gerou muitos debates por atrelar a formação a um exame nacional periódico para avaliar o desempenho dos professores.

Em documentos internacionais (Banco Mundial 1995, 1999, 2002; PREAL 2004; UNESCO 1998; Fórum Mundial 2000; Cúpula das Américas 2001) a formação continuada dos educadores é tratada com ênfase e a aposta no seu papel renovador é grande. Acreditam na formação para a "nova economia mundial" e aprofundam a discussão sobre as competências a serem desenvolvidas; sendo que a definição do que é ser competente é motivo de debates e discussões (Rios, 2001, 2002), pois apresenta uma grande polissemia.

Segundo Gatti (2009), em 2006, o Conselho Nacional de Educação aprova a resolução número 01 de 15/5/06, detalhando as exigências (tempos, temas, valores a serem pagos aos professores, incentivos, princípios, competências necessárias, disciplinas e conteúdos, áreas de atuação e etc) e trazendo com elas a preocupação com a qualificação a ser exigida dos formadores dos professores.

Começa uma nova discussão no discurso educacional nacional bem como nos discursos sistematizados a partir de congressos internacionais, ligando o perfil dos educadores ao perfil de seus formadores. Vaillant (2002) examinou, de 1990 a 2002, oitenta artigos e livros sobre formação docente e encontrou apenas cinco que discutem a formação dos formadores. Segundo Souza (2007, p.43) "observa-se de forma evidente a falta de políticas educacionais cujo foco central seja a formação de formadores”. Prada (2003) reitera o que afirma a autora e acrescenta que a formação dos formadores de professores precisa de mais atenção, pois o formador medeia a construção de conhecimentos dos profissionais e trabalha em conjunto com eles para ampliar a compreensão e apreensão de conceitos que orientem as 
práticas. $\mathrm{O}$ autor conclui que a formação de formadores precisa ser mais pesquisada a fim de que as necessidades dessa função e seus conteúdos sejam identificados com mais detalhamento.

A nova preocupação mobiliza discussões, mas ainda não foi incluída em termos de políticas nacionais. Em janeiro de 2009, o Decreto 6755 propõe organizar uma colaboração entre União, Estados e Municípios na formação inicial - básica (oferecendo inclusive cursos para titulação de quem já está na prática) e continuada dos professores desse ciclo, com a intenção de apoiar cursos, criar fóruns de apoio à formação docente, planos para diagnóstico, avaliação dos cursos e dos professores (para orientar a formação), bolsas de estudo e pesquisa. E também para orientar as ações que articulam as instituições de ensino superior que venham a ministrar tal formação com as escolas públicas que receberão a formação, mas nada é dirigido especificamente ao formador de educadores.

$\mathrm{Na}$ introdução ao tema feita até aqui, pudemos verificar como a formação continuada em serviço passou a ser tema de preocupação para, em seguida, ganhar um lugar de investimento e entrar para as práticas educacionais correntes. Ela passa a exercer diferentes propósitos e atender a diferentes expectativas, tais como: de ser um lugar de desenvolvimento profissional (pessoal ou a distância), de esperança no enfrentamento das mazelas educacionais, de veiculação de interesses políticos e ou privados, lugar compensatório ou para se obter titulação, lugar para se ganhar dinheiro ou para complementar o salário do professor, lugar de avaliação (e controle) das práticas.

\section{1 - Interesses e críticas}

Vamos percorrer agora o que dizem alguns discursos sobre interesses e críticas em torno da formação continuada em serviço.

André (2002) pesquisou dissertações e teses defendidas no Brasil na década de 1990 e encontrou 410 documentos que tinham entre suas palavras chave a formação de professores. Os documentos foram divididos em três temas: formação inicial, formação continuada e, por último, identidade e profissionalização docente. Os títulos que trataram da formação continuada somaram em geral, $17,8 \%$ da amostra coletada e dentro do título formação 
continuada, o tema análise de propostas de governo e de secretarias de educação (políticas de formação) aparece em primeiro lugar $(39,7 \%)$, mostrando o interesse em buscar o efeito das formações feitas no formato de políticas do governo.

O mesmo interesse temático foi encontrado por Lima (2001), que analisou treze trabalhos acadêmicos de mestrado e doutorado entre os anos de 1996-2000 e verificou que o objeto principal trabalhado foi o estudo de uma experiência ou de um programa específico de formação de professores. Dentro deste grupo destaca três subtemas: "acerca do contexto e das políticas e a regulamentação dos programas de formação contínua, a reconstituição das lutas da escola pública e os pressupostos da formação contínua”. (LIMA, ibidem, p.44). Fazendo parte deste item encontrou pesquisas que: "analisam a realidade profissional dos professores no contexto da política neoliberal" (idem, ibidem, p.47), sendo que um dos trabalhos enfocou o "processo de privatização das ações de formação contínua, bem como a reconstituição das lutas e resistências históricas da escola pública". (LIMA, 2001, p.47).

Vamos acompanhar agora alguns trabalhos de formação continuada e pública no Brasil, que foram objeto de análise em termos das aprendizagens produzidas e dos limites encontrados.

Gatti (2008), com o apoio da Fundação Carlos Chagas, salienta dois programas de destaque (considerados inovadores) na formação continuada implementados pelo primeiro setor, nos anos 1990: o PROCAP (programa de capacitação de professores dos anos iniciais, no Estado de Minas Gerais, na modalidade ensino a distância) e PEC (programa de educação continuada para professores, coordenadores, dirigentes regionais e técnicos do ensino fundamental, em sistema presencial, no Estado de São Paulo). Tais programas atenderam oitenta mil educadores (o primeiro) e noventa mil (o segundo). Ambos foram financiados pelo Banco Mundial. As pesquisas acerca dos mesmos (Duarte, 2004; Fundação Carlos Chagas 2002-2003, 2004-2007; Gatti, 2008), apontam as seguintes reflexões: a formação baseada em necessidades expressas pelos atores da própria rede, na qual houve negociação entre instituições formadoras (no caso instituições valorizadas como USP, UNESP, UNICAMP, PUC, entre outras) e unidades escolares, foi mais bem sucedida, já que os profissionais que receberiam a formação foram considerados sujeitos ativos (PEC). No PEC foram observados mais questionamentos acerca da formação e de seu formato, e isso ocorreu, segundo a autora, pelo incentivo à participação presente no programa. O PROCAP foi muito valorizado pelos 
professores nos seguintes quesitos: a formação foi incluída no calendário, ofereceu incentivo e contou com o compromisso das agências central e local.

Ambas as experiências são consideradas por Gatti (2008) como propostas que atenderam mais a formação inicial precária do que ao aprofundamento característico das formações continuadas.

Oliveira (2009, p.159) analisou em sua tese de mestrado o PEC municípios (programa de ensino a distância em parceria com universidades) e observou uma tensão quando o educador ocupou o lugar de aluno no curso de formação continuada: "recorrer às artimanhas de alunos para enfrentar as exigências do curso, afastando-se mais ou menos do que formalmente delas se espera". Para entender os motivos de parte deles não ter correspondido às expectativas dos docentes (pouca produção nas tarefas e com baixa qualidade), Oliveira lembra que muitos cursos de formação não levam em conta o estilo de vida dos professores que participarão da formação, pois muitos têm uma jornada intensa (dupla jornada na escola, uma terceira no curso de formação de noite e outra em casa nas tarefas domésticas), tendo que reduzir o tempo de sono e a qualidade de vida para dar conta de todas as demandas. Ele termina seu trabalho afirmando que alguns docentes conseguiram aproveitar a formação, ampliaram e aprofundaram seus saberes e o curso não teve para todos, segundo ele, uma função apenas compensatória. Ele lembra também que as escolas têm que ser melhoradas e não apenas os docentes individualmente; eles precisam ter boas condições de trabalho para poderem usar, inclusive, as aprendizagens recém-construídas na formação continuada.

Segundo outras pesquisas feitas pela Fundação Carlos Chagas (1993, 1999), analisadas por Gatti (2008, p.61), as avaliações externas feitas em programas de formação continuada a distância, em geral mostraram que:

De modo geral, notam-se melhores avaliações sobre as ações de educação continuada desenvolvidas sob os auspícios dos poderes públicos quando se trata de programas desenvolvidos em regiões com carências educacionais mais fortes, e encontram-se posturas menos entusiasmadas em regiões mais desenvolvidas socioeconomicamente e educacionalmente.

O ensino a distância coloca alunos com menos oportunidades em contato com discursos educacionais e isso causa entusiasmo. $\mathrm{O}$ que apareceu como positividade nas falas 
dos educadores contemplados nessas pesquisas foi: a oferta gratuita, o material impresso, bons vídeos e livros doados, ter tutores nos cursos, o contato com grandes nomes nas videoconferências, as trocas com seus pares e a motivação recebida. As evasões foram consideradas muito baixas. O que aparece como desvalorizado foi: aspectos infraestruturais, problemas com tutores (pouco acompanhamento e problemas de relacionamento), dificuldade na leitura dos textos, dificuldade de articular a teoria estudada com a prática.

A autora faz uma crítica em relação a tais formações: os pesquisados pouco falaram a respeito das mudanças e aprofundamentos produzidos de fato em suas práticas escolares.

Souza (2007, p.151) em sua pesquisa procurou compreender como alguns professores do município de Barueri (no caso do ensino da matemática) perceberam a formação que receberam do município e as transformações vividas e conclui que:

De modo geral, o desenvolvimento da pesquisa permitiu perceber que o desempenho do professor em sala de aula - em decorrência aos cursos de formação continuada - depende de um conjunto de fatores entre os quais estão: dar voz ao saber da experiência, ouvir o professor, pensar os cursos de formação em conjunto com os professores que participarão desse processo, cursos voltados à realidade do professor e do município - local onde atuam os docentes - e a formação dos profissionais que ministram os cursos (os formadores).

A pesquisa de Souza (2007) defende o protagonismo e o levar em conta a realidade do aluno, bem como o seu contexto de trabalho, o que foi encontrado também nas pesquisas de Gatti (2008) e Oliveira (2009). A insistência nesses pontos nos coloca a pensar nos termos opostos; sendo acadêmica e insistentemente combatidos: a passividade e/ou a dependência.

Nas pesquisas acima, ainda identificamos interesses em torno de encontrar a eficácia e a contribuição de algumas formações oferecidas pelo sistema público, e, apesar de partirem de enfoques e metodologias diferentes, produzem críticas e promovem discussões que exercem sua força na tentativa de alterar o rumo da formação em serviço. 


\section{2 - Preocupações acerca dos perfis: do educador, da formação e do formador}

Diversos estudiosos apresentam uma preocupação já conhecida por sua presença em relação à formação inicial e que também se mostra muito presente no universo das formações continuadas: os modismos que se apresentam, de tempos em tempos, como caminhos promissores para a solução dos males da educação e que são apropriados por diferentes correntes e gestões públicas. A partir deles alguns termos e conceitos passam a ser perseguidos e proibidos, outros valorizados e repetidos até serem legitimados como verdade. Como um exemplo dos termos proibidos, nos mostra Gatti (2008, p.63): "falar em domínio de técnicas para o trabalho docente e formação em tecnologias, ficou descartado sob o rótulo de tecnicismo, o qual adquiriu sentido ideologicamente pejorativo". Como um termo legitimado, de tanto ser repetido e "praticado", temos o construtivismo. Como analisa Carvalho (2001, p.125), ser construtivista passou ao senso comum nos discursos dos educadores, que independentemente de suas diferentes práticas e concepções sobre a função da escola, adotavam o termo: "Muitas vezes transformados em slogans e palavras de ordem, as máximas e os princípios didáticos construtivistas raramente ultrapassam fórmulas gerais de escasso valor prático para o trabalho do professor [...] como ater-se ao interesse dos alunos".

A idealização em cima de teorias ou conceitos, tal como ocorre nas "modas pedagógicas", implica na construção de saberes que são dispostos em oposição: de um lado os valorizados e de outros os combatidos. Os educadores são também divididos: os que criticam os modismos e os que seguem os modismos. Dentro deste último grupo estão os que citam constantemente os autores valorizados do momento, ficando no ciclo da repetição como podemos ver com Longarezi, Prada e Vieira (2010, p.14):

$\mathrm{Na}$ década de 80, ainda na forte tensão mundial pela guerra fria, alguns países europeus, principalmente a Espanha, fizeram suas reformas educativas, incorporando alguns pensamentos de autores norteamericanos pela tradução de algumas de suas obras, que depois foram importadas pela América Latina. Tais pensamentos estão sendo incorporados na academia, nas políticas educativas de países como Brasil há mais de 30 anos. Isso fica demonstrado quando os autores mais referenciados nos cinco anos (2003-2007), nos trabalhos apresentados na 
$\mathrm{ANPED}^{17}$ são norte-americanos e europeus, principalmente da Espanha, Portugal e Inglaterra. Porém, raramente aparecem os autores latinoamericanos, inclusive os brasileiros. Nesta ordem de idéias, observamos nos trabalhos apresentados na ANPED, e frequentemente nas dissertações e teses, que as referências aos autores são mais no sentido de amparo do pesquisador para suas idéias do que para aprofundar ou questionar os conceitos desses autores. Observamos também que as citações são mais um ciclo permanente de repetição dos pensamentos dos autores com os quais o pesquisador pode mostrar que concorda.

Outra questão que apareceu de maneira recorrente ao longo da revisão bibliográfica diz respeito à concepção da formação continuada em serviço. Tal discussão tem ocupado acadêmicos, teóricos, formadores de educadores, bem como os gestores das políticas públicas. A definição conceitual do trabalho implica em práticas diferentes, em descrições diversas sobre o perfil e a função do educador, o que modifica os rumos da sua formação e, por isso, motivo de tantos debates, experiências e pesquisas. Vamos conhecer o que dizem alguns autores que são estudiosos e referência na área, "lutando" pela construção de um professor reflexivo, pesquisador e transformador da realidade.

Pimenta (2002, p.26) defende que "conhecer significa trabalhar as informações. Ou seja: analisar, organizar, identificar suas fontes, estabelecer diferenças na produção da informação, contextualizar, relacionar as informações e a organização da sociedade, como são utilizadas para perpetuar a desigualdade social". Os professores são os protagonistas deste trabalho com os alunos, são eles que vão também trabalhar valores, o pensar criativo e as experiências de vida com os alunos. A mediação reflexiva do professor é ferramenta necessária na formação, que é definida por Pimenta (ibidem, p.38), como: "contínua, que tem o locus escolar e seus problemas como ponto de reflexão e análise das teorias”. E em outro momento Pimenta (1998, p.176) define como: "uma política de valorização do desenvolvimento pessoal-profissional dos professores e das instituições escolares, uma vez que supõe condições de trabalho propiciadoras da formação contínua dos professores, no local de trabalho, em redes de autoformação e em parceria com outras instituições de formação". A mediação reflexiva aparece como possibilidade de fazer o enfrentamento dos problemas da escola. A autora propõe que a formação reflexiva deve produzir um educador ativo e para isso 
a prática formativa deve propiciar o trabalho de desenvolvimento pessoal, organizando, portanto, as condições concretas de trabalho para que isso possa se dar.

Fusari e Rios (1995, p.38-39) apresentam orientações para uma política de formação articulando o conceito de educador - protagonista na transformação de sua prática e da sociedade, concreto, produzido por múltiplas determinações, trabalhador, portador de uma história profissional, com o de formação reflexiva - que deve relacionar escola com o mundo, discutir os problemas cotidianos, ter nas teorias um apoio para a atividade reflexiva em busca de um fazer competente:

- é preciso assumir que o educador brasileiro é um cidadão concreto, portanto uma síntese de múltiplas determinações, que trabalha para garantir seu sustento (e o de uma família, por vezes) e deve trabalhar também para a transformação da sociedade. Assim, sempre se deverá considerar o conjunto de fatores condicionantes - estruturais e conjunturais - que agem sobre sua prática, delimitando seu espaço real de possibilidades;

- é preciso considerar as deficiências do sistema formal de ensino pelo qual o educador passou, sem, contudo, pretender que a educação em serviço, por si só, recupere todas as lacunas e deficiências;

- é preciso encaminhar a educação do educador em serviço como um processo, no qual diferentes fases e meios estarão articulados, garantindo assim, uma continuidade do trabalho. Sempre se deverá considerar a relação entre o trabalho intraescolar e a consciência em relação à realidade social mais ampla;

- a identificação de necessidades de educação em serviço deverá ser encaminhada com a participação efetiva dos educadores, discutindo os problemas que enfrentam no cotidiano do seu trabalho;

- o processo de identificação de necessidades de educação em serviço deverá ser um momento de capacitação em si, superando o simples levantamento (oral e escrito) de problemas que os educadores enfrentam na prática;

- os problemas da prática dos educadores deverão ser considerados como ponto de partida e ponto de chegada do processo, garantindo-se uma reflexão com auxílio de fundamentação teórica que amplie a consciência do 
educador em relação aos problemas e que aponte caminhos para uma atuação competente.

Libâneo e Pimenta (1999, p.260) defendem a seguinte perspectiva de tratamento a ser dado aos educadores na formação: "considerá-los em sua capacidade de decidir e de rever suas práticas e as teorias que as informam, pelo confronto de suas ações cotidianas com as produções teóricas, pela pesquisa da prática e a produção de novos conhecimentos para a teoria e a prática de ensinar". E acreditam que transformar a escola é um desafio a ser enfrentado prioritariamente no campo das políticas públicas, por isso a importância do debate entre os setores envolvidos (escolas e seus atores, universidades etc.) fazendo pressão pela participação e protagonismo. Encontramos neste mesmo documento uma definição do perfil do professor:

Dizemos que o professor é um profissional do humano que: ajuda o desenvolvimento pessoal/intersubjetivo do aluno; um facilitador do acesso do aluno ao conhecimento (informador informado); um ser de cultura que domina de forma profunda sua área de especialidade (científica e pedagógica/educacional) e seus aportes para compreender o mundo; um analista crítico da sociedade, portanto, que nela intervém com sua atividade profissional; um membro de uma comunidade de profissionais, portanto, científica (que produz conhecimento sobre sua área) e social (LIBÂNEO e PIMENTA, 1999, p.262).

Novas qualificações se apresentam para falar do educador: humano, ser de cultura, apropriado dos saberes de sua área de atuação, membro de uma comunidade profissional. Outras características são repetidas: o educador protagonista, estudioso, questionador, ativo, mediador da formação e das informações, crítico, transformador.

Nóvoa (1992-a) valoriza os saberes do professor e suas histórias de vida (memorial), acredita que eles devem ser sujeitos de seu próprio desenvolvimento. A formação, para ele, não é a acumulação de cursos, é a possibilidade de construção e reconstrução das práticas, a partir da apropriação dos percursos feitos e a reflexão sobre os saberes produzidos. O autor lembra que muitos cursos de formação colocam o professor na posição mais baixa da ordem epistemológica: ser executor de programas pensados por especialistas, tornando o professor dependente dos mesmos - os que elaboraram e pensaram os programas. O autor diz que os 
professores recebem a nova formação a partir dos seus saberes da experiência, por isso precisam de espaços para lembrar, falar e fazer as articulações, para avaliar, escolher, selecionar, traduzir e incorporar. O autor entende a formação como o lugar onde se produz uma profissão, devendo usufruir saberes práticos e acadêmicos em sistema de parceria contemplando práticas de formação-ação e concomitantemente de formação-investigação.

Da concepção proposta por Nóvoa (ibidem), o protagonismo aparece novamente, e como novas qualidades encontramos o educador portador de histórias de vida, e negado como executor, dependente. A formação aparece como reflexão dos saberes produzidos, como formação-ação-investigação, com ênfase nos saberes produzidos nas experiências, o que já apareceu nas demais referências.

Segundo Collares et al., (1999), há os que reduzem a formação continuada à formação intelectual: dominar um conjunto de conhecimentos. Assim, os que oferecem a formação devem atualizar os educadores informando-os sobre descobertas científicas. Tal concepção desconsidera os saberes produzidos nas práticas e mantém a separação entre os que produzem (os cientistas, os acadêmicos) e os que utilizam os conhecimentos (os práticos). A formação oferecida desconhece a história dos saberes construídos por cada educador, ao considerar sempre o marco zero:

Zero se substitui o conhecimento obsoleto pelo novo conhecimento e recomeça-se o mesmo processo como se não houvesse história; zero porque o tempo transcorrido de exercício profissional parece nada ensinar. A cada ano letivo, uma nova turma, um novo livro didático, um novo caderno intacto. Zerado o tempo, esta-se condenado à eterna repetição, recomeçando sempre do marco inicial. (COLLARES, et al., 1999, p.211)

Os autores negam a formação como ação de dar informações intelectuais e informar novas descobertas científicas, a produção de separação entre os que produzem e os que usam os saberes. Mais uma vez, encontramos a defesa dos saberes produzidos nas práticas, enquanto o saber acadêmico continua sendo criticado e combatido..

Collares et al., (1999), defendem uma concepção na qual a formação é contínua, o que não significa ausência de rupturas e desordens, ou mesmo as alternâncias, pois o tempo da formação é um tempo de produção também de acasos, de acontecimentos não previsíveis e de 
experiências. Consideram que a política da descontinuidade quando praticada pelos governos é prejudicial, pois cria uma prática de interrupção dos projetos, de não escuta dos participantes, de alterações de programas e objetivos que iam bem, de rotatividade e burocratização, de pouco protagonismo, entre outras. A política que provoca descontinuidade atende aos planos de governo e não aos compromissos assumidos pelos profissionais: ela não se insere no desenvolvimento da instituição, não dialoga com seu percurso, por isso pode desmantelar experiências, desmanchar grupos de trabalho, cair em erros já conhecidos e criar novos que poderiam ser evitados se a avaliação dos profissionais da educação fosse considerada. As políticas da descontinuidade seguem o discurso da melhoria, como se nada estivesse sendo feito nesse sentido e mostram uma adoração ao conceito de inovação, que podem não significar uma transformação para melhor. Cada educador tem um lugar de enunciador que deve ser reconhecido e incentivado, cada um constrói uma representação sobre o que lhe acontece: "assumir o lugar de onde se fala é constituir-se como sujeito, múltiplo, polifônico e único em sua própria organização narrativa”. (COLLARES et al., 1999, p.213).

Encontramos a "política da descontinuidade", praticada pelos governos, como outro termo "atacado" no discurso acima por produzir educadores burocratas, dependentes, rotativos, além de desmantelar experiências que iam bem. Em afirmação, mais uma vez, o educador protagonista e ativo, capaz de ser enunciador e construtor de sua narrativa.

Collares e Moysés (1995) alertam para mais um problema a ser enfrentado na formação continuada de alguns educadores: a postura de desinteresse e desimplicação. Muitos professores não estão sensibilizados para trabalhar na sua parte e responsabilizam os poderes públicos de todas as dificuldades, aguardando com passividade as soluções externas, sendo que quando chegam, são recusadas com o discurso de terem um caráter autoritário (que podem ter ou não). Os autores valorizam a dimensão coletiva e a articulação entre a pesquisa, o estudo teórico e a discussão prática nos momentos de formação continuada em serviço. No perfil do educador, um perigo a ser combatido na formação através da valorização da dimensão coletiva: o desinteresse, a desimplicação, a passividade.

Lima (2001, p.32) caracteriza formação como: “Acredito que a formação contínua não se efetiva distanciada de um projeto de desenvolvimento profissional que a sustente, estando implícitos nisso, os sonhos, a vida e o trabalho do professor". E complementa: 
Dessa maneira, a formação contínua pode perpassar todas as instâncias da vida humana, carreando experiências que darão sentido à vida e ao trabalho do professor. Pode ser compreendida como uma atitude, um valor, constantemente presente de maneira articulada entre as experiências de vida e o pedagógico. O conhecimento a ela vinculado tem essa mesma abrangência mediadora da completude humana. No entanto, é a capacidade de carrear este conhecimento para a prática docente que caracteriza esse tipo de formação. Essa compreensão, porém, não minimiza a necessidade de políticas públicas de formação docente.

Compreendo que estar trabalhando em condições de dignidade constitui fator primordial para que o professor possa produzir e mudar qualitativa, individual e profissionalmente. Isto é um desafio para todos os professores, para as universidades, para os cursos de formação de professores, para os pesquisadores, para a sociedade, e para as políticas de valorização do magistério.

A formação contínua precisa ser reconhecida como um direito do professor, objetivando a realização de um trabalho de boa qualidade e em condições de dignidade. Essa questão não é apenas individual, é também social, pois envolve a ética (direção de sentido que damos ao exercício da profissão) e a autonomia (relativa ao projeto social da docência). Sendo um direito do professor, subentende-se que esse direito corresponda concomitantemente a um dever que precisa ser exercido. (LIMA, 2001, p.33).

Continuando com Lima (ibidem), vemos que o trabalho de formação tem uma dimensão transformadora e emancipatória quando prepara o professor para ser agente de transformação através da reflexão crítica, sendo também uma prática para a formação humana, ao mesmo tempo que profissional. Os projetos de formação dependem das condições objetivas e das forças em jogo na sua criação e implementação, o que quer dizer que muitos projetos inteligentes e criativos podem ser minados pelas lutas travadas (interesses capitalistas e quantitativos, por exemplo). As iniciativas de pesquisadores e docentes em manter o tema em discussão mostram-se como ações muito presentes e nesse sentido Lima (ibidem, p.167) propõe que a formação pode ser entendida conceitualmente como "o processo de articulação entre trabalho docente, o conhecimento e o desenvolvimento profissional do professor, como possibilidade de uma postura reflexiva dinamizada pela práxis”. Sendo que a reflexão é entendida como elemento de emancipação com intencionalidade declarada e é na ação que esse pensar torna-se agente de mudança. A formação pode propiciar a articulação entre o projeto pessoal, o pedagógico e o de sociedade, quando engloba a análise da prática, a reflexão teórico-prática e o trabalho docente (escola como ponto de partida e chegada). Para 
tanto, os professores precisam participar das decisões das Secretarias sobre as políticas e conteúdos da formação e precisam ter respeitados os seus projetos pessoais e de sua escola. Os tempos, os acessos, as condições financeiras devem ser pensados e equacionados também. Lima (2001, p.174) conclui: "no horizonte da utopia, está a formação contínua como um diálogo com a vida do professor a serviço da emancipação e como mediadora da função crítica, na luta por uma sociedade mais justa”.

Mais uma vez encontramos valorizados os aspectos pessoais do educador, compondo seus sonhos, seu desenvolvimento, direitos e deveres profissionais em busca de sentidos que dignifiquem a sua ação. As possibilidades desse profissional crítico, sensível, reflexivo, emancipado precisam ser reconhecidas e respeitadas pelos órgãos públicos, o que, mais uma vez, faz-nos pensar sobre o termo que essa definição coloca na oposição: o profissional técnico executor, passivo, não participativo, dependente, não crítico, que mantém o status quo.

A formação continuada defendida pelos autores que a entendem como uma tarefa reflexiva tem como característica oferecer oportunidades de pensar, de exercitar a crítica, o protagonismo e a participação, de estudo, de pesquisa, de retomar seu percurso pessoalprofissional, de discussão, de trocas de informações, de articulação entre teoria e prática, de sistematização, de análise de práticas para promover a ampliação e o aprofundamento de saberes em busca do aprimoramento, do desenvolvimento profissional e da transformação social.

Apresentados os perfis do educador e da formação, podemos nos interrogar sobre os discursos acerca dos perfis dos formadores dos educadores, que, como pudemos ver, começam a ser procurados.

Vaillant (2002, p.22) diz que: "os futuros formadores encontram-se diante de uma imprecisão de papéis ou funções. Pouco se conhece da figura do formador; seu papel não está definido; não existe uma construção prévia de um perfil para este 'novo' ator educativo". A autora propõe uma definição para o formador: uma pessoa dedicada e comprometida profissionalmente à formação em seus distintos níveis e modalidades. Um profissional capacitado e certificado para exercer sua função e que possui conhecimentos teóricos e práticos, capacidade e iniciativa para aprender e inovar, além de praticar os valores que pretende transmitir. 
Prada (2003) afirma que, dentro das redes públicas, fazendo a formação de seu corpo docente, estão os supervisores, diretores, coordenadores, orientadores, assistentes e professores. Podem participar da formação, porém, outros profissionais caso sejam contratados pelos gestores e administradores públicos. O autor revela quem são os profissionais que têm ocupado a função de formar educadores e há uma grande diversidade: intelectuais (professores e pesquisadores das universidades), especialistas (profissionais com alguma especialização, mestrado ou doutorado), práticos (que ministram oficinas, trocas de saberes etc.), técnicos (de saúde, por exemplo), profissionais liberais (advogados, psicanalistas, escritores e etc.) e políticos (que vão implementar projetos e programas), sendo que podem pertencer a diferentes áreas de conhecimento (educação, saúde, psicologia etc.).

Todos esses profissionais são atores que trazem especificidades e saberes à prática da formação continuada em serviço, caracterizando uma diversidade grande de discursos e orientações. Os estudos de Prada (2003) e especialmente de Vaillant (2002) mostram um interesse em delimitar tal variedade (tomada como algo negativo, perigoso) ao oferecer um mapa padronizando a sua formação: "além de conceituar e definir as competências e capacidades que deve possuir um formador que atua em um dispositivo de formação, é preciso definir, também, padrões para sua formação. Os padrões para a formação de formadores deveriam representar acordos sobre que coisas devem saber e ser capazes de fazer". (VAILLANT, 2002, p.33).

Prada (2003) defende um perfil para o formador: diz que não bastam os conhecimentos teóricos, os conhecimentos dos programas a serem implantados, os conhecimentos teórico-metodológicos da formação e os conhecimentos da experiência profissional. É necessário, também, saber conduzir a construção coletiva de conhecimentos, ter objetivos claros e declarados, fazer avançar as concepções e práticas da profissão, tendo no horizonte a contribuição à educação e à sociedade.

Vaillant (2002, p.14) diz que: "quando se trata do perfil que os docentes devem ter, é comum constatarem-se duas tendências. A primeira é uma supersimplificação: diz-se que deve saber e saber ensinar. A segunda é uma falta de hierarquização: apresentam-se grandes relações de qualidades e conhecimentos que os professores deveriam ter".

Prada (2003) constata que a formação dos formadores fica a cargo do próprio formador e Vaillant (2002) diz que a formação do formador é incentivada a partir de visitas a 
centros no exterior onde se desenvolvem atividades inovadoras de formação docente. Muitas destas visitas são financiadas por Universidades.

$\mathrm{Na}$ contramão dessa tendência de desenhar os perfis, encontramos os trabalhos de Pereira, M. (2002). Com ele vamos ser convidados a olhar para a formação dos perfis da perspectiva da crítica aos mesmos. Pereira, M. (2002) apresenta o tema da formação, analisado do lugar do professor: como alguém se torna professor? Como se é professor? Como é ser professor?

Diz Pereira, M. (2002): "Cada professor afeta e é afetado pela exposição aos acontecimentos e às relações de forças, que produzem movimentos, novos encontros de forças e isso se dá em dispositivos concretos (práticas e instituições)”. Para Pereira (ibidem, p.39): “A professoralidade é uma marca produzida no sujeito, ela é um estado, uma diferença na organização da prática subjetiva. Não é uma identidade: identidade é uma formação existencial modelada, retida em sua maneira de atualizar-se, a partir de uma caminho determinado e condicionante" e segue: "identidade é uma determinação, é uma redução das possibilidades de vir-a-ser, a um padrão que tende a se repetir" sendo que a "marca é um estado, uma diferença produzida na superfície de sua subjetividade” (PEREIRA, 2002, p.39). Pereira conclui que (2002, p.39): “Quando uma formação subjetiva é abalada por uma tensão desestruturante, depois de experimentar o caos das forças interferentes, ela se organiza em uma nova formação". Segundo o autor, as práticas institucionais que formam os professores podem ser mais ou menos violentas na prescrição das expectativas relacionais: propõem, convidam, seduzem, impõem, controlam, punem, premiam e assim por diante.

Por isso não faz sentido, para o autor, perguntar o que é ser professor, pois a resposta levaria a criação de um perfil ideal e identitário e não a uma subjetividade possível dentro de um jogo de relações e de forças, nas quais as técnicas de si atuam, criando modos de ser professor. É nas tramas das forças em jogo que busca compreender os modos de constituir-se como professor: algo sempre passível de deixar de ser o que cada professor vem sendo, para tornar-se diferente de si mesmo (configurar e desfigurar). O sujeito nesse sentido é "prenhe de devires" (PEREIRA, 2002, p.36).

Na perspectiva acima encontramos outra posição em relação aos perfis que vinham sendo delineados até então: eles devem ser "evitados" para que cada profissional possa inventar-se a partir dos jogos de força de seu campo de atuação. Se ainda assim tentarmos 
procurar uma qualificação ao educador e seu formador, a partir do discurso do autor, encontraremos a liberdade e a inventividade como marcas procuradas e valorizadas. Com relação à qualificação da formação podemos dizer que a mesma deveria se constituir como uma prática de si na qual os formadores pusessem o educador no exercício de falar de si e dos jogos de força vividos em torno da sua definição profissional, sendo uma experiência "desestruturante", um mergulho no "caos das forças inferentes" (PEREIRA, 2002, p.39), para assim propiciar novos arranjos identitários.

Escutar os discursos sobre a formação continuada de professores (com um foco no serviço público e em serviço) foi um exercício de colocar a falar as expectativas, os interesses, as preocupações e com eles as representações acerca das identidades necessárias (ou não), dando destaque ao que combatiam e ao que negavam nessa relação. Os saberes valorizados e os recusados também apareceram. As verdades sobre o melhor caminho da formação foram sendo deslocadas no tempo histórico, fixadas ou movimentadas em termos de lei. O discurso hegemônico nas pesquisas analisadas apareceu em defesa do professor pesquisador e reflexivo e do formador "profissional" (que toma a tarefa como o seu compromisso e a sua identidade).

A composição construída neste capítulo apresenta um cenário complexo, uma multiplicidade de forças que pressionam para certas direções e outras tantas que fazem o vetor contrário, a resistência.

Vamos agora dar mais um último ajuste em nosso zoom e analisar como alguns trabalhos apresentam a formação continuada em serviço nas gestões municipais da prefeitura de São Paulo ${ }^{18}$, aproximando-nos do campo e do tempo no qual a presente pesquisa se situa. Nosso foco a partir de agora será: buscar nos discursos de alguns educadores, formadores e pesquisadores as expectativas e atribuições em torno da política educacional municipal.

\section{3 - Expectativas em torno das políticas públicas municipais de São Paulo}

Como vimos até agora, a formação continuada em serviço tem um histórico atrelado à construção da profissão docente. Nasce, portanto, como política pública no Brasil, das 
dificuldades da formação inicial e dos problemas enfrentados pelas escolas públicas, e luta para se consolidar como uma prática de desenvolvimento e emancipação profissional.

Ao longo dos discursos sobre a formação continuada em serviço encontramos muitos perfis para o educador e seu formador sendo buscados e produzidos através das práticas formativas. Os discursos apresentam os saberes valorizados como os melhores para: construir o perfil esperado para o educador (aquele capaz de fazer face aos desafios de cada etapa) e construir a formação mais efetiva - aquela que consegue atingir os objetivos eleitos (que se modificam em cada momento histórico).

Entre as expectativas da formação tal como cada uma foi pensada, proposta e efetivada e os resultados, encontramos práticas avaliativas realizadas em pesquisas acadêmicas e/ou em órgãos públicos. As avaliações são usadas como diagnósticos e funcionam como base para criação de novas políticas públicas. Os personagens que entram em cena e se rodiziam na tarefa de desenhar os caminhos da formação pública elegem os saberes, os métodos de trabalho e indicam responsabilidades pelos problemas encontrados nas avaliações. As "faltas" e as responsabilizações são distribuídas e a formação continuada em serviço é colocada como um lugar de fazer frente aos problemas apontados.

A partir de agora, veremos como, através das formulações, são criados lugares e atribuições às políticas educacionais no sentido do que elas foram-fizeram e deveriam ou não deveriam ser e fazer.

Começaremos com algumas vozes que discutem o lugar geral das políticas (educacionais) públicas no Brasil e depois as que discutem políticas concretas no município de São Paulo.

O estudo de Souza (2006) afirma que as deficiências da formação dos professores são um fato, como atestam tantas avaliações e pesquisas, o que não significa que os professores devam ser responsabilizados isoladamente pelos obstáculos da educação, nem pelo fracasso escolar dos alunos a partir do argumento da incompetência ou ineficiência. A autora afirma que o foco de atenção das políticas educacionais deve ser a escola e seu projeto: melhorando as "condições concretas de trabalho nas escolas, as relações interpessoais entre os vários agentes escolares, a cultura escolar e a formação do educador" (SOUZA, 2006, p.490). A autora propõe uma torção da responsabilização do professor em direção ao projeto da escola e suas condições concretas de funcionamento. As políticas educacionais aparecem em um lugar 
que precisa ser ajustado, pois têm o poder de responsabilizar individualmente e deveriam dar condições aos projetos das escolas.

Rossi (2001) apresenta outro aspecto que acredita ser o que falta à escola pública: politizar-se. Segundo a autora "as bases do procedimento político, são entendidas como a organização da esfera pública na qual as pessoas ampliam sua comunicação, articulam suas opiniões e se unem para alcançar objetivos coletivos e interesses comuns" (ROSSI, 2001, p. 95). A autora diz que no cenário atual as políticas públicas tentam responder aos desafios com o discurso da "privatização": defendem a descentralização, a participação das famílias na gestão e dos cidadãos da comunidade através da ajuda voluntária. A proposta de gestão das escolas é inspirada em empresas do setor privado e pode desenvolver uma despolitização das práticas e ferir o protagonismo da Federação (Estado e Municípios) e a sua responsabilidade na garantia do serviço educacional de boa qualidade para todos, interferindo inclusive no poder decisório e atribuição de recursos. Diz a autora:

As demandas participativas do Banco Mundial e da nova LDB estão mais atreladas à concepção tecnocrata, que define autonomia como autogestão na produção e como modelo de gestão descentralizada para vencer a crise da centralização burocrática, com o planejamento "democrático" da participação dos executantes. Trata-se da prática de cogestão com controle remoto, com autonomia administrativa/pedagógica outorgada e controlada, com descentralização de decisões circunscritas ao nível técnico-operacional. Trata-se de uma alternativa moderna de despolitizar o sistema, inserindo a participação de professores, pais, alunos e comunidade locais no processo que se diz neutro. No entanto, é uma prática decorrente de nova estrutura de poder comandada pelos maiores grupos econômicos, operando em bases supranacionais para reinvindicar instituições, privatizá-las e ampliar o consumo em escala mundial. (ROSSI, 2001, p.100).

O discurso de Rossi (2001) responsabiliza a política que é apontada como "o caminho" para a mudança, mas não qualquer política. Seu foco é mais a política geral do que a educacional. Com um discurso político partidário, desqualifica seu opositor: a "política supranacional, incentivadora do consumo, tecnocrata, privatizadora, despolitizadora" (ROSSI, 2001, p.100). Entre o que ataca e o que defende, a política se mostra soberana nos holofotes do discurso. A política no discurso desta autora aparece como o que falta, mas o que falta é um tipo de política definida como organização pública, participação em torno de objetivos e 
interesses comuns. Essa política que falta poderia resolver os problemas da escola. Em oposição a essa política que falta, há uma política que é presente e que é negativada e responsabilizada pelos problemas da escola: a política tecnocrata.

Com Jacobi (2003) podemos pensar na questão da participação nas políticas educacionais pela perspectiva de uma prática concreta que une educadores e comunidade: os conselhos de escola. O autor pesquisou nos conselhos, durante a gestão de Erundina no município de São Paulo, os alcances e limites da descentralização alcançada na política pública educacional em relação à dimensão participativa dos participantes dos conselhos.

A gestão da cidade exercitada pela prefeita no período é apresentada pelo autor como tendo objetivos claros de democratizar a gestão pública e o acesso às informações, potencializar espaços de participação e incluir a população nas decisões e escolhas. Com um discurso militante e teórico, o autor defende a descentralização e os ideais participativos:

Onde quer que se promova a descentralização se invoca sua capacidade de gerar participação social. A propagação em direção às bases de poderes, competências, responsabilidades, recursos financeiros e técnicas abre espaço para a articulação mais direta e democrática entre gestão pública das instituições do Estado e as práticas de participação e organização citadina. [...] É importante ressaltar que quando se fala em participação se explicita uma potencial ruptura com a distância quase sempre existente entre o poder centralizado e as realidades sociais mutantes e heterogêneas que põem em evidencia os limites dos mecanismos formais, verticais, corporativos e clientelistas. [...] É necessário, entretanto, que da sociedade civil surjam interlocutores coletivos, grupos comunitários, movimentos sociais que tornem possível uma participação ativa e representativa. [...] Os segmentos populares são os que mais necessitam da institucionalização da participação, na medida em que o direito se configura como poder dos pobres ${ }^{19}$ e a possibilidade de benefícios para os que sofrem desigualdade. (JACOBI, 2003, p.130).

19

Em nosso trabalho tomamos uma definição de poder diferente em relação ao autor ora citado; a partir de Foucault, o poder é entendido como presente em todas as relações, como exercício e ação de uns sobre os outros, o que será mais bem trabalhado no capítulo seguinte. Nosso interesse em trazer a voz deste autor é verificar a que se pode chegar, a partir da análise do discurso do mesmo, em termos da posição e expectativas atribuídas à política. 
$\mathrm{Na}$ experiência concreta com os conselhos ${ }^{20}$, porém, o autor se deparou com obstáculos que atrapalharam a construção de uma prática pautada nos objetivos defendidos acima: as dificuldades em fazer com que os que são chamados a participar venham, permaneçam e contribuam de fato para o debate e para a procura de soluções aos problemas das escolas. Esmiuçando as dificuldades o autor as enumera: o uso do conselho para legitimar causas pessoais, a incapacidade de organização das escolas, incorporar o processo decisório dos conselhos na política educacional, entraves na legislação, a falta de tradição em participação política através de conselhos no Brasil, construir a noção de escola como equipamento social, acolher demandas e encaminhar trabalhos, estimular a corresponsabilização na gestão, a não aceitação da comunidade de educadores (professores, orientadores, coordenadores, diretores e etc.) da interação com representantes da comunidade (pais e alunos), a resistência em dividir as informações e descentralização das decisões, a pouca disposição de trabalhar democraticamente, a dificuldade do grupo do conselho em gerenciar o dinheiro público, a distância geográfica e o horário das reuniões, entre outras.

Entre o que se idealizou politicamente e o que se produziu nas práticas houve uma grande distância, um choque nas expectativas iniciais, sendo que a atuação política da comunidade foi considerada insuficiente para a experiência de participação proposta.

Os resultados dos Conselhos, segundo pesquisa de Jacobi (2003), foram heterogêneos, mas iniciaram um movimento novo na cidade, estimulando a participação crítica, a intervenção popular nas decisões e o desenvolvimento pessoal como cidadão de quem participou. A positividade do que foi possível produzir pôde ser encontrada no movimento iniciado de participação.

Zanzini (2000, p.29) parece concordar:

As estruturas de organização nas escolas sofreram significativas transformações a partir da decisão que proporcionou poder deliberativo aos Conselhos de Escola; onde pais, alunos, professores, especialistas, merendeiras, vigias, puderam se reunir para discutir num espaço coletivo, os

20 A estrutura montada segundo Jacobi (2003) foi: um conselho em cada escola, no qual toda a comunidade escolar teve garantida a possibilidade de participar e tomar decisões respeitando as diretrizes municipais, um colegiado de representantes dos conselhos (CRECES), que traduzia em prioridade orçamentária as propostas dos conselhos. 
problemas da escola, e assim, experimentar uma nova forma de produzir conhecimentos e exercer a cidadania.

O que se desenha em termos das políticas públicas é uma demanda de participação e escolha no poder de deliberar, o que é definido também como o exercício mais difícil, o maior obstáculo.

Souza (2005) pesquisou a formação em serviço de professores (do ensino fundamental) no município de São Paulo de 1956 a 2004, procurando desafios e transformações. A autora levou em consideração a experiência pessoal dela como educadora municipal, o que permeou toda a sua produção. Zuchetto (2001) também pesquisou a formação dos educadores no município de São Paulo, mas entre os anos 1983-1997. Ela buscou as ações de formação contempladas nas políticas educacionais das prefeituras. Zanzini (2000) pesquisou uma experiência de formação continuada em grupos de formação, na gestão da prefeita Erundina (1989-1992), e analisou também algumas políticas públicas em períodos adjacentes.

Destacamos destes trabalhos algumas de suas conclusões sobre as tendências políticas e a relação com o tipo de gestão educacional e formação constituída.

Mário Covas (1983-1985) é apresentado por Souza (2005) como um grande defensor da abertura democrática e, como prefeito da cidade de São Paulo, trabalhou em defesa da formação continuada com convênios com boas Universidades. Incentivou a formação em serviço com a regulamentação e pagamento da hora atividade (tempo de estudo e planejamento docente), sendo que o investimento em formação ainda se deu de forma intensa aos ingressantes da rede. Covas seguiu, segundo a autora, uma tendência muito valorizada pelos educadores e Universidades na época: a pedagogia crítico-social dos conteúdos de Demerval Saviani.

Zuchetto (2001, p.27) concorda:

Após vinte anos de governo autoritário, em que a Aliança Renovadora Nacional (Arena) ocupou todos os cargos políticos e administrativos, um partido de oposição, o Partido do Movimento Democrático Brasileiro (PMDB) chegou ao poder por eleições diretas para governar o estado de São Paulo. O partido defendeu durante a campanha eleitoral as diretrizes de "participação" e "descentralização". Franco Montoro, governador eleito, designou Mário Covas para administrar a capital. Com o novo prefeito, em 1983, assume a Secretaria Municipal de Educação a professora Guiomar 
Namo de Mello, educadora e militante política, que traz em seu projeto educacional um programa com propostas claras para discussão e constantes diálogos sobre a educação.

Com relação à formação, a autora faz referência aos mesmos avanços apontados por Souza e acrescenta que a administração manteve o diálogo com a escola antes de tomar as decisões sobre a formação, propondo um trabalho mais de acordo com as necessidades e expectativas senão dos professores, ao menos de seus formadores.

Da relação entre política educacional e formação nesse período relatado esperou-se abertura, participação, discussão, diálogo e incentivos concretos de viabilidade. A gestão é apresentada através de termos considerados positivos: incentivou, trabalhou em defesa, pagou, fez convênios com boas Universidades, abertura democrática, trouxe concepção valorizada de forma intensa.

Sobre o período político do prefeito Jânio Quadros (1986-1988), Souza (2005) fala do tratamento truculento dado ao funcionalismo (demitiu e puniu grevistas), da centralização das decisões, da gestão inspirada nos governos militares (sem transparência), e destaca o fato de terem recolhido todo o material pedagógico anterior elaborado pela equipe do prefeito Mário Covas e que era considerado muito interessante pelos profissionais da rede. No período de Jânio a formação continuada era optativa e feita fora do período de trabalho.

Zuchetto (2001, p.33) descreve o ministro de educação convidado por Jânio, o jornalista Paulo Zingg, como: "participante do movimento de 1964 e colaborador de outras campanhas políticas do governo autoritário". O trabalho feito é descrito como o de apagar o trabalho da gestão anterior e um verdadeiro "caça às bruxas".

$\mathrm{Na}$ formação organizada para diretores, o tema foi legislação e procedimentos. A formação dos coordenadores foi descrita do seguinte modo: "foram preparados para exercerem a função de multiplicadores e medidores das relações entre o sistema municipal e o professor, agindo como transmissores e fiscalizadores da implementação dos pacotes" (ZUCHETTO, 2001, p.35). A formação para professores foi feita para a área profissionalizante, com cursos de curta duração e temas técnicos tais como: serviços gerais de escritório, serviços bancários, entre outros.

Os verbos usados para descrever essa gestão foram: recolher, interromper, paralisar, perseguir, intimidar, fiscalizar, achatar, demitir, caçar (as bruxas), punir, centralizar. Os 
termos recorrentes encontrados para o educador-formador foram: multiplicador, medidor, transmissor, fiscalizador, implementador.

Souza (2005) destaca alguns diferenciais que viu acontecer na gestão educacional da prefeita Erundina (1989-1992) e que valorizou muito a partir do seu lugar de funcionária municipal: a proposta da descentralização da administração e o fortalecimento da regionalidade administrativa para atendimento das necessidades locais, bem como o incentivo à participação através do fortalecimento dos conselhos, fóruns, plenárias, grêmios etc. Erundina, segundo a autora, foi eleita num clima de muita expectativa no meio educacional em torno da reversão do quadro deixado por Jânio na educação: além de mulher e assistente social, tinha uma formação política socialista e representava a oposição ao sistema econômico e social dominante. Além de todos os aspectos acima, convidou para ser seu secretário um "ícone” da educação popular, o educador conhecido mundialmente: Paulo Freire.

A formação foi descrita como construída a partir do diálogo permanente com a comunidade. Houve apoio político aos professores demitidos ou punidos por Jânio, bem como gratificação para professores que trabalhavam em áreas de difícil acesso. Restaurou o regimento banido pela gestão anterior e nele, os conselhos deliberativos. Com relação à formação continuada em serviço, criou a jornada ampliada que previa tempo de trabalho coletivo, reflexão e estudo sobre a prática. Trouxe nova organização curricular para ser discutida (introduzindo a noção de educação política). O compromisso foi com o fim da exclusão educacional e social, e a favor do protagonismo e da autonomia das escolas.

Zuchetto (2001) concorda e acrescenta que a formação continuada em serviço recebeu uma carta de seis princípios, na qual os lugares dos educadores e seus formadores são definidos, dando um caminho também para a formação. Parcerias com universidades e convênios com movimentos populares são citados, bem como incentivos de horas de trabalho extraclasse pagas para a formação. Muitos são os projetos de formação listados. Zanzini (2000) apresenta a concepção da formação permanente do período centrada na escola, através da ação-reflexão-ação (que parte da prática e a ela retorna, busca na teoria um embasamento do seu pensar-fazer e vivencia uma metodologia do diálogo e da convivência no grupo).

Os verbos que aparecem com recorrência na descrição da formação nessa gestão são: pensar, refletir, agir, vivenciar, experimentar, incentivar, discutir, descentralizar, fortalecer, dialogar, participar, retomar, reverter (quadro ruim), atender. 
As autoras citadas concordam que um grande diferencial dessa gestão na área da formação continuada em serviço foi a experiência com os grupos de formação propostos por Paulo Freire ${ }^{21}$. Introduzimos nesse ponto mais um autor que produziu um trabalho de grande fôlego sobre os grupos de formação: Lucas (1992).

Lucas (1992) encontrou no formato desses grupos o material para pensar como se dava a relação entre teoria e prática tecida pelos educadores. Ele analisou todo o material oficial propositivo dos grupos e acompanhou 17 grupos de formação de uma região de São Paulo. O autor apresenta os grupos como uma das modalidades do programa e uma das principais frentes de trabalho de formação de educadores da Secretaria Municipal de Educação (SME). Tal prática foi considerada básica e prioritária para viabilizar a proposta política da gestão como um todo. A formação continuada em serviço é posicionada como elemento constituidor da prática da escola pública democrática que se faz e refaz. Os proponentes dos grupos contaram em grande medida com o apoio de universidades para a discussão teórica, levantamento de pesquisas em torno do tema da reorientação curricular e da construção do projeto político pedagógico das escolas.

Chamam a atenção do autor, no sentido do que ele constatou e valorizou, os seguintes aspectos da formação em grupo: a forma coletiva de construção dos encontros, a valorização do professor: "recuperava a energia criativa e a vitalidade de sua prática" (LUCAS, 1992, p.68), o resgate da experiência educacional como fato político no sentido de tomada de posição, eleição de prioridades e atitude de escolha, a discussão de concepções sobre educação popular e sobre a própria experiência em curso de formação do educador - sempre problematizada, o estudo a partir da problematização da prática, a clareza quanto ao perfil do professor a ser construído em tais práticas formativas, o resgate da dimensão da afetividade nas relações. Ele observou também que tal experiência ajudou a romper com as formas tradicionais de formação docente, chamadas por ele de cursismo: "prática presente e hegemônica nas redes públicas e à qual os professores estão acostumados", mantendo-se e passivos e sem enfrentar grandes conflitos (LUCAS, 1992, p.177). O autor viu confundiremse os lugares do educador com o do militante partidário: "é preciso tomar cuidado para que o

21 O primeiro motivo de trazermos a experiência dos grupos de formação para esta análise é o fato dela aparecer repetidamente citada ou trabalhada na bibliografia encontrada e constar em vários trabalhos acadêmicos (Mussi, 2000; Zanzini, 2000); o segundo é que a experiência desta pesquisadora com formação continuada de educadores partiu deste referencial conceitual e prático. 
pedagógico não seja absorvido, apropriado e esvaziado no político partidário" (Idem, ibidem, p.221).

As valorizações colhidas através da voz dos participantes e que mais apareceram nos questionários foram: maior satisfação com o trabalho, maior segurança, ajudou a fazer escolhas mais democráticas e participativas, acesso a conhecimentos novos, aulas planejadas melhoraram e o interesse dos alunos também, conseguiram solucionar problemas da prática, construíram maior embasamento e consistência teórica, aumento da motivação e melhoria dos vínculos, capacidade de criação, melhorou o ensinar (superação de práticas antigas e ineficientes) e a prática da avaliação foi mais formativa, a relação com os alunos e pais foi melhor investigada, alcançaram um patamar mais crítico, fizeram mais questionamentos, desacomodaram-se, indignaram-se mais, provocaram mais mudanças em suas escolas de origem e sentiram-se cidadãos melhores, alcançaram maior clareza do seu papel e da sua opção teórica e identitária com relação ao seu lugar profissional.

No desenho das características do educador que recebeu a formação, encontramos: vitalidade (satisfeito, seguro de sua identidade), democrático e participativo, consciente e crítico, cidadão, inquieto-inquietude, problematizador, afetivo, ativo, portador de mais saberes, criativo e potente (capaz de melhorias na prática pessoal, nas práticas de sua escola e no vínculo com os alunos).

As dificuldades vividas colhidas tanto pela voz dos participantes como de quem coordenou os grupos foram: bloqueio na escrita, ansiedade em expor sua prática, insegurança teórica, uso do senso comum, presença de ideologia não compatível com o processo, ser protagonista dos caminhos escolhidos pelo grupo e responsável por sua produção, a presença ativa, ser cobrado pelas faltas ou por não fazer as tarefas combinadas, a relação ruim estabelecida com alguns coordenadores de grupo (apontaram o desinteresse, o despreparo, a falta de planejamento e envolvimento com a proposta), a desconfiança dos colegas ("posso mesmo falar o que penso nos grupos?”), as expectativas por respostas mágicas, o lidar com a incerteza.

A partir das dificuldades trazidas pelos educadores pesquisados um novo desenho para compor as características do educador que recebeu a formação: desconfiados, ansiosos, inseguros. 
Lucas (1992, p.183) levanta uma tensão vivida em todos os grupos que observou: “o profundo respeito pelas convicções de cada um e a necessidade do questionamento dessas convicções". Essa foi uma problemática difícil de ser enfrentada e levou muitos educadores à desistência, segundo depoimentos que recebeu. Outra tensão recorrente, descrita como um obstáculo a ser transposto pela formação, mas que muitas vezes também levou à desistência foi em relação às resistências atribuídas aos participantes: "a presença de resistências, de crenças em determinadas práticas que emperram a efetivação da mudança" (LUCAS, 1992, p.181). Ou: "professores muito resistentes acabam desistindo do grupo para não terem que ouvir o que não acreditam ou o que incomoda" (Idem, ibidem, p.183) ou por não quererem viver conflitos. Neste caso os professores são responsabilizados individualmente pelas dificuldades e conflitos e a resistência passa a ser uma nomeação que caracteriza e divide: o grupo dos resistentes, o grupo dos que permanecem e participam.

Há dentro do grupo dos resistentes, um tipo diferente: os inseguros. Essa nomeação do pesquisador foi encontrada também nas falas dos educadores quando convidados a falar de si nas experiências dos grupos. Lucas (1992, p.181) diz que tal grupo, frente à pressão dos grupos de formação por mudanças e a pressão de diretores, coordenadores, colegas e pais tradicionais e autoritários, os professores "ficam inseguros e tendem ao recuo". Para esse grupo, a responsabilidade individual é amenizada, tal posição de insegurança e recuo é produto das pressões sofridas.

Com o levantamento do autor sobre as tensões e as dificuldades ao longo da experiência dos grupos, temos, a partir dos trechos destacados acima, novos lugares que também caracterizam o educador: resistente-evitador de conflito e mudança, resistenteinseguro, ansioso, desconfiado, dificuldade de estudar, escrever e lidar com a incerteza (desejo por soluções mágicas), desapropriado da teoria, passivo, descompromissado, alienado, bloqueado.

O discurso da pesquisa encaminha críticas e termina por apontar novos caminhos a serem trilhados ou evitados. O lugar do educador almejado (como sendo um profissional capaz de relacionar teoria e prática), a partir da formação nos grupos, é questionado, entendido ainda como insuficiente. A insuficiência "poderia ser trabalhada", segundo o autor, caso a política de formação pudesse incorporar esse interesse em suas práticas. 
Souza (2005) alega que a gestão de Maluf (1993-1996) deu prioridade a obras em detrimento à educação, retornado junto com a nomenclatura Delegacia de Ensino a concepção autoritária e tradicional da educação. O prefeito teria verticalizado as relações distribuindo poderes decisórios aos cargos mais altos, e tendo investido pouco na formação continuada dos educadores; quando o fez, foi através de cursos e oficinas temáticas como sexualidade, drogas, entre outros (o que foi apresentado pela autora como algo negativo, incorreto enquanto escolha). O secretário da educação fez algumas tentativas de formação e valorização do professor e da escola pública, mas que pouco frutificaram.

Zanzini (2000, p.30) traz alguns dados na mesma direção da autora acima: "A administração de Paulo Maluf e a de seu sucessor, o seu ex-secretário de finanças, Celso Pitta, descumprindo a Lei Orgânica do Município, deixaram de aplicar mais de setecentos milhões de reais de 1995 a 1997 na educação municipal”. A autora descreve e critica o movimento chamado por ela de "privatização" do sistema educacional, que levou à votação propostas de terceirização da gestão das escolas, bem como parcerias feitas com Faculdades de Administração, Pedagogia, Economia e Engenharia de produção para modernizar a gestão escolar. A eleição de especialistas destas áreas de conhecimento para ocupar cargos de chefia também é apontada como um equívoco. Os funcionários que receberam formação foram prioritariamente os delegados de ensino, os supervisores e os diretores, sendo que o modelo empresarial adotado foi o Total Quality Control ${ }^{22}$. Tal proposta foi inviabilizada por falta de adesão dos educadores que saíam de uma gestão participativa inspirada nas ideias freireanas. A resistência ao modelo burocrático, funcionalista, empresarial e competitivo foi possível, segundo a autora, pelo "pensamento contra-hegemônico que foi construído durante a gestão de Paulo Freire" (ZANZINI, 2000, p.33), secretário da educação na gestão Erundina (19891992).

Procuramos, acima, utilizar termos encontrados repetidamente no texto das autoras, quando descreviam e analisavam a gestão de Maluf, como: menos, pouco, quando o fez foi, fez algumas tentativas, mas que pouco, deixaram de, falta de. O que mostra a insuficiência. Por outro lado outros termos são apresentados na valorização negativa que receberam:

22 A Filosofia da Qualidade Total é uma técnica empresarial muito combatida por educadores críticos e que foi adaptada para o contexto escolar na busca por melhorias e redução de custos, e; enfocou a produtividade. Para saber mais ver: LONGO, R.M.J. A qualidade total começa e termina com educação: — Brasília: IPEA, 1995 (RI IPEA/DPS, n.6/95). 
delegado de ensino, verticalização das relações, poder decisório a cargos mais altos, oficina temática, privatização, terceirização, empresarial.

Na gestão Pitta (mesmo partido político de Maluf), Souza (2005) diz que houve a mesma ênfase da gestão anterior, porém, foi uma gestão que sofreu mais descontinuidades em função das trocas constantes dos secretários de educação, que foram quatro no período, gerando, muitas vezes, mudanças conceituais dentro do programa educacional de uma mesma gestão. Tentativas de formação e parcerias com Universidades foram feitas. Souza (2005) destaca a experiência do GAP (grupo de apoio pedagógico), que levantou demandas de formação junto às unidades, eram afetivos (seguiam uma linha de fazer vínculos o que era percebido pelas grandes mesas de lanche oferecidas para conversas nas pausas entre os trabalhos) e não trabalhou na linha do controle de muitos supervisores, o que acabou por criar rivalidades com os supervisores, que acabaram por proibir a continuidade dos GAP. Em 1999, segundo a autora, o DOT foi dividido em núcleos, um deles somente para pensar e investir na formação continuada, chamada de reciclagem (esse termo é apresentado pela autora como algo pejorativo: ela diz que se recicla lixo e não pessoas). Em 2000, as Universidades FE-USP e PUC foram chamadas para contribuir na escrita dos projetos pedagógicos das escolas e trouxeram de volta a concepção freireana do professor reflexivo (exercitada na gestão de Erundina e valorizada pela autora).

É possível notificar positividades somente em relação à gestão de Pitta e foram apresentadas através das seguintes construções discursivas: houve a tentativa de fazer formação em parceria com Universidades; um núcleo do DOT foi designado só para pensar e investir na formação; Universidades foram chamadas para contribuir na escrita dos projetos pedagógicos das escolas e trouxeram de volta a concepção freireana; criou o grupo GAP que não trabalhou na linha do controle e levantou demandas das unidades. Percebemos como a Universidade é valorizada como parceira na formação, como a demanda de participação é mais uma vez confirmada, bem como a concepção reflexiva do educador. Aparece um elemento novo valorizado: o afeto.

Governos mais autoritários, situados pelas autoras nas gestões municipais de Jânio (1986-1988), Maluf (1993-1996) e Pitta (1997-2000) deram à formação, segundo as autoras, um enfoque mais instrumental: o formador aplicava a formação que foi pensada por especialistas. Foi atribuído ao formador comum o lugar de executor, com pouca autonomia intelectual, e o professor foi tratado e descrito como um profissional ora insurgente 
precisando ser controlado, ora acomodado, precisando de direção. As práticas formativas, quando aconteceram, foram treinos técnicos. Tais práticas deixaram o professor no lugar de consumidor de saberes definidos pelas políticas públicas como os melhores.

A gestão da prefeita Marta Suplicy (2001-2004) é retratada por Souza (2005) como o governo da reconstrução da cidade como cidade educadora. A qualidade da educação foi pensada como qualidade social, retomando diretrizes da gestão de Erundina (mesmo partido político): democratização e descentralização da gestão - democratização do acesso - garantia da permanência na escola.

$\mathrm{Na}$ formação continuada em serviço trabalhou com projetos de longa duração e as formações foram chamadas de "permanentes", como: Profa, Vivências Culturais, Mão na Massa, Círculo de Leitura, entre outros. Nos encontros de formação havia representatividade e muitos foram os grupos de trabalho: as reuniões de pólo (escolas próximas em reunião com a equipe das coordenadorias), os GAAEs (grupos de acompanhamento da ação educativa), os encontros no NAE (Núcleos de ação educativa) e na DOT (diretoria de orientação técnica). A gestão de Marta retomou contratos com a USP e a PUC para participação dos GAAEs (no diagnóstico das condições reais da rede) e definiu ênfases em: inclusão, alfabetização e avaliação.

Os programas de formação continuada em serviço de Marta, segundo a autora, também sofreram descontinuidade e fragmentação por conta da mudança de quatro secretários da educação, mas mantiveram a concepção da formação do professor prático-reflexivo, e da escola como lugar de formação.

A autora analisa cada projeto de formação ocorrido nessa gestão e de seu discurso tiramos a forma como a mesma é apresentada através de muitos termos que a positivam, como: retomou conversas com a comunidade escolar, retomou a escola pública participativa que trabalha para apresentar o mundo ao aluno e para que o mesmo possa se desenvolver e escolher seu lugar nele, democratização do conhecimento, qualidade social da educação, democratização do acesso, permanência da formação, continuidade, aprofundamento, vinculação da formação teórica com o cotidiano, construiu junto (não decretou), superou fragmentação, trabalhou em rede (e não com hierarquia vertical), teve muita iniciativa, foi criativa, reuniu, reorientou, deu liberdade, sistematizou conhecimentos produzidos no coletivo pelos educadores, deu responsabilidades a, dividiu responsabilidades e decisões, organizou as 
relações entre órgãos, estruturou e relacionou (o que estava desestruturado e dividido); entre muitos outros.

Governos mais democráticos, segundo as autoras consultadas, tendem a colocar o formador e o professor no lugar do intelectual, pesquisador e prático (capaz de relacionar teoria e prática), um ser reflexivo, participativo, mediador crítico e capaz de gerir sua própria formação através da escuta e levantamento coletivo das necessidades. Os problemas educacionais são vistos em forma de rede e a formação não é compreendida como redentora, mas como possibilidade de construção de novos lugares profissionais nos quais os educadores consigam ser mais criativos e mais livres para experimentar e para responder aos desafios do presente, valorizando os percursos coletivos (as decisões são tomadas no coletivo). Nesse sentido as singularidades de percurso e as experiências são valorizadas, ao mesmo tempo em que os saberes da academia. Segundo as autoras, os educadores são beneficiados por gestores mais democráticos, o que gera muitas expectativas de participação e melhorias na vida profissional.

Os ciclos político-educacionais são apresentados numa relação de oposição entre partidos políticos: Covas em oposição ao governo anterior (Curiati e Lima), Jânio em oposição a Covas. Erundina em oposição a Jânio. Maluf e Pitta em oposição a Erundina. Marta em oposição a Pitta.

Souza (2005) em sua conclusão traz mais um elemento que queremos comentar e que diz respeito a um dos cargos públicos, a supervisão. Esse cargo também é apresentado em oposição criada a partir de posições políticas. A autora diz que o seu histórico o inscreve hierarquicamente acima dos demais, assim, o cargo permanece independente da mudança das gestões, criando um cenário mais ou menos como esse: as políticas passam e os supervisores ficam. A cada troca de gestão, os supervisores são "convidados" a participar da implantação das diferentes propostas, pois representam o Estado. Nos governos definidos como autoritários, a função supervisora teve um caráter mais técnico e burocrático: repasse de planos, controle de metas e da sua execução. Nas gestões mais democráticas, foi concebida como ação educativa (social e política), reservou-se um lugar para o supervisor de articulador entre as escolas e os órgãos oficiais, tendo como objetivo traduzir necessidades e desejos e ajudar a definir políticas. 
Como pudemos ver nas vozes selecionadas, em torno das políticas públicas educacionais habitam muitas expectativas, sendo a de participação a mais recorrente. As atribuições no sentido do que deveriam ser ou fazer estão localizadas ao lado das experiências democráticas, mesmo quando criticadas. No discurso das autoras selecionadas os saberes valorizados são os identificados com a concepção democrática e os saberes rejeitados são os identificados ou produzidos em governos autoritários. Os personagens são dispostos em grupos e em oposição (pois são organizados sempre em comparação; personagens de um ciclo político a outro). Muitas são as tensões decorrentes de grupos que se opõem na tentativa de influenciar, governar e conduzir os trabalhos. Tensões internas no mesmo grupo ou partido político são também identificadas, no sentido de discordâncias de concepções de trabalho. A demanda recorrente feita à formação dos educadores, com as lentes da política, foi a de formar pessoas mais participativas e críticas. 


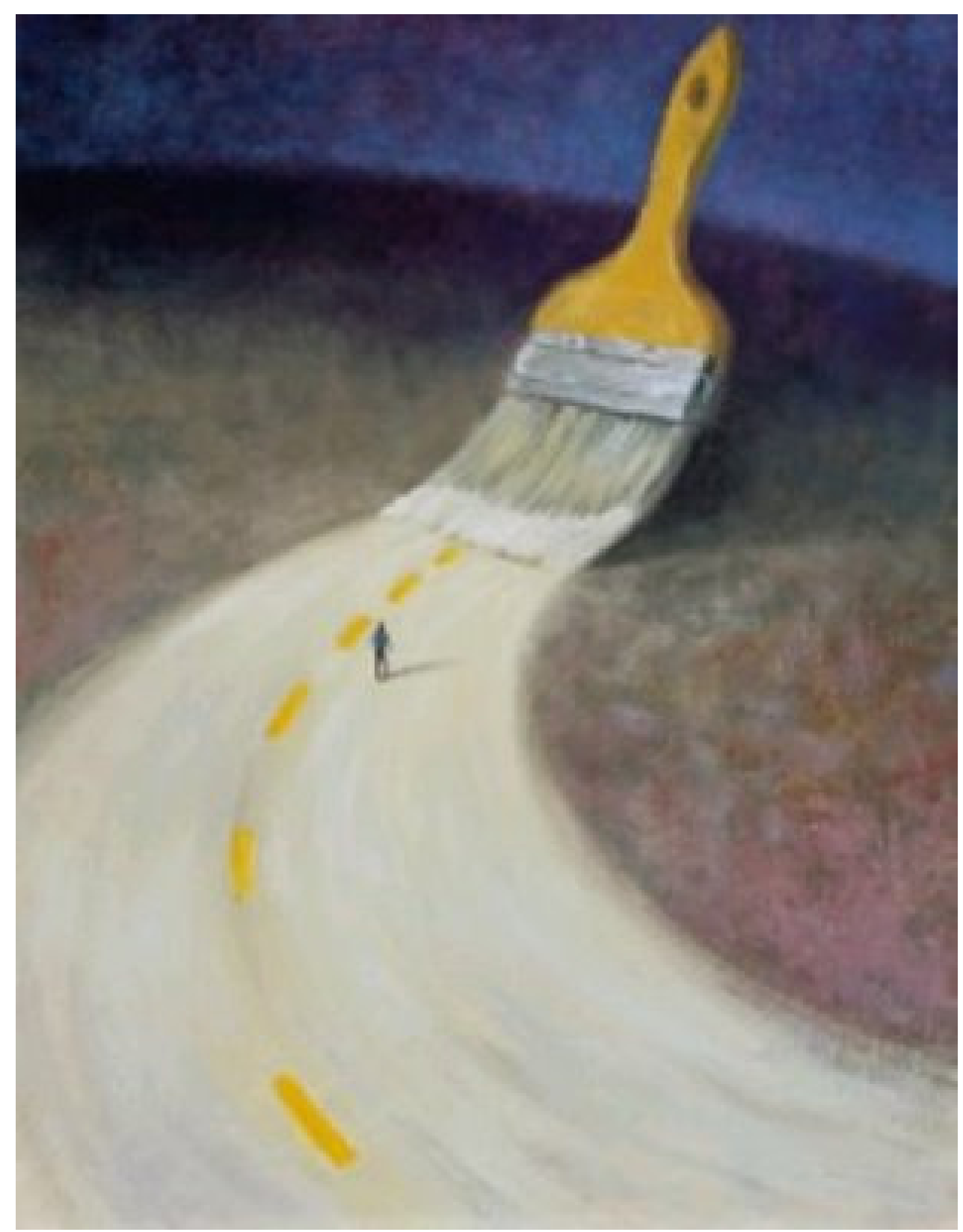

Fonte texto visual: autor desconhecido, caminhante, 319X396 cm, 2011.

Disponível em: http://www.google.com.br/search/caminhante. Acesso em: 02-01-2010. 


\section{4- MÉTODO}

\section{1 - A construção do problema da pesquisa}

Para compreender o contexto de produção da atual pesquisa, no sentido do cenário relacional e jogo de expectativas presentes, apresentamos a seguir o histórico de relacionamento através do trabalho em comum da pesquisadora com as pessoas que compõem a pesquisa.

O percurso que fizemos começou no ano de 2003, na gestão da prefeita Marta Suplicy (2000 a 2004). Um grupo de 20 pessoas da rede municipal de São Paulo foi constituído para fazer a formação continuada de uma parte das escolas municipais de São Paulo, entre elas creches, escolas de educação infantil, fundamental 1 e 2 e Educação de Jovens e Adultos. As áreas de informática e inclusão atendiam a todos os segmentos. Os profissionais foram convidados pela gestão daquele momento a saírem de suas funções concursadas (professores, coordenadores pedagógicos, diretores e supervisores) para exercerem novas funções, agora na Coordenadoria ${ }^{23}$.

Duas pessoas da equipe técnica da Coordenadoria de educação procuraram a instituição privada de formação de educadores Espaço Pedagógico pedindo ajuda para pensar tal prática de formação continuada de educadores, tendo como foco a constituição dos grupos de trabalho, a compreensão dos conflitos relacionais no trabalho e a função do coordenador de grupos. A atual pesquisadora assumiu a coordenação e o acompanhamento desse grupo.

São Paulo, na gestão da prefeita, foi dividida em 31 subprefeituras e a política educacional, estruturada em sete coordenadorias a elas ligadas, sendo que cada coordenadoria foi organizada para atender uma região, um grupo de bairros de São Paulo.

23 A Coordenadoria concentrava grupos de trabalho designados para pensar a formação de educadores, administrar as escolas de uma região da cidade de São Paulo, bem como para criar e acompanhar programas e planejamentos. A coordenadoria pertence à secretaria municipal de educação. 
Segundo Pereira (2004, p.12-13): Na perspectiva da reconstrução de uma nova ordem, calcada nos princípios da descentralização, participação popular, humanização das relações sociais, implementou-se a divisão da cidade em 31 subprefeituras. Consolidada através de uma lei municipal em agosto de 2002 tem início uma imensa reforma administrativa que se torna exemplo para vários países do mundo. [...] A portaria Intersecretarial n.6, publicada em 2002, estabelece a estrutura organizacional das subprefeituras com as respectivas competências e atribuições, desde o gabinete do subprefeito até as sete coordenadorias onde a coordenadoria de educação está inserida. No novo organograma criado para as coordenadorias de educação enquanto integrantes da subprefeitura, e também na nossa visão, é central o seu papel formador. Constituída por três diretorias, a diretoria técnica de planejamento, a diretoria de programas especiais e a diretoria técnico-pedagógica, as ações de formação são decorrentes dessas duas últimas diretorias. A supervisão escolar, como instância de assessoramento ao coordenador de educação, possui atribuições de caráter administrativos e pedagógicos, articulando ações das três diretorias.

Os integrantes do grupo eram responsáveis pelas ações de formação das unidades educacionais pertencentes a uma das Coordenadorias na cidade de São Paulo e faziam parte da equipe pedagógica. Estavam ligados à política da SME (secretaria municipal de educação) e suas diretrizes gerais como nos diz Pereira (2004, p.12):

Tendo em vista a reorganização e reforma administrativa da cidade é necessário retomar os encaminhamentos estabelecidos no início e reafirmar as diretrizes da política educacional da Secretaria Municipal de Educação. É elaborado coletivamente por integrantes das coordenadorias, da diretoria de orientação técnica e da secretaria, o caderno EducAção 4, que estabelece prioridades e metas para a implementação da diretriz Qualidade Social da Educação.

Ao longo de um ano e meio, foram feitos encontros quinzenais com esse grupo para pensar o lugar de cada um, a formação continuada em construção, ao mesmo tempo em que tecíamos o projeto coletivo de formação de educadores daquela coordenadoria. Ao final de 2004 a experiência foi sistematizada em um material impresso pela Secretaria Municipal de Educação de São Paulo (SME), chamado de As redes da experiência: relatos reflexivos de um grupo de educadores da coordenadoria de Educação. Cada integrante pôde organizar seus estudos, suas aprendizagens e seu lugar de formador dentro do contexto institucional, trazendo um pouco da sua função, seu referencial teórico, sua experiência e suas escolhas. 
Nos relatos reflexivos, encontramos delineada uma proposta de política educacional para os formadores de educadores. Todos os membros do grupo estavam muito mobilizados com os textos produzidos no final da gestão da prefeita (dezembro de 2004), que para a surpresa geral foi derrotada nas eleições seguintes pelo novo prefeito José Serra, de outro partido político, que constituiu outra política, outra estrutura de trabalho e outro grupo de educadores foi chamado para as funções formativas da mesma região de São Paulo (janeiro de 2005).

As 20 pessoas que compunham o primeiro grupo e que chamarei de Grupo 1 ao longo das análises, se dividiram e a proposta vivida e sistematizada foi engavetada. Algumas pessoas permaneceram na coordenadoria por simpatia ao novo projeto, para tentar alguma continuidade e/ou exerceram novas funções em novos cargos. As demais voltaram para suas funções concursadas e escolas anteriores.

Os membros do Grupo 1, durante a gestão de Marta Suplicy, embora pertencentes a partidos políticos variados, uniram-se em torno de objetivos políticos e educacionais comuns, e opuseram-se à política dos últimos oito anos, dos prefeitos Paulo Maluf (1993-1996) e Celso Pitta (1997- 2000), cujas marcas foram compreendidas por Pereira (2004, p.12) como:

O município de São Paulo estabeleceu em seu plano de governo para a cidade na gestão da Prefeita Marta Suplicy (2001-2004), uma inversão de prioridades para essa cidade desigual, caracterizada por um centro que possibilita o acesso ao consumo sofisticado e uma periferia desprovida de condições mínimas de existência: investir nas camadas mais necessitadas da população. Esta ação teve como foco quebrar o ciclo da pobreza e a lógica construída pelas políticas neoliberais, nas quais é natural dois terços da população estarem precariamente incluídos ou totalmente excluídos das condições dignas de vida, isto é, possuírem trabalho, moradia, boa alimentação, educação e saúde. [...] A dimensão proposta faz frente a um passado recente, enquanto na década de 1990 procurou-se modernizar a gestão pública do país, São Paulo esteve mergulhada no projeto conservador que transformou a máquina administrativa em parte da engrenagem no processo exclusivo de produção de obras. 
Tomaram como modelo inspirador os grupos de formação de educadores constituídos na gestão da prefeita Luíza Erundina (1989-1992) ${ }^{24}$. Algumas pessoas do Grupo 1 fizeram parte desse modelo ainda hoje muito valorizado por vários educadores da rede municipal e que pudemos conhecer no capítulo 3.

A experiência do exercício do poder no lugar da Coordenadoria (fazer parte de um grupo "coeso", que fez formação de educadores de uma região de São Paulo e influenciou as práticas educacionais segundo uma concepção entendida e definida como "transformadora" da escola, como veremos aparecer nos discursos produzidos) experimentada pelos membros do Grupo 1, deixou marcas que poderemos observar adiante através da análise do discurso das educadoras.

Em 2005, algumas pessoas do primeiro grupo da coordenadoria, juntamente com outra educadora ainda desconhecida, procuraram a pesquisadora (que já estava fora da instituição privada de formação de educadores), sendo que elas não estavam mais na Coordenadoria. Trouxeram uma nova demanda: continuar os estudos de grupo e as análises das práticas educativas e conversar sobre as mudanças de lugar profissional. Chamou a atenção na ocasião, como já foi dito anteriormente, o desânimo e a imobilização das educadoras diante dos desafios que diziam estar vivendo em seus locais de trabalho. Quais seriam tais desafios? Esta pergunta mobilizou os encontros. Trabalhamos o ano todo, uma vez ao mês, e muitas foram as queixas a respeito do ambiente de trabalho. Ao final, cada uma produziu um planejamento para 2006, olhando para os desafios vividos no ano, que foram muitos. O planejamento nasceu das análises dos seus lugares institucionais, suas funções, bem como de suas escolhas e desejos de mudança. Este será nomeado como o Grupo 2.

No ano de 2006 uma parte das pessoas do Grupo 2 voltou a formalizar um pedido de acompanhamento. Algumas pessoas do segundo grupo permaneceram, outras saíram e uma pessoa nova entrou. Realizamos nove encontros de julho a dezembro e a demanda foi voltar aos estudos, sendo que agora cada integrante apresentaria um texto para ser debatido nos encontros. O formato dos encontros mudou muito, a pessoa que apresentava o texto a ser discutido é quem coordenava o grupo naquele encontro. Foi estabelecida uma espécie de

No site http//portalsme.prefeitura.sp.gov.br encontramos o acervo documental da época em que Luíza Erundina assumiu a prefeitura de São Paulo e introduziu os grupos de reflexão como uma metodologia de formação continuada de servidores, usada em vários setores da saúde e educação. Ver também: SME SP 1990. Cadernos de Formação n.1. Grupos de formação: uma revisão da educação do educador. DOT. 
rodízio no intuito de valorizar o caminhar sem planejamento prévio (pauta). Propusemos, portanto, uma mudança no lugar da coordenadora do grupo, que não centralizaria mais a coordenação, seria uma participante que ajudaria a pensar e estudar, e não receberia pagamento, como antes, por um acompanhamento do grupo. Esse será nomeado como o Grupo 3.

Em março de 2007, novamente procurada por uma parte do grupo, levantamos hipóteses de trabalho. Em Julho, a pesquisadora procurou o grupo e propôs os quatro encontros para falarem da vida profissional como formadoras de educadores na rede municipal de São Paulo. A proposta era analisar os discursos produzidos nos encontros, com o método de Análise Institucional do Discurso. A pergunta norteadora da pesquisa foi: o que se passa com as educadoras formadoras ao longo do seu percurso profissional que é atravessado por mudanças políticas a cada troca de gestão? O que e como falam a respeito desse lugar profissional? Como desenham os lugares no discurso ${ }^{25}$ ? Como se veem e se reconhecem nesse lugar?

\section{2 - Caracterização desta pesquisa}

A partir do histórico exposto acima, constituímos, então, uma quarta formação de grupo, agora com oito integrantes do antigo terceiro grupo. Desta vez a demanda foi da pesquisadora, o que configurou um espaço novo de trabalho para falar de como se viam em seus espaços profissionais.

As integrantes deste quarto grupo são educadoras que têm, na sua maioria, um trabalho e estudo sistematizados. Os cargos ocupados por elas no ano de 2007 (ano da realização das sessões para a presente pesquisa) variaram entre supervisão, coordenação, professora itinerante que circula nas escolas acompanhando, assessorando e apoiando a inclusão (PAAI), sendo que todas tinham, na época, uma ação formadora com seus grupos de professores, funcionários e/ou equipe técnica. Algumas ocupavam os cargos de origem, ou

\footnotetext{
25 O que mostram na ação de dizer, no modo de enunciar - como falam da cena enunciativa, da distribuição e organização de lugares, relações e expectativas.
} 
seja, os conquistados por concurso, enquanto outras estavam exercendo suas funções em cargos-convite.

O material para a análise se constituiu de quatro sessões em grupo com oito educadoras-formadoras da rede municipal de educação, feitas com um intervalo quinzenal e com a duração de aproximadamente 1,5 a 2 horas. As sessões de grupo foram taquigrafadas em ato por uma profissional contratada pela pesquisadora, além de gravadas. Todo o material foi transcrito e conferido. A segunda sessão foi anotada com a colaboração das integrantes do grupo de pesquisa e por isso teve uma duração de aproximadamente 1 hora (a taquígrafa teve problemas e não compareceu). Consideramos que a anotação foi fiel aos discursos, não os prejudicando, mas influenciou os mesmos no sentido das pausas que as educadorasformadoras faziam para possibilitar a anotação, seguiram assim um ritmo mais lento de fala. A interrupção desta sessão foi feita próxima ao tempo acordado, mais curto, o que também fez parte das condições de possibilidade dos discursos daquele dia.

No intervalo entre a segunda e a terceira sessão do grupo a presente pesquisadora contou com a colaboração do grupo de orientação da professora doutora Marlene Guirado, na análise dos discursos produzidos, o que configurou certos desafios na condução das sessões que serão explicitados e farão parte das análises das sessões grupais como condições de produção do discurso.

Depois de cada sessão, a pesquisadora esboçava uma análise do material escrito para reconduzir os trabalhos na sessão seguinte.

Vamos agora aprofundar os conceitos referenciais já anunciados na introdução e que funcionaram como norteadores da experiência.

\section{3 - O referencial conceitual do método}

O método, neste trabalho, é o da Análise Institucional do Discurso tal como foi proposto por Guirado (2007; 2009). Mais especificamente, é uma experiência de trabalho com ele, em grupo, na dimensão institucional dos grupos. 
No livro organizado em parceria com Lerner, Guirado (2007, p.14) traz no prefácio uma sistematização do método batizado por ela de Análise Institucional do Discurso. Interessante acompanhar como o conceito de método ganha novos matizes e é definido como "uma estratégia de pensamento que se organiza em torno de um conceito, ou de conceitos". Na proposta da AID encontramos uma maneira de pensar as práticas institucionais e de fazer análise de discurso em psicologia. Para apresentar o trabalho nesta perspectiva, temos que caracterizar os seguintes conceitos norteadores: subjetividade, instituição, discurso e análise.

Guirado em sua tese de livre docência (2009, p.223) conta como costuma ser arguida em bancas nas quais figura como examinadora, sobre a possível "restrição que o recorte discursivo impõe ao material psicológico", ao que ela responde que nessa pergunta a pressuposição é de que os afetos e a subjetividade (material por excelência reconhecido como "psicológico") ocorreriam ao largo do discurso: "o pressuposto dessas interpelações é que o discurso estaria cindido dos afetos" (GUIRADO, 2009, p.223). A autora continua: "em grande parte dos estudos, crê-se poder fazer das falas, o caminho transparente, não fossem os empecilhos inconscientes" (idem, ibidem, p.223). Na AID as lentes para a leitura do material discursivo partem de um campo conceitual que entende o discurso como fonte de pesquisa da subjetividade: nele são configurados afetos, posições são assumidas e delegadas; relações são imaginadas (e tem o efeito de produzir reconhecimentos e desconhecimentos); e há recorrências de cenas. São, todos, pontos privilegiados para pensar a constituição da subjetividade.

Apresentaremos os conceitos-referência com objetivos didáticos, declarando de antemão que se entrecruzam e se complementam na sua composição; nesse sentido, um termo pode aparecer na definição do outro, que será objeto de discussão logo em seguida. Portanto, as inter-relações ficarão mais claras, ao final.

\section{Subjetividade}

A subjetividade, a partir deste método, é compreendida como produzida nas práticas sociais, tecida e mostrada na fala de cada um. O sujeito é ao mesmo tempo suporte e efeito do discurso que faz e recebe. É constituído nas e constitutivo das relações institucionais concretas que faz, desde o nascimento, com outras pessoas, nos diferentes contextos de vida. 
Guirado (2006, p.86) propõe que aquele que fala de si, o faz a partir das condições institucionais que permitem que ele o faça de uma determinada maneira. Ela propõe então o conceito de sujeito como dobradiça:

Como uma dobradiça, dessas de portas, facilitamos o movimento das singularidades discursivas e, ao mesmo tempo, acusamos aquilo que parece ser o regime discursivo da marginalidade ${ }^{26}$ numa formação social que desta maneira a inclui entre suas formas de acontecer e se instituir. A questão, inclusive, não está em analisar isoladamente as entrevistas e no conjunto delas reconhecer as regularidades. Até porque estas se podem reconhecer no interior de uma mesma fala. A questão está na perspectiva que se tem de análise, os recortes que ela permite e as "amarrações" ou as reconstruções a que se chega, que acabam falando ao mesmo tempo dos autores das cenas enunciativas e das condições de enunciação. Aí, a metáfora da dobradiça de sujeito. Pode não ser elegante, mas funciona.

A concepção do sujeito como dobradiça mostra um lugar de tensão entre a rede discursiva (como se distribuem os lugares no campo das relações analisadas) que forma as condições de enunciação, e o autor da cena enunciativa, que aponta para a singularidade. As identificações pelo direito (legitimação) ou pelo avesso (transgressão) podem mostrar a repetição ou a resistência frente às expectativas presentes nas redes institucionais.

Neste jeito de olhar a produção da subjetividade, esta não vem antes, não existe como uma essência a ser descoberta ou revelada, ela é constituída e produzida como efeito das relações que fazemos concretamente.

A analítica da subjetividade se dispõe a pensar o que e o como cada pessoa fala de seu movimento nas relações concretas que faz, constituindo assim, um modo diferente de conceber o campo psíquico, como nos explica Guirado (2009, p.152): "E assim o configuramos como uma organização singular, histórica, de um espetacular entrecruzamento de discursos, enunciações, matriciada em relações institucionais. Como dissemos antes: sujeito psíquico, porque sujeito institucional".

Esta estratégia de pensamento configura, portanto, um tipo de subjetividade: o modo como a pessoa fala de si, o como ela se reconhece (ou o que desconhece) no exercício das relações que faz. A subjetividade é entendida então como efeito dos exercícios relacionais -

\footnotetext{
26 Neste extrato, Guirado analisava um trecho do discurso de um dos internos da Febem- SP, por isso a referência ao regime discursivo da marginalidade.
} 
institucionais: é nas relações sociais que o sujeito vai experimentar sentimentos, fantasias, viver conflitos, receber e delegar lugares, que são imaginados, repetidos e legitimados. É na combinação das histórias, dos lugares institucionais, dos poderes e saberes exercitados e das posições ocupadas, que as marcas subjetivas se constituem.

\section{Instituição}

As instituições são entendidas como práticas sociais que se repetem, e, ao se repetirem, legitimam-se como "naturais", produzindo efeitos de reconhecimento de que o conjunto de ações e relações daquele campo "é" assim, e, ao mesmo tempo, efeitos de desconhecimento (de sua relatividade). Guirado (2009, p.36) partiu da definição de instituição construída por Guilhon de Albuquerque: "conjunto de relações e práticas sociais que se repetem, e, nessa repetição, legitimam-se". Não são confundidas, portanto, com o espaço físico ou organizacional de certos grupos, ou como uma área de atuação.

A instituição é produzida pela ação dos seus atores: agentes e clientela, respectivamente os que produzem o serviço e o oferecem e os que o demandam e usufruem. Na separação de campos de ação em relação a outras instituições, está o objeto institucional, como nos explica Guirado (2009, p.37): "toda instituição constitui um objeto (imaterial, impalpável): é aquilo (ou a relação básica) em nome de que ela se faz, e cujo monopólio é reivindicado numa delimitação de âmbito de ação com outras instituições".

Este método de trabalho em Psicologia, segundo Guirado (2009, p.151) define seu objeto institucional como "as relações, do modo como são imaginadas, reconhecidas e desconhecidas pelos que as fazem, no e pelo discurso".

\section{Discurso}

O discurso na AID é entendido, com a contribuição de Foucault (2000), como acontecimento, ato, enunciação. O "quem" diz, está atrelado ao "onde”, assim, o que se diz, 
não se diz de qualquer lugar: é marcado por um determinado momento histórico, por uma região geográfica, por certa relação entre as pessoas. Saberes e campos de poder organizam o pensamento, o discurso e a relação consigo mesmo e com o outro. O discurso poderia, então, ser compreendido como uma ação concreta, regulada, que estabelece a cada momento, o que, por quem, contra quem, em que contexto e de que forma pôde ser expresso. A "produção do discurso é ao mesmo tempo controlada, selecionada, organizada e redistribuída por certo número de procedimentos que têm por função conjurar seus poderes e perigos, dominar seu acontecimento aleatório, esquivar sua pesada e temível materialidade" (FOUCAULT, 2000, p.9).

A AID procura analisar o que ocorre no discurso, os acontecimentos do dito em sua positividade, em sua produção, as regularidades, a relação que constitui (no sentido dos lugares que organiza - que fixa ou resiste - para os atores institucionais) e as transformações e cortes que possibilitam.

É no discurso, portanto, que estudaremos a relação (a formação da subjetividade a partir da relação consigo e com o outro), o poder que se exerce sobre si e sobre os outros (uma relação de forças, um poder de se afetar e afetar o outro e as possibilidades de resistências - a luta pelo direito à diferença, pela não submissão e dominação, pela independência), a instituição, bem como o próprio contexto de sua produção.

O contexto não é confundido com o momento histórico, algo que estaria ao redor, ou fora do texto, mas definido como realidade negociada entre os parceiros de fala, portanto, em constante construção. Guirado (2000, p.30) diz: "Mas o contexto está também na cabeça das pessoas [...] Um contexto não é uma realidade objetiva, é algo que os parceiros de fala têm na cabeça". E ainda: "cada um define, por intermédio de sua fala, o contexto no qual está falando. Os falantes cooperam ou brigam para definir o contexto no qual estão falando. $\mathrm{O}$ discurso não está somente no contexto, mas está sempre construindo esse contexto" (GUIRADO, 2009, p.30). Ao analisar o modo de produção do discurso, chegamos, portanto, na constituição de subjetividades.

Segundo Guirado (2007, p.15) "palavras e expectativas são ato. Ato instituinte de um conjunto de verdades mostradas como discurso. Onde encontrar situação tão exemplar de instituição?". E, “Se com Foucault, entendo o discurso como dispositivo institucional, como 
acontecimento, como ato, a posição do falante é concretamente a ocasião da produção de sentidos, expectativas de reação no parceiro-interlocutor”. (GUIRADO, 2007, p.17).

É no discurso que ocupamos lugares para falar com os outros e tais arranjos fazem efeitos tanto em quem diz como em quem escuta. Falar implica estabelecer relações: é um exercício que organiza posições. O ouvinte é entendido como fiador do sentido ou coenunciador do discurso. Segundo Maingueneau (1995), o falante constrói uma imagem do ouvinte e adequa seu discurso para falar-lhe, fazendo, portanto, parte dele. O ouvinte, por sua vez, garante a veracidade do discurso, quando confirma os sentidos produzidos e com isso, autoriza os lugares de cada termo em relação. De acordo com Guirado (2000, p.31), o sujeito que fala: "está sempre dentro do seu enunciado tomando uma certa atitude em relação com o que está dizendo: não tem na linguagem, uma separação entre a atitude do falante e o conteúdo. Não se pode separar o que se diz da posição do sujeito que fala com respeito a seu enunciado e a seu co-enunciador".

\section{Análise}

Seguindo o curso das ligações entre os lugares de certa forma distribuídos no discurso podemos observar o conjunto de relações institucionais concretas que constroem o sujeito. A análise é o modo como vamos construir o caminho em busca das relações tal como são construídas no discurso de quem as faz concretamente no cotidiano das práticas sociais. Ela é balizada por conceitos que não dizem antes de começar onde vamos chegar, mas funcionam como lentes de leitura, dirigindo nosso olhar para o que se produz enquanto fala.

A análise feita com esse modo de pensar vai entrelaçar o método com o objeto da pesquisa, discurso e realidade psíquica, os modos de proceder com os resultados. Vai ajudar a pensar as instituições que fazemos com nosso discurso-ato, o que não se configura como interpretação de sentidos, mas como construção. Diz Guirado (2007, p.16): "Será exatamente a rede de conceitos que organiza o pensamento daquele que diz que mostrará o sentido do dito" [...] "por essa tradição (aquela em que produzimos), o intercontexto (a relação entre contextos), o interdiscurso, é o engenho instituinte de sentidos para o que se faz ao dizer, ou mostra-se enquanto se diz". 
A análise vai configurar um saber relativo ao modo de sua produção concreta, afirmará algo a partir de recortes, portanto, sempre parcial.

\section{AID e o entrecruzamento dos conceitos: subjetividade, instituição, discurso e} análise

Na AID, a subjetividade é configurada por uma análise que faz uma desconstruçãoreconstrução do discurso, entendido como prática, como ação. No discurso, cenas são montadas a partir das posições dos personagens e dos lugares dispostos institucionalmente, configurando as expectativas cruzadas e jogos de força entre os interlocutores em relação. Nesse discurso-ação ocorrem reconhecimentos de si e do outro, o que produz saberes e verdades.

As orientações deixadas por Foucault em A Ordem do Discurso (2000, p.51) são preciosas para o processo de análise: "questionar nossa vontade de verdade; restituir ao discurso seu caráter de acontecimento; suspender, enfim, a soberania do significante". O que não significa que a pesquisadora tenha conseguido seguí-las ou alcançá-las o tempo todo ao longo do trabalho.

\section{4 - Algumas palavras sobre mais um conceito norteador: as relações de poder}

Desde o começo deste trabalho esteve presente uma inquietação: o campo da formação continuada de educadores compreendido como uma instituição (relações sociais que se repetem e se legitimam) apresenta um jogo de forças bastante particular que, sendo feita na instituição pública municipal, compõe uma cena própria. O objeto em nome do que essa instituição se faz é o desenvolvimento ou a transformação do educador. A definição do que o educador era antes e do que deve ser com a ajuda da formação é construída e modificada em cada período sócio- histórico, como pudemos ver nos capítulos iniciais. O modo e o caminho que será tomado para se alcançar o "lugar profissional a ser desenvolvido" também sofre as variações históricas. 
As práticas de formação em busca de seus objetivos organizam uma relação social que posiciona dois personagens: de um lado estão os "formadores" que vão oferecer um serviço a partir de saberes que são considerados importantes (são os agentes) e de outro, os educadores que vão receber e demandar o serviço (clientela). Esta relação entre os formadores e educadores recebe um terceiro termo que arbitra e influencia ambos: as políticas públicas que são exercidas a partir de representantes que também variam conforme os períodos políticos, tornando-se formadores ou os que definem os caminhos da formação a serem trilhados. Podemos compreender a partir do cenário proposto, como um campo de relações tensas se delineia em torno do objeto e dos personagens. Tais relações estão permeadas de exercícios (atos) e estratégias, que movimentam correlações de forças e que podem ser caracterizadas como relações de poder.

Com a ajuda de Foucault (2007, p.103), podemos compreender o poder como: "multiplicidade de correlações de força imanentes ao domínio onde se exercem e constitutivas de sua organização; o jogo que, através de lutas e afrontamentos incessantes as transforma, reforça, inverte; os apoios que tais correlações de força encontram umas nas outras”. O poder, diz Foucault (2007, p.103): "se produz a cada instante, em todos os pontos, ou melhor, em toda relação entre um ponto e outro [...] é o nome dado a uma situação estratégica complexa numa sociedade determinada"; e ainda: "o poder se exerce a partir de inúmeros pontos e em meio a relações desiguais e móveis" (FOUCAULT, 2007, p.104). O exercício do poder é um modo de ação de uns sobre outros e, portanto, deve ser olhado como relações de poder.

Guirado (2009), apoiada em Foucault, nos ajuda a pensar o poder como verbo (ação sobre ação) e não como substantivo (poder como alguma coisa que alguém possui e utiliza) ou como adjetivo (ser bom ou mau). Essa ação, segundo a autora, aponta para o caráter produtivo das relações de poder e complementa que essa ação se dá por afrontamentos, que por sua vez acontecem no discurso: "o discurso como o lugar mesmo em que essas lutas se fazem; como o lugar das relações de poder, como o que se cerceia, limita e controla" (GUIRADO, 2009, p.81). As relações de poder são "os efeitos imediatos de partilhas, desigualdades e desequilíbrios que se produzem nas mesmas [...] e possuem, lá onde atuam, um papel diretamente produtor" (FOUCAULT, 2007, p.104). São "relações em que cada um procura dirigir a conduta do outro" (FOUCAULT, 2006, p.276).

As correlações de poder são estritamente relacionais: "elas não podem existir senão em função de uma multiplicidade de pontos de resistência que representam, nas relações de poder, o papel de adversário, de alvo, de apoio, de saliência que permite a preensão. Esses 
pontos de resistência estão presentes em toda a rede de poder" (FOUCAULT, 2007, p.106). Foucault (2007, p.106) diz que há "resistências, no plural que são casos únicos: possíveis, necessárias, improváveis, espontâneas, selvagens, solitárias, planejadas, arrastadas, violentas, irreconciliáveis, prontas ao compromisso, interessadas ou fadadas ao sacrifício; por definição, não podem existir a não ser no campo estratégico das relações de poder". A resistência aparece onde há relações de poder: "que lá onde há poder há resistência e, no entanto (ou melhor, por isso mesmo) esta nunca se encontra em posição de exterioridade em relação ao poder" (FOUCAULT, 2007, p.105.).

O movimento de poder e as resistências, segundo o autor, estão sempre presentes em qualquer relação que não seja de violência, pois nestes casos, subtrai-se a possibilidade da existência da resistência e com ela, a possibilidade de escapar, se mover, atacar, inverter a situação e etc. Portanto, "para que se exerça uma relação de poder, é preciso que haja sempre, dos dois lados, pelo menos uma certa forma de liberdade" (FOUCAULT, 2006, p.277). Pensar o movimento de poder e de resistência, com Foucault, segundo Guirado (2009, p.85) leva-nos a "desenhar um mapa das tensões entre posições e oposições" que ocorrem na relação e verificar o que se produz de saberes e verdades através desse procedimento.

Interessou a Foucault (2006) compreender como o sujeito entra em um dado jogo de verdade que se produz nas relações de poder e de saber. Este modo de pensar apresenta um sujeito ativo diante de sua construção, no sentido de que o discurso exerce sobre ele uma força de constituição e o leva a governar-se através do que o autor chama de práticas de si: "esquemas que ele encontra em sua cultura e que lhe são propostos, sugeridos, impostos por sua cultura, sua sociedade, seu grupo social" (FOUCAULT, 2006, p.276).

Pensar na formação municipal de educadores, o movimento das relações de poder e as resistências exercidas implica em destrinchar a ação sobre ação em exercício. O verbo formar, extraído da palavra formação, poderia ser desdobrado em outras ações correspondentes: dar forma, fabricar, moldar, conceber, constituir, fundar, assemelhar, adquirir, preparar, compor, aperfeiçoar, capacitar, influenciar, dirigir, governar, dominar, determinar, convencer, e enfim, educar, entre outros verbos possíveis, compondo todo o tipo de resposta do outro lado da relação (o que recebe a ação e responde a ela com novas ações).

A educação (formação) ao mesmo tempo em que abre o acesso para todos os tipos de discurso, também cerceia, submete e impede. A educação é um lugar onde lutas se travam, como diz Foucault (2000, p.44): “todo sistema de educação é uma maneira política de manter ou de modificar a apropriação dos discursos, com os saberes e os poderes que eles trazem 
consigo". Se todas as relações são relações de poder e se dirigem para influenciar - governar a ação do outro, então, quando pensamos em educar e formar através de políticas públicas definidas pelo Município, ou pelo Estado, entendemos como a instituição "formação de educadores" se institui e se organiza numa prática de jogos de poder: dirigir, governar o outro.

Foucault complementa (1995, p.247):

As formas e os lugares de governo dos homens uns pelos outros são múltiplos numa sociedade: superpõem-se, entrecruzam-se, limitam-se e anulam-se, em certos casos, e reforçam-se em outros. É certo que o Estado nas sociedades contemporâneas não é simplesmente uma das formas ou um dos lugares - ainda que seja o mais importante - de exercício de poder, mas que, de um certo modo, todos os outros tipos de relação de poder a ele se referem. Porém, não porque cada um dele derive. Mas, antes, porque se produziu uma estatização contínua das relações de poder (apesar de não ter tomado a mesma forma na ordem pedagógica, judiciária, econômica, familiar). Ao nos referimos ao sentido restrito da palavra governo, poderíamos dizer que as relações de poder foram progressivamente governamentalizadas, ou seja, elaboradas, racionalizadas, centralizadas na forma ou sob caução das instituições do Estado.

Um marco que caracteriza e compõe a forma historicamente constituída a respeito da prática da formação continuada de educadores no município de São Paulo é o fato de ela estar diretamente vinculada às relações políticas, que por sua vez, desenham, organizam, governam e controlam as práticas. É a presença direta do Estado na forma de trabalhar desses profissionais da educação (através de escolhas teóricas, da definição de projetos, dos materiais didáticos, da organização da escola, da determinação da remuneração, da concepção de formação e etc.), que, como mostramos nos capítulos iniciais, jogam com ingredientes e personagens que mudam em cada momento histórico e produzem (maior ou menor) dominação, abrem mais campos de possibilidades ou não. Nos discursos, o Estado (através de seus representantes) aparece como um termo da relação sempre presente, configurando o jogo de expectativas. Nas políticas públicas educacionais há um "lugar" idealizado (que muda conforme as forças em jogo e vão sendo modificadas em cada tempo histórico) para onde se quer levar o educador e que pode ser entendido como um lugar que objetiva o sujeito porque o caracteriza, qualifica, nomeia, prescreve. Este movimento produz efeitos nos educadores em formação e também nos formadores de educadores. 
Com Guirado e o conceito dobradiça de sujeito (2009), podemos nos interrogar sobre quais são as subjetividades-efeito das relações (de poder) construídas institucionalmente e a partir das sessões do grupo de pesquisa, enquanto os educadores-formadores falam de si (entramos assim nas histórias particulares - sempre institucionais - de um grupo de formadoras).

Acompanhamos, nos capítulos iniciais, desenhos tecidos historicamente para o lugar do educador e seu formador e que foram caracterizados a partir dos recortes escolhidos. Tais desenhos apresentam uma composição e uma qualificação (no sentido da caracterização) a respeito desses lugares que foram e são historicamente oferecidos para os personagens em relação na prática institucional da formação continuada de educadores. A pesquisa vai procurar identificar como o cenário da formação e os lugares do educador e do seu formador são desenhados nos discursos dos participantes. Como se veem e como habitam tais lugares através das práticas institucionais concretas que fazem diariamente.

\section{5 - Desafios e exercícios: a distância da pesquisadora do seu campo de pesquisa e a análise institucional do discurso em grupo}

Desde as primeiras discussões deste projeto, quando ele era apenas um rascunho, uma questão esteve sempre presente: será necessário um exercício de distanciamento da pesquisadora em relação aos participantes da pesquisa, já que estiveram juntos em trabalhos anteriores.

Em busca das possibilidades de fazer AID em contextos como este, encontramos inspiração no trabalho de Lerner (2004, p.29), que fez sua pesquisa na instituição em que trabalhava. Ele diz: "O risco que se colocou desde o começo foi o de sua pertinência como agente torná-lo familiarizado com o discurso institucional a ponto de, tomando-o como natural, ficar impedido de analisar as determinantes institucionais". Esteve atento ao longo do trabalho às limitações impostas por tal fato em sua capacidade de análise, ato que segundo o autor implica em estranhar e suspender os sentidos. Considera que: "o estranhamento analítico deste pesquisador revelou-se parcial, o que está de pleno acordo com a concepção de que matrizes institucionais cumprem um papel importante nas determinações subjetivas, 
embora não as esgotem: daí a possibilidade de transitar entre as posições de agente e analista" (LERNER, 2004, p. 29).

Ao final do trabalho, Lerner (2004, p.265) conclui: "ser possível conduzir uma pesquisa das configurações discursivas de que se é parte".

$\mathrm{Na}$ experiência da atual pesquisadora o exercício de estranhamento e da suspensão de sentidos foi crucial e poderá ser acompanhado nas análises que se seguem. $\mathrm{O}$ fato de a pesquisadora ter uma relação estabelecida anteriormente com as integrantes da pesquisa trouxe dificuldades para a análise e condução das sessões e exigiu o exercício constante do distanciamento, pois ao longo desses anos de relacionamento foi constituído um modo de relação, expectativas mútuas, delineamentos de lugares a partir do qual falamos uns aos outros e compartilhamento de saberes, o que influenciou a atual produção. Em muitas situações, como veremos na análise, constituímos um grupo fechado, com um código próprio de comunicação ou partilhando pressupostos (saberes antecipados). Como disse Foucault na Ordem do Discurso (2000, p.53) enquanto discutia seu método de trabalho, estivemos atentas a: "não transformar o discurso em um jogo de significações prévias". Podemos dizer de antemão que tal exercício foi vivido com a ajuda da análise institucional do discurso feita em cima do material coletado nas sessões em parceria com a equipe de estudantes e pesquisadores do grupo da professora e livre- docente Marlene Guirado. Mas, o distanciamento não foi o único obstáculo enfrentado, nas análises das duas primeiras sessões fez-se presente mais um: conduzir o grupo de pesquisa a partir da AID.

Na ocasião da realização das sessões de grupo (2007) um material escrito serviu como inspiração para a construção do lugar da pesquisadora: foi um recorte de uma supervisão institucional feito por Marlene Guirado num hospital, para uma equipe multidisciplinar ${ }^{27}$. Tal material foi lido e relido pela pesquisadora em busca de construir uma referência interna que funcionasse como uma cena genérica (um quadro geral que indicasse o como se faz a AID em ato e em grupo). Embora o gênero de discurso produzido quando se trata de uma "supervisão institucional", seja bem diferente das "sessões em grupo para uma pesquisa acadêmica", encontramos na condução da mediadora do grupo alguns elementos que funcionaram como possibilidades a serem experimentadas e reconstruídas, como: deixar o tema da conversa "livre" para esboço de alguma demanda, ajudar o grupo a configurar uma proposta de trabalho, apontar discrepâncias entre o que se diz, pedir mais dados e descrições de cenas

\footnotetext{
27 O caso Clóvis pode ser encontrado em Guirado 2006 ( p.124 - 134) ou quando foi retomado em 2009 (p. 233-243).
} 
concretas, apontar as repetições e recorrências, fazer intervenções para mostrar os procedimentos institucionais (legitimação de um modo de fazer), construir cenas a partir do escuta do posicionamento dos personagens, e mobilizar os "pontos cegos", como fez Guirado (2009, p.238) no caso Clóvis: "um serviço que atende sem atender", "Clóvis, esse ilustre desconhecido". E por fim um exercício que me pareceu o mais difícil de ser feito em ato: "configurar os lugares imaginários que as pessoas se viam ocupando e os que atribuíam aos demais enquanto falavam” (GUIRADO, 2009, p.239), exercício que exige atenção, distanciamento para a análise e a colocação de novas expectativas que abram possibilidades de configuração de novos lugares.

As referências acima ajudaram a construir as quatro sessões em grupo feitas no ano de 2007 e as referências que elenco a seguir ajudaram nas análises finais do material organizadas em 2010.

Ricardo Barreto (2009), um colega do grupo de pesquisa, em seu trabalho de doutorado, demonstrou a possibilidade de fazer a AID em ato, num grupo de pesquisa com dentistas. $\mathrm{O}$ autor buscou marcar cenas e posições dos participantes em relação inclusive com o pesquisador, e com isto mobilizou os reconhecimentos e desconhecimentos nas relações entre dentistas, pacientes e acompanhantes. Considerou a AID um método fértil para investigação psicológica em grupo e apresentou o passo a passo dessa construção.

A partir do trabalho do autor, ganhamos mais algumas balizas procedimentais que foram descritas, tais como: marcar as repetições, os estranhamentos, as expressões verbais, as metáforas, os intervalos, a ironia. Sobre a ação do mediador, Barreto $(2009$, p.59) diz que faz pontuações, questionamentos e confrontações ao longo das sessões: "foram adotados recursos discursivos diversos como espelhamentos, sínteses, reorganizações analíticas, comparações de cenas e/ou dimensões do dizer, apresentação de hipóteses interpretativas dos movimentos discursivos na evolução dos encontros e o que elas produziam de efeitos nas interlocuções em grupo".

O autor complementa: "os encontros aconteciam com uma rede de posicionamentos e relações produtores de sentidos na ordem institucional do discurso, sendo feita a análise que nos foi possível em ato, por meio de uma escuta flutuante atenta às condições institucionais do discurso e aos efeitos de subjetivação" (BARRETO, 2009, p.59).

Evidenciou também, o que foi evitado em seu percurso, o que por oposição, busca dizerse através do que não é: "não partimos do pressuposto do que seria uma boa relação profissional-paciente-acompanhante na área estudada. Procuramos deixar, no reconhecimento 
de nossas intenções, em aberto o espectro dos efeitos de nossa análise" e "não pensamos em estabelecer posições bem definidas a priori para o pesquisador e as participantes da pesquisa, legitimando a repetição de um fazer psicológico em grupo, muitas vezes pautado no modelo clínico". (BARRETO, 2009, p.59).

Na discussão final do trabalho, Barreto (ibidem, p.173) realiza que a AID exercitada em sessões de grupo "não se assenta no mimetismo do lugar (ou suposto não lugar?!) convencional do psicanalista". Salienta que ocupou diversas posições nos discursos e que usou recursos da psicanálise como fazer perguntas, contraposições, direcionamento de temáticas, entre outros já apontados nos procedimentos da pesquisa.

Um momento caracterizado como zona de tensão foi a passagem da demanda do pesquisador pelos encontros para sua pesquisa, para a produção de demanda das dentistas, possibilitando que o pesquisador fizesse uma torção da posição de demandante para o de analista de demanda.

Outro ponto importante de ser destacado para nosso trabalho é o que diz Barreto sobre o trabalho em grupo (2009, p.182): "trabalhamos com as relações institucionais em grupo sem qualquer transcendência ao que nelas se constrói, sem substancialização ou teoricismo do que é um grupo antes que ele aconteça". E continua: "o grupo pode ser pensado como uma instituição social, não tendo uma realidade em si, já pronta, à espera das teorias desveladoras de sua natureza" (idem, ibidem, p. 182).

Demarcados o contexto relacional da pesquisadora com o grupo pesquisado, as características da pesquisa, os conceitos-referência para um modo de pensar e fazer, as influências e obstáculos vividos ao longo das sessões do grupo, organizamos agora, ao final do capítulo, os procedimentos adotados nas análises.

\section{6 - Procedimentos que orientaram as análises}

Analisamos no discurso das educadoras o seu modo de produção, o como ele se deu. Para isto, não desconsideramos o que disseram (o dito e os conteúdos), mas chegamos nos sentidos ao colocar atenção no movimento do dizer, ao como disseram, numa análise mais descritiva (tomada em oposição a uma análise mais interpretativa). Para tal, observamos as ênfases, as exclusões, as repetições, o tipo de interlocutor criado (lugares ocupados e 
atribuídos), as expectativas que apareceram nas relações, o como se organizaram as posições das pessoas, as oposições que apareceram, o que se legitimou como verdade. Ao mesmo tempo observamos as condições de produção daquele discurso, ou seja, o que o discurso da mediadora-pesquisadora em relação com as participantes produziu.

Trabalhamos cada sessão fazendo anotações após cada fala, numa tentativa de descrever os movimentos da sessão e de identificar os aspectos levantados acima. Depois, procuramos trabalhar o conjunto das quatro sessões, tomando os movimentos relacionais, procurando as regularidades, os estranhamentos, os jogos propostos, esboçando a cena da formação tal como imaginada e descrita, procurando ao final, a singularidade produzida.

Como o método nesta concepção é entendido como estratégia de pensar, partimos do princípio de que o resultado foi determinado pelo jeito com que trabalhamos: isto pode ser entendido como condição de possibilidade.

Nas sessões de grupo, a pesquisadora foi mediadora dos diálogos entrando num jogo de lugares que são atribuídos e assumidos em que cada parte usa os direitos que lhe são dados pelo outro e pela forma de diálogo convencionada no gênero de discurso "sessões em grupo", imaginado e atuado a partir de experiências anteriores a respeito deste lugar social e determinado por regras.

Com tais recortes conceituais e procedimentais produzimos as análises. Esses são os limites concretos desta produção. Vamos agora conhecer as "falas de si" de um grupo de educadoras-formadoras. 


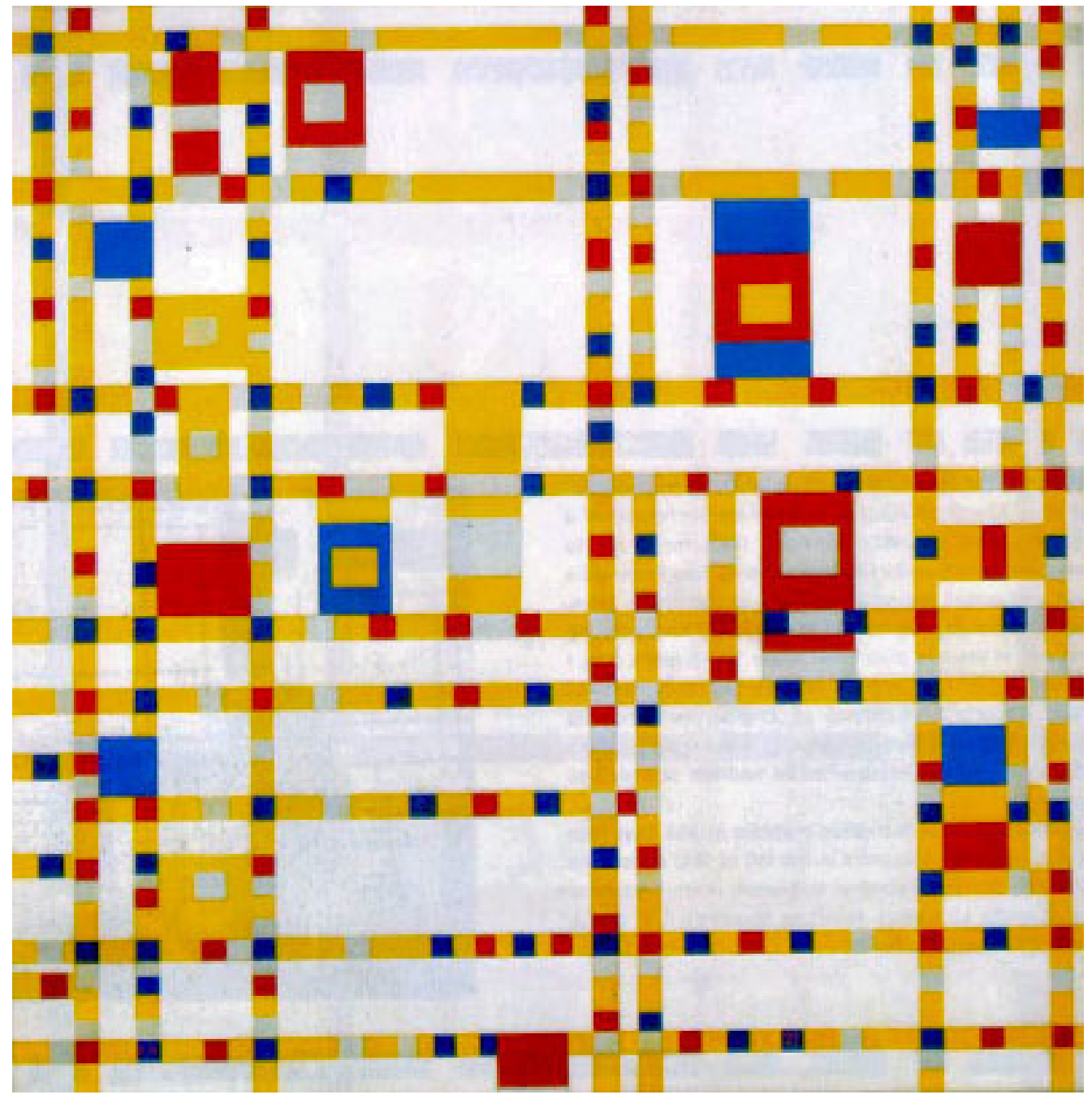

Fonte texto visual: Piet Mondrian. Broadway Boogie Woogie. 1942. 


\section{5 - AS SESSÕES DE GRUPO: UMA ANÁLISE}

A análise, desde a primeira sessão, presentificou um duplo desafio: a pesquisadora teria que buscar alguma forma de distanciamento das experiências passadas nas quais trabalhou com as pessoas presentes, agora reunidas neste novo grupo, encaminhando a nova proposta de falarem sobre as práticas atuais, para um trabalho de pesquisa. A primeira dificuldade foi fazer com que esse novo grupo não funcionasse "como se fosse" ainda o grupo anterior, chamado de grupo da coordenadoria, que diferencio neste trabalho grafando-o como Grupo 1, "esquecendo" que a proposta e o contexto agora eram diferentes. O fato de a proposta ser diferente, de haver agora uma demanda da pesquisadora não provocou de início o estranhamento esperado, o grupo funcionou no começo "como se" estivesse num encontro para mais uma proposta de trabalho como foram as anteriores. A intimidade foi restabelecida com rapidez e o distanciamento da mediadora-pesquisadora que intencionava não ficar no lugar conhecido foi atravessado pela história que construiu com o Grupo 1. O lugar da pesquisadora-mediadora atual nesse novo grupo foi constituído, também, pelo lugar ocupado no passado quando fez a coordenação do Grupo 1 e ajudou seus membros na construção de políticas e práticas de formação de educadores e depois, a reinventar os seus lugares nas escolas onde foram trabalhar em seguida.

O outro desafio foi fazer a análise institucional do discurso em ato e depois, no texto produzido e taquigrafado da sessão, fazer uma segunda análise e com ela tentar reorientar a sessão seguinte, e, assim, chegar até a quarta e última sessão. Em alguns momentos, isso foi alcançado, em outros, não foi conseguido como demonstram as análises que se seguem.

\section{1 - Primeira sessão}

$\mathrm{Na}$ abertura do primeiro encontro, a pesquisadora, agora como mediadora do grupo, fez a seguinte fala: 
A ideia é que falem livremente, sem pauta nem estudo prévio. Vamos conversar sobre a prática de formação de vocês tá bem? As minhas perguntas também não estarão previamente em meu planejamento, irei formulando-as na medida em que for vivendo e sentindo as conversas com vocês, ok? O material...ele será analisado tendo como método a análise institucional do discurso, já expliquei um pouco pra vocês né...e...a qual certamente, me inclui. (mediadora, s 1).

Neste começo podemos observar nas palavras "sem pauta nem estudo prévio"; "não estarão previamente em meu planejamento"; uma proposta de diferenciação em relação a "algo" que elas pareciam conhecer e assim compreender; com a negação a mediadora traz para a cena atual a referência dos trabalhos anteriores. Em seguida, a mediadora faz o histórico de todos os trabalhos anteriores dos membros desse grupo com ela de 2003 até 2006 e a proposta para que falem de como está o trabalho de formação delas hoje e também da formação que recebem. Vejamos como a mediadora continua:

Eu gostaria de começar tentando fazer um histórico dos trabalhos que já fizemos juntas ao longo desses anos. Começamos com o grupo da coordenadoria. Então, depois, para lembrar um pouco, em 2005, quando acabou a gestão da prefeita, vocês me procuraram e fizeram a proposta de trabalharmos em grupo discutindo as dificuldades dessa transição, na prática, e nós elegemos alguns temas de estudo e reflexão. Escolhemos alguns autores para estudar, para ajudar a pensar essa situação. Em 2006 foi um trabalho um pouco diferente. Trabalhamos de junho até novembro, a ideia era conversar sobre como trabalhar com a liberdade e o inventar-se a si mesmas a partir das dificuldades e das políticas públicas propostas pela nova gestão. Em 2007, quando decidimos nos encontrar no começo do ano, surgiu a ideia de trabalhar com publicação, ou rever uma publicação antiga ou produzir uma publicação nova em grupo. Depois disso, acabei não podendo continuar com vocês, vocês tiveram mais alguns encontros e em julho vocês me chamam para encontrar com vocês mais uma vez e cada uma contou os desafios, as novidades, o que estavam vivendo na prática. A partir do que eu escutei de vocês, propus alguns encontros de reflexão que eu pudesse usar, esse espaço de produção de reflexão, para um trabalho de pesquisa meu. Então, aí, até conseguirmos organizar toda essa idéia, já era outubro. Eu fiz as entrevistas individuais com cada uma pedindo que me contassem uma semana de trabalho de vocês, né, depois marcamos os encontros de grupo.

Eu queria situar vocês numa temática que eu vi retornar em nosso último encontro grupal e que me motivou a pesquisar o lugar do formador de educadores e eu queria que vocês me contassem um pouco como é que vocês estão vivendo essa temática hoje, como é que vocês estão em relação a isso hoje. Então, a ideia é que vocês me contem um pouco daquela sensação de pouca produção, da queixa que vocês trouxeram diversas vezes de 2005 pra cá, uma sensação de repetição dos mesmos conflitos, das mesmas dificuldades na situação de trabalho. Algumas pessoas, em momentos diferentes, viveram uma situação pessoal de depressão, de desânimo com o trabalho, de muita dificuldade de encontrar um caminho, para trabalhar com as suas equipes, para superar as dificuldades, os conflitos que eram recorrentes e voltavam de diferentes formas, e, também uma sensação de morosidade nas mudanças, e, permeando tudo isso, a questão da gestão da política pública. 
Vamos pensar um pouco sobre isso, vamos olhar para isso, vamos conversar um pouco dessas práticas de vocês e das dificuldades no trabalho? Como está isso hoje? (mediadora, s.1).

Ao trazer a cena anterior dos grupos passados, a mediadora reconstitui as parcerias, a superposição das cenas (anterior e atual) e presentifica o fato de que as condições de relação atual com ela passariam necessariamente pelas relações tais como foram estabelecidas nos anos anteriores. Neste sentido, as repetições e uma certa estabilidade de posições dos parceiros, e de expectativas, e de temas de conversa, bem como as novidades que a situação de pesquisa poderia trazer, tomaram como referência a história relembrada pela mediadora. Compreendendo a atuação da mediadora como parte da produção dos discursos, observamos que oferece ao grupo a condição de atualização da demanda: a edição do novo campo relacional, agora em cima da pesquisa e cuja demanda partiu inicialmente da mediadora, se fez a partir da história anterior que é resgatada a partir da experiência do passado (relembrada pela mediadora). Os conflitos e queixas presentes na relação anterior com a mediadora são então convidados a serem reeditados e repensados, agora no momento presente. A primeira participação depois da fala de abertura foi de Sílvia:

Acho que para falar de hoje a gente tem que voltar um pouco lá pra trás. A gente sai da coordenadoria de um grupo extremamente produtivo, com muitas lideranças, mas com lideranças que se complementavam, um grupo muito reflexivo, muito idealista, muito sonhador, então, e... que nos encontramos num determinado tempo histórico. Para a nossa felicidade nos encontramos com todos os nossos sonhos e deu muito certo. Foi um grupo que se entendeu, que produziu, que trabalhou, que fez e foi muito forte o que viveu, o que a gente fez junto. E saí daquele movimento intenso de vida, de trabalho, de muito trabalho e entro numa escola paralisada, estacionada, um grupo extremamente resistente, um grupo que sabia que eu estava vindo de uma coordenadoria para complicar mais a situação, que carregava uma bandeira, é claro, e foi uma cacetada na minha cabeça sair de um grupo de vida e entrar num grupo de morte. (Sílvia, s.1).

A primeira fala da mediadora conecta o fio das experiências passadas a esta, o que é confirmado por Sílvia que propõe retroagir trazendo em seguida Grupo 1. A experiência vivida no Grupo 1 é crivo para comparação com outros grupos de trabalho, "sair de um grupo de vida e entrar num grupo de morte”. Sílvia aceita o convite para relembrar e retoma um tema que é composto de uma crítica com tom de queixa: "entro numa escola paralisada, 
estacionada, um grupo extremamente resistente" e que "foi uma cacetada na minha cabeça" (s.1).

Observamos que o movimento inicial começado por Sílvia deu o tom para a primeira sessão do grupo: colocar as experiências atuais em oposição à vivida nesse Grupo 1. De um lado, ficaram as boas lembranças do Grupo 1 e do outro, cenas do trabalho atual, caracterizado através de indignações, queixas, conflitos e reclamações, o que a colocação inicial da mediadora ajudou, também, a reavivar, pois nela já se apresentaram algumas oposições (depressão-liberdades, etc.).

Mais falas mostram o quanto o Grupo 1 ocupou a sessão como um cenário sempre presente: "Acho que esse momento da gente ficar um pouco, que foi mais o ano de 2005 que a gente ficou um pouco naquele movimento de luto, se é assim que a gente pode chamar, ele foi aos poucos, pelo que eu estou vendo cada uma falar aqui, foi trabalhado por cada pessoa de uma maneira diferente" (Paula, s.1).

O movimento de reedição de lugares relacionais anteriores, pode ver visto também através da entrega do grupo, da tranquilidade, na não preocupação com a taquígrafa, que não é em nenhum momento citada. O mesmo ocorreu com o gravador ali presente, que, embora contextualizando um cenário de pesquisa, também não foi comentado. A sessão de grupo foi tratada com uma confiança e proximidade que foi estabelecida a partir das relações do passado.

A comparação que opõe aparece na fala de outras educadoras-formadoras e ao longo de toda a sessão como podemos ver: "então, a gente percebia o quanto a coordenaria que a gente estava tinha avançado frente a essa coordenadoria. As coisas não tinham mudado, continuavam do mesmo jeitinho" (Rita, s.1) e em seguida:

Desde o começo quando eu voltei, eu percebi que esse grupo era difícil. Por exemplo, nos horários de $\mathrm{JEI}^{28}$, elas brincam, brincam, brincam e na hora de a gente trabalhar elas não querem. Então, se for estudar alguma coisa, ela reclamam, se vai fazer alguma coisa escrita: ah, não, não sei o que, dizem, e sempre procuram me enrolar, essas coisas assim. (Rita, s.1). 
E ainda: "Aí, o que aconteceu? Num desses itens do plano, a gente tinha resgatado as reuniões como nós fazíamos na coordenadoria”. (Paula, s.1).

Parece um consenso do grupo, pois todas em algum momento fazem tal separação, comparação, crítica, o que vai ocorrer com regularidade e que podemos ver mais uma vez, agora na fala de Amanda: "Mas a Coordenadora Pedagógica não entrava na formação” (...) "em relação à Coordenadoria e eu chegando e ocupando o espaço de formação porque eu acreditava e acredito numa outra concepção de coordenação e eu fui trazendo para eles, fui discutindo com eles, então, foi complicado sim” (s.1). E mais uma vez com Clara:

Eu fiquei muito tempo me culpando por isso. Eu dizia: eu não expliquei direito. Aí, eu voltava nos registros, olhava e falava: meu Deus, será que eu não passei para o grupo da tarde, será que eu não passei para um, para outro? Eu buscava muitas falhas em mim quando eu percebi que era um movimento do grupo e, aí, eu comecei a cutucar as pessoas no dia-adia: eu não falei isso para vocês? Mas estava no nosso registro, gente, isso foi passado, vocês assinaram. Você mesma fez o registro, então, você sabia. E comecei a discutir muito essa questão. Mas que é uma tortura diária, realmente, é. [...]

Acho que caminha muito pela questão do compromisso. As pessoas, elas não assumem o compromisso, o compromisso político, o compromisso social, não colocam a mão na massa. É aquela coisa assim: eu finjo que trabalho, você finge que acredita. Com o grupo da coordenadoria isso não acontecia, a gente não fingia que trabalhava, a gente trabalhava mesmo, defendia o que acreditava, cada um falava o que pensava, mas a gente punha a mão na massa. Na escola pública, isso acontece muito ... das pessoas fazerem de conta. Faz de conta que registra, faz de conta que tem diário, faz e conta que a festa junina é legal, faz de conta que todo mundo quer isso. (Clara, s.1).

Nesta fala de Clara percebemos que ela também coloca o Grupo 1 num lugar positivo, e a prática atual num lugar "torturante", o que concretiza a oposição.

No primeiro trecho de sua fala, Clara mostra em seu discurso uma expectativa com o registro, como se o ato de ler, escrever ou assinar fosse garantia do apoio à sua condução dos trabalhos como coordenadora-formadora. Clara diz: "você sabia", ou seja, o interlocutor escutou a informação, escreveu, assinou e mesmo assim não atendeu a expectativa da formadora. Esse descompasso entre expectativas parece diário e é descrito como algo muito ruim, que não poderia ocorrer, gerando indignação, procuras por falhas em si e depreciação.

No segundo trecho, Clara opõe os que fazem e os que não fazem ou fazem de conta. Aparece aqui um elemento que aponta para uma posição política na oposição de lugares: de 
um lado estão os que têm compromisso, descrito como compromisso político-social, que são aqueles que trabalham, falam o que pensam de fato e defendem algo que acreditam. O Grupo $l$ é identificado como estando deste lado, o que de certa forma convoca a mediadora para junto delas. Do outro lado são posicionados os que não têm compromisso e "fazem de conta" que estão de acordo e que trabalham na mesma direção "acordada" no grupo de trabalho. Essa posição de fingimento é descrita como comum "na escola pública".

Sílvia continua:

Nós éramos da equipe pedagógica da Educação Infantil. Era uma coisa de muita produção e as pessoas viam a produção, a gente atuava o tempo inteiro, a gente fazia cursos, a gente entrava no $G A A E^{29}$, eu entrava com supervisão na JEI. Era uma coisa de muita responsabilidade e isso assustava as pessoas. Eu sei que assustava. Isso amedrontava, era uma coisa assustadora, puxa, como elas trabalham! Porque elas falavam para mim: a gente admira você, a gente concorda com a sua concepção, a gente sabe que você é competente, mas a gente não quer trabalhar com você. Eu falo: mas eu não entendo isso. É muito interessante. (Sílvia, s.1).

Sílvia parece concordar com Clara e acrescenta novo elemento na oposição: de um lado elas, as que trabalham, produzem, atuam, fazem curso, dão supervisão, tem responsabilidade e do outro, as que se assustam e que não querem trabalhar com elas. $\mathrm{O}$ recurso que ela usa de dramatizar a fala de suas educadoras convida à adesão com relação ao seu argumento.

Observamos em seguida às oposições, uma regularidade na maneira como se referem aos educadores que recebiam a formação delas: "grupo muito difícil de trabalhar" (Sílvia, s.1), "também tem essa questão da desvalorização total essa coisa do ser professor que não é olhado, elas nunca tinham visto devolutiva na vida delas. Elas não sabiam o que era isso, o que era um coordenador junto na parceria” (Sílvia, s.1), "Elas não querem responsabilidade porque isso traz uma responsabilidade. Você decidir junto você reparte a responsabilidade e quando o outro te diz: faça assim, e, se não der certo, você tem culpabilidade sozinha" (Maria, s.1), "Mas isso não rola só em Educação Infantil. No Fundamental, o discurso é

29 GAAE - grupo de acompanhamento da ação educativa das escolas feita por profissionais da coordenadoria 
esse. A maior briga no Fundamental é essa de fazer o professor acreditar no aluno"(Amanda, s.1), e ainda:

E tem outra questão que é assim: você está numa escola pública, qualquer coisa serve e tem uma questão de se trocar tempo por dinheiro. Tem professores que têm competência para fazer, mas não fazem. Não fazem porque não querem fazer porque estão acomodados numa situação muito cômoda de trocar tempo por dinheiro. Eu vou lá passar o tempo da criança (Sílvia, s.1).

As falas destacadas atribuem ao educador que recebe a formação um lugar de faltas, de dificuldades ou qualidades negativas (fingidos, descompromissados, enroladores, reclamões, assustados, descrentes, acomodados etc.). No trecho acima observamos o uso do discurso indireto livre, Sílvia mistura o narrador com o personagem, produzindo um efeito de aproximação da personagem, o narrador confunde-se com ela, transmitindo a impressão de que ambos concordam e falam em uníssono. As duas vozes que poderiam mostrar posições subjetivas diferentes são fundidas, enfatizando a verdade anunciada. Sílvia apresenta o educador que troca tempo por dinheiro, só tem interesse no dinheiro e não no trabalho que até teria competência para fazer, e não faz por comodidade, porque não quer fazer e isso acontece na escola pública. Esta posição de não fazer ou fazer qualquer coisa por estar numa escola pública, faz do professor um capitalista e não um idealista "que acredita no que faz". Mais uma vez, a oposição de lugares políticos aparece dispondo os lugares da instituição, de um lado os que têm uma missão educativa e social de outro os que querem dinheiro. Isso também divide os lugares neste grupo: do lado do compromisso todos do grupo e do outro lado os "de outra doutrina”.

Em alguns momentos os educadores aparecem em outra posição, valorizados em seu aspecto e potencial: "Mas elas tinham tanto pra dar" (Sílvia, s.1), "Eu sei que o outro grupo resolveu e isso foi muito bom. Chuta a porta, fala, grita, sei lá, mas reage, faz alguma coisa porque a hora que as pessoas se colocam, você consegue intervir, você consegue estabelecer um diálogo. Então, isso tem sido muito bom. Acho que é um amadurecimento para o grupo e para a gente” (Clara, s.1), “Aquele ano foi bem interessante porque a gente foi propondo um monte de coisa e foi conseguindo provar que a participação dos pais e da comunidade era importante, que os grupos trabalhando juntos era importante e produziriam alguma coisa" (Maria, s.1), "Então , para mim a questão está: onde está o desejo dessas pessoas, onde elas 
estão botando as energias delas? Porque energia têm”. (Letícia, s.1). A aproximação é possível quando a transformação pelo trabalho de formação acontece. Percebemos nos trechos acima momentos de "trégua" nos quais as educadoras recebem qualidades positivas e são valorizadas, ou o trabalho com elas é valorizado. Mas o mal-estar que é conviver numa escola com pessoas de partidos e concepções diferentes de trabalho é presente e permanece como pano de fundo da cena da formação continuada nas escolas municipais de São Paulo, como podemos ver no seguinte diálogo:

Sílvia - Não é porque não sabe fazer, é porque não quer.

Leticia - Mas a experiência minha é de parar um pouco de julgar.

$$
[\ldots]
$$

Sílvia - As outras não participaram porque não se dispuseram. Isso é comum na prefeitura.

Maria - Elas têm concepção diferente, é só isso.

Há uma tentativa de ocupar uma posição que evita o julgamento dos "outros", permitindo a eles que tenham concepções diferentes, mas as "lutas que se travam" no contexto relacional que permeia a formação continuada em serviço na prefeitura são muitas. Há no discurso delas certa generalização, percebemos que em cada momento trazem um educador ou um grupo diferente, mas que são amalgamados e indiferenciados sob o título de resistentes: "Mas eu não sei dizer a que esse grupo resiste. Eles querem fazer da maneira deles". (Rita, s.1). "Então, a resistência não está só na proposta, está na dificuldade de fazer". (Letícia, s.1). "Essas pessoas foram embora, as mais resistentes não conseguiram ficar. Eu estava disposta a trabalhar com elas porque acreditava que elas eram competentes, não era falta de competência. A questão era outra. [...] Uma coisa subjetiva delas de não conseguir lidar com as faltas delas". (Sílvia, s.1), "Quando eu entrei, eu cheguei em 2005 junto com a Bê, a gente tinha um trabalho juntas e tal e, aí, a gente teve que bancar muita coisa, sim, porque quando a gente chegou já tinha uma postura de resistência” (Paula, s.1).

Ao longo da sessão, essas nomeações foram tão repetidas que acabaram parecendo naturais, coladas às pessoas que estavam do outro lado, recebendo a formação. $\mathrm{Na}$ fala de 
Paula, a postura de resistência parece inerente: "já tinha uma postura de resistência”, antes mesmo de elas chegarem à escola nova. A resistência aparece ao lado "deles" ou "eles" e as palavras que ajudam a qualificá-la são: "faltas", "dificuldade”, “foram embora, não conseguiram". Em oposição ao "eles" está o "eu”, logo transformado em "a gente" e as ações que colocam este sujeito em movimento são "tinha um trabalho", "teve que bancar muita coisa", "estava disposta a trabalhar".

O termo resistência aparece na fala delas como algo pejorativo, por romper com algo que ia bem, que era "legal": "Então, a resistência já começou daí. Estava tudo num movimento muito legal, estava tudo caminhando do jeito que elas queriam e, aí, vêm duas pessoas e rompem com isso. Então, a impressão que a gente tinha é que elas estavam prontas para resistir e era isso mesmo". (Maria, s.1). A perspectiva com que o grupo trata o termo deu ao mesmo um lugar a priori e negativo: a resistência como obstáculo que deve ser transposto através de intervenções e do trabalho grupal. Ela poderia ter sido vista positivamente no sentido de produzir algo, mas foi mostrada como estagnação, como algo ruim a ser extirpado, do lado das educadoras que recebem a formação. Ninguém estranhou essa construção que foi produzida em consenso ${ }^{30}$.

Vejamos mais umas falas sobre a resistência: "a resistência está muito vinculada à hierarquia também” (Letícia, s.1), "essas coisas existem em todas as instâncias, não tem pra onde fugir” (Sílvia, s.1), "Mas a gente defende alguns princípios, algumas concepções. Acho que a resistência, ela vem aî”. (Letícia, s.1). A resistência é tema de conceituação pelas participantes: ela existe quando tem hierarquia, tem em todas as instâncias e faz frente a princípios defendidos. Isto mostra, no discurso, uma relação de exterioridade com a resistência.

Agora a seguinte fala de Sílvia:

Eu posso até dizer que era um grupo muito difícil de trabalhar e hoje olhando isso, esse é o meu terceiro ano aqui, o primeiro ano foi muito difícil, mas eu tenho muito orgulho

$30 \quad$ Falar com a mediadora sobre temas e conceitos estudados junto com ela anteriormente (resistência), ofereceu índices para a verificação da veracidade científica dos fatos relatados. Mais uma vez a cena dos grupos passados e a presença de pressupostos teóricos comuns entre o grupo e a antiga coordenadora compareceram e não só, supostamente, facilitaram a comunicação, como garantiram uma consistência acadêmica. 
do que eu consegui construir. Eu olho e falo que o primeiro ano foi difícil, mas acho que eu consegui segurar a peteca, lidar com os conflitos do meu jeito, à custa de muito sofrimento, mas consegui permanecer aqui. Hoje, no terceiro ano, as coisas estão tão diferentes, é outro grupo porque esse grupo que existia, ele foi se desfazendo, se transformando porque algumas coisas não ecoavam entre nós todas.

\section{$[\ldots]$}

Foram rupturas. Essas pessoas foram embora, as mais resistentes não conseguiram ficar. Eu estava muito disposta a trabalhar com elas porque acreditava que elas eram competentes, não era falta de competência a questão. A questão era outra.(s.1).

Encontramos em meio ao discurso da resistência uma caracterização da ação formativa delas: um jogo entre formar (influenciar) e resistir à formação (ação-reação das professoras). Formar é algo que é construído, que dá orgulho, que busca vencer as resistências, transformar as pessoas. É algo difícil, que lida com conflitos, há sofrimento, há resistência da parte da formadora também no sentido de "conseguir permanecer" (nesse sentido uma resistência produtiva), de insistir. O processo de formação é algo que desfaz o grupo inicial, pois as mais resistentes, ou seja, aquelas com as quais não foi possível demolir a resistência, acabam por deixar o grupo. Interessante que a resistência das pessoas que foram embora não parecia ser técnica, pois elas "eram competentes", daria então para trabalhar com elas, para "influenciar". O motivo então seria de outra ordem ou questão. No momento em que a mediadora pede para Sílvia definir a questão, aparece:

Sílvia - Uma coisa subjetiva delas de não conseguir lidar com as faltas delas. Elas não conseguiram lidar com isso, não conseguiam e eu não sabia também o que é que eu fazia. É muito interessante porque não houve um enfrentamento direto. Nunca houve discussão aquela coisa de uma tratar mal a outra. Jamais. Só que era um silêncio. Eu entrava, era um silêncio. Na festa junina, um grupo veio vestido de preto. Eu levei um susto e perguntei: por que vocês estão de preto? Então, era esse tipo de coisa que acontecia.

Mediadora - E por que você acha que elas vieram de preto?

Silvia - "Porque a gente não concorda com essa forma que você encaminha a festa junina”. Eu perguntei: por que vocês não falaram isso, então? Por que no processo de construção vocês não colocaram a forma que vocês gostariam? Elas recebiam as coisas de uma forma como se eu estivesse mandando fazer. Cumpra-se.

Clara-É o silêncio.

Rita - Talvez, elas estivessem acostumadas com isso.

Silvia - Exatamente. Estavam acostumadas. E eu colocava: o que vocês pensam disso? 
Rita - Elas não te conheciam para poder diferenciar a postura. (trecho, s.1).

A questão apresentada por Sílvia é individual e responsabiliza o outro por "não conseguir lidar com as faltas delas" e a si também: "eu não sabia também o que é que eu fazia". As rupturas e saídas do trabalho são pelas "faltas, erros, problemas relacionais e individuais”. A dimensão da hierarquia autoritária aparece como uma característica da escola, lá a coordenadora manda e o professor cumpre ou "silencia" e faz resistência com atos que falam. Sílvia não reconhece ir de preto à festa como enfrentamento direto, nem como discussão, nem como tratar mal, mas é dessa forma que "falam" que não concordam com os encaminhamentos da coordenadora. A questão política aparece no fato de a coordenadora nova (Ś́lvia) ter sido da coordenadoria na gestão do prefeito anterior, e, portanto, conhecida delas por ocupar um cargo que definia e orientava políticas e projetos educacionais das escolas. No jogo da formação a resistência é associada ao "não conhecer bem a formadora", a tomá-la como "mandante" e não como "construtora" de processos, como alguém que quer de fato saber o que pensam e que pode levar isso em consideração nos encaminhamentos que faz. Assim Sílvia se reconhece. Letícia também ajuda a caracterizar o lugar do formador:

O objetivo, por exemplo, do desenho mimeografado eu vou pensar com a professora que a criança pode representar, que ela possa mostrar a sua subjetividade, o que ela pensa sobre o mundo. $O$ desenho mimeografado impede isso. Vem pronto, a criança não vai conseguir colocar o que ela pensa, enfim, vai um pouco nesse caminho. Agora, a intolerância não significa que não tem problematização, mas de procurar entender porque aquele desenho está ali naquele momento, da pessoa poder falar porque aquele desenho está ali naquele momento. Eu quero ouvir mais porque está tendo essa necessidade, até a pessoa me falar: "tem hora que eu não aguento mais, tenho que dar um desenho para acalmar". Então, na verdade, ela não está dando o desenho porque ela acredita no desenho, o desenho vem porque tem uma dificuldade de se relacionar com o grupo de crianças, do trabalho com os grupos menores que também vem a questão do desenho mimeografado.(Letícia, s.1).

A fala de Letícia sugere que sua ação formativa é fazer pensar, problematizar a posição da professora, colocá-la a dar até as suas razões: a professora dá o desenho mimeografado (que Letícia não concorda) para acalmar a turma, não por acreditar nele. Neste sentido, Letícia mostra que a argumentação a favor de uma concepção de trabalho também faz parte do trabalho do formador e que ela só "parou" a conversa com a professora, quando percebeu que não havia a necessidade de "ensinar" sobre o valor do desenho da criança, pois 
o uso do desenho mimeografado era mais um "não aguento mais" do que uma escolha conceitual. O foco da "formadora" muda então do desenho para a dificuldade da professora de se relacionar com o grupo de crianças. O uso de citação da fala da professora se faz presente no trecho acima, ajudando no convencimento do ouvinte.

Os temas da resistência e da formação continuam a aparecer enlaçados: "Elas se fecham no mundo delas, isso dificulta os demais grupos, mas a escola percebeu já isso e a diretora colocou que quem não estivesse satisfeita era pra entrar na remoção porque não ia ter condições. Aí elas entraram na remoção”. (Rita, s.1). Vemos que em momentos nos quais não há consenso possível há sempre a possibilidade de pedir a remoção do educador resistente ou dissonante. A formadora Rita usa a voz da diretora, é a diretora que fica no lugar de convidar a educadora que não colabora e que não entra no processo de formação, a sair.

Em alguns momentos vieram exemplos extremados que justificam a remoção da profissional "sem remorso" nenhum:

Acho que quando a Silvia traz essa questão do caos pedagógico, do caos na escola, eu presenciei algumas práticas no CEI, que pelo amor de Deus, tipo, a criança vai no banheiro e a professora limpa a criança com a própria descarga. A criança acaba de usar o banheiro e você, simplesmente, dá a descarga. Depois limpa a criança com a água da descarga (Clara, s.1).

E: "Para você ter uma ideia, existia um espaço de formação, pago pela prefeitura em que elas faziam artesanato na escola e elas ficavam tricotando". (Amanda, s.1).

Como formadoras, elas estão de um lado do vetor de forças, trabalhando para que os outros mudem naquilo que julgam que precisa ser melhorado. Letícia traz mais elementos para pensar nesse jogo de forças, usando mais uma vez o discurso indireto livre, indiferenciando narrador e personagem:

Aí, passa por uma coisa também, a gente acha assim: nós podemos resistir porque, eu fico olhando, às vezes, o professor não tem argumentos teóricos, mas ele tem uma prática também lá e que ele não consegue muito organizar. Alguns professores conseguiram verbalizar isso para mim. A gente não consegue explicar como a gente quer fazer diferente. Você fala de um jeito que a gente fica sem saber. A gente sabe fazer isso. Então, isso também 
me fez pensar que tem uma questão do poder da palavra, do poder da teoria, do lugar do CP $P^{31}$. (Letícia, s.1).

Ela mesma fala mais pra frente: "Como é que você vai seguir uma orientação que você, absolutamente, não concorda? Aí, vamos pensar na nossa resistência diante do supervisor, dos cursos que nós estamos tendo hoje. Como é que você vai aceitar isso?”. (Letícia, s.1). Paula complementa:

Aí, essa questão da resistência é muito legal de pensar porque eu pensei: você também tem a resistência sua em relação a esse movimento institucional maior. Claramente. A gente fazia coisas que você estão falando que os professores fazem. A gente faz também. Quando você não concorda com uma coisa que está sendo colocada, você se cala ou você reclama ou você faz ao contrário. (Paula, s.1).

Os professores quando discordam, reclamam, fazem ao contrário ou se calam, são chamados de "resistentes". As formadoras também discordam, reclamam e etc. Onde estaria a diferença? Letícia, em sua primeira fala, reconhece que o professor tem um saber prático e que frente ao poder do coordenador com sua teoria e sua palavra, não consegue organizar, explicar. É como se a resistência dele ficasse então prejudicada sem o argumento teórico, e então, desvalorizada pelo formador. Deixa subentendido que elas, as formadoras, sabem resistir e têm argumentos teóricos: não seguem orientações que discordam. Fica marcada aqui uma posição política: as formadoras sabem da sua resistência e a exercem com as pessoas que ocupam cargos superiores aos delas ("diante do supervisor") como forma de "luta", também a usam, "claramente", ou seja, com consciência, para se opor ao "movimento institucional maior". A resistência, quando exercida pelo professor, não aparece de forma positiva no discurso delas, nem como consciência de uma luta por um saber que portam, mas como algo ruim, ligado ao não saber, a alguma "falta" que portam e que precisam trabalhar.

No lugar de quem recebe a formação da $\mathrm{SME}^{32}$, ou seja, do outro lado do vetor, poder discordar, pensar e fazer diferente, ter liberdade é o que pleiteiam, principalmente quando não 
concordam com a formação ofertada. Há uma identificação com os lugares de resistência em seu sentido positivo, quando ocupados por elas.

Depois descrevem como fazem essa resistência: "E ao mesmo tempo procurando algumas possibilidades de trabalhar de uma forma paralela a isso. São possibilidades ainda pequenas. Talvez, quando a gente faz uma reunião com as escolas para discutir outras coisas, coisas que a gente achou importante e não algo mandado pela administração Serra” (Paula, s.1). Nesse momento a questão da entrada do outro prefeito, o José Serra, fica nomeada e ligada ao formato de "mando". Interessante que em trechos anteriores falaram que as professoras da escola de Sílvia a esperavam com a expectativa que ela fosse autoritária, por estarem acostumadas a isso. Começaram uma relação nova com Sílvia a partir desta expectativa "de mando" somada ao que conheciam dela do lugar da Coordenadoria. Nesse cenário os jogos se deram. O mesmo se dá em relação ao "mando" de Serra. A administração Serra "manda" discutir coisas que este grupo não acha importante e tenta trabalhar de forma paralela a isso. Paralela é ao lado de e por isso não caracteriza necessariamente a oposição, tão discutida até aqui, mas um jogo no qual outras posições são possíveis para quem discorda do "mando".

Os cenários desenhados para as cenas da "formação" mostram confrontos e quebras de expectativas. $\mathrm{O}$ jogo de poder e as resistências nele presentes opuseram dois vetores de força: de um lado, alguém ou um grupo querendo formar, influenciar, promover mudanças; de outro, os que não aderem e oferecem resistência, criando uma tensão.

Letícia e Rita continuam a conversa: "Será que não é o tempo mesmo das pessoas aprenderem que jogadas podem fazer com cada um mesmo porque, quando você não conhece, você não sabe muito bem. Tem a questão da hierarquia também. Você pisa em ovos mesmo, no começo, tanto a gente como elas" (Letícia, s.1), e "Mas, de qualquer forma, pelo menos o grupo melhorou um pouco. Não digo que é um grupo gostoso por conta de uma pessoa que influencia os demais mas, de qualquer jeito, é um grupo que está fazendo" (Rita, s.1). E ainda:

É claro que, dentro disso, eu tenho lá grupos que ainda resistem e é muito claro que a resistência é contra quem ocupar aquele cargo ali. Não é comigo Maria, mas com quem ocupar o cargo de coordenadora ali ou quem ocupar o cargo de diretora ali vai ter a resistência daquele grupo porque tem um grupo que é simplesmente contra. (Maria, s.1). 
As falas acima mostram este grupo se conscientizando do "jogo" institucional: identificam os personagens, quem influencia quem, os cargos e suas expectativas (e os exercícios de poder que lhes é possível em cada momento), as separações (quem está de qual lado), e assim, "escolhem” suas posições. Este jogo porta uma instabilidade que o caracteriza: a cada mudança de administração (que ocorre a cada quatro anos) certos lugares ficam vagos e são ocupados por novos personagens, gerando todo um rearranjo que mobiliza muito todos os envolvidos. No trecho abaixo observamos alguns requintes do jogo:

Silvia - Algumas o ano passado já ligavam, lá, me ligam ainda. Outra veio assistir a reunião pedagógica. Ela me perguntou se podia assistir a reunião. Eu falei: claro.

Rita - De outra escola?

Silvia - De outra escola porque estava sem coordenação, estava sem orientação e precisava de uma reunião em que se produzisse. É muito interessante. Teve outra situação...esse concurso, esse último, e eu falei para as minhas professoras: vou montar um módulo de aula para vocês, para quem vai prestar o concurso. Vocês querem? Claro, claro. Eu queria dar uma força para elas. Das 10 que saíram, oito ligaram que queriam fazer o curso comigo. A minha assistente de direção falava: vocês não têm vergonha na cara? Vocês foram embora da escola e agora querem aula? Então, o que é isso? Eu quero o que você tem, mas eu resisto. Isso até hoje é uma incógnita na minha cabeça. Eu fico falando: O que é isso? Quer assistir reunião, quer ouvir, mas não quer estar aqui (trecho, s.1).

As professoras na posição de "coordenadas" não aceitavam a formação, mas na posição de "estudantes para um concurso", não só aceitam, como a demandam. Nesta fala, Sílvia apresenta a coordenadora formadora como aquela que sabe fazer reuniões, orientar professores, fazer o grupo produzir, conhece (sabe ensinar) os conteúdos que caem em concurso, e por isso, é valorizada pelos educadores do município e pela instituição (que define os saberes que serão exigidos no concurso). Isto é desejado pelas professoras do lugar de "convidadas", mas não do lugar de "professoras em formação continuada oficialmente daquela coordenadora". Quando as professoras participam da jogada, mas estando de fora do jogo da formação continuada em serviço, não há resistência, mas interesse em participar da formação (no caso, uma formação para o concurso).

A cena do jogo de forças é apresentada também como guerra: 
Então, a impressão que a gente tinha é que elas estavam prontas para resistir e era isso mesmo. Tudo que era proposto tinha uma coisa muito forte de "não vai dar certo, a gente nunca fez assim agora a gente tem que fazer?". E, aí, durante aquele ano a gente foi conseguindo provar para elas. Era um descrédito muito grande no trabalho com os pais, que é o que chamava a nossa atenção, no trabalho com as crianças e com as agentes escolares, que era assim, uma guerra! Para mim isso era muito complicado. Estava sempre em duas posições um contra o outro. Então, você ouvia as agentes falando da postura dos professores, os professores falando da postura das agentes e com isso um movimento dentro da escola (Maria, s.1).

Como briga: "Uma falava- eu concordo com a Silvia-e as outras falavam - Mas a gente não concorda-. Elas brigavam entre elas”. (Sílvia, s.1).

Como enfrentamento: "É muito interessante porque não houve um enfrentamento direto. Nunca houve discussão aquela coisa de uma tratar mal a outra. Jamais. Só que era um silêncio. Eu entrava, era um silêncio”. (Sílvia, s.1).

Como jogo de culpa: "Eu tenho visto situações ali muito complicadas. Daí, vem o discurso de culpar o aluno, de culpar a família e é aquele discurso vicioso que está na rede pública que vai rolando e acaba no aluno e na família como culpados e não tem jeito. É um desafio que a gente encontra"(Amanda, s.1).

Esse jogo é repleto de expectativas:

Eu acabei voltando para uma escola... Quer dizer, tinha um lugar, eu e a K., temos um lugar institucional um pouquinho diferente, apesar da gente trabalhar com o grupo que é ligado à supervisão e voltei também para uma escola onde eu tinha sido supervisora. Também passei por algumas coisas que são, assim, as expectativas que o grupo coloca em relação a você enquanto diretora, que a gente também coloca em relação ao grupo por já conhecer, de uma certa forma, aquele grupo.(Paula, s.1).

$$
\text { [...] }
$$

Clara - elas queriam uma coordenadora que chegasse lá, desse um planejamento pronto, que desse um registro pronto pra elas e como foi difícil construir junto, fazer junto e eu demorei pra fazer isso, demorei um tempo para perceber isso: o que elas querem de mim? (trecho, s.1).

No primeiro trecho, Paula, antes supervisora de escolas (na gestão da prefeita Marta Suplicy), se torna diretora de escola na gestão seguinte (do prefeito José Serra) e é "recebida" a partir desta sua história e ao mesmo tempo "recebe" seu novo grupo a partir do que já conhece dele de quando era supervisora do mesmo. Todas estas marcas políticas produzem a instituição "formação de educadores", delineiam os lugares, as relações são construídas neste 
cenário. No trecho seguinte vemos uma coordenadora querendo construir junto, marcando assim sua posição institucional do lado de uma gestão democrática, e educadoras querendo receber pronto, do lado da gestão centralizadora, o que faz a coordenadora indagar o que esperam dela. Amanda segue:

Amanda - A expectativa das pessoas quando eu cheguei, assim, existia toda uma fantasia em torno do grupo da coordenadoria. Quando nós saímos de lá e fomos para a escola o negócio foi meio complicado.

Mediadora - Como era essa fantasia?

Amanda - De que ia chegar impondo, falando, querendo mandar, querendo mudar tudo de uma vez e lá na minha escola, além dessa questão que acho que eu consegui ir mediando de uma forma ou de outra, alguns com resultado positivo, outros com resultado negativo. Eu tive um outro desafio ali logo de cara. Existia uma concepção de coordenação que me incomodava muito, que flagelava até, que é a coordenação de tarefeira que cobrava. É isso, vou cobrar isso tal dia, tal data.

Rita-Cobradora pedagógica.

Amanda - O coordenador que pensa sozinho, leva e vai ser assim. Tinha essa concepção na escola, além do que, a formação não ocorria ali. $O$ olhar do coletivo não era ocupado com a formação.

Mediadora - Era ocupado como?

Amanda - Para você ter uma ideia, existia um espaço de formação, pago pela prefeitura em que elas faziam artesanato na escola e elas ficavam tricotando. Eu até cheguei a pegar nesse ponto. A escola ainda tem um subterrâneo ali de relações que nunca aflora. Ali no tricô, o subterrâneo era meio que revolvido mas não saia daquilo, então , é uma formação de artesanato?!, pra que essa formação? Mas a CP não entrava na formação. Então, outras vezes o grupo lia um texto ou outro que a CP deixava, quando lia, os registros eram lamentáveis, e não que tenham melhorado do jeito que eu gostaria, mas estão melhores, quando tinha registro, aí, eu cheguei propondo outras coisas e estando com elas o tempo todo propondo objetivos, então, isso revolveu o subterrâneo e o grupo. Então, esse imaginário em relação à coordenadoria e eu chegando e ocupando o espaço de formação porque eu acreditava e acredito numa outra concepção de coordenação e eu fui trazendo para eles, fui discutindo com eles, então, foi complicado sim. (trecho, s.1)

Acima, as "pessoas" esperavam Amanda do lugar de "cobradora pedagógica", que ia impor mudanças que pensou sozinha. E ela queria mudanças, pois não acreditava nesse lugar para a coordenação, ela queria fazer a formação e mostrar sua concepção de trabalho, diferente do lugar atribuído a ela de "cobradora". Ao longo do trecho acima observamos muitos verbos, indicando ações que dão definição à função do coordenador pedagógico. Pelo direito: mediar, pensar, entrar (na formação), ler, registrar, propor (objetivos), trazer 
(discussão). Pelo avesso, isto é, a função negada: cobrar, impor, mandar, mudar (tudo), levar (pronto). Chama atenção o que foi para Amanda ser esperada desse lugar negado por ela: um flagelo.

Concordam entre elas que ocupar um lugar de formador na coordenadoria faz diferença, influencia os novos jogos relacionais, traz um "peso":

Outra coisa que contribuiu muito foi que elas não sabiam de onde eu vinha. Elas não sabiam nada da minha vida. Essa coisa de sair da coordenadoria e voltar para a escola, eu passei isso no Estado que, realmente, tem um peso enorme no dia-a-dia da gente, então, isso elas não tinham, elas não sabiam o meu histórico e eu falei muito pouco sobre isso. Então, foi uma relação, assim, mais tranquila. (Clara, s.1).

Não é a primeira vez que aparece no discurso delas uma referência a expectativas (autoritárias) das professoras em relação a elas, que vinham da Coordenadoria de Educação, cargo exercido na gestão da prefeita Marta. Ao mesmo tempo, quando falam dos conflitos vividos, marcam uma posição democrática para si, contrária ao "mando", identificado na posição do grupo formador da atual gestão do prefeito Serra. Reconhecem como produtor do conflito o desejo grande de mudar aquilo com que não concordam, a intervenção na formação, as críticas que fazem, junto com os julgamentos.

A partir deste ponto analisaremos a participação da mediadora na cena do "jogo" relacional. Vamos começar levantando os tipos de intervenção encontrados e suas produções.

Em muitos momentos a mediadora produz uma fala que é uma intervenção individual, com cada uma: "E hoje, como você pensa isso?”, "Como é que você chegou? Como foi a sua posição?”, "Que era qual? Como é que você define?”, “O que você acha?” (mediadora, s.1). São pedidos de esclarecimento individual, que produzem maiores detalhes sobre as posições assumidas e atribuídas, como podemos ver no seguinte trecho: "Junto? Se o grupo determina que não quer fazer nada, você..." (mediadora, s.1), "Mas eu não sei dizer a que esse grupo resiste. Eles querem fazer da maneira deles” (Rita, s.1).

Em outras, a mediadora segue o discurso produzido no grupo e propõe caminhos para as falas trazerem situações concretas, propõe temas e relações: “como foi essa situação concretamente?” (s.1). No trecho que segue como resposta à intervenção as práticas concretas 
do cotidiano puderam aparecer a partir da pergunta quebrando um ciclo de generalizações anteriores a ela. Depois: "Vocês estão falando de relações de força. Tem uma orientação e frente a essa orientação tem um grupo que segue e um grupo que não" (s.1). Neste exemplo a produção seguinte foi começarem a falar da prática de poder-resistência feita por elas "do lugar delas" e relacionar com o lugar do outro.

Destacamos um terceiro tipo de intervenção: "Então, começamos falando hoje do que aconteceu com aquele desânimo que algumas colocaram ter vivido no passado, desde 2005, e que algumas nomearam como depressão. Agora ao final dessa sessão, vocês terminam me contando...”. (s.1). Esta fala retoma o tema inicial e deixa em aberto o final da sessão, há um convite para que os relacionem.

As "entradas" da mediadora reorientaram, em alguns momentos, o caminhar da conversa. Seguindo as intervenções da mediadora nesta primeira sessão, podemos dizer que a mesma acabou focando mais os esclarecimentos e fez algumas reorientações que ajudaram a pensar no movimento grupal. Isto também contribuiu para uma sessão de "consensos"; para a reedição de posições relacionais vividas de desabafar, e a busca de apoio na cumplicidade anteriormente estabelecida com a mediadora e com as colegas de grupo.

Em alguns momentos, entretanto, se delineou uma tensão nova, de discordância ou de diferentes modos de ver uma situação, o que interrompe um pouco o consenso, a identidade discursiva entre a mediadora e o grupo. Vejamos o seguinte trecho:

Mediadora - Rita, agora pegando esse ponto que você falou, quando você estava começando a contar a situação, você falou que não queria nada delas e depois foi dizendo o que queria... como foi isso?

Rita - Isso foi no começo do ano que nós fechamos, o grupo falou o que queria quando a gente fechou o calendário, não foi assim imposto meu pra elas. (trecho, s.1)

$$
[\ldots]
$$

Rita - Foi no coletivo, porque tudo é discutido no coletivo (s.1).

No trecho acima vemos a mediadora apontando o que lhe pareceu uma incoerência no discurso de Rita. A negativa de Rita "não foi assim imposto", coloca a fala da mediadora no lugar de uma crítica e a fala dela responde à mesma, mostrando uma tensão. 
Houve alguma tensão também entre as participantes, quebrando o consenso por alguns breves momentos (pois o movimento seguinte, quando isso ocorreu, foi buscar a concordância) como ocorreu no seguinte trecho:

Letícia - Eu quero um caminho onde as pessoas possam trazer alguma coisa por mais que seja um absurdo que eu olhe e fale "mas que absurdo", mas que é uma experiência ótima de ver a pessoa fazer aquele absurdo.

Sílvia - O que você faz quando você vê um absurdo?

Letícia - Depende do absurdo. Uma professora que dá um desenho mimeografado, eu era intolerante a isso. Aí, eu fico pensando: além de um desenho mimeografado, o que essa professora tem que os alunos precisam? É claro que eu vou problematizar o desenho mimeografado.

Sílvia - Ah, bom!

Letícia - Problematizar num contexto onde ela tem outras coisas, o desenho eu falo....

Maria - Não vai fazer. Eu não permito...

Sílvia - Até a gente faz um monte de absurdos. É uma questão de dialogar com as diferenças (trecho, s.1).

Sílvia termina com um discurso teórico apresentando um pressuposto que as reúne: “devem dialogar com a diferença”. E a diferença de posição entre Sílvia e Letícia se apaga, voltam a se aproximar. $\mathrm{O}$ consenso evita o conflito, o confronto.

Mais à frente, na sessão, a mediadora faz uma intervenção que traz novos desconfortos e desdobramentos:

Mediadora - Nesse imaginário construído, vocês podiam me falar um pouquinho como vocês se viram contribuindo para isso?

Letícia - O que nós fizemos na Coordenadoria também...

Amanda - Hoje, com esse distanciamento, acho que não sei se foi construção, é claro que a gente tem uma parcela nessa construção, mas é complicado pensar. Acho que, na verdade, as pessoas que depois passaram a conviver com a gente desconstruíram essa impressão nossa de imposição. [...]

Leticia - Quando eu vim da coordenadoria, eu não fui com nenhuma imagem. As pessoas não sabiam que eu tinha passado pela coordenadoria e, aí, assim, acho que essa 
imagem também é construída por nós porque eu vejo tantas escolas no meu bairro porque a gente está tendo encontros nas escolas. Então, assim, eu não sei também e eu fico me perguntando, por isso que eu ando me questionando muito que o outro também tem alguma coisa para dar, não é só para a gente ter. Essa onipotência nossa me incomoda e as professoras da minha escola também são assim. É uma escola que tem essa onipotência e acha que a escola é melhor que as outras. [...]

\section{Paula - O que você tem a ver com isso?}

Letícia - Não tem a ver só comigo. Tem a ver com as pessoas que acham que fazem melhor, que é a melhor escola, que fazem melhor, é a melhor escola, nós somos reconhecidas. E isso impede que a gente veja também as dificuldades. Quando a gente fica muito tempo num lugar, a gente também começa a achar que é poderosa, que é maravilhosa e a gente acaba não criando ponte com outras escolas. [...] Eu tenho questionado muito isso porque eu sempre carreguei essa coisa que eu tinha que fazer, que eu tinha que dar conta e acontecia mesmo, porque quando você se dispõe a fazer você faz mesmo. Qualquer coisa que você se dispõe a fazer você faz. Então, para mim a questão está: onde está o desejo dessas pessoas, onde elas estão botando as energias delas? Porque energia têm. Eu fico nesse incômodo porque eu fico pensando: será que só meia dúzia de escolas são boas? Será que só o pessoal da Coordenadoria que faz? O pessoal do meu bairro fez um trabalho maravilhoso.

Sílvia - Esse ano a gente só conseguiu olhar para as nossas faltas. Eu falei: gente, vamos levantar o nosso astral, muito pelo contrário, porque a gente achou que a gente pecou num monte de coisa é que a gente podia ter feito melhor... mas teve coisa boa. Eu acho que pode ser onipotência, também acho que a gente tem esse sentimento, mas pelo menos eu assumo: eu acho que a escola pública está um caos. Eu não acho que todas as escolas são maravilhosas. Está uma porcaria, um caos, um horror. A gente está na área, a gente vê absurdos. Ai também é de doer, tem coisas que não dá.

Paula - Acho que a Le está falando um pouquinho diferente. Acho que cada um tem pique. Acho que o meu também foi diferente de todo mundo. [...] Acho que foi muito interessante essa passagem pra ser diretora mas foi uma passagem, simplesmente, naquele momento, muito curta porque foi no final de janeiro, quando eu voltei das férias, até agosto, quando eu fui chamada de novo para o concurso de supervisão efetivo. Aí, eu me vi numa posição diferente de supervisão, numa coordenadoria que eu já havia trabalhado anteriormente, antes da Coordenadoria ser desmembrada, num outro contexto, você falou da questão da política pública, aí está um outro contexto também de política pública.[...] $\mathrm{Na}$ supervisão, isso é interessante notar porque, assim, você trabalha conjuntamente com dois grupos: você trabalha com um grupo de escolas do qual você é supervisor, aí, você tem uma responsabilidade e você está num grupos de supervisores, num grupo de iguais, ditos iguais. [...] e logo quebrei a cara nesse grupo de iguais porque percebemos que não havia consenso. E como trabalhar num grupo que não tem consenso? O consenso que existe nesse grupo, por exemplo, é um consenso institucional das coisas que vêm instituídas.

\section{Mediadora - Então, como é esse consenso?}

Paula - É uma ordem. [...] Aí, assim, como é que você trabalha dentro de uma ordem institucional? Aí, você começa a trabalhar com as brechas, ou não. Algumas vezes, você mesma é engolida pelo momento, pelo movimento, pelo instituído. Outras vezes, você consegue trabalhar com algumas brechas. [...] E, quando você trabalha com as escolas, por ser até num outro momento, você vai tendo momentos em que você se coloca como supervisor que tem, quer queira quer não, um papel muitas vezes que é um papel institucionalizante e que é reforçado por algumas posições até mesmo da administração, de cobrança. Por exemplo, a questão da estatística nessa administração é muito forte. Então, você está sempre cobrando.(trecho, s.1). 
Neste longo trecho, o consenso é quebrado e reencontrado, as queixas são retomadas e algumas falas têm o tom de denúncia sobre si mesmas: o fato de terem imposto a formação nas escolas usando de um lugar onipotente, de quem se acha melhor que os outros (quando retornaram da Coordenadoria) fez com que recebessem a força de reação contrária, a resistência. Tais "denúncias" assumem ora uma forma mais forte e mais direta, ora uma forma mais branda como a que diz que a convivência foi melhorando isso, que o lugar de imposição pode ser desconstruído.

A luta da formação mostra a disputa por saberes, que tem como efeito fazer as pessoas se sentirem melhor do que as outras, afetando as práticas. A onipotência reaparece na fala de Letícia na qual se declara capaz de fazer qualquer coisa que se disponha a fazer. Sílvia segue trazendo o outro lado da curvatura da vara: seu grupo da escola saiu da onipotência e começou a olhar as faltas, mas ficou só nesse movimento e ela tentou levantar o ânimo dele. Oscilam entre os lugares de onipotência e impotência tentando dar conta da escola pública definida como "um caos, um horror". Paula, antes mais dura com a colega ("o que você tem a ver com isso?"), agora usa o diminutivo "Le” e explica a fala da colega para Sílvia. No final Paula identifica como um papel "institucionalizante" o seu de supervisora, reforçado pela administração Serra, de impor a cobrança "quer queira quer não". Há que cobrar resultados e isso é uma ordem institucional, resta para ela achar brechas e fazer mais coisas além das cobranças, para não ficar somente no que foi "instituída" a fazer.

O movimento iniciado após a intervenção da mediadora que procurou saber como elas contribuíram na construção do imaginário em torno delas foi o de identificar a parte delas no conflito (e assim atendem ao pedido da mediadora), e termina do seguinte modo:

Amanda - Mas voltando a isso que a Le falou, eu estou com isso na cabeça: a questão que entra na ordem do discurso... esse do imaginário em relação à Coordenadoria. Acho que a gente tem uma responsabilidade muito grande pela criação desse imaginário, sim.

Letícia - Até pela competência que temos também.

Amanda - Nós que voltamos para as escolas da Coordenadoria. A gente usou isso.

Leticia - A gente voltou mais poderosa da Coordenadoria.

Sílvia-Poder imensurável. 
Maria-Eram as "super poderosas".

Mediadora - Então, começamos falando hoje do que aconteceu com aquele desânimo que algumas colocaram ter vivido no passado, desde 2005, e que algumas nomearam como depressão. Agora a final dessa sessão, vocês terminam me contando...

Leticia - Do poder... Por isso que ao voltar para nossos cargos de origem...depois disso tudo foi muito difícil. Voltamos muito fragilizadas.

Sílvia - Chegar na escola com esse poder foi uma trombada. Da onipotência, de achar que tudo poderíamos fazer e transformar eu fui pra depressão.

Amanda - E ao movimento de resistência que fomos alvo também em função de todo esse imaginário que a gente construiu de poder, e a culpa de não conseguir. Achei que depois da coordenadoria conseguiríamos transformar a escola e não fomos capazes de mudar a realidade.(trecho, s.1).

Neste trecho final se veem na ordem do discurso, produzindo e produzidas nos lugares institucionais. Atendem mais uma vez a expectativa da mediadora e implicam-se na queixa. A experiência do Grupo 1 não foi capaz de ajudar a transformar a escola quando voltaram pra ela, e, ainda, influenciou a forma como chegaram e como foram recebidas nas escolas.

\section{2 - Segunda sessão do grupo}

A mediadora começa o encontro retomando o ponto de parada da sessão passada e com isso propõe a continuidade entre a sessão 1 e 2 . Amanda segue: "Eu dizia que somos coautores de um discurso que era uma armadura que vestimos para voltar para as escolas. Eu penso que nós também criamos resistências na nossa relação com as escolas". (Amanda, s.2). Amanda se declara coautora na produção da resistência na relação. O termo armadura remete a um aparato de defesa numa guerra: discurso-armadura que entra na nova relação resistindo. Nessa guerra, também atacam e são atacadas. Letícia continua:

Nós colocamos o outro no lugar do inadequado e aí nem tem nível de discussão, de tão longe que ele está. No meu caso, a diretora matava meus sonhos, ela dizia "Aqui não é Reggio ${ }^{33}$ ". E aí eu também matava os dela: não ia agir de acordo com o que ela queria. Que

\footnotetext{
33 Referência ao trabalho muito valorizado por elas e que é feito em escolas municipais de Reggio Emília, na Itália.
} 
imagem ela fazia de mim! E eu dela! Nesse ano, eu ia sair da escola, mas não consegui. Entrei na remoção, mas não consegui. Ela gostou de eu ter ficado e me disse: "eu não consigo entrar no seu pensamento". Eu também queria rebocar as pessoas para as minhas ideias, queria que elas pensassem como eu. A diretora me achava acelerada. E eu quando entrei nessa escola, me achava desacelerada. Entre os meus sonhos e a realidade da escola, nesse choque, perdi parte da minha energia. Eu acho que as professoras também. A reação delas foi de muita onipotência: "Nós somos ótimas, tudo o que a gente faz é bom", diziam. Quando eu pedia uma avaliação mais detalhada, vinham críticas, mas sempre ao outro. Sobre si estava sempre tudo bem. (s.2).

Ela apresenta uma relação de matar sonhos uns dos outros, de querer que o outro atenda à sua expectativa, de querer entrar no pensamento da outra para ela pensar igual. Esse igual aponta para pensar igual à educação, ou seja, faz referência mais uma vez à existência de posições de políticas educacionais divergentes cuja convivência se torna em alguns casos insuportável. Ser a favor de "Reggio" marca a identidade dela nesse grupo e na relação com a diretora, que se mostra desejosa de entrar no seu pensamento e mudá-la, pois gostou da coordenadora ter ficado e não conseguido a remoção. Letícia resiste "não ia agir de acordo com o que ela queria”, ou seja, o embate continuou. Quando ela como formadora não consegue "rebocar" as pessoas para as suas ideias, o lugar dado ao outro (as pessoas) é o do inadequado, e as relações que se estabelecem são de distância e impossibilidades. As imagens que umas fazem das outras parecem imobilizar as relações. Seu lugar era de meio entre a diretora que queria forjar o pensamento dela e as professoras onipotentes que negavam sua influência, por considerarem-se "ótimas", ou seja, não precisavam da formação que a coordenadora tinha para dar. Ela era vista como acelerada pela diretora e se via desacelerada, sem energia. Havia tensão em todas as direções e em todas as relações, isso a motivou a tentar a remoção: seria essa uma possibilidade de suspender a crítica e manter a sua energia? O que a remoção produz imaginariamente aparece como o que cessa o mal-estar. Abriria também a porta dos sonhos-mortos?

A remoção é um mecanismo institucional usado por elas em situações nas quais a convivência de uma pessoa no grupo fica insustentável. Mas é usado também em muitas outras situações, legitimando a rotatividade dos profissionais.

Neste trecho podemos perceber como o jogo de poder move a relação entre elas: há desafios, afirmações, negações, mudanças de posições e de vetores de forças nas relações. Aparece a dimensão produtiva da resistência em contraposição à dimensão de obstáculo presente de modo recorrente na sessão anterior. 
Vejamos como a sessão segue:

Clara - Não, não vou. Eu perdi a coordenação desse CEI. Chegou a nova coordenadora. Estamos todos de luto. O que elas incorporaram desse processo, fica. $O$ que elas tiverem feito pra me agradar se perde. A CP que vai pra lá é light.

Mediadora - Light?

Clara- Não vai bater de frente, vai escutar o que o grupo produziu, isso é bom, dá chance de algo ser continuado.

Mediadora - E você Clara?

Clara - "Eu sou professora de EMEF, vou voltar pra sala de aula, se não tiver nenhuma vaga pra coordenadora. Estou de luto de novo. Outra mudança, outra vez". (trecho, s.2).

Clara usa o termo "luto" para descrever uma posição institucional (como se sentem frente a tantas mudanças de profissionais possibilitadas pelos mecanismos institucionais da prefeitura). O termo acima, ao que tudo indica, foi usado para descrever uma posição subjetiva de elaboração de uma perda e de uma nova mudança. Como Letícia, Clara também faz referência à morte na situação de trabalho, referida agora como interrupção de um processo de trabalho e também como imobilização no sentido de estar à mercê de tal mecanismo. Clara parece admitir que parte do trabalho feito com ela se perderá, qual parte? A parte que seu grupo tiver produzido somente para agradar à Clara, a coordenadora. A parte do trabalho que o grupo de fato acreditou, produziu, pode ser continuada caso a nova coordenadora que entre seja mesmo "light". E ela, vai começar o processo, tudo de novo, mais uma vez, em outro lugar ou como coordenadora (formadora) ou em sua vaga de professora de EMEF. O mecanismo institucional permitiria esse tipo de engrenagem: pessoas entram e saem e se a frequência desse movimento é grande, o projeto da escola se sustenta com fragilidade, ou está sempre em mudança à mercê de quem chega, de quem fica, das batalhas que aí se travam entre mudança e permanência. Em sua fala, os procedimentos da burocracia "parecem ter autonomia" e elas se submetem (se sujeitam) às relações burocráticas e sofrem os efeitos da mesma: "luto".

Outro mecanismo que pode mobilizar mudanças ou permanências foi problematizado: o uso da avaliação institucional. Maria (s.2), diz: “As professoras passam o ano inteiro criticando, e na hora de avaliar, está tudo bem. Por que isso acontece? Porque se elas 
colocam a crítica no papel, a escola pode ser mal avaliada e isso pode significar que não venha dinheiro para a escola. É uma defesa, colocar crítica no papel, é se arriscar”. O momento da avaliação seria um caminho para críticas e mudanças, nem sempre desejado. Nesse jogo cada uma define seu lugar: "Na minha escola, toda hora que a gente tinha que assumir uma crítica e correr algum risco, eu ouvia da diretora: não quero arrumar para a minha cabeça. Vou dar a nota para tal professora. Isso é repetitivo”. (Clara, s.2). Clara aponta criticamente a decisão da sua diretora de dar a nota para evitar confusão. Já Rita coloca que: "Passamos o ano nervosas com uma funcionária e no final do ano na hora de dar a nota para ela, ficamos com pena. Se eu e a diretora não nos apoiamos, quase não avaliamos corretamente e teríamos que ficar com essa pessoa mais tempo ainda”. (Rita, s.2). Rita diz superar a pena que sentiu e, com o apoio mútuo entre ela e sua diretora, "correm o risco" e avaliam "corretamente" a funcionária com o intuito de afastá-la do trabalho.

A dupla coordenação-direção, quando não funciona de forma complementar, aponta para mais um conflito vivido cotidianamente. Poder trabalhar de forma complementar implica dividir pressupostos político-pedagógicos, o que na estrutura da prefeitura se mostra um exercício difícil permeado de relações complexas de poder e saber. No caso de Clara, a diretora define a posição da escola como a de "dar a nota" para a professora na hora da avaliação para "não arrumar pra minha cabeça". No caso de Rita, que vive a complementariedade com sua diretora e comunga com ela dos mesmos pressupostos, divide com a mesma o poder da decisão sobre a avaliação.

De uma ou de outra forma declara-se a supremacia dos procedimentos (burocráticos), no caso trazido por Clara, um sujeito que sacrifica a crítica em benefício da sujeição burocrática. No exemplo a seguir, detalham mais uma tensão:

As pessoas que mais resistiram foram as que mais avançaram. As outras ficam a margem, não se mexem, não se deixam tocar. Elas são refratarias, é um tipo de resistência não se envolver? Estou intrigada. Essas pessoas não fazem, não acontecem, não andam, não saem. Para algumas, falta caráter. Algumas não são honestas. (Letícia, s.2).

Na fala acima detalham a tensão de quem não se envolve. Percebemos, mais uma vez, o lugar positivo-produtivo da resistência, agora reconhecido por elas quando falam da tensão criada pelo polo de quem não se envolve no jogo da formação: as que resistiram mais, 
avançaram mais. A resistência nesta segunda sessão aparece como pertencente ao jogo, e até desejada (enquanto na sessão 1 era motivo de muita indignação ou conformismo): "Se não tiver resistência, seria estranho. É do humano. O que atrapalha é a paralisia: não poder pensar diferente”(Paula, s.2). “Eu resisto a esse novo que ta aí. A essa gestão”. (Maria, s.2).

Novos exemplos de atitudes das educadoras que recebem a formação são dados, alguns ainda muito extremados, como que para convencer o interlocutor a ficar ao lado delas, como vemos no trecho abaixo:

Letícia - Por exemplo, uma coisa é não dar espaço pra você entrar, outra é dizer que vai fazer e não fazer, e com isso, atrapalhar o grupo. Uma delas falta num evento importante que ela tinha responsabilidade e não avisa.

Mediadora - Como entendem esta escolha dela? O que vocês fazem com isso?

Letícia - Desonesta. Dou advertência. Encaminho para tratamento psicológico. Na maioria das vezes não dá em nada. (trecho s.2).

Letícia toma esta "falta" como algo que precisa de tratamento psicológico e/ou advertência, eliminando com tais práticas um dos polos de tensão. Interessante também que, na construção do cenário relacional institucional ela percebe o jogo e sua posição nele, e isso fica claro no começo da sessão com a fala: "nós colocamos o outro no lugar do inadequado e aí nem tem nível de discussão, de tão longe que ele está” (s.2). A "inadequação" atribuída ao outro como marca impede o investimento na discussão-relação. A única solução trazida no caso concreto apresentado é a saída da educadora inadequada. No início da sessão ela falava da relação com sua diretora, mas o mesmo mecanismo volta agora na relação com uma professora e ela não liga um exemplo com o outro. Neste ponto podemos entender como a instituição "formação de educadores" é construída em conjunto com todos os personagens envolvidos e na justaposição de lugares, atribuições e discursos. O encaminhamento para tratamento e a remoção são caminhos trilhados e legitimados para situações de grande tensão.

Com relação aos lugares ocupados pela mediadora, analisamos repetições em relação à sessão 1 quando oscila entre intervenções individuais querendo implicar cada uma em sua fala, como por exemplo: “Como é com você Cecília?”, “E você Clara?”, "Clara falou em repetição. O que fazem com ela? Como reagem?” e outras que começam a apontar o movimento do grupo: "vocês perceberam que a gente está falando de novo de casos em que 
não há nada pra fazer e voltando às queixas?” , e, “Quem é esse sujeito oculto? Quem institui tudo isso?"(mediadora, s.2).

O que aparece de novo na condução da mediadora é uma oposição, em alguns momentos ostensiva ao grupo, o que realiza um corte no consenso anterior. Antes estavam todas de um só lado, concordando com as críticas feitas ao outro lado, posicionado como o opositor: as educadoras apresentadas como "resistentes" e/ou, "inadequadas", as formadoras com suas contradições, a atual administração com suas imposições e burocracias.

A oposição entre mediadora e grupo aparece através de uma insistência: "Pra onde vamos com isso?" (intervenção repetida duas vezes), o que gerou na segunda vez uma irritação em Rita: “você fala isso de novo?”. Tais falas repetidas vêm em seguida a queixas. Elas fazem queixas e a mediadora faz a frase, elas repetem a posição queixosa e a mediadora, a intervenção, cria assim um "proibido": não é para fazer queixa, o que é confirmado nas falas de Amanda: "Fugimos da sua pergunta. Voltamos para a queixa" e, "Preocupante o poder desse discurso que a gente faz todo dia. Para que ele tá servindo? A gente quebra e reproduz o discurso, tudo recomeça. Quantas vezes a gente fez isso hoje...”. (s.2). Em outras situações aparece através do uso da ironia: "e esse grupo seleto daqui, cada uma, o que legitima?" (mediadora, s.2) e quando falaram que as funcionárias depreciam o ambiente de trabalho a mediadora diz: "só as funcionárias?". Estas intervenções puxaram um movimento de responsabilização como podemos ver no discurso que fazem em seguida: "Não, nós também. Nós depreciamos o nosso ambiente de trabalho e fazemos isso a cada dia”. (Clara, s.2). Ela responde a expectativa da mediadora como se fosse uma confissão, e a depreciação também passa para o lado dos proibidos e fica como um "erro" que foi apontado pela mediadora. Ao final da sessão, Rita diz:

Mediadora - Bom, gente, tá bom por hoje?

Rita - Tá né? Já entendemos! Chega né? (trecho, s.2).

A oposição gerou instabilidade na sessão e em alguns momentos parecia um jogo de "bate-rebate", cujo objetivo poderia ser entendido como o convencimento do outro e as 
jogadas e cortadas, como a argumentação-intervenção como nos seguintes trechos: "descaso de quem?”, "pra quê isso?” (mediadora, s.2). E ainda entre elas:

Letícia - Eu tive uma professora que não aceitava nada que eu dizia nem o que eu propunha e quando eu saí dessa escola, veio outra CP e questionou essa professora do por que ela fazia certas coisas e ela defendeu o projeto que ela tanto resistiu quando eu entrei. Ela mudou.

Cecília - Ela mudou ou resistiu às ideias da nova CP?(trecho, s.2).

Observamos também uma diferenciação no lugar das formadoras, nessa segunda sessão, principalmente no de Clara que parece ocupar um lugar que a separa do restante do grupo: esclarecer e quebrar a repetição do grupo, falar de como conseguiu quebrar repetições em seu grupo na escola, trazer as positividades do lugar da formadora. Sua tarefa, porém, não é um sucesso permanente, como se poderia esperar pela instabilidade que caracteriza as relações de poder. Em seguida às suas investidas, tentando levar o grupo para outro caminho, o mesmo retroage ao tema das queixas e, através dele, às repetições. Vejamos alguns trechos que mostram este movimento:

Por exemplo, quando as professoras fazem um planejamento e uma avaliação, só para entregar para a CP, só quando ela cobra e para agradar, é uma repetição. E a minha supervisora pede: "se você não fez o PPP $P^{34}$, entrega qualquer coisa". Não, eu não entrego, não tá pronto. Não vou fazer qualquer coisa. Vou fazer no ritmo do meu grupo, junto, mesmo que entregue fora do prazo. No final, a supervisora acabou me apoiando. Achou que eu estava certa. Com isso eu quebrei a repetição. E agora o projeto saiu e saiu no coletivo. Agora sim a gente se vê no projeto. Eu e as professoras. Acredito que agora elas também vão parar de repetir, repetir esse negócio de entregar qualquer coisa para agradar o outro. Acho que isso vai parar porque dessa vez elas fizeram junto. (Clara, s.2).

E mais uma vez: 
Clara - Eu falo das queixas para mostrar o antes, o que era gritante, e as mudanças que aconteceram hoje. Vou falar uma coisa boa. Nossa escola recebeu um prêmio do meio ambiente. Fizemos um projeto super legal.

$<$ Silêncio >

Cecília - Eu tenho me misturado à queixa do outro. Só falo com a minha diretora para reclamar do outro. Estou em crise, nem quero mais falar com ela. Recebo reclamações de todos os lados porque estou na coordenação. Recebo queixa e faço queixa. (trecho, s.2).

Se um tema muito repetido na primeira sessão foi o das oposições, na segunda foi a queixa e a negatividade imposta à cena da formação.

E demanda se esclarece também em torno da queixa como podemos ver nas palavras de Rita (s.2): “Ouvimos queixa toda hora. Recebemos queixa de todo lado. Nós precisamos agora de nosso espaço pra nos queixar", e "É tanta queixa que tem que pagar mais terapia. Preciso de ajuda do grupo". As relações ali constituídas com a mediadora na situação de pesquisa, de certa forma repetiram as relações que dizem viver nos ambientes de trabalho no qual fazem e recebem queixas.

Uma última intervenção foi tentada: "Vocês perceberam que a gente está falando de novo de casos em que não há nada pra fazer e voltando às queixas? Por quê?" (mediadora, s.2). Mas o efeito foi a produção de saberes sobre a queixa e assim fechamos a segunda sessão:

Cecília - Se eu devolvo a queixa que elas me trazem, elas boicotam o trabalho. Então eu escuto.

Letícia - A pessoa que se queixa não quer ela de volta. Se você devolve, ela não gosta.

Cecília - Às vezes, a solução para aquela queixa já veio, e ela nem viu. Do que ela reclamava então?

Letícia - Enquanto o outro reclama todos relaxam.

Cecília-Quem ouve alimenta o ciclo.

Clara - Quando pedimos pra construir a solução juntas é bom, ajuda, funciona.

Letícia - Quando não respondemos, o silêncio, o não resolver por ela também funciona. É ir contra a expectativa: que é resolver por. Bom, depois se queixam de mim. (trecho, s.2). 
E, com isso, percebemos neste segundo encontro repetições e rupturas. As recorrências apareceram, principalmente, no que diz respeito às posições assumidas pelas formadoras de trazerem queixas e de buscar os responsáveis pelos conflitos vividos, numa relação de exterioridade. Alguns movimentos diferentes foram ensaiados: buscar suas posições nos conflitos, identificar positividades na cena da formação, colocar-se ao lado das educadorasresistentes de quem tanto falaram na sessão 1. As rupturas apareceram com relação ao lugar da resistência e do resistente, que ocupou um lugar novo de produção de movimento e não de obstáculo e impedimento, possibilitando, em tais momentos, novas identificações: quem resiste se desafia, se relaciona, muda de lugar, avança.

Voltando-nos para as duas sessões, agora como um conjunto, percebemos que o grupo de pesquisa repete em ato a queixa e exerce a resistência recusada e apontada no discurso. A mediadora participa deste movimento como foi mostrado através da análise.

A análise institucional do discurso feita em seguida da primeira sessão ${ }^{35}$ contribuiu para mapear as posições e os caminhos trilhados, redirecionando o trabalho, no sentido de fazer uma interferência na condução de uma sessão para a outra. Isto fica claro na mudança do lugar do consenso, assumido pela mediadora na primeira sessão, para uma tentativa de diferenciação e distanciamento nessa segunda, o que contrariou as expectativas do grupo gerando mais instabilidade e alguma tensão ao tentar cortes para o grupo trilhar novos caminhos.

\section{3 - Terceira sessão do grupo}

A sessão começa com tentativas de relembrar o encontro passado e a mediadora puxa Cecília: continuar?

Mediadora - Você falou também alguma coisa nesse ponto não foi Cecília? Quer

\footnotetext{
35 Como explicitado no capítulo do método, a sessão foi discutida no grupo de orientação de Marlene Guirado.
} 
Cecília - E confesso que ainda tem um pouco isso da cultura da queixa, eu vou me queixar do outro que o outro já se queixou de mim e daí você vai nessa roda porque entrou na roda de se queixar. (trecho, s.3).

A mediadora pede a participação de Cecília, que atende seu chamado e expectativa e que vem em forma de confissão. A cultura da queixa começa a ser colocada num lugar "não desejado-proibido", algo que precisa de confissão. Depois de uma nova rodada em torno da queixa, a mediadora recoloca a sua demanda da pesquisa: "Se a gente for pensar no trabalho de vocês hoje, no cotidiano, que é pensar educação, fazer educação dentro da Prefeitura, como é que fica o fazer do formador do educador, as relações, a maneira como essas relações se constituem a partir do contexto de cada uma... o que vocês estão constatando, como se veem?" (Mediadora, s.3).

É Letícia quem puxa o grupo:

Letícia - No curso central que reúne todas coordenadoras de uma região, pra discutir e que é chamado de "rede em rede", quando eu estava nele eu fiquei com essa coisa da queixa na cabeça, que a gente falou no outro encontro, então, eu prestei muito atenção nisso e aí, elas começaram a queixar, elas, as nossas formadoras, queixando da administração, da avaliação, e, entregaram a avaliação para nós fazermos, falando mal do instrumento, o instrumento que iam aplicar em nós e nós, claro, já desdenhamos daquela a avaliação.

Mediadora- Avaliação que elas mesmas fizeram?

Letícia -Não, que veio de cima. Avaliação de xizinho, é tudo ou nada. A avaliação deles mesmo é assim: é tudo ou nada.

Mediadora - Elas são de onde?

Letícia - Elas são contratadas pelo pessoal da atual gestão.

Cecília - Engraçado é que a nossa formadora trabalha a informação, ela trabalha com o grupo e, mas a avaliação quem faz é a outra professora, a da administração. É uma coisa contraditória. (trecho, s.3).

Letícia responde à pergunta sobre a prática do formador falando do lugar de quem recebe a formação dos formadores contratados pela atual gestão; ela critica a gestão e as formadoras. Letícia e Cecília contam que ser formador hoje pra elas é receber uma formação que chamam de contraditória e explicam por que: a gestão da atual administração contrata formadores que fazem a formação (definida neste momento como trabalhar a informação, “com” o grupo, fazer e aplicar uma avaliação) e aplicam uma avaliação feita por outro 
profissional, pertencente à atual administração. Deixam claro que quem deveria fazer a avaliação é quem fez a formação e criticam a "avaliação que vem de cima e de xizinho, a tudo ou nada", neste sentido ficam do mesmo lado das formadoras: desdenhando do instrumento "autoritário" vindo da administração. Vejamos como continuam:

Mas eu não sei se elas também discutem lá. Mas é isso que me chamou atenção, me deu até dor de estomago na hora. Eu falei assim: gente do céu, eu não acredito que estou aqui nesse lugar oito horas e a mulher está dando um negócio para eu fazer, e ela está descendo o cacete no que ela deu para eu fazer. Por que fazer isso? Eu fiquei pensando assim: isso pelo menos a gente não fazia. [...] Quando nós estávamos na coordenadoria ... o nosso grupo antigo...a gente não queixava com nossos educandos, a gente não falava mal da administração, mal de nada, a gente levava a questão pra discussão. A gente procurava estar sempre numa situação de ser responsável por aquilo que a gente estava fazendo. E fazíamos o que acreditávamos, não mandadas. [...] Se tinha uma coisa muito imposta da administração a gente dizia: tem uma questão estrutural, a gente vê a contradição, o que a gente pode ver de brecha? $O$ que podemos fazer? Tentávamos pensar com o grupo como lidar com a imposição". (Letícia, s.3).

Letícia apresenta uma tensão em relação ao reconhecimento da sua filiação à ordem da Coordenadoria. Ela, como formadora de educadores do lado da "administração" na época, quando recebia algo "muito imposto", tentava pensar sobre como lidar com isso junto ao seu grupo. Impor algo é uma novidade que aparece do lado da sua filiação, antes era presente somente ao lado da filiação "oposta" e muito criticada como característica de um formador.

Uma questão já presente na sessão 2, e que retorna, é a produção possível a partir da posição de resistência, neste caso levando ao movimento de "procurar brechas", "pensar" e "lidar" com a imposição. Ação sobre ação: impor-tentar pensar, lidar.

No trecho acima, Letícia faz mais uma vez a divisão entre elas e os outros formadores: de um lado as formadoras atuais que se queixam, mas "aplicam" o instrumento avaliativo que criticam e de outro, Letícia e suas colegas de grupo, que "não fazem certas coisas" e frente à imposição da gestão educacional da prefeitura, reagem de um modo considerado por elas de "mais adequado". Elas acreditam na avaliação que fazem e quando obrigadas a levar imposições da "administração" (mesmo sendo do mesmo partido delas ou talvez até por isso), fazem diferente. Letícia e seu grupo posicionam-se do lado democrático (“pensar com o grupo", "levar a questão pra discussão"), do lado de quem faz o que acredita e por isso é responsável e colocam o formador atual delas do lado dos que obedecem mesmo não acreditando e, portanto, como "não responsável" pela aplicação do instrumento. A fala 
"fazíamos o que acreditávamos" abre ao mesmo tempo duas possibilidades: uma ação de apostar no mito da sua autonomia e outra de lidar com imposições sem perder a autonomia.

A próxima fala é da mediadora: "E o grupo antigo apareceu de novo!" (mediadora, s.3). Essa fala cria novo proibido: falar do Grupol. Neste trecho bem como na recolocação da demanda de pesquisa feita mais acima pela mediadora, podemos ver a preocupação da mesma em levar o grupo para um caminho novo, evitando as armadilhas de "funcionar como o Grupo 1". Letícia explica que usou o Grupo 1 para comparar e a mediadora não percebeu no momento, que falar do mesmo não significou necessariamente reproduzi-lo em ato ${ }^{36}$. Letícia segue com a crítica a respeito do instrumento utilizado pela formadora como avaliação, não se identificando com a preocupação anterior da mediadora. Vamos acompanhar como seguem:

Letícia - É o real da estrutura, você não sabe para o que aquilo vai servir, aonde vai chegar. Aí, eu olhei para todo mundo e todo mundo colocou o " $x$ " rapidinho para entregar.

Mediadora- E você, o que fez?

Letícia - Eu escrevi algumas coisas, também não me desgastei muito, tanto que confesso que me deu dor de estômago. Me deu uma coisa que eu não acredito: eu tenho que fazer isso. Então, a gente se vê obrigada a fazer muitas coisas também e as pessoas fazem com a maior naturalidade.

Maria - Só fazer o “ $x$ ” é muito bom.

$$
[\ldots]
$$

Letícia - Não, ela ficou lá conversando enquanto a gente fazia a sua avaliação. As duas formadoras ficaram conversando. Ela entregou a avaliação e ficou na dela.

Mediadora - Vamos ver se eu entendi... A formadora de vocês colocou a crítica, entregou o documento que não concordava, "com naturalidade como vocês disseram" e?

Letícia - Então, assim ... tem que fazer, tem que cumprir. Eu acho que essas questões de ter que fazer, ter que cumprir acabam desqualificando um pouco até quem vai ter que obedecer, nós gastamos um tempo que, sinceramente, eu não quero mais. Se você gasta um tempo desse, não é melhor fazer uma avaliação direito, então? A própria de " $x$ ”, vamos

36 A sessão três contou com um elemento de análise diferenciado, já que ocorreu após a contribuição do grupo de pesquisa da USP, para o qual a mediadora fez o relato da primeira sessão. Numa supervisão coletiva, a mediadora foi ajudada a olhar para as construções da primeira sessão de grupo e a pensar a terceira sessão (a segunda não foi analisada com a ajuda do grupo USP). Observamos neste trecho os efeitos da experiência de "supervisão" na construção da terceira sessão, constituindo mais um campo de expectativas que também produz os discursos: a pesquisadora-mediadora compreendeu que não poderia deixar o grupo de pesquisa seguir o rumo da primeira sessão (queixas, resistências e retornos ao Grupol) e que deveria deixar mais clara a sua demanda da pesquisa. As intervenções são os efeitos do reconhecimento-desconhecimento da mediadora sobre sua função, o que a análise posterior do discurso foi capaz de marcar. 
discutir essa avaliação, se é essa que tem que fazer, mas desqualificar, e nada propor... aí, todo mundo respondeu, fazendo de conta... que estava tudo bem... mas legitimando esse jeito de avaliar uma formação recebida.

Mediadora - E como será que as outras pessoas responderam? Legitimaram também?

Letícia - Alguns colocaram tudo ótimo, porque era isso mesmo, era tudo ou nada. Era "plenamente satisfatório" ou "insatisfatório". Não era esse o termo, mas era uma coisa assim. Não tinha um... Era uma coisa assim, alguns colocaram tudo e pelo menos umas seis pessoas do meu grupinho, aonde que as pessoas colocaram insatisfatório? No que diz respeito à administração e não à formadora porque a formadora se tornou uma pessoa do grupo e até que ela é amiga de muitas pessoas porque ela é da rede, agora está na formação e a formação foi boa, não foi uma coisa ruim. (trecho, s.3).

Letícia fala de um lugar de quem sabia que deveria responder diferente, mas acaba optando por não se desgastar, depois de viver o dilema: responder ao instrumento com o qual não concorda sem problematizar é entrar no faz de conta e naturalizar esse movimento do que é falso, além de legitimar o próprio instrumento como algo válido para avaliar uma formação. Letícia responde com a dor de estômago, ou seja, sentiu-se obrigada a fazer da forma prevista pela administração, mas o fez só em parte. A maioria entrou no jogo e respondeu quase tudo com o "plenamente satisfatório". Algumas pessoas do seu "grupo", ou seja, aquelas com as quais se identifica, colocaram "insatisfatórios" nos quesitos que avaliavam a administração. Nesta hora as formadoras atuais, antes criticadas, passam para o lado delas: "porque a formadora se tornou uma pessoa do grupo e até que ela é amiga de muitas pessoas porque ela é da rede, agora está na formação e a formação foi boa, não foi uma coisa ruim”. (Letícia, s.3). Todas (incluindo agora também as formadoras atuais delas) aparecem agora do mesmo lado, no lado do "insatisfatório" fica a administração (antes as formadoras atuais eram faladas com as que não fazem a avaliação "direito"). A administração passa a ser o inimigo em comum, externo, que reúne os grupos que estavam separados. As formadoras atuais aplicaram e criticaram a avaliação, ou seja, reagiram desta forma à imposição. De novo ação sobre ação: impor (poder) - criticar (resistência). Observamos mais uma vez a soberania dos procedimentos e a produção do sujeito burocrático. A subjetivação com a sujeição do corpo (dor de estômago) e o reacendimento da crítica em alguns momentos. Quem faz isso é o "real da estrutura" (algo fora delas e que as oprime): colocar formadoras, e quem recebe a formação a produzir avaliações que não se sabe ao certo a que vão servir, numa referência ao uso político dos resultados. Há a repetição deste ato que não avalia de fato, mas faz de conta, faz dele algo "natural", as pessoas não o problematizam, e, como diz Maria: "só fazer o x é muito bom”. Seguindo o curso da sessão elas trazem um exemplo prático: 
Paula - Essa questão da produção do resultado e da questão dos responsáveis por aquele resultado... Numa das avaliações que a gente fez que até Amanda falou da prova São Paulo...

Mediadora - Quem é esse a gente que você está falando?

Paula - A gente que eu estou falando é a Prefeitura. Foram feitas provas de avaliação de segundos anos, quartos, sextos e oitavos para as crianças. É uma avaliação institucional tipo Saeb $^{37}$ com características da rede Municipal e que os alunos são avaliados em cima de algumas expectativas de aprendizagem que foram "discutidas", porque elas foram apresentadas para que a rede colocasse algumas observações, mas isso foi muito complicado. Foi um processo muito rápido que não dá tempo das pessoas pensarem um pouco sobre isso. Foram feitos questionários para pais, paralelamente à prova. Então, foram mandados questionários para pais, coordenadores, professores, diretores, supervisores e a gente não tinha muito acesso, mas uma das escolas começou a mostrar o que tinha no questionário que era direcionado para os pais e esse questionário eles tentam pegar, puxar essa questão de quem é a culpa, por exemplo, dos fracassos da escola, então perguntam: os professores trabalham bem nessa escola? Aí, eles respondem: sempre, às vezes, poucas vezes. A pergunta é generalista e as opções de resposta são imprecisas. Outra: Você é informado sobre as faltas ou planejamento dos professores? Eu não lembro de todas, não sei se você lembra, Amanda. Algumas questões capciosas.

\section{Mediadora-Generalista?}

Letícia - Isso. Então, fica difícil de responder. Por exemplo, pra supervisão eles colocaram algumas questões assim: você acompanha a escola uma vez por ano, uma vez por semestre, mais de uma vez.

Mediadora - Isso foi uma questão para vocês supervisores?

Paula - E da mesma forma que foi para supervisores foi para o coordenador, para a diretora. Pra ver se bate...

Mediadora - Uma auto - avaliação, você recebe o papel e você mesmo preenche?

Paula - Isso. Só que as questões, são questões que direcionam. É difícil você, às vezes, como a Le falou, achar dentro daquelas alternativas a que você consideraria que melhor se encaixaria. Então, é uma produção que eu entendo, quer queira quer não, de responsabilidade em cima de um quadro, que se diz, de fracasso escolar. Então, vamos achar os responsáveis por isso, no que isso vai dar eu não sei.

Mediadora - e quando direcionam... produzem o resultado da hipótese inicial?

Paula - Isso mesmo! (trecho s.3.).

O Sistema de Avaliação da Educação Básica (Saeb), conforme estabelece a Portaria n. ${ }^{\circ}$ 931, de 21 de março de 2005, é composto por dois processos: a Avaliação Nacional da Educação Básica (Aneb) e a Avaliação Nacional do Rendimento Escolar (Anresc ou Prova Brasil). Tais provas avaliam as redes de ensino (gestão) e alunos. As avaliações do Saeb produzem informações a respeito da realidade educacional brasileira e, especificamente, por regiões, redes de ensino pública e privada nos estados e no Distrito Federal, por meio de exame bienal de proficiência, em Matemática e em Língua Portuguesa (leitura), aplicado em amostra de alunos de $4^{\mathrm{a}}$ e $8^{\mathrm{a}}$ séries do ensino fundamental e da $3^{\mathrm{a}}$ série do ensino médio, segundo site consultado em 14 de julho de 2010: http://www.inep.gov.br/basica/saeb/. 
O pressuposto rege grupo e mediadora: o tipo de avaliação de "xizinho" não é bom e deveria ser problematizado, a avaliação deste tipo produz o que quer medir. Chama a atenção a ambiguidade possível na frase de Paula: “numa avaliação que a gente fez" (s.3). Poderia indicar tanto quem fez no sentido de ter respondido a prova, como quem a produziu para ser respondida por outros. Em seguida vem a pergunta da mediadora: "Quem é esse a gente que você está falando?" (s.3). Paula responde de modo surpreendente: "A gente que eu estou falando é a Prefeitura”. (s.3). O sujeito da ação de avaliar que está sendo analisada pelo grupo é a prefeitura. Quem é a prefeitura? A "gente" ou "eles"? Outra ambiguidade aparece na resposta de Paula: ela define o "a gente" como a prefeitura, o que indica um pertencimento, mas no modo como continua observamos que quem fez a ação aparece indeterminado: foram feitas, foram discutidas, foram apresentadas, foram feitos questionários, foram mandados questionários. Na continuidade, Paula diz: "Então, foram mandados questionários para pais, coordenadores, professores, diretores, supervisores e a gente não tinha muito acesso” (s.3), o que a coloca de um lado e o sujeito que mandou o questionário de outro: não há um "a gente" da prefeitura. Fica no ar, em ambiguidade, o grupo de pertença e o grupo de oposição.

Paula nomeia esse tipo de pergunta da avaliação feita aos pais de "capciosa", e com o apoio de Letícia define o instrumento como algo que produz "culpados" pelo fracasso escolar dos alunos, pois é medido em cima de algumas expectativas, hipóteses elencadas a priori, para serem confirmadas. O instrumento é criticado também por fazer um controle dos discursos dos diferentes funcionários para ver se coincidem ou não, sendo mais uma imposição do que uma participação. É visto como um inquérito: "pra ver se bate".

Novos mecanismos institucionais se expõem na fala de Letícia:

Mas, vamos ver um caso... ao mesmo tempo que a avaliação faz isso tudo que falamos antes, tem um outra questão que é assim, nós levamos lá os nossos portfólios do que a gente fez na escola a partir da formação que recebemos delas e nenhuma intervenção nem leitura disso foi feita. Não seria um momento avaliativo ver as produções das crianças e o fazer do professor? Então, tem professor escrevendo "muito bem" no desenho da criança, o coordenador levando isso lá e ninguém sequer questionando. E o coordenador? O que ele faz com aquele "muito bem" no desenho da criança? "Lindo", "muito bem". Então, é engraçado que ao mesmo tempo que querem ver os culpados, fechar o cerco, está escancarado, cada um fica do mesmo jeito ... continua fazendo o que quer, porque ninguém viu os trabalhos que fazemos nas escolas, ninguém problematizou. Então avaliam com perguntas que procuram culpados, constatam algo, criam programas tipo o ler e escrever com cartilhas pra ver se o culpado - professor - faz agora direito sua tarefa e nada muda porque o miudinho de 
conversar sobre as práticas não é feito. E nada muda porque essa cartilha é mal recebida, se produz um monte de material, criam-se cursos de formação pros educadores usarem o material novo, e daqui a quatro anos, tudo novo, nova avaliação, nova formação e então, é aquela coisa mesmo, a pessoa que vem traz um monte de conteúdo, que até poderia ser bom, como em alguns casos é, mas não tem ninguém te ajudando a pensar neles. Não considero isso uma ação de formação. O que mudou no portfólio, o que melhorou? Aí, o que aconteceu? Tinha que escolher um trabalho para levar de um coordenador, como exemplo. E escolheram trabalhos de quem? Ela foi direcionando para escolher os trabalhos que ela também julgava que eram os melhores e não escolheram nenhum trabalho de CEI e nem o trabalho do bairro $X$. (s.3).

No trecho acima Letícia fala como quem flagra os movimentos institucionais e seus efeitos de circularidade: quem entra na gestão propõe uma formação aos educadores, diferente da anterior, ela é aplicada por certo período (quatro anos) e não produz as melhorias desejadas, desperdiçando o tempo dos profissionais e produzindo novos materiais que são mal recebidos e pouco utilizados. A concepção do que é formar mais uma vez se delineia e se positiva a partir da crítica feita, como: acompanhar as práticas (intervir, fazer leitura delas), ajudar a pensar nos conteúdos a serem ensinados, avaliar de fato e não no "faz de conta", analisando as produções das crianças, dos professores e dos coordenadores, problematizar, conversar sobre as ações.

Em seguida Paula e Amanda repetem uma fala de Letícia de "isso a gente não fazia lá na coordenadoria" e a mediadora acha a oportunidade pra voltar ao tema que a "perseguia nesta sessão - o fantasma do Grupo 1":

\section{Silvia - Claro. A gente fazia diferente.}

Mediadora - Vamos ver o movimento de vocês? Chama atenção vocês em diferentes momentos dizerem: a gente não faz assim. E aí, vai e contam como que está sendo feito hoje, e conseguimos conversar sobre as práticas atuais, mas aí vocês lembram aquele tempo passado de novo. O que é esse movimento? Tem um grupo que não morre?

Letícia - Não morre.

Mediadora - O grupo da coordenadoria está ainda aqui. Vê como que ela começa: a gente fazia assim...

Letícia - Mas temos mesmo um diferencial.

$$
[\ldots]
$$

Mediadora - Eu entendo que tem uma saudade, que tenha tido um trabalho bom e que tenha a saudade, mas eu estou tentando olhar para o movimento que esse grupo está fazendo aqui, esse grupo é outro, embora com várias pessoas que compunham o grupo antigo da coordenadoria, inclusive eu. Você não falou isso "que a gente volta retorna, volta e retorna"? 
Você tentou sair, você fez uma tentativa de sair e aí, o que você faz? Você pega o fantasma lá do outro grupo e volta com ele de novo. Como ele vai poder "morrer" assim?

Silvia - Mas a referência é essa. Qual outra referência que a gente tem?

Letícia - Mas quando não tinha esse grupo tinha a administração da Erundina, tem sempre um fantasma com a gente, de um grupo de trabalho que foi bom e que tentamos reaver.

Maria - Tinha sim.

Letícia - Você lembra quando nós começamos, a gente falava de quem? Administração da Erundina. Aliás, nós tivemos um mérito porque quem não viveu a administração da Erundina não entendia o nosso vigor. Agora, a gente fala da coordenadoria. É isso aí. Sei lá, também. Não sei.

Maria - Eu acho que tinha um diferencial mesmo. (risos)

Letícia - Isso eu já falei. saudosismo.

Maria - A gente olha para isso e não consegue, você vai comparar. Mas não é só

Silvia - A gente se sente abandonada e quando oferecem algo é imposição. (trecho, s.3).

Observamos uma batalha, uma tensão e uma divisão produzida no grupo: de um lado a mediadora faz uma pressão querendo "enterrar" o Grupo 1, tentando convencer o grupo atual a não mais falar dele e nem atuar como se estivessem nele (sendo que algumas concordam e ajudam a explicar esse ponto de vista, se colocando ao lado da mediadora). De outro, algumas defendendo a boa experiência com o Grupo 1 e tentando explicar que ele é uma referência. Nomeiam esse movimento de busca de referências frente ao "abandono" e a "imposição" que sentem na atual gestão. O grupo reage e estranha a posição da mediadora de "recusa" do Grupo 1. A mediadora nomeia esse movimento de "saudade", o que chama a atenção, pois esse termo não foi utilizado por nenhuma integrante do grupo, apontando mais para uma interpretação da mediadora (ou explicitação do seu sentimento?) do que para uma análise. Essa pontuação da mediadora que quer enterrar o Grupo 1, faz com que ele volte ao cenário principal, para ser lembrado e discutido, produz o efeito contrário ao desejado. E com isto a mediadora interrompeu o movimento de confrontar as referências entre grupos de formação vividos.

Os grupos das gestões Erundina e Marta que ofereciam a formação pra rede, se identificam no discurso pelo "vigor", pelo "diferencial", pelo "mérito", por terem sido referência pra elas, nesse sentido, produtivos e positivos. Elas querem "reaver" a experiência 
de ter um grupo de trabalho "bom", não necessariamente os mesmos grupos do passado. Há, porém, uma indicação dos lugares desejados: de quem faz e pensa a formação dos formadores e/ou educadores da rede de dentro de um partido político que pensa educação a partir da mesma concepção que a delas. Mesmo porque, nas sessões anteriores e também nesta, desfilam muitas cenas do mal-estar que vivem no dia a dia do trabalho, por pensarem a educação de forma diferente do grupo que está no poder atualmente. Cecília segue:

Agora, eu vivo numa outra posição, numa administração que não tem nada a ver com a anterior, com Coordenadoria, com nada, mas foi difícil de se construir isso. Mas eu penso: puxa, há possibilidades nessa outra também [...] Eu acho que apesar de muito fechado, massacrado, tem possibilidade, existe vida pensante nessa administração [...] você tem possibilidades ali. Eu consegui ver essa possibilidade com o sair um pouco dessa questão de desmistificar o E.P ${ }^{38}$ e a coordenadoria. Por que eu estava nessa situação? Porque para mim ou tinha que existir um grupo daquele jeito com as mesmas pessoas do bairro $Y$. e da coordenadoria ou não tinha possibilidade nenhuma. Mas eu tinha, em conjunto com esse grupo, que pensar em outras possibilidades. Pode não estar agradando a todos, mas está agradando. Então, eu fico pensando nas possibilidades que a gente tem aqui. (Cecília, s.3).

Essa terceira sessão também foi uma sessão de muitos consensos entre os membros do grupo, com alguns momentos de tentativa de diferenciação e oposição, como podemos ver no trecho acima. Neste trecho completo (reproduzido acima em parte), há nove vezes a palavra possibilidade. Esta palavra no texto mostra expectativa (de que algo possa acontecer) e não realização (algo que não ocorreu). Continuando a leitura percebemos que Cecília já está fazendo "algo" e achando caminhos, que prefere apresentar como possibilidade e assim não se diferencia de fato das demais. Cecília tenta inclusive "fechar" com o grupo quando critica a administração atual usando termos como "fechado, massacrado", mas ensaia suas diferenças ao desmistificar trabalhos anteriores e dizer que na administração atual tem vida pensante.

A colega Sílvia, porém, parece incomodar-se e segue uma conversa longa entre as duas. A colega relaciona essa "possibilidade" tantas vezes enfatizada a características pessoais de Cecília que tem uma concepção como a delas: "Eu acho que a gente tem possibilidades aí, mas tem uma coisa aí, Cecília, que é a sua formação... você dá conta dos grupos ... você tem uma concepção de educação”. (s.3). E continuam no trecho que segue com ajuda de Letícia: 

também.

Cecília - Tem outros grupos, outras pessoas, com outras características, mas boas

Letícia - Bom, então é um problema meu, é uma questão minha... não encontro interlocutores nessa administração. (s.3).

Quando Cecília declara sua diferença, observamos um movimento de apontar para problemas pessoais: "então é um problema meu, é uma questão minha” (Letícia, s.3). Tal movimento é uma característica repetida nesta sessão quando aparecem discordâncias: quando o outro-modelo para elas (que pode ser a colega do grupo ou a mediadora) recusa alguma fala ou não concorda com alguma fala, a tendência é recolher-se no individual, ou seja, apontar para questões, defeitos ou para boas qualidades individuais. Apresenta-se então, uma trégua no confronto, mas Cecília segue: "É difícil a gente se adaptar. Eu estou entrando... para o grupo de vocês há pouco tempo, às vezes, eu consigo me adaptar e, às vezes, não. Às vezes, eu penso que tenho outras coisas que eu posso estar pensando de outra forma, é difícil falar. Então, eu acho que é uma característica muito forte de vocês." (s.3). A reação de Letícia foi dizer que muitos outros vivem a situação de se fechar e ficar impenetrável e que entrar ou não depende de cada um também, com isso voltam à cena as responsabilidades individuais: “Aliás, no clube tem um grupo assim também. Ele faz uma força que ninguém penetra mais, ninguém entra mais, ninguém sai, fica uma coisa que eu nem sei. Lá no bairro $Y$, na prefeitura e o grupo de W. fez isso e o pessoal da Z. se sentiu isolada. Agora sei, por que eu entrei nesse grupo e os outros por que não entraram se eu entrei?” (Letícia, s.3). Apontar as responsabilidades individuais, neste caso, teve um caráter de "recuo tático" na tensão produzida pela medida de forças e de "capacidades". Elas continuam:

Que coisa! É! Mas eu estou tentando falar da formação dela, ela pessoa, Cecília. Eu acho que eu estou tentando, mas eu estou tentando falar que tinham pessoas ali que não eram mais do grupo, mas fazem parte de uma concepção. Agora tem outras duas pessoas lá que eu acho que fizeram mais diferença. Eu pelo menos compartilho um pouco mais da concepção da $B$, e ela é do $P S D B^{39}$, acho que a $B$ tem uma postura de formadora. Então, eu me senti um pouco mais contemplada, você tem que acreditar no seu formador porque ele tem alguma coisa para te dar porque senão você não fica ali. [...] Hoje é um governo do PSDB, é outra

39 PSDB (partido social democrata brasileiro) é o partido político do ex-prefeito José Serra que foi prefeito da cidade de São Paulo de janeiro de 2005 a março de 2006, quando foi eleito governador e deixou a prefeitura com seu vice, Gilberto Kassab, do partido DEM (Democratas, antigo PFL) que termina a gestão de Serra em dezembro de 2008 e é eleito prefeito novamente, estando no cargo até hoje. (Kassab foi secretário do planejamento na gestão de Celso Pitta de 1997 a 2000). 
administração, não é meu partido, mas eu acredito no trabalho de algumas pessoas, da B, por ex". (Silvia, s.3).

Sílvia busca formadores que possam ter algo pra lhe dar que ela deseje e isso está relacionado a compartilhar saberes de uma mesma concepção e não necessariamente a ser do mesmo partido político. Sílvia parece reconhecer as possibilidades de acordo e de transitar por outros grupos, o que é uma posição diferente dela na sessão. Ela continua: “Uma coisa que eu não consigo é quando eu não tenho empatia com o formador, porque eu acho que aquele formador não tem nada para oferecer. Isto acontece muito nos encontros que a gente é convocada!” (Sílvia, s.3). A convocação é mais um artifício usado muitas vezes para a formação continuada. Os educadores ou formadores, "tendo" que comparecer, reagem ao poder imposto de formas variadas, como diz Sílvia: “eu ficava ali, mas não estava ali”(s.3). Sílvia oscila entre aproveitar e não aproveitar a formação que recebe de pessoas de outros partidos. Ao final, como fica a relação com o trabalho que faz? Ela conclui: "Pensando em Educação eu não acredito, eu não acho que a gente vai conseguir transformar a administração, a política, a engrenagem toda”. (Sílvia, s.3). Sílvia diz que a educação não vai transformar a administração pública, mas pode achar modos de sobreviver à administração ("ficar, sem estar"). Vamos ver como continuam:

Letícia - Na administração do Maluf e do Pitta, nós montamos um grupo de pessoas que trabalharam no instituinte, era resistência mesmo. todos nós.

Silvia - Mas foi porque Maluf e Pitta eram... extremos em divergência em relação a

Maria - Não é essa coisa de convocação de hoje. "Você não quer ir? Tem que ir!"

Amanda - Eu queria não ir, eu queria dizer que não vou, hoje...

Silvia - Mas tem que ir para problematizar.

Letícia - Mas a gente não está problematizando mais nada, nós estamos indo lá por nada. Eu vou, saio com dor de estômago e não adianta problematizar. Agora, na administração do Pitta montou-se um grupo na instituinte. As pessoas da coordenadoria dele, que ele colocou lá, iam nos eventos que a gente promovia, mostra como eram boas e respeitadas as discussões.

Amanda - É verdade.

Paula - Eu lembro. (trecho, s.3). 
A possibilidade de sobrevivência frente à ruptura política que pode ocorrer a cada quatro anos aparece através da crítica (problematizar) e da formação de grupos de resistência (resistir é sobreviver). O exemplo que trazem é de uma situação vivida na gestão dos prefeitos Maluf e Pitta ${ }^{40}$, na qual criaram um grupo que promovia eventos e discussões críticas que eram respeitadas até pelas formadoras contratadas pela gestão dos respectivos prefeitos, como dizem no trecho acima.

Chama a atenção a fala "era resistência mesmo", como se o movimento contrário ao poder da atual administração que fazem hoje, não fosse resistência, como se distinguissem resistência política de resistência psicológica, sendo que para que a primeira aconteça é preciso haver uma gestão especialmente "divergente". Outro ponto: Maria diz que na administração de Maluf e Pitta tinham que ir às convocações, como se hoje pudessem não ir, ou seja, como se o "autoritarismo" declarado a respeito da gestão atual não fosse para elas, o "extremo de divergência”. Amanda já discorda, pois queria conseguir não ir às convocações de hoje. Participar para problematizar parece ter sido uma prática que funcionou nas gestões de Maluf e Pitta, mas que não tem funcionado em relação à administração atual: "não adianta problematizar”.

Nas conversas que seguem, este grupo começa a contar como faz para sobreviver a tantas mudanças políticas: "Nessa instituição, as políticas mudam muito, as diretrizes educacionais também. As pessoas mudam de função. De bairro. Procuramos quem nos ajude a trabalhar melhor" (Sílvia, s.3), "tem um grupo que não se larga, se procura” (Letícia, s.3), "É um grupo que te faz pensar, não te deixa morrer na burocracia” (Maria, s.3), "Quando estou no fundo do poço, ligo pra K., na conversa tenho mil ideias, vou lá e trabalho melhor ... ela me critica, me faz pensar" (Letícia, s.3), "se você quer saber, eu não sei se eu não tivesse esses grupos na minha vida se eu tinha sobrevivido" (Sílvia, s.3), "te faz crescer, ter ideias ... ganhar independência, se separar um pouco do movimento institucional, ganhar distância” (Amanda, s.3).

Os grupos e pessoas "referência" foram se constituindo em gestões anteriores a partir de características valorizadas como “o fazer, pensar, criticar, sugerir". Quem está de fora para entrar precisa comungar da concepção de formação atuada no grupo, e quem não compartilha

\footnotetext{
40 Ambos do partido PPB , partido progressista brasileiro. Partido que se manteve à frente da prefeitura, sucessivamente, de 1993 a 2000 (Maluf de 1993 a 1996, Pitta de 1997 a 2000).
} 
ou tem diferenças no modo de ver e pensar uma situação, ou não entra, ou tem dificuldade para se adaptar como declarou mais acima Cecília. Outro efeito identificado é o fechamento do grupo que se une para sobreviver; e mais uma vez é valorizada a produtividade, o que nos faz pensar também na improdutividade: "Não sei se é um hábito saudável a gente viver isso dentro de uma instituição como a nossa, se fechar, se fechar pros que pensam diferente, mas eu acho que também tem o lado saudável disso que é de transformar, querer fazer”. [...] “ “ São grupos de trabalho que produzem muito, desse jeito, mas que trabalham, que fazem as coisas acontecerem” (Sílvia, s.3). E: “tem outros grupos acontecendo dentro da rede. Quando eu fui lá naquela reunião central para discutir o documento de reorganização da escola, tem um grupo no bairro $Y$. que eles continuaram discutindo o documento, eles já se organizaram, entre eles, estão se colocando, lutando pra melhorar o documento dessa gestão, o grupo é bom”. (Maria, s.3). Identificam o movimento de formar grupos, como uma ação de organizar para lutar por algo ou contra algo, um formato que lembra o de uma organização política.

Outra prática aparece no meio da sessão também como possibilidade de sobreviver. Amanda diz: "Em outros momentos foram outros instituídos, porque eles mudam sim e acho que a capacidade que a gente tem para estar sobrevivendo a esses instituídos é via a essas brechas, é aquilo que a gente vai construindo, vai instituindo não como vindo da instituição, mas é aquilo que vem da gente, de baixo para cima, é isso que nos fortalece”. (s.3). E Paula continua dizendo que se a gestão atual vê como o mais importante falar e pensar na leitura e na escrita dos alunos e insiste nisto, a formadora pode trazer outros temas e pensar o currículo sem ser de forma tão fechada: "isso é uma brecha, quando você traz outras questões" (s.3). Letícia complementa: "nós concretizamos isso e estamos trabalhando com o conceito de espaço na sala da educação infantil e com projetos. É o que precisamos trabalhar na formação das professoras e não o que foi imposto... escutamos as professoras pra definir isso... as levamos pra ver como outras escolas organizavam os espaços ... isso fez sentido pra nós" (s.3). Maria traz mais um exemplo concreto falando do único momento em que conseguiu ter uma formação em cima do que precisava e que foi com uma amiga que deu um curso pensando na $\mathrm{CP}$ e no diretor pra discutir currículo: "são coisas que no instituído não está dado como possibilidade”. (s.3).

O termo "instituído" é definido como o que vem da hierarquia, de cima pra baixo, e a instituição, entendida como organização, fora delas e que recebem de cima pra baixo. Há intenção de transformar a organização da prefeitura e sua gestão, elas fazem isso construindo 
brechas que são os "instituintes", o que vem de baixo pra cima. No "baixo" elas se colocam pra dentro. A instituição aparece como algo fora delas e o instituído também, ambos mostrados como negativos. As brechas e o instituinte se posicionam como algo positivo e que depende da ação delas. Mais à frente, colocam algo bom como possível ao lado do "instituído": "Mas tem instituído que foi bom. Na administração do Maluf nós tivemos um curso na USP que eu amei, aliás, montagem de projetos e foi do instituído”. (Letícia, s.3).

Vamos acompanhar o próximo movimento do grupo no trecho abaixo:

Amanda - O nosso grupo tinha dez pessoas da cidade de São Paulo.

Silvia - Eu não consegui falar com as pessoas e quem eu encontro lá? $M, T, G$. as pessoas que eu tenho empatia, pessoas do nosso grupo. Aquelas que a gente vai encontrar em qualquer lugar que esteja sendo oferecido algo bom. (risos)

Mediadora - Mas foi oferecido leitura, escrita, dança e..., outras coisas na formação do pessoal dessa gestão?

Letícia - Várias. gostam.

Maria - Mas a própria escolha não é essa, muitas pessoas não escolhem pelo que

Letícia - Tem amigas da escola que elas gostam mais. A escolha não tem uma problematização, é pra ficar com as amigas. (trecho, s.3).

Voltam ao movimento de separar o que é boa formação e o que não é, onde a boa formação é oferecida, lá vão encontrar as pessoas com as quais se identificam: as que sabem diferenciar o que é bom do que não é. Agora separam do lado valorizado as formadoras que escolhem o curso "bom" e as demais, ficam do outro lado, mais desvalorizado, das que escolhem ficar com as amigas e não o curso.

A mediadora faz uma pontuação em seguida falando da divisão que fizeram entre as que estão onde tem coisas boas e o resto: "Vocês disseram antes algo que fez parecer que de um lado estão as pessoas deste grupo de vocês e que se encontram quando tem algo de bom e de outro, o resto”. (mediadora, s.3). Esta fala gera um novo movimento:

Eu acho que não é uma coisa tão fechada assim, Juliana. Eu acho que da coordenadoria para cá a gente está pensando muita coisa diferente também. Eu acho 
que tem que pensar que foi uma experiência muito boa a da coordenadoria, como foram outras, mas isso eu entendo que pelas conversas que a gente tem a gente não está se vendo tanto quanto antes, mas o grupo não pára, as pessoas não param e não estão cristalizadas naquele pensamento da coordenadoria. A gente está sempre procurando outras coisas, então, falar que a gente vai ficar cristalizado naquele momento da coordenadoria, então, agora chegou uma nova administração e a gente está se opondo, não é isso... (Letícia, s.3).

Em ato, mostra-se uma rachadura nas memórias do Grupo 1, bem como no lugar de importância dele, agora relativizado. A evocação da mediadora por Letícia sugere uma oposição, observamos uma quebra do pacto de concordância entre mediadora-grupo. Letícia não se reconhece como quem se opõe à nova administração, numa posição de "rebelde". A mediadora, na fala de Letícia, a veria nesse lugar, e, também, não teria acompanhado as mudanças do grupo e tomou o mesmo como "cristalizado" naquele momento da coordenadoria. E mais um exemplo: "Agora, sempre foi assim, antes da coordenadoria. Você falou que tem um fantasma Juliana, então tem um fantasma que é perpétuo. Não é a coordenadoria, foi a Erundina, foi nas outras gestões, esse grupo, eu várias vezes falei desse grupo para criticar o nosso grupo da coordenadoria, ele foi referência pra mim”. (s.3). Nesta terceira sessão fica claro que o fato de trazerem a coordenadoria e o Grupo 1 para a cena da pesquisa e de forma insistente e idealizada, se deu provavelmente por falarem com a mediadora, antiga formadora delas, ou seja, pelas expectativas reativadas, nesse sentido, desde o primeiro encontro. As intervenções da mediadora acabam por conseguir nesta sessão um descolamento da cena da coordenadoria do Grupol e outras experiências e outra relações puderam ser valorizadas e trazidas à cena da pesquisa, depois da última intervenção. Elas continuam:

Letícia - Não é mais o grupo da coordenadoria. O grupo da coordenadoria se constituiu sim, como um grupo de trabalho, estávamos no poder, fazendo a formação dos demais. Quando a gente vai em reunião e eu não conheço ninguém, começo a observar e sento do lado de uma pessoa que diz algo interessante. Você ouve a fala da pessoa, você ouve o posicionamento dela, se identifica, faz laço, entra pro grupo.

Paula - Mas acho que tem uma característica das pessoas que a gente está falando, independente de terem sido da coordenadoria, talvez seja uma ousadia no pensar.

$$
[\ldots]
$$

Paula - O que eu estou querendo dizer é assim: acredito nisso até o fim da minha vida. Eu acho que uma característica das pessoas desse grupo aqui de hoje e de outros grupos 
que a gente tem falado é dessa possibilidade da gente estar sempre pensando e repensando sobre o que a gente acredita, sobre o que a gente sonha por educação. (trecho, s.3).

Aparece mais uma vez a característica buscada e valorizada para fazer laço e montar grupos: ousadia no pensar, dizer coisas interessantes, pensar e repensar sobre o que sonha e acredita por educação. Fazer isto do lugar de poder é diferente de fazer isso do lugar que ocupam hoje. Resolvida a questão, a mediadora prossegue com uma observação:

Mediadora - Quando eu falei para vocês que a gente estaria se reunindo para pensar no que é educação e fazer educação na Prefeitura, do ponto de vista do lugar institucional que vocês ocupam e constroem hoje, porque esse é a proposta que eu fiz pra esses encontros, pra analisar na minha pesquisa, nós estarmos aqui junto, vocês hoje estão falando muito das dificuldades e resistências com relação a administração e a estrutura da formação proposta pela prefeitura. Hoje a cena da formação foi toda isso. Dá uma sensação de lonjura da criança, do professor.

Maria - Lonjura... acho que você me pegou.

Mediadora - Letícia, eu percebo pelas falas que vocês ocuparam o espaço de hoje, até agora, falando das lutas que vocês travam no dia a dia entre os formadores e que não ouvi as práticas que envolvem os professores e crianças das unidades de vocês.

Letícia - É... mas pensamos as práticas das nossas escolas. Pelo menos, com essas pessoas que considero formadoras... que são as pessoas com quem eu mais me identifico, eu consigo pensar a prática.

Cecília - É pensar é já fazer.

Amanda - Esse pensar que ajuda a gente a fazer. Quando a gente está pensando já está fazendo porque voltamos diferentes pras unidades.

Letícia - Eu quando quero pensar, eu quero pensar no que estou fazendo. Eu conversei com a $R$. no sábado e a gente falou do que a gente estava fazendo, como a gente pensava lá no projeto, como a gente está pensando no fazer, ela fala que está fazendo tal curso, então, vai ligando as coisas. Igual lá na dança a gente está fazendo lá o curso de dança e pensa como a gente está trabalhando com o projeto, como a gente idealizou e você ter a dança ali, como é que dança entra no projeto, que é uma coisa que não entrava. Então, para mim, está sempre ligada ao fazer. É isso que mais eu sinto falta, eu falo isso o tempo todo, porque eu não tenho com quem pensar o fazer, meu fazer que é formar os professores pra eles trabalharem melhor com os alunos. (trecho, s.3).

A mediadora faz uma observação que é um estranhamento. Elas continuam a falar do que recebem ou não de formação e não entram imediatamente no convite feito pela mediadora 
para falar do que elas oferecem de formação do lugar de cada uma hoje, que envolveria falar dos professores e alunos. Querem falar deles, "mas não tem com quem” e não aproveitam a fala da mediadora que se oferece para escutar. Falar da formação que oferecem é uma prática reservada aos amigos. Letícia continua: “mas eu queria ter espaço para discutir como é que eu entro no que é problemático da produção dela, falar disso com essa professora sem matála. Porque daí, eu entro matando, às vezes, esse que é o problema. Eu queria discutir com alguém como é que a gente pode entrar aí, isso é formação, aí eu vou entrando do meu jeito, sozinha”. (s.3). A relação com o professor é central na prática de formação e Letícia quer falar da condução desta relação básica (como entrar sem matar) e assim entra na proposta feita pela mediadora. Mais uma vez aparece a definição da cena da formação: é formar os professores pra eles trabalharem melhor com os alunos e nessa definição, a cena de serem formados na administração pública tão debatida neste encontro fica ausente.

Contam em seguida: "pra dar conta dessa gestão de controle de dados e planilhas, $e$ formações e convocações, já trabalho 8,5 horas por dia e pra fazer o que acredito ser a minha função, faço em casa, que é acompanhar a produção dos professores e crianças" (Letícia, s.3). Elas têm usado o tempo na escola para atender às demandas da atual administração, sobrando pouco tempo para fazerem o que gostam e acreditam ser a formação que devem oferecer e que esmiúçam no discurso: ler os cadernos dos planejamentos dos professores, acompanhar os projetos de sala, fazer devolutivas, estudar junto, conversar com professores, alunos e pais.

A queixa da formação atual recebida e dos outros que não são do "grupo delas" retorna: tem gente "encostada" na prefeitura, tem formador que não se interessa de fato pela produção do professor e da criança, o formador delas avaliou dizendo que estava tudo bom no projeto da escola dela pra não ter trabalho, brincam chamando o projeto do "rede em rede" de "grade em grade", ironizam a quantidade de papel produzida que parece uma "matula" - são as planilhas semanais. Letícia continua:

Eu desvalorizo a instituição, porque você desvaloriza quando vai buscar fora, nada muda. É. Eu desvalorizo aquilo que eu tenho e me sobrecarrego buscando algo que eu quero em outro lugar. Agora, eu já fui ouvida no Rede em Rede, mas quando levei a discussão foi também..... a discussão não atendeu a minha expectativa. É lógico que é minha expectativa, eu sei, eu tenho clareza disso. Tem hora que eu falo assim: é só minha expectativa, não é de ninguém mais. (s.3). 
As críticas são ditas, mas em seguidas negadas quando Letícia volta a dizer que deve ser problema pessoal dela: uma posição de culpabilização de si que faz a questão apontada perder a força. O vetor sai dos processos e conflitos institucionais para os intrapsíquicos. Cecília afirma: “mas não é só desvalorizar, o fato de buscar formação fora da rede. Tem muito dinheiro pra formação, temos direito de lutar para montar grupos que nos contemplem, de dizer o que precisamos e queremos. É desistir”. (s.3).

Interessante que depois disso mergulham no desconforto da posição originária delas de funcionárias públicas, como precisassem reescrever essa posição: “Eu, às vezes, me sinto à parte da prefeitura, é como seu eu não fosse da prefeitura” (Letícia, s.3). "Eu também, não me identifico com as pessoas da prefeitura, dos grupos que frequento" (Silvia, s.3), "É tão desvalorizado" (Cecília, s.3). De desvalorizadoras passam a desvalorizadas. E a sessão termina com o seguinte trecho:

Letícia - A imagem de funcionária pública na nossa área é muito ruim. Me incomoda esse negócio de ser funcionária pública, me faz mal. O meu marido quando eu falo da Prefeitura e tenho uma reunião ele me pergunta porque eu não posso faltar, eu digo que é dia de trabalho, tem reunião. Ele fala: Mas você tem dez abonos, pode faltar! Até eles entenderem que eu tenho dez abonos e uso se precisar..., eu me programo para dar o que eu necessito sem prejudicar o meu trabalho, custou, isso para o meu marido entender, é a fama da prefeitura. Então, essas coisas são um rótulo, eu não gosto de falar que eu sou funcionária pública. Todo lugar que eu vou de instituição pública eu não sou bem tratada, as pessoas te tratam como se você fosse uma imbecil. Eu fui agora fazer a validação do documento da minha filha e o moço perguntou porque eu não falei que era funcionária pública, mas eu nem pensei em falar que eu era funcionária pública, deixei ele achar que eu era só uma mãe.

Mediadora - E o que é bom? Que outros significados têm pra vocês?

Maria - É um precipício.

Mediadora- A Amanda está quieta.

Amanda - Eu estou tentando não me queixar, porque se eu falar vou me queixar.

(Risos). Se eu falar, eu vou me queixar;

Letícia - Então, nós vamos ficar todas recalcadas aqui se não pudermos nos queixar mais. (Risos).

Mediadora - Porque é isso, meu convite pra falarmos das práticas da escola... do que é bom não deu "adeptos"...

Letícia - Mas é isso mesmo. 


\section{$[\ldots]$}

Mediadora - É muito forte esse cotidiano para vocês, tá difícil né.

Letícia - É muito duro conviver com essa realidade.

Maria - E tomar cuidado para não ficar instituído mesmo, repetindo tudo que não gostamos... porque eu acho que esse é o medo... de ser engolido.

Mediadora - E todo cuidado, como a gente viu, quem faz o instituído...

Maria - Faz. Nós, né?

Mediadora- Vamos parar? Obrigada por hoje. (trecho, s.3).

A definição de funcionário público é a de um lugar profissional que oferece dificuldades para identificação, desvalorizado (lugar definido como um precipício), recebe uma imagem social e familiar ruim (pode abonar como quiser, não são responsáveis), são mal tratadas (como uma imbecil), vivem uma realidade dura (têm razões para queixar-se, sentem medo de serem engolidas no instituído). Na relação com a mediadora aparece neste final, como se fosse uma brincadeira, uma demanda de pelo menos ter o espaço da queixa (senão ficarão recalcadas).

\section{4 - Quarta e última sessão}

A mediadora abre o encontro numa posição diferente da ocupada anteriormente, anuncia que é o último encontro e pede que digam o que querem falar:

Mediadora - Bom hoje é nosso último encontro, do que vocês querem falar?

Amanda - Bom a gente já trabalhou muito com a ideia da brecha que estava tendo uma conotação para uma e outra conotação para outras. Aí, a gente acabou, não sei se foi bom senso, consenso, isso eu não lembro ou é uma coisa minha aqui, não tenho certeza, porque eu vou escrevendo não sei se é do grupo ou se é meu, ainda mais com essa coisa desorganizada que está aqui na minha agenda, que a brecha é um espaço para fazer diferente, um espaço para problematizar e abrir novas possibilidades para pensar, mais livre do que vem imposto pela administração, algo que a gente possa fazer da nossa função, em cima do que acreditamos. A gente trabalhou muito com o instituído e com o instituinte por conta de discutir o que é trabalhar numa instituição pública com mudanças de gestões, o que fazermos diante disso. Terminamos vendo que a instituição somos nós também que fazemos, 
por isso precisamos manter espaços de reflexão sobre o que fazemos, para onde queremos ir e o que estamos de fato produzindo. (trecho, s.4).

O movimento de Amanda é repetir o encaminhamento dado pela mediadora nos outros três encontros, ou seja, retomar um tema significativo da sessão passada. A fala dela também mostra uma concordância com um argumento que a mediadora teceu na sessão passada de que elas também fazem a instituição. O tema da brecha vem a partir de uma definiçãa: espaço de liberdade possível frente à imposição da administração. E também de uma constatação: trabalham numa instituição pública com mudanças de gestão, com as quais ora concordam, ora discordam. Elas continuam:

Maria - Brecha é mais ou menos isso que a gente falou, mas pensei no porque apostamos tantas fichas nela... se elas realmente são brechas no sentido de produzir um espaço mais livre de trabalho ou são caminhos que tecemos para aguentar e sobreviver quando estamos sob o comando de uma administração que pensa educação de um modo que discordamos.

Mediadora- Quando vocês falaram em brecha, eu fiquei pensando, quando você falou "não sei se é um consenso" não sei se é quase que um pacto das pessoas que estão aqui entenderem que dentro de um cotidiano difícil essa é a saída. Quer dizer, que dentro de um contexto, do cotidiano de prefeitura, essas coisas são colocadas dessa forma por vocês, que vêm esses pacotes que vocês estavam contando no outro encontro e que vocês não gostam, então a brecha seria "o caminho", o caminho natural desse grupo reagir frente as iniciativas dessa gestão da prefeitura.

\section{$[\ldots]$}

Rita - Fico pensando se a brecha é transformadora de algo. Não sei se muda, se algo é desconstruído, mas pelo menos faz você pensar de uma outra maneira. Acho que, talvez, o objetivo de agir na brecha seja resistir ao que foi pedido pra nós, seja até que mude o jogo. Não sei se a gente consegue chegar nessa mudança, mas pelo menos a gente tenta, reflete... enquanto isso vai sobrevivendo. (trecho, s.4).

A hipótese que a mediadora lançou da brecha entendida como o recurso desse grupo é incorporada por elas: um espaço de luta para tentar mudanças e um espaço de sobrevivência. Em seguida, Amanda tenta corresponder ao que a mediadora analisa na sessão anterior, que sentiu falta de que elas falassem mais dos professores e dos alunos e hoje ela traz essa proposta ao grupo, e com isto parece tentar atender a expectativa da mediadora. Vamos seguir esse movimento com o próximo trecho: 
Amanda - Aí a Juliana lançou uma pergunta também a gente falando muito em brecha, em pensar a brecha significando fazer, a Juliana lançou a pergunta: e o aluno onde está nessa fala, nesse discurso? Só ficamos falando das formações e das brigas. Daí fomos pra imagem do funcionário público e voltamos a falar do que vai mal. Eu gostaria hoje então de falar da minha prática que é formar professores e ajudar a fazer da sala de aula um lugar de aprendizagem.

Rita $-O K$.

Maria - A gente pode falar da formação que fazemos, eu não quero formar como fôrma, mas como forma, ou seja, quero que caibam as singularidades do educador, mas quando vejo práticas de professores que discordo, é difícil trabalhar sem acabar desejando "formatar", quero que ele melhore no que acho que vai mal, aí oriento, claro do meu jeito, puxando pra aquilo que eu acredito. Não é isso formação Juliana? A Letícia também falou isso no encontro passado, ela falou que não quer cair matando em cima do professor, mas quer que ele mude. Precisamos sim falar disso. (trecho, s.4).

Com a fala de Maria entramos na "seara" do trabalho de formação que carrega um desafio que tensiona o discurso: influenciar, formar, mudar o professor no que considera que vai mal, orientar, puxar o professor para o que o formador acredita, mas levar em conta a singularidade dele e não "cair matando". É uma tensão entre seus propósitos conscientes (elaborados nas reflexões) e a situação concreta de trabalho. Clara continua:

Clara - Pra mim é o espaço de cada um aí, de criação. Vai haver uma composição, vamos nos misturar, eu também vou ser influenciada, não é porque sou a coordenadora que só vou ensinar, vou aprender, vou também entrar nesse jogo, mas entrar aberto é o grande desafio. Acho que os problemas que vivemos ao sair da coordenadoria e voltar pras escolas, tô pensando agora hein gente, é que quisemos manter o mesmo modelo de formação, mas já era de um outro lugar, era pra ser outra coisa. Estamos tendo que reinventar, por isso fica confuso as vezes...

Amanda - É, não tinha pensado assim.

Clara - Olha, Juliana, Amanda, grupo, não sei se é isso, mas falar do meu cotidiano, eu tenho um exemplo de formação e criação, estou em estado de graça hoje porque nós fizemos a nossa Mostra Cultural, no CEI, no sábado, fizemos a nossa primeira Passeata do Verde e a nossa segunda Mostra Cultural. A Mostra Cultural acho que é um exemplo disso, do espaço de criação. O que eles faziam no CEI? Festa junina e festa da Primavera. E desde que eu entrei lá a gente tem discutido muito essa questão: por que esse tipo de Festa Junina, por que essa Festa da Primavera? O que a Primavera traz para a gente, traz para a criança e discutimos, discutimos e tentamos modificar essa festa, abrir para a comunidade, trazer a comunidade num outro contexto. Estou no caminho certo? Estou respondendo da prática, dos professores e alunos? Você queria isso pra sua pesquisa?

Mediadora-Continua... 
Clara - O que nós percebemos hoje é que não se fala mais em festa da Primavera lá. Quando a gente consegue montar a mostra, traz muito trabalho do grupo e de uma forma diferente. A mostra fala do trabalho dos professores, dos trabalhos que foram desenvolvidos com a criança, é a produção dos alunos, que não tem mais aquela coisa dos desenhos prontos pintados, mimeografados. Você começa a perceber a mudança de concepção do professor em relação às atividades, o que eles oferecem para a criança é melhor, a mudança na relação com a comunidade também cresceu, eles participam mais. Esse ano a nossa mostra, nossa, foi fantástica!!!

Mediadora - Eu não entendi qual o problema com a festa anterior?

Clara - Acontecia assim, Juliana, que eu questionava muito: monta-se a festa, chamase os pais para gastar o dinheirinho deles. Certo? Para arrecadar dinheiro para a escola. A festa junina acontece, geralmente, assim é também, a festa da Primavera, as maiores festas na escola são para arrecadar dinheiro pra escola e nós começamos a discutir isso. Por quê? Eu vivi uma experiência assim: eu no caixa vendendo fichinha, chegou uma mãe e perguntou: "você quer a pipoca ou o pirulito?" "Eu quero cachorro quente". "Não, cachorro quente o dinheiro não dá. Ou você come a pipoca ou você come o pirulito". "Mas eu quero cachorro quente" e, no fim das contas, ele ficou sem o cachorro quente. E aquilo me incomodou demais porque, Juliana, quando a gente fala na igualdade de condição, quando a gente fala que todos têm o mesmo direito e que a escola tem que trabalhar isso, a nossa prática é muito diferente. Então, quando você faz uma festa dessa, você privilegia quem? Quem pode pagar. Os que menos podem ou não vão à festa ou se contentam com o que tem de mais barato. A gente começou a repensar isso, contei aos professores o que eu tinha passado, deu uma boa discussão, cada um falou o que passou e vimos outros desconfortos com a festa, que eu não tinha visto, e aí a festa junina desse ano já foi completamente diferente, nós fizemos uma festa fechada de manhã, sem a comunidade, para as crianças se divertirem e comerem o que quiseram, era gratuito, e à tarde os pais vieram, participaram, dançaram quadrilha, $e$ partilharam do lanche, nós fomos discutindo tudo isso , falando o porquê da festa, eu questionei a festa ser pra ter dinheiro, quis saber o que como professores queriam ensinar com a festa. Então, essas coisas a gente conseguiu mudar no CEI, a festa vai ensinar muita coisa, uma parte é o que os professores querem, por exemplo, queriam a participação dos pais, eu queria uma festa pras crianças brincarem e comerem a vontade. Eu não sei se isso vem de encontro ao que vocês falaram a semana passada, mas tem algumas ações que a gente modificou muito lá e que acho que foi um avanço para a equipe, para mim principalmente, aprendi bastante. Acho que é um caminho. (trecho, s.4).

Clara inaugura sua fala numa posição diferente, ela traz uma situação de felicidade e nela analisa seu lugar de formadora, escolhe uma situação que deu certo, que ela considera boa e exemplar de qual é sua função formativa e seu lugar de coordenadora na escola. Ela se reinventa no discurso a partir da reorientação dada por Amanda e seguida também por Maria. Ela convoca todas a pensar de um outro lugar e tenta contribuir com a pesquisa; recoloca, assim, o grupo na cena da pesquisa e seu discurso é ocasião de se reconhecer nesse outro lugar chamado de "reinvenção". E deste lugar ela estranha certas práticas, leva como problematização ao seu grupo, argumenta, escuta, levanta os desconfortos dos professores, diz o que quer e negocia. Fazer esse movimento, e conseguir mudar aquilo de que não gostava lhe 
traz uma sensação de felicidade. São ações exercidas na formação que agem sobre a ação de outros e provocam movimentos.

O grupo interage:

Paula - A Clara não estava na última reunião. Quando a gente falou de brecha, a gente falou numa questão mais - estou falando até porque você não estava na última reunião - a gente falou mais da questão do instituído em termos de sistema e você está falando de uma brecha no sentido de quebrar com alguma cultura da unidade.

Mediadora - Instituído, instituição, parece que o sistema e a cultura da unidade são entidades externas a vocês Paula...essa visão do...

Paula - Juliana, sempre tem o que está instituído e é dominante na instituição. No caso da Clara era um outro instituído, de dentro da unidade dela. Era uma coisa que estava instituída na sua unidade e você trabalhou de.....

Clara - Eu entendo, mas não vejo assim dominante e dominado como você falou.... na formação há espaço de falar e escutar, influenciar e ser influenciado, tem coisas que vou brigar mais, ser mais enfática, outras vou impor pela minha posição de poder que me permite, mas no geral vou conversar. É um jogo relacional. Todos fazem, não sou eu a boazinha e elas as más ou vice-versa...

Maria-É, não é.

Clara - Aí, eu vejo isso na minha unidade, mas vejo dentro do sistema das escolas hoje. É um movimento da maioria das unidades. Em algumas há diretores super autoritários e coordenadores também, ou democráticos. Mas em todas têm esse jogo da formação, de jeitos diferentes, mas têm.

Maria - Eu estava pensando aqui a questão da repetição. Então, eu acho que o que torna algo instituído? Quando ninguém mais se pergunta porque, fica normal. A festa da primavera tava lá, era normal, precisou vir alguém de fora pra estranhar. Estou falando isso para chegar onde eu quero chegar. Por exemplo, lá na escola a gente já mudou mesmo. Quando a gente chegou, tinha só duas festas, todo mundo falava que o povo não ia e depois a gente conseguiu acabar mexendo nisso. Hoje, olhando para isso que eu estou vivendo agora, fazendo três feiras culturais lá na escola, fazendo três festas juninas, eu já acho que está se instituindo esse novo jeito. Tem que fazer alguma coisa para quebrar isso porque senão vai virar uma repetição muito igual e vai perdendo o sentido. A primeira foi muito interessante, a segunda também. Então, quer dizer, não que a deste ano não tenha sido, mas tem alguma coisa nela que vai se repetindo e, se a gente não faz alguma coisa e não mexe, não cria uma outra brecha, vai virando...instituída.

Mediadora - Mas agora é a ditadura da mudança?

Paula - Pensando agora o que é o instituído quando você falou, acho que é quando isso se torna uma verdade. Por exemplo, a verdade do grupo, aí, vem a verdade do outro também, é que ela precisava arrecadar dinheiro e que a festa era para aquilo porque as festas eram importantes por isso. A partir do momento que Clara questionou a verdade naquele momento, ela fez uma ruptura que foi, talvez, o que a Maria tenha feito na escola dela. Só que daí ela trouxe outras verdades. A verdade da feira cultural dela. Aí, já estou puxando para a Maria. A partir do momento que ela trouxe essa verdade, o pessoal começa a incorporar isso 
e ela mesmo está falando que já está incomodando porque daí já começa a tomar lugar de um outro instituído que é esse...da verdade absoluta...que não pode mudar...

Maria - Todo ano apresentando tais coisas, tais coisas. Aí, você já tem que quebrar.

Mediadora-Por que?

Paula - A gente acaba saindo de uma e entrando em outra. A gente também tinha uma verdade, tinha e temos, e queremos que o outro a reconheça, por isso argumentamos, mas isso até, de uma certa forma, uma hora ela se rompe. Não sei.

Rita - Eu não entendi o que você quis dizer.

Paula - A Maria não falou que o movimento que a Clara fez ela também fez um movimento parecido na escola dela. Quebrou com algumas, rompeu com algumas coisas que eram colocadas como verdades lá na escola. A partir do momento que ela quebrou, você acaba colocando algumas coisas no lugar e aquelas coisas que ela colocou no lugar acabam se tornando outras verdades que se você não toma cuidado, você... começam também a enveredar por outro lado. E aí que é o cuidado que a gente tem que ter...

Mediadora - Cuidado?

Maria - Cuidado com a instituição, pública ou privada, ou com a Educação. Por exemplo, Feira Cultural é uma coisa que acontece em todos os lugares. Ficou e isso é uma coisa que está aí. Então, acontece na escola pública, acontece na escola particular. Tem as modas de saber na educação....historicamente temos trocado de saberes...construtivismo com Piaget, depois sócio construtivismo com Vygotsky e assim vai... são as verdades de cada momento e que ficam como uma referência dominante... pergunte pra algum professor se ele não conhece isso.....será mal visto se não souber... todas escola tem que ter feira senão pega mal. Cuidar disso... então...pensar nas práticas e seus sentidos...

Paula - E aquele texto que lemos no ano passado: microrrupturas? Não sei se era bem isso... algumas microrrupturasque acontecem mesmo nos movimentos da escola...de que a ruptura não é total... Mas isso pode ser ...que as novas verdades acabam também se institucionalizando ...de uma outra forma. Não está falando que não é legal, mas o risco... (trecho, s.4).

No longo trecho acima encontramos Clara numa posição nova tentando apresentar como enxerga o jogo de poder nas relações de formação e o grupo vai mostrando algo que incomoda e que é um proibido entre elas: a repetição do mesmo, do igual ao do ano anterior, do saber da moda, de impor verdades. Apresentam também um objetivo: manter as microrrupturas, evitar que os saberes se tornem dominantes e que verdades se institucionalizem. Oscilam entre falar disso no concreto (Clara) e teoricamente (Paula). Elas se antagonizam nas cenas da reunião. Nas falas observamos o jogo do poder e da resistência em ato, no discurso delas, se fazendo, o que a mediadora chamou no momento de ditadura da mudança: ter que ser contra, ter que fazer diferente. A teoria aparece como forma de resistência, o texto "do ano passado" dita o que deve ser feito. 
Elas deixam entrelinhas, é uma fala cheia de reticências, falam e não completam tudo que começam, consideram que o interlocutor sabe completar, ou seja, que ele conhece os pressupostos, a conversa na qual não se precisa dizer tudo para o outro entender mostra um gênero discursivo comum: microrrupturas, construtivismo, instituído, dominante.

Clara segue:

Clara - O que eu acho legal é que nesse movimento do grupo é que você chega no grupo e o grupo está ali, como que eu posso dizer, como se fosse uma coisa acomodada, as vezes parada, amarrada, você se aproxima, descobre como eles estão pensando e propõe outro jeito... se algo muda é uma ruptura...até quando? Não sei... ? Eles pensam assim e vão defender esse novo jeito quando eu sair? Espero que sim, que tenham mudado e não mudado pra me agradar.

Mediadora - Você já falou isso antes, como era mesmo?

Clara - É..me preocupa...O grupo da unidade toda. Juliana, é difícil alguém que esteja fazendo uma coisa muito diferente, como elas falaram da feira, do modismo que vira referência a seguir. Mas, aí, quando você mexe numa pecinha desestrutura tudo. E eu mexi no meu lugar e aí mexeu no delas... Por exemplo, essa coisa da festa junina, mexeu também na relação com os pais... Só que eu acho que é uma forma de você cutucar para que as pessoas consigam ter uma visão diferente e começar a avançar no trabalho. Então, acho que você trabalhar no dia-a-dia, naquela coisa pequena que é "trabalhar" o grupo, acho que mexe com essas questões todas. (trecho, s.4).

Clara relaciona essa ação de romper com o comodismo do grupo, de desestruturar as práticas como uma ação pertinente da função formadora e que ela gosta, nomeia essa ação como "trabalhar grupo". Ela também conta como faz isso: mexendo na sua posição, assim mexe com a posição das demais. Fazer este tipo de formação não provoca a mesma reação relatada pelas demais. Aquilo com que ela se preocupa é que as mudanças sejam feitas de fato por mudanças na posição das pessoas, e não para lhe agradar.

O grupo pega um caminho longo a seguir que chamo da trilha da teorização, vejamos: "a escola de um modo geral, a Educação, ela tem lá algumas verdades que já estão instituídas que quando você tenta quebrar isso, todo mundo se assusta, tem medo" (Maria, s.3), "Isso é uma coisa da escola? Não dá para a gente pensar a escola desapegada da sociedade" (Paula, s.3), "Até dialoga no sentido que ela está cumprindo o papel de reprodução” (Amanda, s.3). E: 
Amanda - Mas a ideia é essa, ela foi criada como instituição, ela cumpre direitinho. Ela ainda normatiza, ela ainda vigia e pune. Ela faz tudo isso direitinho, bonitinho, a pública e a privada de maneira geral. Então, ela dialoga desse jeito: ela cumpre o papel para o qual ela foi criada. Aí, quando a gente fala de brecha, é tentar escapar disso e a gente não consegue o tempo todo. Consegue algumas escapadelas.

$$
[\ldots]
$$

Paula - Mas é um dos papéis. Nem sei dizer se o central, mas é papel da escola reproduzir o status quo. A relação com o conhecimento está propagada como o objetivo maior, mas eu vou muito mais pela linha do que a Amanda falou.

$$
[\ldots]
$$

Maria - A própria Educação, a própria escola. Ela acredita que está nesse processo democrático e tudo mais. Ela acredita nisso quer dizer que as pessoas que estão lá acreditam nisso.

Amanda-Acho que muita gente já está desacreditando.

Maria - Mas as pessoas da administração quando soltam seus projetos educacionais acreditam no que estão fazendo o que está no papel.

Amanda - Isso é ideológico.

Maria - E quando você questiona isso a escola se perde. É o que está acontecendo, perdeu, não sabe pra onde ir. (trecho, s.4).

Discorrem sobre mais temas como resistência, sociedade, educação, instituição, poder público, repetição, onipotência, ideologia e etc. Com isso há um rebatimento fácil da iniciativa de trazer à cena o movimento de arriscar posições e inventar novos lugares para as formadoras, de trazer as tentativas que chacoalham com a inércia da crítica teórica, e assim, o grupo se mantém nessa conversa, variando o responsável pelos problemas (a sociedade, a escola, o professor - termos genéricos) e os problemas (escola que reproduz, controla e vigia, exclui quem não se adequar, se sobrecarrega de ações da saúde, fica com o papel central de resolver a exclusão social). Há uma distância entre quem fala e o que ele fala. A mediadora tenta marcar "quem faz" toda vez que falam: "a escola, ela faz, ela acredita", mas isso não breca o movimento do grupo de tratar "a escola" como um ente com vontade e intenção própria. Em alguns momentos trazem os atores (as pessoas, muita gente, e depois, as pessoas da administração) que fazem a escola e são "as pessoas", as responsabilizadas pela situação da escola. 
É Cecília que rompe com a complementariedade e traz uma discordância que demora a ser escutada. O estranhamento da posição da "colega" dentro deste grupo é uma situação rara, na maior parte do tempo concordam e se complementam:

Cecília - Estou achando interessante que vocês estão colocando que o aluno rasga e joga fora o caderno no final do ano e isso agride o professor que trabalhou o ano inteiro com aquele caderno, com aquele material. Mas não significa que o conteúdo não foi aprendido pelo aluno.

Amanda - Estou falando do significado dessa atitude. Eu, por exemplo, tenho agenda desde 1980.

Cecília - Eu não gosto de guardar.

Amanda - Não sei se é questão de gosto de guardar. Você até joga um caderno em outro contexto. Agora, pegar e rasgar na porta da escola é um péssimo sinal.

Mediadora - O que você está propondo, Cecília?

Cecília - De repente, você joga fora em casa. Joga fora esse caderno velho, mas você não joga na porta da escola na cara do professor. Eu estou vendo com uma ofensa, eu ia falar: pôxa, meu trabalho está todo ali mas, de repente, pensando de outro lado: está acabando, estamos e férias, você também quer férias. Então, ôba, acabou mas eu aprendi, eu trabalhei, o conhecimento está adquirido, não preciso mais do caderno.

Maria - É ...é ...tem um padrão, é uma verdade que a gente está estabelecendo: você tem que guardar o caderno. É só guardando que você está aprendendo. Ta vendo como é esse movimento em educação? Será que tem jeito certo, verdadeiro? Tem que guardar? Acho que é isso que a Cecília trouxe. Será que tem que guardar caderno? (s.4).

E, numa provável tentativa de acordo, também como movimento de última reunião de grupo, as participantes deste grupo parecem dispostas a aceitar e incorporar o ponto de vista divergente, acomodando-o entre os demais. As provocações para pensar diferente do que estão pensando são aceitas; elas mesmas colocam como ação importante do formador o fazer pensar, o desestruturar.

A proposta que vem em seguida é pensar sobre o que colocam no lugar de certo e errado: "Essa coisa do certo e do errado? Acho que essa coisa do certo e errado é muito forte dentro da escola”. (Cecília, s.4). As conversas seguintes mostram que elas estão num lugar de questionadoras das verdades veiculadas, trazem exemplos disso e a conversa envolve a todas, elas se complementam e concordam com a temática que escolheram para problematizar que é padrão considerado ideal. Vejamos um trecho: 
Cecília - Ela estava falando e eu estava pensando. A queixa que chega ainda, de alunos que têm suspeita, que necessitam de atendimento psicológico, ainda é a família desestruturada é no sentido do pai e a mãe serem separados. Ainda é a separação, a pouca presença da mãe que foi trabalhar fora, o.. não ter o pai presente. Ninguém olha para essa família e vê que a mãe tem que trabalhar para sustentar a família.

Maria - A gente tem alunos que vivem com a avó e estão super bem criados.

Cecília - Mas ele precisa de atendimento psicológico porque ele não tem pai e mãe juntos e do jeito padrão... é nossa função como formadoras pensar nisso, não encaminhar todo mundo pra atendimento. Eu recebo encaminhamentos das escolas e problematizo com as famílias e volto com quem encaminhou pra conversar, pra dizer o que penso disso.

Maria - Em compensação tem outros que têm pai e mãe e é um tormento na família e na escola. É essa coisa que eu estou falando da moral dentro da escola que é muito rígida. Tem esse padrão.

Paula - A gente não consegue desvencilhar de tudo. (trecho, s.4).

Questionar os padrões "ideais" que são criados nas práticas educativas é apresentado como uma função da formação, mas que não é possível ser feita por completo. E Clara continua com o tema da formação:

Clara - Na creche, não tinha nada de projeto, estavam começando a entrar na Educação, não conheciam nada da Educação, o diretor não era Pedagogo. Então, ele não tinha essas exigências da Educação: projetos, planejamento, olhar pras habilidades das crianças, apostar na inteligência. Era só cuidar da criança, pôr no sol. A rotina deles era completamente diferente.

Mediadora - Olha que interessante, ela está dizendo que não reconheciam essas questões da Educação. Quando você entra, você traz as práticas educativas? s.4).

Clara - É não tinha essas cobranças da educação... eu levei na formação. (trecho,

Clara conta no trecho acima mais uma cena do que é fazer formação do seu lugar de coordenadora de creche: levar conteúdos da educação e práticas educativas. Amanda complementa com a sua diferença: tem vivido muitas dificuldades em ser aceita com o que quer oferecer como formação na escola de ensino fundamental, e, mesmo assim, tem conseguido trabalhar com alguns grupos. Seu trabalho é definido como tentar se aproximar 
das práticas das professoras, ajudar no que precisam com os alunos, entrar em sala, fazer junto, para depois problematizar o que acha que poderia melhorar.

Em seguida, a mediadora encerra a sessão abrindo para as falas finais e deixando os temas livres:

Mediadora - Bom, vamos ter que encerrar agora. Alguém quer colocar mais alguma coisa considerando que é nosso último encontro? Como foi?

Amanda - A prática do formador é cheia de dilemas, dificuldades e antes só nos queixamos, hoje também, mas falamos também do que conseguimos, não resolvemos os dilemas e os problemas, mas falamos de como tentamos trabalhar apesar e com eles. Gostei mais. Eu saio tendo maior clareza do meu lugar atual, gostei da fala de Clara: se reinventar. Sem negar ou enterrar o que acredito, mas levando comigo pra negociação, mas aberta, né Clara?

Rita - Difícil se manter pensante nesse jogo de tantas influencias mútuas do formador. Vi como vamos seguindo o fluxo e é preciso às vezes dar uma parada.

Paula - Na supervisão tá difícil, percebi como estamos de mãos dadas com a burocracia e muito longe das escolas, mas foi bom ouvir vocês, o que estão fazendo.

Clara - Acho que as metas do ler e escrever prometidas pela gestão atual, deixam eles não tão em cima das creches. Pra mim tem sido mais fácil sem a pressão da atual administração.

Cecília - Pena a Sílvia e a Letícia não estarem hoje...eu gostei dos encontros, gosto deste grupo corajoso que topa tudo, que quer lutar pela melhoria do sistema público de educação, até pra não termos vergonha do nosso espaço profissional...e do nosso salário!

Maria - É, podíamos continuar... tem tanto conflito em nosso dia a dia que é bom tentar ganhar uma distancia e se ver nele...eu volto pra escola amanhã menos presa no ter que mudar tudo sempre, se a festa tá boa, deixa ela! Influenciar o outro, faz parte né, o negócio é garantir a possibilidade de existência do outro, mas lutas...vão ter né!

Mediadora - Bom, muito obrigada pela presença e colaboração de vocês.

Paula - Você vai fazer uma devolutiva depois que trabalhar nos dados? Quem sabe nos ajude a sair desse labirinto...

Mediadora - Vou sim...vou tentar...eu ligo pra vocês ...(trecho, s.4).

A pesquisa aparece citada agora nesse final, junto com uma expectativa: apostam que a análise da mediadora vá ajudar a que saiam "desse labirinto". Apontam ao final as contribuições deste exercício: distanciar, ter mais clareza do seu lugar e olhar os jogos (lutas por influenciar) presentes na formação, achar as positividades, ouvir a outra, ficar menos presa a "ter que ser assim ou ter que mudar". 


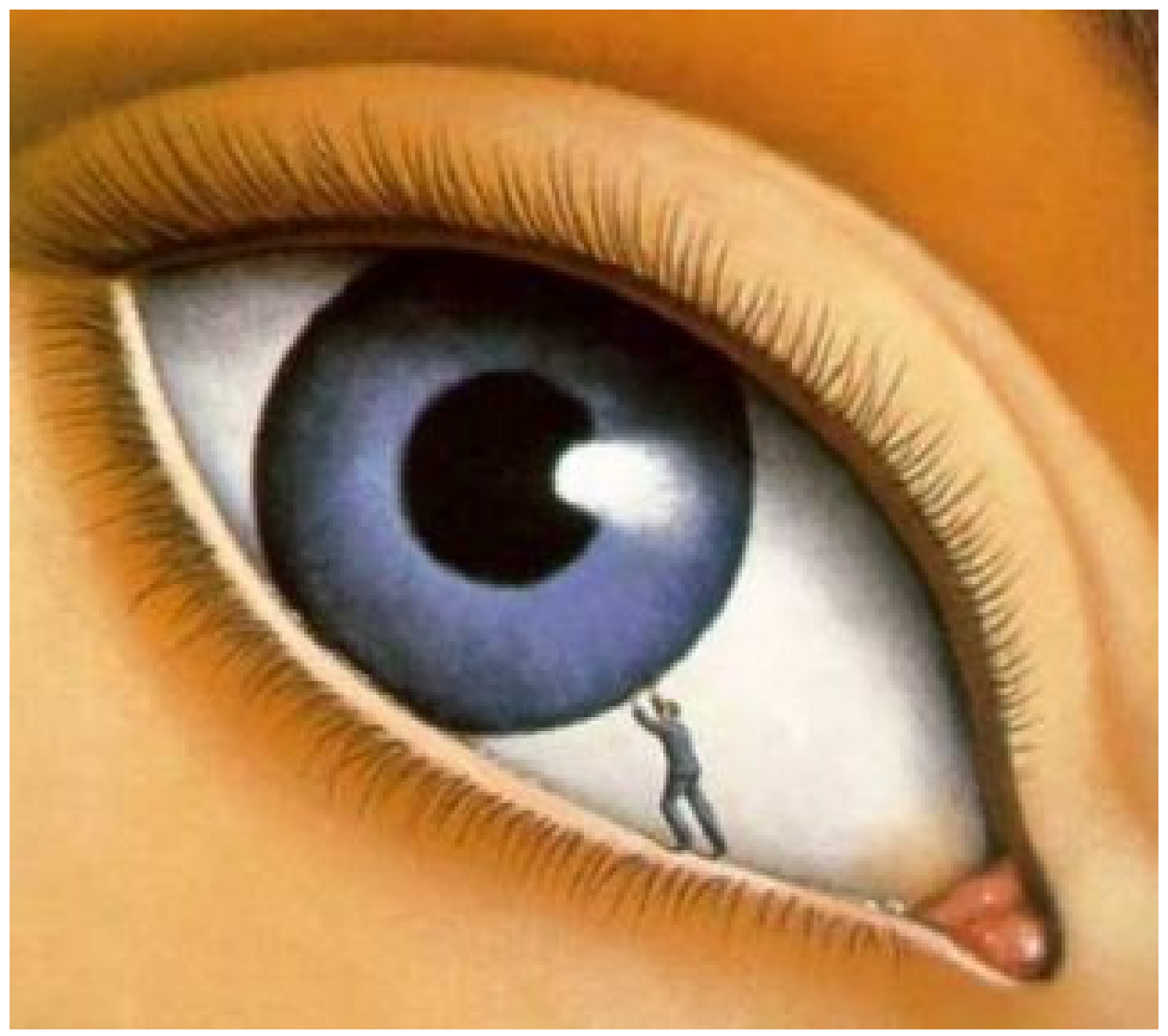

Fonte texto visual: René Magritte. In: Retrospective in Rotterdam, 1967. 


\section{6 - DISCUSSÃO}

A discussão será dividida em partes.

Começaremos com uma síntese de cada sessão que foi montada a partir do movimento ocorrido nas mesmas, agora no formato de cenas, as quais relacionam personagens, temas e vetores de forças no jogo relacional. O título dado a cada sessão corresponde ao tema predominante do movimento ocorrido na mesma.

Em seguida, discutimos a ação formativa e seus personagens; os lugares subjetivos ocupados de maneira recorrente pelas formadoras pesquisadas; e o lugar de diferença singular de Clara, a partir das relações institucionais.

Encerramos o capítulo com uma análise da relação produzida no grupo entre todas as participantes e a atual pesquisadora e depois, trabalhamos a experiência da AID em ato e com grupo, feita nesta pesquisa.

\section{1 - Cenas e a relação entre os personagens: uma síntese}

\section{$1^{\text {a }}$ sessão - Atualização das relações e as oposições.}

A primeira sessão é composta por duas cenas. A primeira cena é presente como um pano de fundo e começa desde o início da sessão com a fala da pesquisadora propondo as sessões em grupo para sua pesquisa; o modo como propõe o trabalho e o fato de estar se reencontrando com as participantes possibilitou a repetição, bem como a atualização das relações afetivas do passado entre a pesquisadora e as mesmas. Do lado da repetição encontramos o enaltecimento do grupo antigo (Grupol) e a expectativa das boas relações, a identificação em relação à mesma concepção de trabalho, a relação de concordância e de complementariedade lá compostas. As expectativas de desabafar e buscar o apoio do grupo foram também repetidas. $\mathrm{Na}$ atualização das relações encontramos tentativas da mediadora de ocupar novos lugares na relação: lugar de diferença (sair do consenso), de estranhamento (de 
falas), de desconhecimento de situações concretas (pedia esclarecimento e exemplos atuais), de oposição (o que trouxe desconforto e tensão).

A segunda cena é construída por uma série de oposições que, a partir de temas variados, criam lugares valorizados e outros criticados, desvalorizados. A primeira oposição divide os grupos em bons e ruins. De um lado fica o grupo de pesquisa, identificado ao Grupo 1 (do passado) representado como um grupo bom: tem compromisso político, trabalha, defende o que acredita, produz, é responsável, entre outras características. De outro lado, o grupo com o qual trabalham atualmente e que tem muitas faltas (são grupos diferentes, mas unidos nas características comuns trazidas): difícil de trabalhar, com pessoas acomodadas, descompromissadas, que criam obstáculos ao trabalho que recebem de formação, que enrolam, reclamam, não têm argumentos teóricos, não acreditam no aluno, entre outros. Esta oposição produz uma identidade ao grupo de pesquisa em relação a outros grupos.

A segunda oposição compara educadores que recebem a formação: de um lado os que se envolvem, aceitam a formação (e às vezes até brigam, mas estão presentes) e de outro, os que não se envolvem ou que desistem.

Uma terceira divide a resistência como boa e ruim: quando exercida para evitar encarar as "faltas" dos profissionais e o compromisso é tida como ruim, quando exercida politicamente para se opor, argumentar, não aceitar uma orientação com que não concordam, é boa.

Uma quarta oposição define o que é formação para elas e o que não é: formar é fazer pensar, problematizar, mudar. E não é: cobrar, impor, mandar. O cenário da formação é apresentado como guerra, briga, com uma prática cheia de conflitos entre expectativas.

Uma quinta oposição é proposta pela mediadora e produz uma divisão na relação de consenso do grupo (com ela e entre si), ao procurar separar a experiência deste grupo que se reuniu para a pesquisa com relação à passada (com o Grupo 1). 


\section{$2^{\mathrm{a}}$ sessão - A caracterização da cena da formação: a implicação, as queixas, e as resistências.}

O início da sessão começa com uma tentativa de analisar a posição assumida por uma delas num dado momento da formação vivida, o que coloca o grupo de pesquisa na cena da formação continuada em serviço. Muitas são as queixas colocadas. A cena nesta sessão pode ser considerada uma só: a conversa sobre a formação de educadores. Com a ajuda da experiência de todas vão definindo a formação como: defesa numa guerra, ou como lugar de ataque e de morte de sonhos, lugar de sobreviver (através de mecanismos como o da remoção), lugar de viver mudanças questionáveis (como as que interrompem trabalhos e deixam as formadoras de "luto", como as que "fazem de conta que avaliam" e nada muda de fato), lugar de conflitos relacionais de toda ordem (entre diretora e coordenadora, entre equipe técnica e administração, entre professores e seus formadores), lugar de se submeter, lugar de resistir a (que pode ser bom ou ruim, como já apareceu na primeira sessão), lugar de excluir (quem é desonesto, irresponsável).

A mediadora faz intervenções na linha da implicação (para que saiam da posição de externalidade em relação à questão apresentada) e das oposições (como na sessão 1) e cria certa instabilidade nos consensos (usa também a ironia, e é insistente). O efeito é uma abertura temporária para pensar diferente e uma certa "irritação" com a mediadora, que sai da posição de estar ao lado delas, para uma posição mais isolada e de frente. Chama a atenção a positividade que depois desta instabilidade aparece na cena da formação: lugar de esclarecimentos, de quebra de repetição da burocracia, de resistir a ordens autoritárias produzindo projetos coletivos, etc.

O lugar do resistente ocupou uma nova significação, agora de produção de movimentos: quem resiste se desafia, se relaciona, muda de lugar, avança.

E mais uma vez, o movimento inicial volta encerrando a sessão num retorno ao começo: queixas sobre o universo da formação continuada e busca de atribuição de culpas (e o movimento de colocar fora do jogo a solução dele). 


\section{$3^{\text {a }}$ sessão - O lugar do formador: mal-estar profissional e choque de expectativas}

Podemos montar algumas cenas a partir desta sessão. As duas primeiras cenas dizem respeito à formação continuada em serviço; a mais recorrente é a que estão em posição de receber uma formação da administração pública atual e que não reconhecem como válida (a formação é ironizada e desqualificada). A formação recebida tem muitos problemas (avaliação de "faz de conta" ou que produz culpados, cultura da queixa, mecanismos institucionais de opressão e repetição, entre outros). Nesta cena falam como fazem para sobreviver e resistir (no sentido de permanecer) neste lugar e trazem também muitas comparações com grupos anteriores que foram referências de boas formações. Tais grupos ou pessoas são caracterizados como: ousados, pensantes, realizadores dos sonhos de educação, entre outros. Os personagens presentes e em constante tensão são os administradores da gestão atual, os formadores da atual gestão, elas (membros deste grupo de pesquisa), os colegas com os quais se identificam e outros com os quais não se identificam.

$\mathrm{Na}$ segunda cena, elas fazem a formação de professores e olham a produção dos mesmos e dos alunos, mas isso aparece muito de relance, os personagens em cena são elas e os professores, o dilema presente é como "formar sem matar e sem formatar".

Uma terceira cena diz respeito à relação da mediadora com as participantes e entre as participantes. A mediadora faz pedidos ao grupo: sair do silêncio, lembrar a sessão passada, falar do que é formar do lugar delas, "enterrar o Grupo 1", falar da relação com professores e alunos que "parece longe", não ficar na queixa. Entre elas, estão em consenso a maior parte do tempo. Vivem algumas quebras do mesmo, com ajuda da mediadora e de uma ou outra colega que discorda ou questiona. Elas fazem, ao final, pedidos para a mediadora: falar da formação com seus professores e alunos, poderem se queixar (e não serem "recalcadas" pela mediadora). As expectativas, quando atendidas, colocam todos do mesmo lado, e quando não atendidas, separam o grupo em oposição.

Uma última cena é a do funcionário público: deste lugar sentem dificuldades e vergonha, são desvalorizadas (o lugar do funcionário público municipal num certo momento é definido como um precipício), recebem uma imagem social e familiar ruim (ganham mal, são vistas como quem abona mesmo sem precisar), são mal tratadas (“como uma imbecil”), têm uma realidade dura (têm razões para queixarem-se). 


\section{$4^{\text {a }}$ sessão - O "labirinto",41 da formação (desafios, repetições e possibilidades)}

A partir da última sessão podemos montar as seguintes cenas: a primeira parece uma constatação em ato da circularidade das sessões da pesquisa (começam onde a outra terminou, os temas e posições dos atores vão e retornam). Esta característica também aparece no lugar do formador na prefeitura (que vive o ciclo circular a cada mudança de gestão: surgem novos caminhos para a formação, mais uma vez vão se identificar ou se opor a eles e assim por diante).

A segunda cena, mais uma vez, apresenta a formação, mas agora com alguns elementos novos ou mais enfatizados.

A "brecha" no sistema municipal e suas demonstrações, a descrição da formação como lugar de se realizar, como uma ação de desestruturar práticas, mexer com as posições dos profissionais e com isso melhorar as práticas educacionais e as relações na escola. Tal ação é identificada como produto de uma boa formação - "desestruturar" é bom, é desejado. A formação é apresentada por suas positividades-potencialidades: leva a conhecimentos, trabalha os grupos, aproxima da sala de aula e ajuda a melhorar as práticas dos professores em relação aos alunos, problematiza o que poderia melhorar.

O que é difícil na formação retorna mais uma vez: a repetição, o modismo que se alterna, as novas verdades que são impostas, as novas ordens das novas gestões educacionais (e criadas também por elas), os embates, os vetores de forças direcionados a romper com o instituído que insiste em voltar e aprisionar.

A entrada da teorização e da generalização traz o movimento já conhecido de responsabilizar entes abstratos (portadores de vontade e intenção) pelos problemas da educação como "a sociedade", "a escola".

A terceira cena apresenta a coesão entre os membros do grupo (parece, em muitos momentos, haver uma só pessoa falando com a mediadora, talvez por ser esta a última sessão?). Os cortes produzidos na coesão (pela mediadora e por uma ou outra integrante) 
trazem a possibilidade de pensarem de forma diferente entre elas, mas são fugazes e em seguida, mais uma vez, aparece a tentativa de harmonização (incorporando - aceitando o ponto de vista divergente). A quarta e última cena apresenta as contribuições do exercício das sessões em grupo, tal qual reconheceram, afirmaram as participantes: conseguiram ter maior clareza do seu lugar atual, pararam para pensar, usaram o espaço para ouvir o outro, para falar e buscar melhorias, tomaram distância e revisaram posições (e verdades), constataram que a formação é um espaço de lutas ("faz parte, vão ter né”).

\section{2 - Desenhos, marcas e possibilidades da formação e da subjetividade}

Dos textos freudianos, Guirado (2009) destaca um trabalho de 1925, "O bloco mágico", que vamos retomar aqui para nos ajudar a trabalhar a questão da singularidade. Neste texto Freud coloca que cada pessoa recebe estímulos do mundo interno e externo que capta com seu aparelho perceptivo. Os traços feitos pelos estímulos e recebidos pelo sistema consciente e pré-consciente se esvanecem ou são enviados para o sistema inconsciente e se tornam marcas permanentes. A memória dos traços retidos pode ser parcialmente acessível pela consciência e parcialmente desconhecida e não acessível, ficando nos limites do inconsciente.

O "bloco mágico" é um invento como uma prancha de escrever que tem em sua base um bloco de cera e acima dele, duas folhas presas na extremidade, uma primeira é um papel fino e encerado e a segunda um tipo de celulóide. Freud (1925-1976, p.290), a respeito dele, diz: "se imaginarmos uma das mãos escrevendo sobre a superfície do Bloco Mágico, enquanto a outra eleva periodicamente sua folha de cobertura da prancha de cera, teremos uma representação concreta do modo pelo qual tentei representar o funcionamento do aparelho perceptual da mente". As marcas que se tornaram permanentes, impressas no bloco de cera a partir das folhas, recebem constantemente novas impressões, formando desenhos que se sobrepõem uns aos outros.

A partir desta metáfora sobre o funcionamento mental, podemos entender como as marcas que são sempre relacionais-institucionais-históricas formam desenhos que são 
composições psíquicas complexas e singulares. A singularidade é entendida como registros de experiências próprios e que se alteram a cada nova reimpressão.

\subsection{1 - A formação, os formadores e os educadores}

Com a ajuda de Guirado (2009) compreendemos a prática da formação continuada de educadores em serviço na prefeitura de São Paulo como instituição: uma prática na qual relações sociais - profissionais são exercidas e repetidas. Ao longo da repetição legitimam-se lugares para os atores institucionais e as relações entre eles é reconhecida como sendo (ou devendo ser) de um determinado jeito, criando uma filiação discursiva e campos de pertença sociais (os reconhecimentos e os estranhamentos delineiam os limites das comunidades, mostrando o que são e o que deveriam ser para pertencer a elas).

Os atores participantes da instituição podem ser divididos, segundo Guirado (2009, p.37) em agentes e clientela: "cabe ainda destacar que toda instituição, basicamente, se constituiu na e pela relação de clientela; isto é, na relação de agentes institucionais com os clientes dessas instituições. Estes últimos demandam um determinado serviço e os primeiros se destinam a prestá-lo". Os agentes são todos os que fazem e/ou pensam a ação e reivindicam os saberes sobre o objeto institucional: a formação continuada em serviço. Na relação entre agentes e clientes há uma "tensão entre posse e alienação do objeto institucional. Uma relação de poder, portanto, um jogo de forças - poder e resistências, que não se dá senão no e pelo discurso" (GUIRADO, 2009, p.37). Na formação, a disputa de forças se dá em torno da delimitação dos caminhos e saberes a serem escolhidos para o trabalho e que opõem dois vetores: de um lado alguém ou um grupo querendo formar, influenciar, promover mudanças, de outro os que acolhem ou os que não aderem e/ou oferecem resistência, criando uma tensão.

Podem ser considerados agentes os profissionais que fazem e/ou influenciam a formação (reivindicando os saberes sobre ela) e que podem ocupar os seguintes cargos: os administradores públicos, os políticos, os supervisores, os especialistas contratados de outras instituições públicas ou privadas, os profissionais que são servidores municipais deslocados de suas funções concursadas, os diretores, os coordenadores, os orientadores, os assistentes, entre outros. 
Os clientes são os personagens que receberão diretamente o serviço: os professores. Porém, outros profissionais que exercem diferentes funções, também podem receber a formação continuada, como: os inspetores, pessoal de cozinha, da limpeza, do administrativo, profissionais das equipes diretivas (supervisores, diretores, coordenadores, orientadores, entre outros).

Chamaremos os clientes pela nomenclatura de educadores (aquele que recebe o serviço da formação continuada em serviço) e os agentes, de formadores (aqueles que oferecem o serviço).

Os alunos podem ser considerados uma clientela indireta, pois receberão o serviço da formação continuada a partir da influência que a mesma tiver sobre seus educadores em geral (os que lidam com ele no cotidiano escolar). As famílias são personagens que também recebem, indiretamente, a influência da formação continuada, através de todos os agentes com os quais lidam nos diferentes cotidianos escolares (em práticas nas quais sua presença é consentida e esperada como nas visitas, adaptações, festas, reuniões, palestras, conselhos de escola, entre outras).

Os alunos não foram o foco escolhido para orientar os recortes produzidos na revisão bibliográfica, mas ainda assim aparecem como grande preocupação, no sentido dos educadores terem que enfrentar a dificuldade de ensinar a todos (alunos vindos dos variados estratos sociais, e com perfis e interesses diversificados) e de combater a repetência, a evasão, a indisciplina, o não aprendizado ou a falta de interesse dos mesmos.

Os alunos aparecem muito pouco no discurso das educadoras formadoras pesquisadas, o que chama bastante a atenção. Elas ocuparam o tempo do trabalho no grupo muito mais com o a discussão sobre o formador e as políticas públicas, do que com os alunos. Quando os mesmos apareceram, ocuparam o lugar de indefesos frente a ações tidas como "inadequadas" por parte dos adultos que com eles lidam ("serem lavados com água da privada", "terem uma festa na qual se oferece comida que não têm como pagar", "receber como atividade desenho mimeografado", entre outros) ou o lugar de inadequados - o que coincide com o discurso acadêmico (“jogar os cadernos fora”, "desinteressados, desrespeitosos, indisciplinados”). De maneira indireta a positividade com relação aos alunos (o que eles aprenderam) aparece quando descrevem suas produções, festas, exposições e reuniões de pais. As famílias também não fizeram parte do foco que produziu os recortes na parte da revisão bibliográfica, mas 
aparecem como solicitantes dos serviços educacionais e, historicamente, como agentes e concorrentes dos religiosos, muitas vezes na posição de controlar as práticas. Com relação às escolas públicas, elas são citadas nas experiências dos conselhos, e são mostradas como tendo dificuldade em gerenciar o dinheiro público, a distância geográfica, o horário das reuniões, as relações com o corpo diretivo da escola que, por sua vez, deixava claro que a presença dos pais era "trabalhosa", teoricamente justificada (cidadania, protagonismo, democracia, parceria), mas muitas vezes, não quista. Além dos conselhos, as famílias são convidadas para assistir ou participar de práticas dentro das escolas, algumas dirigidas especialmente para elas. As relações com as famílias são muito discutidas e estudadas nas práticas de formação, mas nas discussões deste grupo de pesquisa também apareceram pouco e na relação, as famílias ocuparam a posição de vítimas (são julgadas pelo padrão de família normal-anormal em suas composições relacionais) ou de inadequação - o que coincide com o discurso acadêmico (respondem avaliações institucionais "capciosas", sem crítica, interferem no pedagógico, defendem seus filhos e não o coletivo dos alunos, entre outros). As famílias foram em alguns momentos colocadas como adequadas e parceiras, e assim, positivadas na relação entre as formadoras e famílias (ajudaram a construir uma festa mais democrática, por exemplo).

Como pudemos observar, encontramos um ponto no qual os discursos dos acadêmicos e pesquisadores, em relação ao discurso das formadoras, coincidiram, quando os temas tratados foram os alunos e as famílias: ambos apontaram a inadequação da clientela, o que mostra o choque de expectativas produzindo conflito.

Na instituição "formação continuada em serviço" há a produção de textos-discursos que organizam os modos de fazer a formação e o modo de viver o lugar do formador. Ao longo dos capítulos 2 e 3 pudemos trazer muitos textos-discursos que são práticas discursivas que apresentam modos de fazer e reconhecer a formação e, neles, os lugares dos agentes e da clientela. Observamos como os modos e lugares foram sendo modificados ao longo do tempo e chegamos ao tempo atual, que, de forma recorrente e hegemônica, a partir dos autores escolhidos pela atual pesquisadora, reconhecem e valorizam como formação aquela que vai trabalhar para fazer dos educadores seres reflexivos, pensantes, estudiosos, críticos, sensíveis, pesquisadores, criativos, conscientes de sua história pessoal e de classe, afetivos, compromissados, participantes, protagonistas, democráticos, capazes de ensinar e aprender, e de transformar para melhor a realidade educacional. Os formadores, por sua vez, precisam conhecer bem o que vão ensinar (conteúdos e competências acima elencados) e para isso 
devem ser "profissionais da formação" (aqueles que tomam a tarefa da formação como o seu compromisso e a sua identidade profissional). Em oposição, desvalorizam e querem combater com a formação, o educador "técnico-executor", passivo, não participativo, dependente, não crítico, incompetente, que mantém o status quo, entre outros perfis. Desvalorizam também o formador eventual, o que desconhece o conteúdo específico da formação e a oferece de forma fragmentada.

A relação formador-educador (agente-cliente) aparece como conflituosa, e muitos problemas são levantados, discutidos e ao final, há sempre uma proposta de trabalho que dá continuidade aos esforços da formação. A clientela "educador”, também é responsabilizada pelos problemas enfrentados nas práticas de formação, o que ocorre tanto nos discursos teóricos como nos discursos das formadoras pesquisadas, como veremos em seguida.

Um modo de enunciar comum e repetido, encontrado em muitos textos e discursos trabalhados, colocou o formador no lugar de quem observa, estuda, avalia (e identifica falhas), planeja (propõe correções e modificações no rumo dos trabalhos) e, assim, idealiza as mudanças educacionais desejadas e necessárias em cada período, reintroduzindo a ideia de esperança a cada ciclo. O uso de expressões como: "deve ser", "deve fazer", "tem que", "precisa ser", foi recorrente, estabelecendo como que um "contrato" que organiza o modo como falam; apresentam a questão, a experiência a ser analisada ou o problema, e, a partir da problematização, explicação, os caminhos que deveriam ser trilhados e que se apresenta como possibilidade ou promessa de "solução" dos problemas, contradições ou insuficiências encontradas. Vários textos colocaram o autor no lugar de quem ensina e idealiza os caminhos em busca de transformar a realidade para "melhor" e com isso, buscaram "adeptos-parceiros" para seu programa ou sua proposta.

Os agentes-formadores e a clientela-educadores foram personagens muito discutidos também nas sessões de grupo e a tensão relacional (expectativas cruzadas, jogos de forçainfluência e frustrações) entre eles se mostrou sempre presente, confirmando e somando-se à ordem do discurso institucional da formação.

Em muitas situações, porém, a clientela e os administradores públicos (agentes específicos da formação e que mudam - ou não - a cada ciclo político) foram responsabilizados isoladamente pelas dificuldades da ação formativa exercida pelos agentes e foram posicionados como um terceiro excluído que recebe as críticas e que está localizado 
fora da relação. As cenas da formação repetidamente montam tais personagens em força de oposição. De um lado, as pessoas deste grupo (as formadoras ou educadoras que recebem a formação) nomeadas e reconhecidas entre si com um mútuo compromisso político, educacional e social: declaram e defendem suas concepções, veem-se como responsáveis, produtivas, interessadas, democráticas, estudiosas e buscam saídas para as dificuldades vividas na formação continuada em serviço na escola pública. De outro lado, oscilam os personagens-educadores que precisam ser formados e os formadores ligados à administração. Dentro do grupo de educadores comentados pelas formadoras, há professoras que resistem à formação (caracterizadas como descomprometidas, reclamonas, incompetentes, sem fundamentação para o que fazem, desistentes, entre outras) e as que aceitam a formação (e são descritas como profissionais que têm o que dar, produzem, têm energia para o trabalho, são comprometidas, se posicionam e brigam pelo que querem). Outro conflito bastante presente entre o formador e educador se dá em torno das expectativas da parte dos educadores. Os formadores declaram suas concepções de trabalho e mesmo assim os educadores esperam deles algo "incompatível" com sua maneira de trabalhar (dar planejamentos prontos, usar o espaço da formação para "passar" o tempo, definir formatos de festas sem escutar o grupo, entre outros).

Os administradores atuais e/ou seus representantes e seus programas são apresentados, porém, como o maior obstáculos ao trabalho delas (mesmo quando apresentam uma formação que consideraram "boa", pois, nestes casos "lhes faltou” a posição política e a crítica).

O "jogo" relacional da formação foi muitas vezes representado como guerra: "ação de matar ou de morrer", como disputa por saberes, como uma prática de excluir quem não se adapta, quem diverge, quem não tem o perfil. Este jogo atinge o corpo e a alma (“dá dor de estômago, flagela"). A formação desenha uma série de expectativas que são jogos de forças que movem as relações: no lugar do formador há a expectativa de ensinar e no lugar do educador, a de aprender. As dissonâncias entre os lugares idealizados e vivenciados concretamente "matam os sonhos uns dos outros" e tornam a convivência cheia de conflitos e frustrações. As alegrias do trabalho da formação são alcançadas quando a aprendizagem se efetiva, ou seja, quando o formador é reconhecido como alguém que tem o que ensinar, ensina e seu educando aprende, cresce, melhora, transforma a si e a sua prática educacional, contribuindo para a melhoria da escola pública. 
$\mathrm{Na}$ prática da formação continuada em serviço de educadores na prefeitura de São Paulo há uma característica de funcionamento e organização que coloca, algumas vezes, a mesma pessoa no lugar de cliente e agente; criando uma superposição de lugares. Isto aconteceu ao mesmo tempo (o que ocorreu no caso do coordenador pedagógico, por exemplo, que recebe a formação do grupo da administração da prefeitura e faz a formação dos professores de sua escola) ou numa espécie de rodízio (por alguns meses ou anos passaram a ser um formador e em outros, a ser o cliente da formação). Todas as pessoas que compuseram nosso campo de pesquisa vivem ou já viveram a situação "mista" acima descrita.

As marcas dessa vivência "mista" se mostraram muitas vezes como ambiguidade, como uma "confusão" entre os personagens, que pode ser vista com o uso do "a gente" indefinido que precisou ser confrontado nas sessões, para esclarecimento: "a gente quem?". Muitos são os grupos que se formaram e compuseram um "a gente" ou um "eles" num dado momento e que mudaram em outro. Quem se posicionou dentro e quem estava fora do grupo dependeu muito da situação concreta relatada e as formadoras-pesquisadas entraram e saíram dos grupos muitas vezes, dada esta situação "mista" vivida. Em alguns momentos apareceu um "a gente" ou um "eles" genérico identificado como sendo "da prefeitura" e que não discriminava os personagens da cena; e que poderia referir-se tanto a elas quanto como a outros.

Elas compreendem o educador em situação de ser formado por outros na prefeitura, reconhecem (mais ou menos) e se identificam (de certa forma) com as dificuldades, resistências ou indiferenças, pois conhecem tal lugar institucional. Do lugar de formadoras, querem mudar a realidade da formação e colocam suas forças nesta direção, vivendo momentos que descreveram como: indignação, depreciação do outro, comparação, exigência, oferta, generosidade, paciência, uso da autoridade, entre muitos outros. Nesta ambiguidade, animam e desanimam, começam, param, retornam.

Quando apresentamos o contexto com a ajuda de Maingueneau (1997) como uma realidade negociada entre os parceiros de fala e o discurso como um modo de enunciação num lugar social, identificamos, nos discursos analisados, a realidade político-educacional como uma marca sempre presente nas relações, caracterizando práticas educacionais "politizadas". As educadoras formadoras conhecem os percursos político-educacionais da prefeitura e as marcas de cada gestão na administração municipal, bem como as teorias e concepções educacionais destas. Em seus discursos, posicionam-se a favor ou contra as mesmas. Fazem 
referência também a direitos e deveres em relação à formação continuada (ter o direito de escolher a formação, o dever de contemplar as escolhas dos educadores, por exemplo). Falam muitas vezes, ainda, sobre as influências sofridas e exercidas (consideradas positivas, eficazes e/ou negativas) a partir ou em torno de programas político-educacionais.

As expectativas e atos vindos da administração, que através de administradores, políticos, especialistas, parcerias com Universidades e pesquisadores, analisam e explicam os problemas encontrados (a partir de dados estatísticos, intenções políticas e/ou avaliações), lançam políticas educacionais que atravessam diretamente as práticas dos formadores. $\mathrm{Na}$ formação, entre a permanência e a mudança do trabalho, identificam armadilhas, controles, situações de "faz de conta", perda de tempo, uma produção de material e programas novos (e descarte de anteriores) a cada gestão e uma sensação "amarga" de pouca mudança.

Ser parceiro na prática da formação continuada em serviço na prefeitura de São Paulo implica tomar posição - a favor ou contra, o que se dá em atos concretos como: participar, negar, escolher, criticar, propor, seguir, romper, atender (ou não) às expectativas, agir no paralelo, recusar, entre outras ações possíveis. As possibilidades ou dificuldades de fazerem escolhas e de participarem em cada contexto político-relacional são ações que definem, constroem e reconstroem o contexto e, desse modo, estabelecem relações de proximidade ou afastamento, e eleição de parceiros para cooperarem ou discordarem. O "jogo" políticoinstitucional implica em identificar "quem é quem", as expectativas (quem quer o que de quem) e as separações (quem está de qual lado). A cada mudança de administração (que ocorre a cada quatro anos) ou na administração (mudanças de secretários, por exemplo) há muito movimento: certos lugares ficam vagos e são reocupados, gerando todo um rearranjo que mobiliza muito todos os envolvidos, promovendo tensão, descompassos, depreciação e/ou remoção (os que não são escolhidos), rotatividade de pessoas, projetos e concepções de trabalho. Somado a este contexto, o mal-estar de formar alguém ("quero formar sem formatar, como fórma e não como fôrma"42). Desta maneira, encontramos na própria "natureza" do trabalho de formação na rede pública muitas das dificuldades tão discutidas pelas formadoras-pesquisadas.

A partir da perspectiva dos lugares institucionais e das expectativas mútuas criadas nas relações vividas na formação, as relações de poder puderam ser identificadas nas ações e 
estratégias através das quais os personagens tentavam conduzir, influenciar e/ou determinar a conduta e os saberes dos outros, e as resistências, nas forças de oposição, de negação, entre outras. No jogo da formação, muitas posições foram encontradas: alguns se posicionam portando "a verdade" e deste lugar ensinam ou impõem os caminhos "certos", outros orientam e formam o outro, a partir de saberes que consideram relevantes (levando mais ou menos em conta os saberes dos outros), alguns desconsideraram a possibilidade de reação do outro (negociação, recusa, embate, desprezo e etc.). Alguns tomaram um tipo de oposição vivida como falta moral, imputando uma característica negativa, de falta de ética, ao lugar subjetivo do outro.

O modo como vivem os seus sentimentos e conflitos e a maneira como se veem na profissão são constituídas nestas relações concretas (e políticas) que fazem cotidianamente e nos lugares “mistos-sobrepostos” ocupados frente à formação.

Os resultados da análise dos textos teóricos mostraram um discurso hegemônico a favor do educador pesquisador e reflexivo, do formador "profissional" (que toma a tarefa como o seu compromisso e a sua identidade) e da formação participativa, crítica e transformadora de si e da escola. Em contrapartida, os discursos das formadoras não caracterizaram tais lugares para si e para o trabalho, o que evidenciou um mal-estar e um choque de expectativas entre os lugares e perfis prescritos e desejados para fazer face aos problemas educacionais no país e os vivenciados por elas no espaço profissional municipal, caracterizado como um espaço do "entre" - em meio a políticas educacionais que se alternam. Com relação ao que combatem e o que desejam que a formação "trabalhe" houve mais acordos: apatia, comodismo, desinteresse, falta de compromisso, dependência, autoritarismo, falta de crítica e posicionamento político, entre outros.

Vejamos agora a caracterização dos lugares subjetivos ocupados pelas formadoras e que construímos a partir das análises. 


\subsection{2 - Lugares subjetivos ${ }^{43}$}

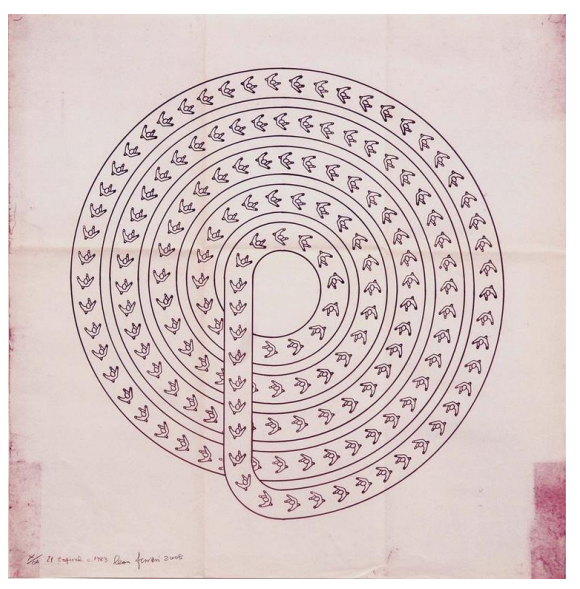

Leon Ferrari, The Architecture of Madness, 2002.

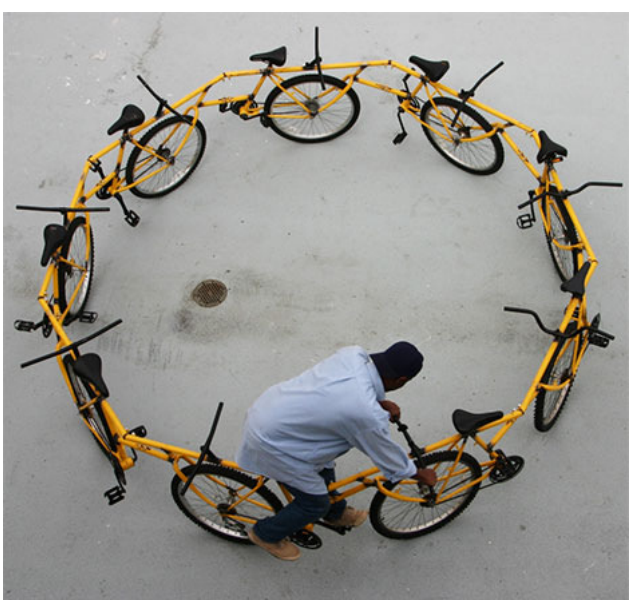

Autor desconhecido. Disponível em: http://www.btt.com.ar/nota/363/363070.shtml Acesso em 02.02.2011.

Tomando a estratégia de pensamento da AID como um caminho para analisar a subjetividade, trilhamos um caminho para chegar às relações imaginadas e simbolizadas pelos que as fazem, no e pelo discurso. Segundo Guirado (2006, p.79) este modo de trabalhar privilegia o lugar "na ordem institucional e não as características ou capacidades individuais e pessoais. Assim os conflitos, os distúrbios, os desvios, as inadequações são considerados como expressão da articulação de posições, e não como sintoma de um indivíduo que está na instituição".

Ao longo da pesquisa bibliográfica encontramos caracterizações a respeito dos lugares ocupados e atribuídos aos formadores e aos educadores, a partir do como apareceram na ordem dos discursos estudados. Demonstramos como tais lugares geraram expectativas e posicionaram os personagens na relação educacional institucional.

Ao longo das sessões em grupo e das análises também encontramos lugares ocupados e atribuídos pelas formadoras para si e seus parceiros e que foram construídos e exercidos nas

\footnotetext{
${ }^{43}$ A partir do referencial da AID e do conceito de sujeito dobradiça, poderíamos falar simplesmente de lugares ou lugares institucionais, mas os termos lugares subjetivos ou formações subjetivas serão também encontrados no texto, como uma escolha pessoal da autora em enfatizar as lentes da subjetividade.
} 
relações concretas de trabalho. A partir dos registros das suas experiências (memórias e representações), tal qual apareceram em seus discursos, identificamos uma circularidade de lugares subjetivos ocupados e atribuídos entre si, sendo que todas as participantes passaram, saíram e retornaram aos mesmos lugares, configurando uma sensação descrita por algumas delas como "estar num labirinto". Dentro deste movimento comum entre elas, identificamos diferenças no modo de ocupação dos lugares e que vamos exemplificar, ao final, com a situação de Clara (a diferença é composta pela história de cada uma - sua sobreposição de marcas institucionais, que comparecem e se constituem na relação).

Com a ajuda de Foucault (1995, p.235), entendemos a subjetividade como efeito das relações e dos exercícios de poder: "Esta forma de poder aplica-se à vida cotidiana imediata que categoriza o indivíduo, marca-o com sua própria individualidade, liga-o à sua própria identidade, impõe-lhe uma lei de verdade, que devemos reconhecer e que os outros têm que reconhecer nele". É a apropriação-sujeição de um saber sobre si que define o sujeito. Assim, o sujeito é definido com alguém sujeito a: sujeito ao controle, à dependência, ao autoconhecimento e constituído pelos jogos de poder e verdade. A sujeição é um modo de subjetivação. A subjetivação ocorre através de formas variadas de responder às prescrições, o que, para Foucault, são condições dadas historicamente (e regionalmente).

Com Guirado (2009) e o conceito de sujeito dobradiça, exposto no capítulo do método, vamos procurar os modos de subjetivação propostos numa prática concreta e sua ordem institucional, mas também, e assim nos afastamos de Foucault, escutaremos as histórias particulares - o como falam, o como se veem na prática institucional (o que reconhecem desconhecem), o que inclui procurar os posicionamentos e representações, acreditando que o subjetivo, nesta dobradiça, daí emerge. Escutamos como cada personagem se vê na relação, como se apropria da pauta discursiva institucional, como se posiciona frente à lógica de atribuição e assunção de lugares e nas relações de poder: o que legitima, se resiste, o que reinventa.

A subjetividade pode ser entendida como o resultado da matriz institucional (ordem do discurso e que de certa forma nos iguala) e das histórias e percursos de cada um constituídos sempre a partir de relações e das "escolhas" feitas (o que nos diferencia).

No exercício do lugar "misto"/superposto de agente e cliente, e de educador-formador, formas de subjetivação dos personagens apareceram de maneira recorrente. Assim, entendendo a subjetividade como efeito dos exercícios relacionais e entrecruzamento de 
histórias (sempre institucionais), apresentaremos as formações subjetivas que encontramos e construímos a partir deste estudo.

\section{I- Recolhimento individual (vitimização, culpabilização, desqualificação)}

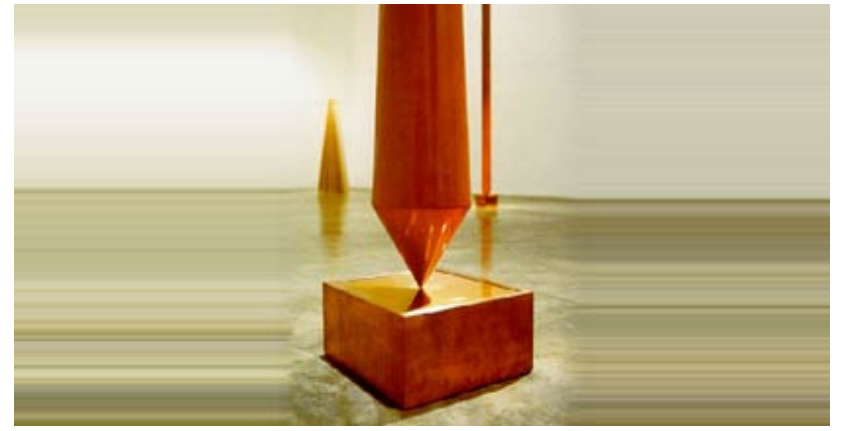

Arthur Lescher, Mastro, madeira, 1998.

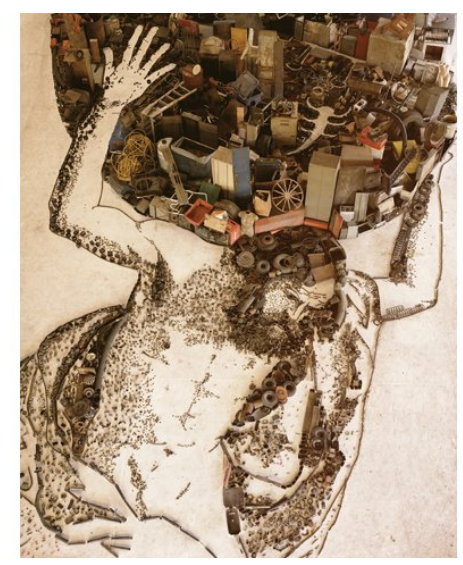

Vik Muniz, pictures of garbage, 2007.

Deste lugar são vítimas (e os outros são os algozes) ou culpadas (e os outros vítimas de suas "faltas" ou "insuficiências") dos e pelos conflitos e problemas que vivem na situação profissional.

Quando o outro-modelo para elas (que pode ser a colega do grupo, a mediadora, ou outra formadora a quem "respeitam") recusa alguma fala ou não concorda com alguma ação (não se chega ao consenso desejado), a tendência é recolher-se no individual, ou seja, apontar para questões individuais (defeitos, faltas em si e boas qualidades do outro).

Quando ocupam o lugar de culpadas ("eu fiquei muito tempo me culpando", "é uma tortura diária", "vai buscar o culpado", "você assume a culpa ou se livra da culpa") as características atribuídas aos outros aparecem como fragilidade ("elas dependiam de mim e eu não fiz nada”), vulnerabilidade ("eu não deixei ela mostrar o que ela sabia”), frente ao "grande saber" ("não era pra eu fazer isso né Juliana). Ao mesmo tempo em que possuem faltas, se veem como impotentes por questões pessoais ("é só minha expectativa não é de mais ninguém”, “eи que tenho que mudar”, “eи é que não consigo”), se responsabilizam individualmente pelos problemas relacionais configurando marcas onipotentes e poderosas, 
tanto em relação ao que fizeram, quanto ao que não fizeram e poderiam ter feito e, assim, resolvido a situação ("não consegui fazer o professor acreditar no aluno").

Quando ocupam o lugar de vítimas, se queixam dos outros e das situações, apontando a impossibilidade de saída ("estou viciada na queixa" ou "faço queixa e recebo queixa o dia inteiro" ou "não há outro jeito"). Os outros aparecem com características fortes, portando grandes poderes ("duas atrapalham todo o grupo, não consegui mudar isso”) e/ou com faltas profissionais, morais e éticas ("são de baixo nível, é um descaso" ou "está numa escola pública e acha que qualquer coisa serve” ou "vão lá passar o tempo da criança”).

Neste lugar de recolhimento individual descrevem um descompasso entre o pensar e o fazer: há uma repetição circular de pensamentos, e, ao mesmo tempo, uma imobilidade de ação concreta, expressa como um "não saber o que fazer", uma posição de desistência, uma paralisação.

\section{II- Sujeição burocrática - (passividade, apagamento de si, alienação)}

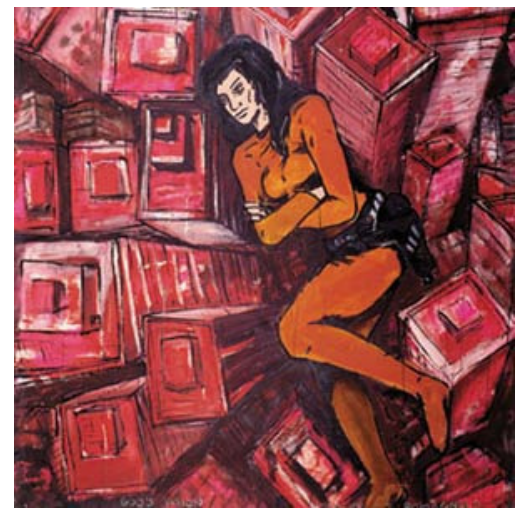

Sérgio Romagnolo, God's Vision, acrílica sobre tela, 170 x 200cm, 1985.

Deste lugar, sacrificam as críticas e sujeitam-se aos procedimentos burocráticos (preencher todas as planilhas que dizem ser "sem sentido"), às exigências da administração ou de seus superiores ("fazer de conta" que avalia a pedido da diretora).

Há uma posição de passividade em relação às demandas que recebem (dizem: "tem que cumprir") e "automação" nas ações (fazer o que pedem é mais fácil do que argumentar, 
brigar, discordar). O que pensam ou desejam não é colocado nem problematizado e atendem aos pedidos e ordens recebidas, se colocando como mais uma peça que faz mover a engrenagem ("cai na engrenagem da prefeitura e alimentei o instituído”). Procuram não pensar nas consequências e quando o fazem, minimizam-nas ("não ia adiantar nada fazer diferente" ou "não quero problemas, faço mesmo sem concordar, nem penso muito" ou ainda: “então, não penso muito pra não me angustiar”).

Deste lugar agem de forma dependente, obediente, e vêem-se "sem saída" (já pensei muito, não há o que fazer”, “vem um pacote educacional e que você tem que cumprir” ).

\section{III- Guerreiras da educação (disputa, resistência, ataque e defesa)}

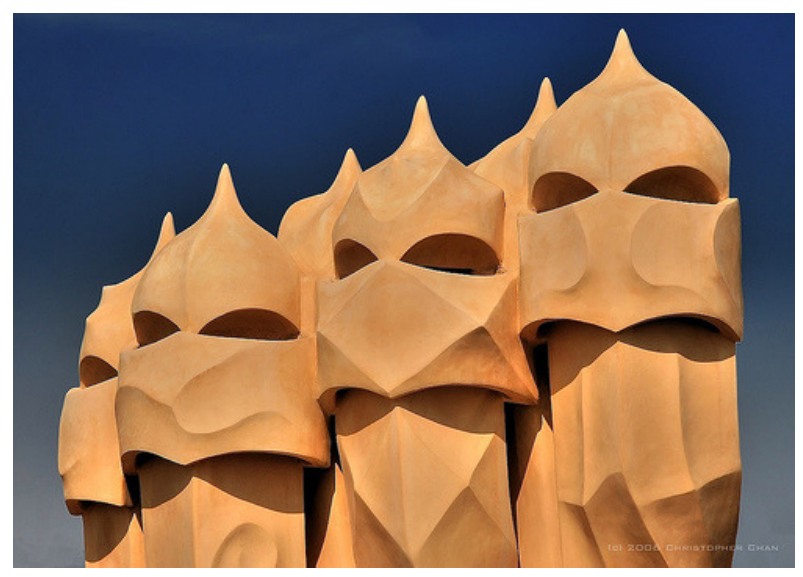

Antoni Gaudí, Casa Milá, 1905.

Deste lugar estão armadas, o outro é o inimigo ou o aliado, a linguagem é bélica ("armadura", "é uma guerra", "briga de todo o lado", "se enfrentavam", "há grupos que ainda resistem", "era matar ou morrer", "silencia pra depois poder nos atacar", "elas brigavam entre elas”, “fala, grita, chuta a porta”).

O cenário da formação é descrito como uma batalha na qual há luta e disputa por saberes-teorias (sonhos em educação) e práticas; um dos efeitos é a delimitação de lugares valorizados para uns e desvalorizados ("como entro na formação sem matar, desqualificar o outro?”) para outros personagens, o que faz com que algumas pessoas sintam-se melhores do 
que as outras ("as vencedoras e as perdedoras da disputa", "as portadoras do saber valorizado" e as "em falta"). Outro efeito é a montagem de grupos e a relação entre eles é estar a favor ou contra ("sair de um grupo de vida e entrar num grupo de morte"); e, entre eles e dentro deles, o exercício do ensino, da influência ("entrar no pensamento do outro- rebocar as pessoas para suas idéias”, “rodei a baiana”) ou da imposição de saberes e práticas, com maior ou menor dominação e autoritarismo ("pelo menos eu assumo minha onipotência”, "tem a questão do poder da minha palavra de formadora”, “as superpoderosas”, “nós somos ótimas mesmo”, "eu dou advertência”, “eu tenho pena”, "quem me substituiu não quis enfrentar o grupo", “estão acostumadas com o cumpra-se”).

A identificação do que combater em relação a quem está no lugar do oponente é chamado de resistência quando identificada como sendo do educador e é entendida como um obstáculo que atrapalha, é negativa e deve ser transposta com a ação da formação e seus métodos; muitas vezes o educador que resistia à formação foi nomeado com características negativas: falta argumentação, falta saber teórico-prático, falta compromisso e ética profissional, ou como comodista, burocrata ("melhor lidar com os resistentes do que com os que não se envolvem ou são sem caráter”).

A resistência produtiva da parte das educadoras que recebem a formação das formadoras deste grupo pesquisado (contrária ao obstáculo) permaneceu no desconhecimento, mas apareceu em diversos momentos como uma ação em resposta à outra ação e que determinou novos movimentos ("resistiram a minha proposta, não fizeram, aí tivemos que endurecer”).

A resistência foi mostrada de forma positiva, produtiva e fazendo parte do jogo quando exercitada pelas formadoras-pesquisadas quando recebiam uma formação (que discordavam e, então, resistiam a ela). Deste lugar, a resistência foi compreendida e apresentada como uma prática consciente e política de busca de mudanças, de argumentação e luta em defesa da liberdade, da autonomia intelectual, do protagonismo e/ou continuidade de práticas que acreditam (do direito por trabalhar a seu modo). As formadoras sabem da sua resistência e a exercem como forma de "luta", para se opor ao "movimento institucional maior". 
A "escola" é vivida como um lugar cujo "jogo" é perigoso ("um meteoro: a escola tá caindo que nem machado na cabeça da gente”, "eu piso em ovos, não sei que jogadas posso fazer com cada um”).

\section{IV - As sobreviventes (aguardar, suportar, permanecer)}

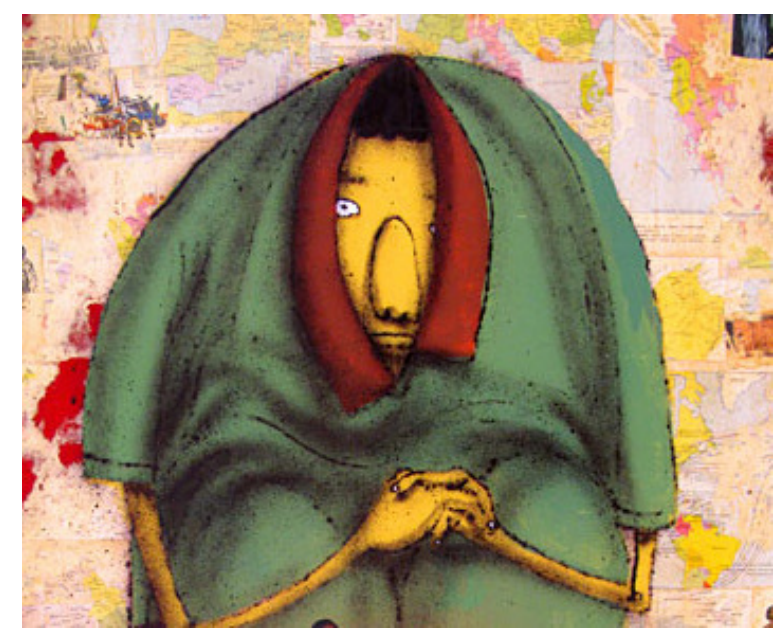

Os Gêmeos, grafite, 2005.

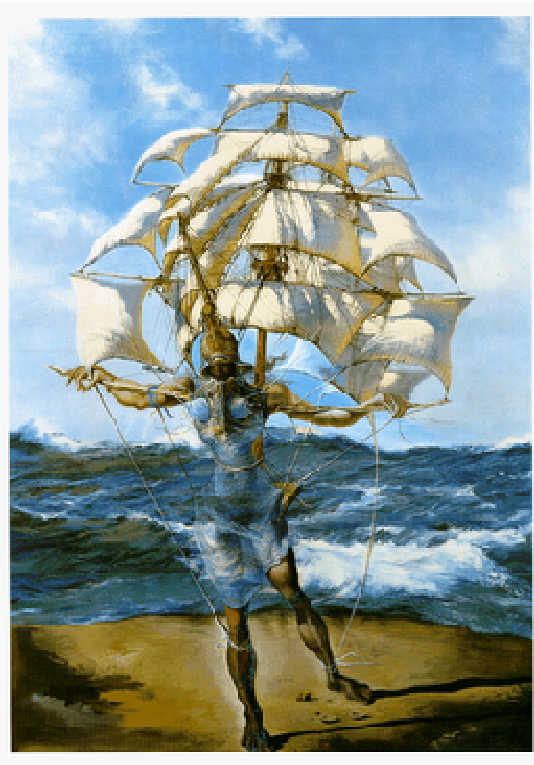

Salvador Dalí, The Ship, oil on Canvas, 1942.

Deste lugar, procuram estratégias de permanência, de resistir no sentido de "conseguir permanecer" (nesse sentido uma resistência produtiva), de insistir ("e foi uma cacetada na minha cabeça”, “mas consegui permanecer aqui”). Um mecanismo institucional é destacado como possibilidade: a remoção. Este mecanismo é usado por todos: os que formam e os que recebem a formação, quando o posto de trabalho se torna insuportável, a remoção "liberta" ("entrei na remoção", "não suportava mais", "tento ficar na formação senão peço remoção"). Serve também para afastar pessoas que "atrapalham" os projetos das escolas, que têm outras concepções e que dificultam as relações de trabalho ("quem não tiver satisfeita é convidada para remoção”).

A energia é canalizada para continuar ("sobreviver ao instituído de uma gestão até que ela mude, acabe") e esperar passar o pior ("não sei não, teve pior que isso?). As ações 
que ocorrem são descritas como "no automático" ("quanto menos pensar, menor será o sofrimento, vamos tocando").

Uma situação bastante comentada é a convocação, um artifício usado muitas vezes para a formação continuada, na qual os educadores e/ou formadores têm que comparecer e participar, respondendo a um chamado da administração ou da equipe técnica da escola.

Frente à obrigatoriedade da convocação ou das decisões do grupo-escola, diversas foram as reações relatadas a partir deste lugar de sobreviventes: comparecem, mas não participam de fato ("eu ficava ali, mas não estava ali", "quando sou convocada pra escutar algo que discordo, não presto atenção em nada, me desligo"), tentam não problematizar ("tentei falar o mínimo que consegui, mas um pouco tive que falar né!"), fazem silêncio ("nunca houve discussão, só que era um silêncio"), falam que concordam com a decisão do grupo, assinam ata e depois fazem a seu modo ("elas assinaram e aí não vieram”), boicotam ( "a sala delas ia ficar vazia, tive que tomar uma atitude"), fazem o que é pedido ("a gente se vê obrigada a fazer muitas coisas também e as pessoas fazem com a maior naturalidade”, “a gente não queria, mas tá sempre cobrando"), fazem de conta ("faz de conta que registra, faz de conta que tem diário, faz de conta que a festa junina é legal, faz de conta que todo mundo quer isso"), entre outras.

Dois modos de trabalhar são identificados pelas formadoras como caminhos para permanecer enquanto a gestão que discordam não acaba: trabalhar com brechas e no paralelo. Trabalhar no paralelo é fazer o que lhes é pedido ou imposto, e ao lado, ao mesmo tempo, fazer o que querem e acreditam ("procurando algumas possibilidades de trabalhar de uma forma paralela a isso (...) quando a gente faz uma reunião com as escolas pra discutir outras coisas, coisas que a gente achou importante e não algo mandado”). A brecha é descrita como uma ação que quer romper o "cerco do controle" ("tentávamos pensar com o grupo como lidar com a imposição”) e fazer a formação à sua maneira, achando e alargando os espaços mais livres ("fazíamos o que acreditávamos", "trabalho no que acho importante em casa”).

Deste lugar, muitos foram os mal-estares e sofrimentos relatados: ter que lidar com remoções, advertências, ameaças, avaliações e controles, experienciar a raiva, a pena, lidar com o "luto" (lidar com as perdas ao mudar de escola, perder cargos e grupos nos quais trabalhava), com a depressão (tristeza, desesperança, vontade de sair da rede e da educação), com o sentimento de "abandono" e não investimento recebido ("é isso que mais eu sinto falta, porque não tenho com quem pensar o meu fazer", “a desvalorização total do professor”), 
com a sensação da repetição (tudo recomeça), ter que viver e fazer escolhas frente a dilemas (“como você vai seguir uma orientação que não concorda?”), viver situações de impotência e submissão, entre outras.

Identificaram, também, uma vergonha de ser funcionário público, como se pertencer e permanecer neste ambiente fosse uma derrota individual. A imagem atribuída ao servidor público é descrita como: "sou funcionário público, ganho mal então posso abonar, folgar, faltar e faço o mínimo".

\section{Amalgamentos (parcerias, apoios e mitificação na busca de iguais)}

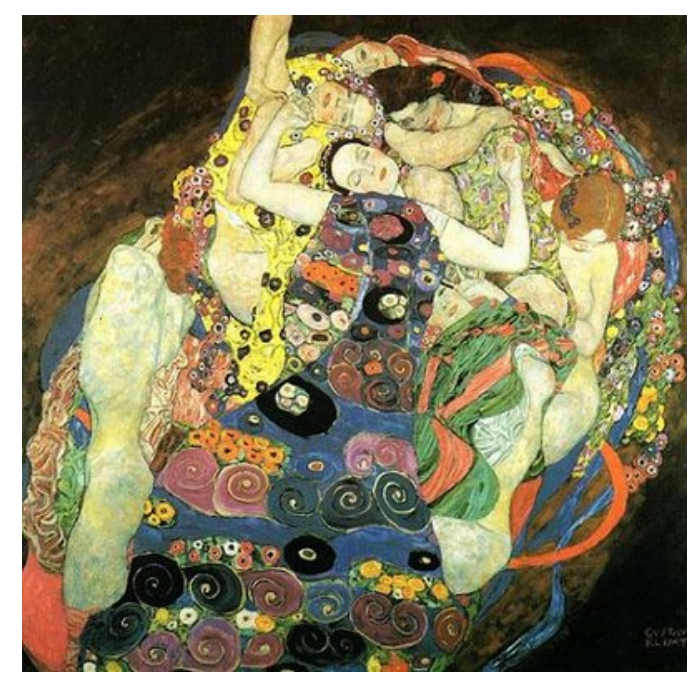

Gustav Klimt, The Maiden, 1912.

Deste lugar as formadoras buscam "os iguais", pessoas com quem possam se identificar (pensar igual, apoiar e ser apoiado), conviver e obter alegrias, além de aprender e ensinar. Buscam também se afastar do sofrimento relacional tão presente em seus cotidianos: trabalham em escolas que não são as "do sonho", com projetos educacionais (e políticas educacionais) que nem sempre concordam ou admiram e com colegas que pensam e trabalham de modo muito diferente, sendo que a rotatividade de profissionais é grande, o que faz com que as adaptações relacionais sejam um desafio constante.

Buscam fazer laços e montar grupos. As características buscadas nos parceiros são: ousadia no pensar, dizer coisas interessantes, pensar e repensar sobre o que sonha e acredita por educação, argumentar, relacionar teoria e prática, ser afetivo e rigoroso, desafiar o parceiro a melhorar, ser crítico, usar o poder de forma democrática, entre outras. 
Um conflito sempre presente diz respeito à homogeneidade buscada, aos consensos tentados e à dificuldade que é conviver na diferença, que por vezes é buscada e positivada e outras vezes, evitada e negativada. Quando a diferença do outro separa, a hostilidade na relação é verificada.

Outra característica deste lugar é a relação de dependência que muitas vezes é tecida junto aos iguais procurados e também àqueles que são admirados e buscados nas suas diferenças para ensinarem caminhos de trabalho que despertem a esperança na alegria da vida profissional do formador.

O amalgamento aparece em muitos momentos, como podemos ver nos seguintes trechos: "mas elas querem ser diferentes", "são diferentes e influenciam as outras, atrapalham o grupo”, “o grupo que tem a mesma concepção não se larga”, "nos sentimos abandonadas e nos juntamos pra sobreviver", "a diretora quer homogeneidade”, "precisamos conseguir um espaço pra pensar diferente”, “o consenso possível da supervisão só vem depois de uma ordem pra todos seguirem um caminho igual”, "a gente buscava um consenso e logo quebrei a cara, não há consenso ali", "pensamos igual, temos as mesmas referências teóricas", "ela sabe como me ajudar", "quando me sinto só e sem saída procuro meu grupo”, “еи busco num formador alguém que eu admire, que possa me ensinar algo que não sei, que apresente propostas interessantes e me desafie a melhorar", "idealizo sim, porque nunca vi nada melhor, era o melhor”, “ a gente trabalhou tanto juntas que tanto faz quem coordenava, tudo fluía muito bem, todos diziam que éramos iguais”, entre outros.

\subsection{3 - A circularidade e os ensaios (repetição, retorno, diferença, liberdade-} ousadia, criatividade)
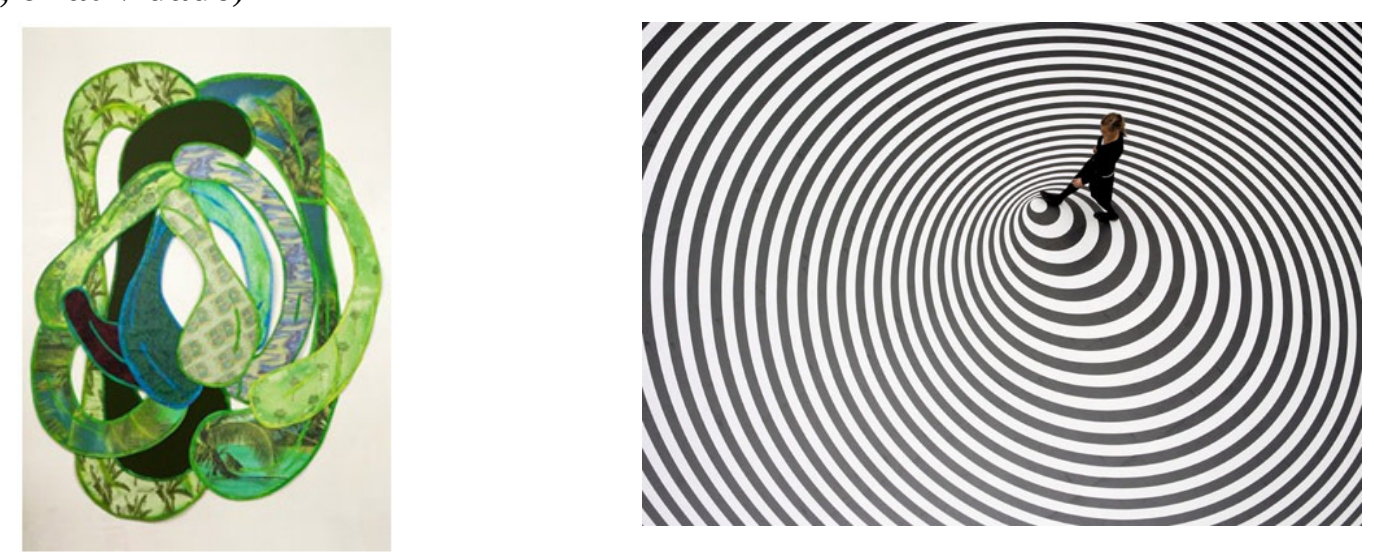

Leda Catunda, Itacare, acrílico sobre tecidos, 243×187cm, 2008.

Optical art, 2006. 
Chama a atenção o movimento circular vivido pelas formadoras-pesquisadas de entrar e sair dos lugares acima trabalhados, tanto dentro de uma mesma sessão como ao longo das quatro sessões. Dentro dos desenhos e marcas relacionais construídos no contexto da pesquisa, encontramos estas recorrências: os cinco lugares são repetidos e legitimados pelos atores institucionais e se mostraram "naturais", não estranhados (como se fosse sempre assim, normais), e encenados continuamente.

Os lugares se ofereceram como espaço de ocupação, um exercício de si, e nele um reconhecimento/desconhecimento (ao mesmo tempo) construído a partir do contexto relacional-profissional e da pesquisa. Tudo isso formou as condições das possibilidades: assujeitamentos e resistências (linhas de fuga).

Outros lugares foram ainda propostos, inventados e ensaiados como possibilidades, o que provocou rearranjos e transformações pontuais como podemos acompanhar a partir dos seguintes trechos: "se você não fez, entrega qualquer coisa, não, não entrego (...) fiz o projeto da escola conforme definimos em e no grupo e só depois do prazo é que entregamos”, “nossa escola recebeu um prêmio”, “meu trabalho é tentar fazer uma ação ter sentido (...) senão não vale a pena fazer”, "eu tenho muito orgulho do que consegui construir - mesmo com todos os problemas, foi possível”, “eu era intolerante”, “agora consegui estabelecer um diálogo, tudo melhorou”, "o grande desafio foi querer alguma coisa do outro e declarei e negociei”, “como é que percebo se o que eu tenho pra dar serve pro outro (...) se expondo, arriscando”, "depois, com a convivência, desconstruímos essa relação esperada, imaginada de mando meu sobre elas”, "é pensar nessas reuniões como momentos privilegiados para se pensar junto (...) valorizamos o possível”, "são grupos que conseguem trabalhar e produzir mesmo em gestões difíceis, mesmo mandados fazer uma coisa não deixam de fazer o que é o projeto deles, da escola”, “o grupo não para, as pessoas não param, não estamos mais cristalizadas naquele pensamento que construímos com você na coordenadoria", "quero fazer a formação sem formatar, faço questão que caibam as singularidades de cada educador, então o programa da formação olha sempre que dá, cada um”.

Nos ensaios de possibilidades as formadoras rompem com as pautas anteriores e apresentam novos arranjos e novas lógicas relacionais. Interessante que nestes momentos os obstáculos e dificuldades ganham novos patamares, novos sentidos e a realidade dura e cheia de impossibilidades se abre, como se todo o cenário de fazer a formação continuada em serviço na prefeitura de São Paulo tivesse sido alterado (o que não ocorreu de fato). Algo se 
deu nestes momentos: modificaram a posição ocupada para significar o seu lugar profissional, o lugar do outro (as expectativas não eram convertidas em evidências, mas problematizadas e/ou combatidas) e a realidade vivida. Vislumbraram senão saídas para o "labirinto", ao menos rotas de fuga (novos caminhos) que romperam um pouco com a circularidade, sempre reencontrada.

\subsection{4 - Singularidade: Clara entre o absurdo e a felicidade}

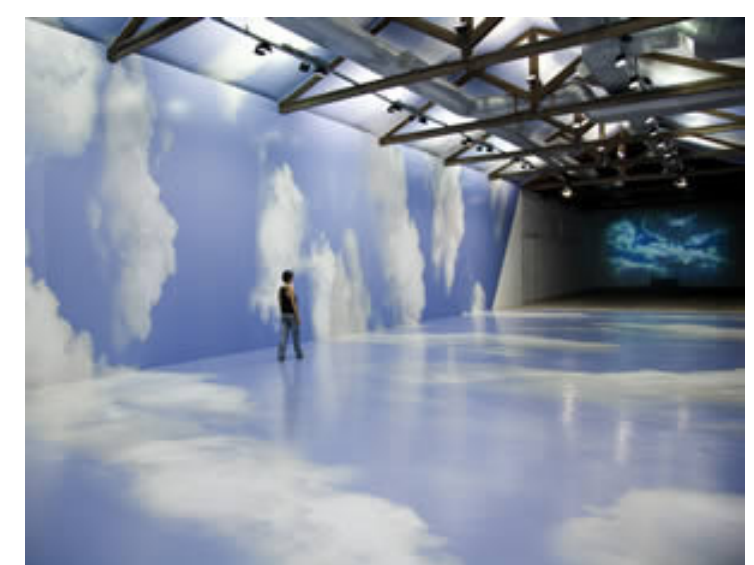

Regina Silveira, Entrecéu, Vinil Adesivo, Instalação, 90 m2, imagem digital,

Eduardo Verderame e Rodrigo Barbosa, Execução, Krom art Studio, 2007.

Quando falamos em ocupação de lugares como lógicas globais que produziram possibilidades para as formadoras, há que se falar ainda que cada uma ocupou tal lugar a seu modo. Apresento agora a educadora-formadora Clara, com seu jeito singular de ocupação e resistência em relação aos lugares construídos na cena da formação. Clara, como todas as outras, circulou entre todos eles, como podemos ver com os seguintes recortes ${ }^{44}$ :

\section{No recolhimento individual:}

"eu fiquei muito tempo me culpando por isso (...) eu buscava muitas falhas em mim", "eu fui escolhida lá, que judiação, eu não sabia nada de CEI", "eu presenciei algumas práticas lá

\footnotetext{
44 Procuramos, para este momento do trabalho, reler as sessões circulando todas as falas de Clara e trazendo as sínteses delas em forma de trechos, como exemplo. As falas repetidas ou muito próximas não foram inseridas.
} 
no CEI que pelo amor de Deus, é um absurdo, tipo, a criança vai no banheiro e você limpa ela com a água da própria descarga", "é incrível como as funcionárias depreciam o ambiente de trabalho ... e as pessoas ( ... nós também, e...é ... faço isso a cada dia”

\section{Na sujeição burocrática:}

"tem hora que desisto de brigar e me deixo levar", "eu acho uma chatice a escola",

"eu acho que a escola não dialoga com a sociedade nunca: não se ouve o aluno nem o professor", "as vezes não sei porque estou na escola", "Na minha escola, toda hora que a gente tinha que assumir uma crítica e correr algum risco, eu ouvia da diretora: não quero arrumar pra minha cabeça, vou dar nota pra tal professora. Isso é repetitivo, não é um absurdo?”.

\section{Na guerra:}

"você discute, fecha a festa junina, por exemplo, e grupo silencia pra poder atacar no dia a dia (...) fica aquele desgaste de uma coisa que foi discutida no grupo", "são muitos os conflitos diários com o grupo", "as pessoas não assumem o compromisso, o político, o social, não põem a mão na massa, é aquela coisa assim: eu finjo que trabalho, você finge que acredita: um absurdo!", "são práticas escondidas que mostram o descaso com a escola pública", "acho que ela traz essa coisa do poder: aqui tem que ser desse jeito", "há diretores super autoritários e coordenadores também", "vão atacar o novo jeito ou defender o antigo?", "prefiro que grite, brigue e se coloque do que essa resistência silenciosa que boicota”, "com ela era matar ou matar...não dava pra ser daquele jeito”.

\section{Na sobrevivência:}

"te deixa sem muita opção de intervir", "vou tocando, uma hora pode melhorar", "fazer o que? Nesse mundo da prefeitura é assim, temos que sobreviver!", "Quando teu grupo escola é muito ruim, pede a remoção!"”

\section{No amalgamento:}

"o que elas incorporaram desse processo fica, o que elas tiverem feito pra me agradar se perde quando chegar a nova coordenadora", "o modismo vira referência a seguir", "grudo 
no meu grupinho quando a coisa aperta", "é tão bom pensar igual, não ter que brigar a cada decisão”, "olho pra ela e ela já entende, é muito bom!”.

\section{Vivendo a circularidade:}

"minha experiência sempre foi o ensino fundamental e cai no CEI", "eu perdi a coordenação do CEI, chegou a nova coordenadora. Estamos todos de luto", "essa coisa de sair da coordenadoria e voltar pra escola tem um peso enorme, absurdo", "então, agora que perdi o cargo, não sei se as mudanças que fizemos vão permanecer, depende muito de quem chegar e quem sair", "se algo muda e é uma ruptura... e até quando...não sei”, "eu sou professora de EMEF, vou voltar pra sala de aula, se não tiver nenhuma vaga pra coordenadora. Estou de luto de novo. Outra mudança, outra vez."

\section{Fazendo seus ensaios de diferença, liberdade e criatividade:}

"demorei pra perceber o que queriam de mim", "fomos falar disso e acertar as expectativas", "muitas das perguntas que me faziam eu dizia: não sei, vamos atrás juntas e eu não sabia mesmo", "Não vou fazer qualquer coisa. (...) Com isso eu quebrei a repetição e agora o projeto saiu e saiu no coletivo, agora sim a gente se vê no projeto, eu e as professoras, que felicidade!", "eu falo das queixas pra mostrar o antes, o que era gritante e as mudanças que aconteceram hoje, pra muito melhor, ganhamos até um prêmio", "quando pedimos pra construir a solução juntas é bom, ajuda, funciona", "estou em estado de graça hoje porque nós fizemos a nossa Mostra Cultural, fizemos a nossa primeira passeata do verde (...) tem muito trabalho em grupo e bom, dá pra perceber a mudança de concepção do trabalho, a criança aparece", "hoje a festa é pra criança, e não pra conseguir dinheiro que deveria vir do sistema público, hoje tem igualdade de condição, que maravilha!”, "de jeito nenhum vou estabelecer uma relação com a comunidade dela estar pagando pelo serviço público", "você mexe numa pecinha e desestrutura tudo", "pra mim é o espaço de cada uma aí, de criação, vai haver uma composição, vamos nos misturar, eu também vou ser influenciada, não é porque sou a coordenadora que só vou ensinar, vou aprender, vou também entrar nesse jogo, mas entrar aberto é o grande desafio", "é que quisemos manter o mesmo modelo de formação, mas já era de um outro lugar, era pra ser outra coisa. Estamos tendo que reinventar, por isso fica confuso às vezes", "a mostra fala dos trabalhos dos professores e das crianças, linda!", "então, essas coisas a gente conseguiu mudar no CEI”, "tem coisas que vou brigar mais, ser mais enfática, outras vou impor pela minha posição de poder que me permite, mas no geral vou conversar. É um jogo relacional, todos fazem, não sou eu a boazinha e elas as más e vice-versa", "e eu mexi no meu lugar a aí mexeu no delas", "eu acho legal é que nesse movimento do grupo(...)acomodado, parado, amarrado, você se aproxima , descobre como eles estão pensando e propõe outro jeito”. 
Como pudemos ver, Clara ocupou à sua maneira os lugares (institucionais-subjetivos) e chama a atenção a quantidade de falas que a coloca no lugar da guerreira e muitos são os trechos que demonstram a vivência da circularidade e seus efeitos, na situação profissional dentro da prefeitura.

Outro aspecto que chama a atenção é a quantidade de falas que são inovações e a colocam pra fora do círculo da repetição. Isso não se dá por acaso ou apenas por qualidades pessoais (história das suas escolhas e experiências), mas também por sua posição no jogo institucional como coordenadora: Clara conhecia pouco das práticas do CEI, não era conhecida pelo grupo-escola como sendo da coordenadoria (como uma profissional atuante definindo e exercendo políticas de formação - "poderosa, sabida"), começou uma relação nova e sem "fantasmas" no ambiente de trabalho, não recebeu tanta pressão e controle da administração (o CEI foi um alvo menor frente a outros segmentos que alfabetizam, prioridade do governo na época), entrou numa escola que não tinha um projeto pedagógico por ser uma unidade recém saída da área da família e bem estar social e ela pôde construir junto com o grupo e a seu tempo o projeto educacional, tinha um diretor que não era pedagogo, o que lhe deu mais autonomia e liberdade, e ela levou ao grupo muitas referências da área educacional (conheciam mais os cuidados).

Clara oscila entre viver os "absurdos" (tantas vezes repetidos!) de seu lugar profissional e a felicidade encontrada como possibilidade.

\section{3 - A relação entre a pesquisadora-mediadora e participantes}

Para efeito de análise procuramos nos discursos os lugares atribuídos e assumidos pelos que fazem/faziam a relação. Na introdução e no capítulo do método deste trabalho, apresentamos um texto que é uma síntese dos trabalhos anteriores da atual pesquisadora com os participantes deste grupo. No capítulo das análises, novos textos são "escritos" pela pesquisadora-mediadora ao longo das sessões (já em nova relação com as participantes). Estes textos compõem o material discursivo da pesquisadora-mediadora. Do mesmo modo, as participantes vieram para a cena da pesquisa com um entendimento sobre as relações do passado e foi na relação atual que tais compreensões foram expressas, retomadas e 
modificadas. Os textos taquigrafados das sessões compõem o material discursivo das participantes e da mediadora.

A configuração de efeitos de reconhecimento e desconhecimento acerca da relação, que se constituiu no interior da rede de relações do serviço público, foi possível pela análise dos discursos nessas quatro sessões. Com ela se chegará a desenhos possíveis, sobre os quais novas marcas serão escritas e inscritas.

Começaremos, numa atitude ousada, quase que colocando a analista e o método à prova (para este tipo de análise), a buscar alguns traços impressos na relação pela pesquisadora-mediadora a partir do discurso da mesma e para isso retornaremos à introdução e ao capítulo de método, e, depois, ao discurso dela nas sessões.

Como disse Lerner (2004, p.29): "fazer análise institucional do discurso é difícil, fazêla sendo membro da instituição estudada é mais". No exercício que esta pesquisadora ora se propõe, a dificuldade se mostra em relação ao distanciamento e estranhamento possíveis sobre sua própria prática institucional, que será sempre parcial. Ainda, segundo o autor, o "estranhamento analítico" quando se revela parcial "está de pleno acordo com a concepção de que matrizes institucionais cumprem um papel importante nas determinações subjetivas, embora não a esgotem” (LERNER, 2004, p.29).

No texto escrito nesta pesquisa na introdução e método, a pesquisadora apresenta os trabalhos anteriores feitos, até chegar à atual proposta de pesquisa. No discurso construído podemos encontrar aspectos da relação da pesquisadora com os grupos do passado e que são trazidos a participarem da construção da relação atual. Traremos alguns que puderam ser identificados.

A pesquisadora apresenta uma preocupação (“o que estaria havendo com elas?") em relação às educadoras-formadoras apresentadas como capazes de "organizar seus estudos, suas aprendizagens e seu lugar de formador" e de se mobilizar e produzir: "Todos os membros do grupo estavam muito mobilizados com os textos produzidos". Elas estariam vivendo uma situação que deixou a mediadora "bastante intrigada", houve um estranhamento em relação à posição delas frente ao conflito vivido: “chamou a atenção na ocasião, como já foi dito anteriormente, o desânimo e a imobilização das educadoras diante dos desafios que diziam estar vivendo em seus locais de trabalho". Houve uma mudança de gestão e a proposta que escreveram foi "engavetada". Era um grupo "coeso", que "fez formação de educadores 
de uma região de São Paulo e influenciou as práticas educacionais segundo uma concepção entendida e definida como 'transformadora' da escola".

Com relação ao seu lugar na relação com elas, é definido como o lugar de alguém que pode ajudar o grupo a "pensar tal prática de formação continuada de educadores, a compreensão dos conflitos relacionais no trabalho e a função do coordenador de grupos" e também a "pensar o lugar de cada um" na formação. Deste lugar escutou queixas: "muitas foram as queixas a respeito do ambiente de trabalho". De coordenadora do grupo passou a participante do grupo (não ocupou mais um lugar diferente e sim igual): "o formato dos encontros mudou muito, a pessoa que apresentava o texto a ser discutido é quem coordenava o grupo naquele encontro, foi estabelecido uma espécie de rodízio e valorizado o caminhar sem planejamento prévio (pauta)”. E: “Propusemos, portanto, uma mudança no lugar da coordenadora do grupo, que não centralizaria mais a coordenação, seria uma participante que ajudaria a pensar e estudar, e não receberia pagamento, como antes, por um acompanhamento do grupo".

Ao longo das sessões encontramos os aspectos acima mencionados, vindos da relação passada, funcionando na relação atual, ativos na construção da nova relação entre mediadora e grupo e eles exprimem expectativas (a mediadora vai ajudar a pensar as relações e a formação, vai "produzir" com elas), pressupostos (qual é função do formador na escola, o que não é um bom instrumento de avaliação ou que uma avaliação deve observar), preocupações (queixas, improdução, imobilidade, depressão), intenções (implicar na queixa), significações sobre o grupo e as participantes (capazes, transformadoras, grupo "coeso").

Vamos mostrar alguns: "Eu entendo que tem uma saudade, que tenha tido um trabalho bom e que tenha a saudade". O termo "saudade" não havia sido usado por nenhuma das integrantes e aparece descontextualizado, apontando para um sentido (expectativa?) trazido pela mediadora. E: "vamos conversar como a gente sempre fez?", "para onde vamos com tanta queixa?", “como se veem em relação a esse queixa?", о "como a gente sempre fez" aproxima, aponta o igual. Nestes trechos a mediadora retoma a preocupação com as queixas e fala do trabalho atual e passado, aproximando-os, ao usar para ambos o mesmo termo: conversar. A última frase tenta uma implicação na queixa.

E, nos seguintes trechos, encontramos pressupostos que reúnem mediadora e grupo numa mesma concepção de trabalho, o que estabelece um "junto" e um "ao lado": "a gente 
nem estranha mais esse nome de feira né?”, "a escola tá ali pra quê? É função dela mesmo!", “o padrão, é, já conversamos isso antes, em relação a família desestruturada”, "isso lembra a avaliação como produtora do fracasso do aluno, no sentido do que ela produz".

Nos trechos seguintes a preocupação com o grupo, a proposta de ver a posição de cada uma na formação, a leitura do movimento do grupo, a função do coordenador de grupos como quem ajuda a pensar e transformar: "como vocês se viram contribuindo, cada uma?”, "o que aconteceu com aquela depressão e desânimo?”, “como cada uma reage a isso?”, "como cada uma vive isso?", "vamos ver o movimento do grupo...", "vamos ajudar a pensar nisso?", "é bacana a gente pensar no que tá construindo nas relações”, "que efeito teve pra cada uma?”, “e a transformação, aconteceu?”.

Os aspectos trazidos das relações anteriores contribuem-funcionam na montagem da nova relação, compondo um desenho próprio deste grupo. Há que se lembrar que, movimentando e participando da composição, estão os aspectos trazidos e colocados por cada uma das educadoras-formadoras.

Vamos apresentar algumas falas que funcionam como uma situação exemplar desse movimento, agora do lado de uma delas. A mediadora coloca a sua marca: "Eu entendo que tem uma saudade, que tenha tido um trabalho bom e que tenha a saudade". Ao que Sílvia responde: “aquele grupo é uma referência pra mim, depois dele não tive outra...", "a gente se sente abandonada", "nos grupos com você a gente não estava só”, "se você quer saber, eu não sei se teria sobrevivido se não buscasse grupos, companhia”, e, depois, ao longo da mesma sessão: "procuro grupos que produzam, como o nosso, pra não morrer no meio da improdução da minha escola e da rede da prefeitura", "o coordenador é uma figura muito solitária na escola”, "eu sinto ... eu não me identifico com as pessoas do meu grupo de rede, acho isso complicadíssimo”, "graças a Deus que existe minha escola e nela procuro construir identificações”. À saudade colocada pela mediadora para caracterizar a relação, Sílvia responde colocando novos traços, a partir de seus significados para a relação: lugar de companhia, de superar a solidão, de identificações, de produção, de vida (sobreviver).

Durante as sessões, uma posição das participantes do grupo em relação à mediadorapesquisadora foi recorrente: tentar atender à expectativa da mesma, tanto com relação ao tema a ser conversado para a pesquisa, como em relação a ocupar o lugar imaginado como o da "formadora". Apresentamos situações também exemplares deste movimento: "Estou no 
caminho certo? Estou respondendo da prática, dos professores e alunos? Você queria isso pra sua pesquisa?” (Clara); "Vocês perceberam que a gente está falando de novo de casos em que não há nada pra fazer e voltando às queixas? Por quê?”(mediadora), "Eu estou tentando não me queixar, porque se eu falar vou me queixar (Risos)” (Amanda); “A Juliana lançou a pergunta: e o aluno onde está nessa fala, nesse discurso? Só ficamos falando das formações e das brigas (...) Eu gostaria hoje então de falar da minha prática que (...) e do aluno(...). (Amanda). E: (...) "eu não quero formar como fôrma, mas como fórma, ou seja, quero que caibam as singularidades do educador, mas quando vejo práticas de professores que discordo, é difícil trabalhar sem acabar desejando 'formatar', quero que ele melhore no que acho que vai mal, aí oriento, claro do meu jeito, puxando pra aquilo que eu acredito. Não é isso formação Juliana?” (Maria).

Apareceu também uma preocupação em ser "correta", em "acertar", atendendo às expectativas imaginadas como sendo as da mediadora e/ou a das colegas, sobre como deve ser ou agir um formador de educadores:

Sílvia - O que você faz quando você vê um absurdo?

Letícia - Depende do absurdo. Uma professora que dá um desenho mimeografado, eu era intolerante a isso. Aí, eu fico pensando: além de um desenho mimeografado, o que essa professora tem que os alunos precisam? É claro que eu vou problematizar o desenho mimeografado.

Sílvia - Ah, bom!

Esse "acerto" entre as participantes para corresponder às mútuas expectativas construiu os consensos nas sessões. As oposições entre os membros do grupo foram tênues, rapidamente acertadas, houve um evitar das tensões, as discordâncias foram "gentis", duraram pouco também. Funcionaram como alimento para pensar diferente, que foi a demanda delas para seus formadores e fizeram parte da definição da função do formador: ajudar a pensar diferente. A familiaridade da mediadora com as pessoas desse grupo e com a instituição "formação de educadores no sistema público" antecipou ou alterou algumas jogadas.

Um saber comum, reconhecido e valorizado, foi construído a partir relações do passado e permaneceu presente nas sessões como uma verdade, podemos dizer, institucional (como ocorreu com o tema do que é fazer formação de educadores, de tal jeito e não de 
outro). As verdades organizaram as relações, marcando as faltas e distribuindo os problemas para quem não pensava ou fazia do modo compreendido como "o certo".

Como pudemos demonstrar a construção da representação de uma relação é uma ação complexa e coletiva, mesmo quando se trata de uma relação entre pesquisadora- analista institucional de discurso e seu grupo. No caso da presente pesquisa, a relação com a mediadora foi um aspecto de muita mobilização no grupo, tanto da parte das participantes em buscar os consensos atuados por todos ao longo das quatro sessões, como da parte da mediadora (e uma ou outra participante) em quebrar os pactos e referências anteriores, produzindo diferenças.

Sabemos que a presente pesquisadora- analista está do outro lado da relação e não ocupa um lugar qualquer, ele está referenciado e afirmado em seu fazer-dizer por um lugar na relação. Um lugar marcado pelas histórias anteriores com o Grupo 1 e por uma filiação antiga; os grupos de estudo e reflexão tal como eram organizados na instituição de pertença (na qual atuou por 14 anos) e uma recente; a análise institucional do discurso. Sobre a nova filiação destacamos dois trechos do discurso da atual pesquisadora (retirado das análises) e que apresentam a sua influência:

A análise institucional do discurso feita em seguida da primeira sessão contribuiu para mapear as posições e os caminhos trilhados, redirecionando o trabalho, no sentido de fazer uma interferência na condução de uma sessão para a outra. Isto fica claro na mudança do lugar do consenso, assumido pela mediadora na primeira sessão, para uma tentativa de diferenciação e distanciamento nessa segunda, o que contrariou as expectativas do grupo gerando mais instabilidade e alguma tensão ao tentar cortes para o grupo trilhar novos caminhos.

E:

Observamos neste trecho os efeitos da experiência de "supervisão" na construção da terceira sessão, constituindo mais um campo de expectativas que também produz os discursos: a pesquisadora-mediadora compreendeu que não poderia deixar o grupo de pesquisa seguir o rumo da primeira sessão (queixas, resistências e retornos ao Grupo 1) e que deveria deixar mais clara a sua demanda da pesquisa. As intervenções são os efeitos do reconhecimento-desconhecimento da mediadora sobre sua função, o que a análise posterior do discurso foi capaz de marcar.

No caso da mediadora, o lugar construído para si a partir da relação com as participantes oscilou entre ser um lugar de proximidade, de cumplicidade, de pensar e ser 
igual, de pertença, e, um lugar que é diferente: está fora do consenso, não busca o consenso, critica (a reação do grupo nesse momento foi de fazer tentativas de aproximação, explicação ou harmonização). Lugar de esclarecer e reorientar com perguntas, de pedir esclarecimento individual sobre expectativas, de fazer cortes que levem a um novo movimento, a pensar. Em alguns momentos a mediadora faz uma oposição ostensiva ao grupo, chegando a usar de repetições, insistência e ironias, como que numa tentativa de forçar um novo entendimento, a nova relação, como podemos ver nos seguintes trechos:

$$
\begin{aligned}
& \text { Mediadora - tem um grupo que não morre? } \\
& \text { [...] } \\
& \text { Mediadora - Bom gente, tá bom por hoje? } \\
& \text { Rita - Tá né? Já entendemos! Chega né? (trecho, s.2). }
\end{aligned}
$$

As relações com a mediadora carregam uma expectativa dada também pelos lugares na relação (antes coordenadora delas e agora pesquisadora-mediadora). Há como que uma autorização prévia ao dito e seus sentidos, uma abertura para revisão de si a partir da fala vinda da mediadora, recebido a partir de um lugar valorizado. Mesmo assim, aparecem sentidos conflitantes, discordâncias, pequenos enfrentamentos de saberes, como podemos ver mais uma vez nos seguintes trechos: "Juliana, sempre tem o que está instituído e é dominante na instituição", "não concordo", "mas você entendeu errado”. E num outro momento uma participante diz: "não é bem assim, Juliana", ao que a mediadora responde com "mas gente, deixa eu explicar melhor". O discurso, como ato, propõe movimentos, controla a ação do outro, subverte, aproxima, separa, convoca, "luta".

Para a constituição dos lugares nas relações, todas as participantes exercem suas influências. O fato de alguém coordenar um grupo ou ocupar o lugar de analista do mesmo, não o isenta do exercício de influenciar e ser influenciado pelos discursos.

Estamos acostumados, em psicologia, a focar e analisar os movimentos do "paciente", do "cliente", enfim, do outro: "o pesquisado". Como se as representações a que se chega nas análises fossem algo individual e interno do "outro", sem relação com a pessoa (seu discurso, o lugar que aceita, recusa ou propõe para si e para o outro) do outro lado do termo da relação. No método da AID, as representações são efeito das relações institucionais e, por isso, 
constituídas no entre, na relação, no discurso. As relações são repletas de expectativas cruzadas que se criam e recriam e se dão em meio a exercícios de poder.

Guirado (2009, p.161) propõe uma retomada do conceito freudiano da transferência e "defende a possibilidade de operar com um conceito psicanalítico, repensado pelos termos de outro discurso, para com ele voltar à psicanálise". A autora reescreve a transferência a partir de Freud, mas já propondo um novo recorte, como um fenômeno que movimenta as lembranças, personagens e falas numa cena que é atuada como repetição e que atravessa o tempo, não respeita as fronteiras e as diferenças de lugares; uma cena que se reapresenta, se reedita. A transferência não ocorre só do lado do analisando e interfere nos movimentos relacionais. É um movimento que pede análise e manejo do analista, quando falamos em psicanálise clínica ou em práticas que trabalham com conceitos norteadores da psicanálise, pois na cena transferencial encontramos as posições ocupadas na enunciação e que, quando trabalhadas, podem dizer "da possibilidade de um acerto básico em que os parceiros se identificam e identificam o outro com uma certa estabilidade de posições”. (GUIRADO, 2009, p.176).

Assim, em nossa pesquisa em grupo, pudemos demonstrar como as relações entre a mediadora e o grupo foram afetadas por algumas expectativas mútuas de assunção e atribuição de lugares.

\section{4 - A AID em ato e com grupos}

O manejo da pesquisadora-analista, a partir do referencial da AID, mostrou-se irregular, mas bastante interessante em alguns momentos; destacaremos três deles, já mostrados nas análises e que vamos agora retomar e destacar na presente discussão. No primeiro exemplo valorizamos os efeitos produzidos, no segundo exemplo, a análise institucional do discurso propriamente em ato e no terceiro a busca por reorientar o discurso.

Apresentamos então, o primeiro exemplo. Na sessão três a mediadora fez uma pontuação buscando mostrar a divisão de lugares produzida no discurso: "Vocês disseram antes algo que fez parecer que de um lado estão as pessoas deste grupo de vocês e que se encontram quando tem algo de bom e de outro, o resto". Esta fala gerou um movimento novo 
no grupo de relativizar o lugar de importância do Grupo 1 idealizado e uma quebra do pacto de concordância entre mediadora-grupo, levando o grupo a outros temas e a sair da divisão entre bons-ruins. A fala seguinte de Letícia pode exemplificar nossa afirmação: "Eu acho que não é uma coisa tão fechada assim, Juliana”, "a gente está sempre procurando outras coisas”, “não é mais aquele grupo”, “já pensamos bem diferente daquele tempo”.

Vamos ao segundo exemplo:

Mediadora - Quando eu falei para vocês que a gente estaria se reunindo para pensar no que é educação e fazer educação na Prefeitura, do ponto de vista do lugar institucional que vocês ocupam e constroem hoje, porque esse é a proposta que eu fiz pra esses encontros, pra analisar na minha pesquisa, nós estarmos aqui junto, vocês hoje estão falando muito das dificuldades e resistências com relação à administração e à estrutura da formação proposta pela prefeitura. Hoje a cena da formação foi toda isso. Dá uma sensação de lonjura da criança, do professor.

Maria - Lonjura ... acho que você me pegou.

Mediadora - Letícia, eu percebo pelas falas que vocês ocuparam o espaço de hoje, até agora, falando das lutas que vocês travam no dia a dia entre os formadores e que não ouvi as práticas que envolvem os professores e crianças das unidades de vocês. (s.3).

A pontuação analítica em ato propõe a possibilidade de montagem de outra cena e nela a reescrita do lugar, da posição, escolhida-produzida até o momento, que era de lutar com os formadores e com a administração.

No último exemplo podemos observar o que buscamos com a AID, uma reorientação do e no discurso, pois as participantes do grupo repetiam mais uma vez as mazelas que sofriam na prefeitura e apontavam caminhos teóricos como brechas e, também, situações concretas apresentadas como a "aposta" e assim se ancoravam em pontos de fuga com discussões sobre "a escola", "a sociedade".

Maria - A brecha é a produção de um espaço mais livre, que rompe com o instituído. Eu aposto nela! É o que temos... essa administração... 
Mediadora- Dentro de um contexto, do cotidiano da prefeitura, essas coisas são colocadas dessa forma por vocês [...] então a brecha seria o caminho, o caminho natural deste grupo reagir frente as iniciativas dessa gestão da prefeitura [...]

Rita - Fico pensando se a brecha é transformadora de algo. Não sei se muda, se algo é desconstruído, mas pelo menos faz você pensar de uma outra maneira. Acho que, talvez, o objetivo de agir na brecha seja resistir ao que foi pedido pra nós, seja até que mude o jogo. Não sei se a gente consegue chegar nessa mudança, mas pelo menos a gente tenta, reflete...enquanto isso vai sobrevivendo.

Maria - a gente pode falar da formação que fazemos... (trecho, s.4).

A reorientação apontou para desconhecimentos (o caminho "natural" repetido) e levou o grupo a falar da cena profissional e suas preocupações, como o "formar sem formatar" o outro e, nesta cena, não fazia mais sentido reclamar da administração e procurar as brechas ou a relação entre escola e sociedade. Nova cena, novas possibilidades de movimento, de assunção de lugares, de sentidos, de reconhecimentos e representações.

Segundo Barreto (2009, p.58), no exercício da AID em ato e em grupo o analista se coloca o desafio de escutar nos discursos "os movimentos de constituição e encaminhamento das relações institucionais grupais", na medida em que os membros do grupo falam sobre seu trabalho e sobre si. No grupo, uma dinâmica se faz e se refaz e, neste movimento, lugares são assumidos e atribuídos aos personagens presentes e aos citados nas falas. $O$ analista acompanha a dinâmica e com suas intervenções mobiliza os reconhecimentos e desconhecimentos produzidos nas relações.

Barreto (2009, p.60) elenca recursos que ajudam a escuta em ato e com grupos. Concordamos com ele que os recursos possíveis em ato são de um "outro nível de distanciamento" em relação ao que é possível perceber e analisar posteriormente, fora do jogo relacional do grupo. O autor lembra ainda que a AID é exercida a partir da formação pessoal de cada analista.

Acrescentamos que cada analista constitui um modo de trabalhar com o método, definido pela mistura das marcas institucionais e discursivas (das comunidades a que pertence e pertenceu), e pelo tempo de exercício e pertencimento a esta comunidade discursiva (dispositivo social que regula a produção e recepção do discurso, regra as condutas e produz pertença social). O que não quer dizer ecletismo, pois o método organiza um modo de pensar 
que é bastante rigoroso e cuidadoso, como pudemos demonstrar, e, através dos conceitos, balizam as produções, possibilitando regularidades (aquilo que reconhecemos como sendo AID e o que reconhecemos não ser AID), mas também singularidades (escolhas feitas a partir do método, ênfases, possibilidades novas e etc.).

Em ato, os acontecimentos se dão, jogamos o jogo dos discursos no qual controlamos e somos controlados por nossos interlocutores (e, mesmo assim, somos levados pelos desconhecimentos sempre presentes), estamos em meio, produzindo e produzidos, exercendo poder e resistência com nossos parceiros de fala, atribuindo lugares e recebendo expectativas. Os movimentos de misturar e de se diferenciar, de influenciar e resistir, fazem parte do jogo relacional em grupos, são produtivos. A possibilidade de reconhecer a si e ao outro, de reconhecer certos movimentos (regularidades e singularidades) e de marcar os lugares na relação (assumidas e atribuídas) é uma tarefa complexa para principiantes no método. Analisar relações institucionais de "pertença" (aquelas que fazemos, que temos filiação), é, da mesma forma, uma tarefa exigente que requer cortes e separações e que conta com limitações (aquilo que apesar da análise, se mantém como desconhecido). Analisar os movimentos presentes na sessão, durante a sessão, é um exercício analítico complexo, as hipóteses levantadas em ato contam com recortes da memória, que não são necessariamente fiéis aos procedimentos discursivos. O texto transcrito permite conferir com mais rigor as posições assumidas no discurso, inclusive pelo mediador-analista.

Fazer AID em ato e com grupos é uma modalidade rica de trabalho de análise como o presente trabalho mostrou, mas que precisou ser amparada com a AID feita após cada sessão, para exercer o corte que possibilitou o distanciamento da atual pesquisadora com relação à produção coletiva. Analisar o material produzido, no entanto, já distante do tempo das sessões foi um exercício que possibilitou a ampliação do olhar e o aprofundamento do trabalho em ato, enriquecendo as leituras dos discursos e os sentidos a que chegamos aos cortes e recortes feitos. 


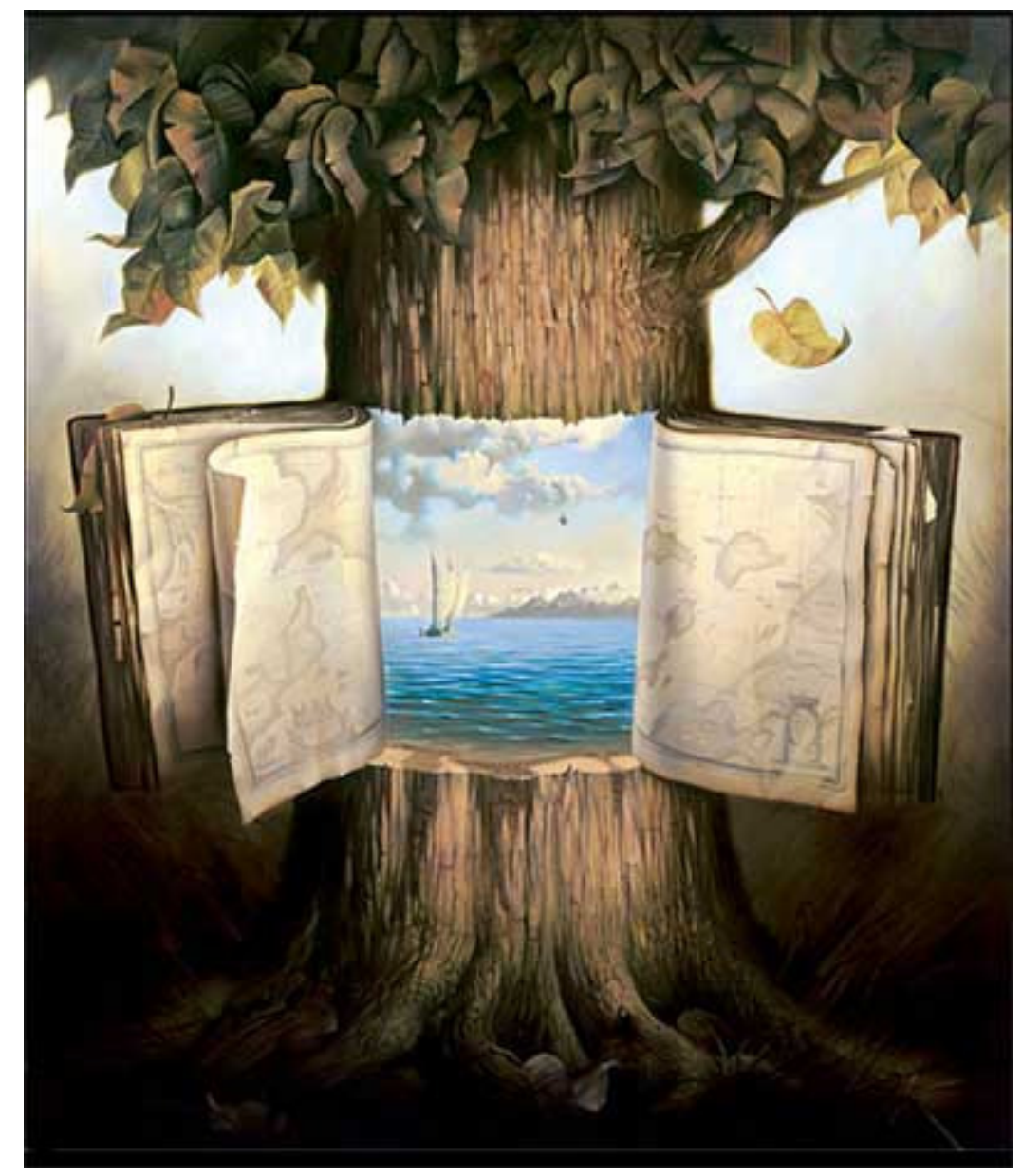

Fonte do texto visual: Salvador Dali, O livro árvore. 1959. 


\section{CONSIDERAÇÕES FINAIS}

Desde o começo da pesquisa, queríamos saber o que se passava com algumas educadoras-formadoras no exercício da função, o que significava compreender como esta formação se dava no ambiente de trabalho delas: a prefeitura municipal de São Paulo. Elas atravessavam um momento profissional especial: saiam da coordenadoria de educação como formadoras de uma gestão política e passavam a receber a formação e orientação de uma outra gestão e partido político. Intrigava e preocupava, naquele momento, o relato de pouca produção no trabalho, de desânimo, de conflitos nas relações, de desesperança, de depressão e as queixas em relação à formação continuada em serviço. Em busca de aprofundar nosso entendimento acerca da vivência destes profissionais buscamos ler alguns discursos de especialistas da área (teóricos da educação e pesquisadores) para conhecer o que trariam à cena e como apresentariam as questões da formação continuada em serviço, os personagens envolvidos e as relações entre eles. Por outro lado, procuramos escutar as educadoras pesquisadas, a respeito de como entendiam e representavam as suas experiências profissionais.

Muitas foram as descobertas: em relação aos alunos e pais como clientelas indiretas os discursos apontaram inadequações dos mesmos, que foram colocados em certos lugares de idealização (ser interessado, participativo, "adequado" ao seu lugar de estudante ou cidadão, por exemplo). Os conflitos foram apontados quando as famílias e os alunos não correspondiam aos lugares esperados. Em relação ao educador, ocorreu o mesmo, e foram considerados problemas as características de passividade, dependência, autoritarismo, falta de crítica, além de valorizadas as ações de reflexão que levariam o educador ao protagonismo. Os agentes foram idealizados em uma função educativa diferenciada dentro da carreira do educador: ser um formador "profissional" (que toma a tarefa como o seu compromisso e a sua identidade) e da formação participativa, crítica e transformadora de si e da escola. Neste sentido, todo um estudo sobre o seu perfil e formação já está em andamento, para fazer face aos problemas detectados. Porém, o dia a dia concreto das agentes-formadoras as distanciou do que foi valorizado e esperado nos discursos teóricos dos estudiosos e confirmou as preocupações iniciais que tanto nos intrigaram, especialmente por estarem presentes em um grupo de educadoras-formadoras consideradas por nós como “capazes e transformadoras”. 
Nas análises dos discursos encontramos recorrências que subjetivaram o lugar do educador e do formador (cliente e agente institucional) na prefeitura de São Paulo como um lugar de insuficiência (profissionais que precisam de muito investimento e de novas abordagens de trabalho em sua formação) e potencial (precisam ser valorizados em seus saberes e espaço para desenvolvimento de potenciais), o que ocorreu tanto no reconhecimento que as educadoras-formadoras-pesquisadas mostraram sobre si e sobre o trabalho, como na maneira como os estudiosos referiram-se a estes lugares profissionais.

Identificamos, repetidamente, agora nas falas das formadoras-pesquisadas, a dificuldade com o protagonismo, os conflitos incessantes nas relações, a justeza de espaço para criar em determinados momentos (relacionados a determinadas gestões públicas), a descontinuidade dos processos e o efeito que toda esta situação relatada gerou nelas de imobilização das ferramentas construídas ao longo da formação. As mudanças nos cenários políticos da formação as colocou em novos lugares institucionais que alteraram os valores em relação às concepções de trabalho e aos instrumentos usados. Outro efeito foi o da circularidade vivida em relação à subjetividade. As análises apontaram certos lugares ocupados por elas de forma recorrente e circular, os quais caracterizamos como lugares institucionais (ou formações subjetivas), nomeados como: recolhimento individual (vitimização, culpabilização, desqualificação), sujeição burocrática (passividade, apagamento de si, alienação), guerra (disputa, resistência, ataque e defesa), sobrevivência (aguardar, suportar, permanecer), amalgamento (parcerias, apoios e mitificação na busca de iguais). Mergulhadas nesta ciranda subjetiva, observamos como cada uma ocupou tais lugares a seu modo e fez ensaios de diferença e liberdade em relação às pautas subjetivas construídas institucionalmente.

Em meio a relações de poder e a resistências exercitadas, ocorreram as normatizações e as rupturas (expectativas que organizaram e desorganizaram as relações). No jogo de forças da formação continuada em serviço no espaço público municipal e, em sua tensão constante, delineamos os lugares acima que foram construídos e ocupados por um grupo de educadorasformadoras. Intersubjetividade.

Ser formador é uma diferença-igualdade de si que se produz culturalmente, no campo do coletivo em meio a prescrições e a liberdades possíveis encontradas em práticas concretas, dentro de um estrato social. A diferença-igualdade de si é resultado de possibilidades, escolhas e acontecimentos que se fazem nas relações, dentro de um campo produzido pelo 
entrecruzamento de diferentes vetores de força, entre atribuições de expectativas e tensões constantes, e que mudam ao longo do tempo.

Em nosso país, estamos mergulhados em um sistema (recente, se considerarmos a experiência e apropriação do exercício democrático) que elege seus representantes democraticamente através de eleições diretas, o que, enquanto oportuniza a alternância da gestão pública (e com isso propõe inversões e mudanças significativas nos jogos de poder), produz descontinuidades nos projetos das organizações, emperramentos, morosidade, burocratização, interrupções (entre muitos outros efeitos) nos serviços, e, sofrimento docente, como o que pudemos acompanhar através dos relatos das formadoras-pesquisadas. $\mathrm{O}$ exercício da política educacional e partidária atravessa, dirige e caracteriza as práticas da formação continuada em serviço na prefeitura de São Paulo. Na bibliografia analisada e nos discursos das formadoras encontramos um campo político organizado em torno de oposições e os personagens em relações de disputa de saberes. Os que estão no exercício da gestão geram dados, análises, hipóteses, práticas e teorias; os que não estão na gestão e a criticam ocupam o lugar da reflexão, da oposição, da resistência, entre outros, até que o jogo vire. $\mathrm{Na}$ vivência das formadoras, quando fora da gestão, encontramos a queixa e o pedido de poder "ao menos se queixar" (espaço de lamentar, de reclamar, de desabafar) e o mal estar em usar o tempo da docência e formação com ações burocráticas. Esta composição do exercício político, embora recorrente, não se constitui como o único modo possível. A pesquisa, nesse sentido, abre perguntas novas em torno do modo como outras cidades (comunidades e instituições) vivem (e se vivem) as alternâncias políticas e educacionais e seus efeitos nos atores institucionais.

As formadoras apresentaram um contexto relacional (e político) no qual debatem-se entre prescrições, imposições, potenciais, idealizações, caminhos oferecidos pelas teorias e pesquisas e, os caminhos já trilhados e que são referências que querem retomar e reinscrever, imposições concretas e as possibilidades que ocorrem ou que cavam e criam: circularidade, repetição e ensaios - pontos de fuga.

Para chegar às análises apresentadas, uma entre outras possíveis, fizemos cortes nas falas, a partir das referências declaradas no método, como foi demonstrado a partir da remontagem e das articulações e amarrações produzidas nos discursos das educadorasformadoras e em outros discursos trazidos de pesquisas e trabalhos teóricos sobre o tema da formação. Fomos, como não poderia deixar de ser, acompanhados pelos discursos com os 
quais conversamos e os que participam e já participaram de nossa formação, no que reconhecemos e desconhecemos sobre ela: a análise configurou então, um novo discurso.

Partimos de perguntas e preocupações que também contribuíram para marcar as lentes utilizadas e as trilhas percorridas, e (ainda bem!) além de reconhecer certos lugares subjetivos já anunciados inicialmente nas lógicas de assujeitamento das práticas de formação de educadores, também nos surpreendemos pelo caminho.

Com AID tivemos a preocupação de, durante as análises, procurar o que se constituiu como marca repetida pelo grupo naquelas cenas (queixas, resistências, choques de expectativas, oposições, mal-estar profissional, repetições e buscas) e naquele contexto relacional que apontou para as posições e cenas ocupadas em circularidade (como um labirinto), compondo caminhos de legitimação na representação de si. Procuramos, ainda, o que se constituiu como modo único de ocupação dos lugares institucionais - o jeito de uma formadora e não de outra, como no caso de Clara que desenhou para si algo singular a partir dos lugares dados pela ordem institucional e das posições ocupadas e repetidas no grupo pesquisado.

A tensão entre o que é singular (que pôde ser encontrado no jeito de cada uma viver o seu lugar profissional, bem como no jeito próprio do grupo) e o que é comum (o que se passa com os profissionais que fazem e recebem a formação continuada em serviço na prefeitura de São Paulo), entre o que os diferencia e o que os iguala, nos acompanhou fortemente durante todo o percurso. Produzir afirmações sobre a subjetividade construída nesta tensão se constituiu um exercício de grande aprendizagem, pois em nenhum momento esquecemos que cada unidade de escola municipal é constituída por marcas próprias, além de estar vinculada a uma coordenadoria de bairro que também possui características, e que, dentro da unidade, cada profissional tem uma história institucional e quando formam um grupo de trabalho ali dentro, o que se passa é mais uma vez de composição única.

"Sujeito dobradiça" constituído nas e constitutivo das relações institucionais concretas: acompanhamos como elas viveram seus sentimentos-conflitos-fantasias nas relações institucionais - como se reconheceram, que lugares ocuparam e atribuíram a si e aos outros.

Reconhecemos que, ao chegar a categorias subjetivas, abrimos novas possibilidades de reflexão em relação à função de formador na instituição pública, o que é uma contribuição no 
sentido de trazer novas luzes para a discussão da produção subjetiva nesta situação profissional. A esperança que se abre para nós é de mobilizar o regime de produção de verdades institucionais e ampliar as possibilidades de exercício de liberdade e invenção de si, a partir da discussão sobre as versões das histórias da formação e do formador, ao dar visibilidade aos modos de subjetivação produzidos e aos tipos de experiência de si vividas por um grupo de formadoras.

A presente pesquisa pode também, e assim esperamos, ajudar na problematização e questionamento das políticas públicas educacionais (em sua circularidade e descontinuidade) a partir dos seus efeitos de sofrimento, ambiguidade, desânimo, burocratização, conflito e insuficiência produzidos na vida profissional das formadoras. Outra contribuição importante é discutir o efeito bastante preocupante produzido nas formadoras, a partir dos novos lugares ocupados, de imobilização das ferramentas da formação construídas (instrumentos, saberes, metodologias, etc.). Os produtos da formação deveriam, em tese, oferecer base, direção, desenvolvimento, ampliação e aprofundamento das condições de trabalho e da atuação profissional, porém, pudemos observar o que se passou entre uma mudança de gestão políticoeducacional a outra, a um grupo de profissionais experientes. As formadoras, como dissemos ao longo do trabalho, têm trabalhos de formação (práticas, saberes e metodologias) organizados e sistematizados, e já circularam (sendo que algumas ainda lá trabalham) na prefeitura como formadoras da administração (central e de bairros) e tiveram a oportunidade de construir as suas concepções de trabalho e de fazer a gestão da formação de muitos educadores da rede.

E, de modo mais íntimo, esperamos contribuir com as formadoras-pesquisadas, para que possam, a partir deste trabalho, criar novas formas de relação entre os parceiros institucionais e consigo mesmas.

Com relação à contribuição metodológica (e teórica) desta pesquisa, creio que pudemos demonstrar como, com a ajuda da AID, a prática de formação de educadores foi se mostrando e se fazendo como instituição (nos discursos teóricos e nos discursos concretos que se deram nas sessões de grupo) e como o método possibilitou a analítica da subjetividade, em grupo e em ato. A pesquisa traz, nesse sentido, um diferencial: a maior parte das pesquisas em AID, até o presente momento, trabalhou com entrevistas que caracterizam o modo como cada entrevistado se vê em seu lugar institucional e que relata na relação com o entrevistador. Em sessões de grupo podemos acompanhar a dinâmica relacional dos atores institucionais e as 
expectativas mútuas instituindo lugares e representações, no ato mesmo da pesquisa; sendo ali atuadas. As intervenções do pesquisador-mediador também aparecem, claramente no jogo e desta maneira se prestam - no sentido de que se oferecem - à análise da sua produção. $O$ mediador estabelece um tipo diferente de relação, se expõe e se coloca para dentro da cena, o que representa, ao mesmo tempo, uma dificuldade na manutenção da distância necessária para analisar e atuar, e, uma contribuição didática do como as relações - institucionais - se dão. Do lugar de mediador, o pesquisador é convidado, não só a usar a AID como recurso para pensar e construir o trabalho, mas a viver o método na condução das sessões.

Outro diferencial desta pesquisa foi o trabalho feito em relação à revisão bibliográfica: ela foi levantada, pesquisada, lida, escolhida e analisada com os instrumentos do método da AID, o que possibilitou a apresentação do campo da formação, através de cenas, atores e suas relações e jogos de força; não se constituindo como uma repetição ou citação de autores.

Encerramos nosso trabalho certos de que a AID é um método muito interessante de mediação psicológica em grupo e pode ser exercida em ato, ainda mais quando precedidas de análises (posteriores) dos discursos, pelo menos para os iniciantes (como ocorre com a presente pesquisadora).

Assumo, neste momento, novamente, a primeira pessoa do singular, como o fiz na introdução da presente pesquisa. Comecei este percurso sozinha, com minhas indagações e, ao longo da caminhada, encontrei muitos parceiros que constituíram para mim o "nós" (primeira pessoa do plural) utilizado ao longo do trabalho.

Afirmo que escutar as educadoras-formadoras falarem de si, buscar transitar entre as representações que nos discursos se delineavam e a minha instituição de filiação (com as teorizações que me encaminhavam, às vezes, rápido demais para certos significados) foi uma experiência profissional e acadêmica desafiante e rica. Acredito, também, que a pesquisa se constituiu para mim um exercício de praticar a escolha, as relações de poder e as resistências em relação ao método e seus conceitos norteadores e, neste exercício, de dentro dele, encontrei a possibilidade de liberdade; e, neste momento, reencontrei a felicidade do trabalho e da produção acadêmica.

Pude pensar a formação e o lugar do formador com uma distância crítica e olhar as prescrições encontradas nos discursos e produzidas, também por mim, na relação com as educadoras-formadoras. Sistematizar a análise e a reflexão ajudou-me a sair de um lugar 
profissional já conhecido e tentar outros, o que tem sido muito rico, por colocar-me em movimento de trilhar caminhos, arriscar novos olhares, e assim, colher novos frutos e, em muitos momentos, "rir de mim mesma", pois o matriciamento institucional é um fato.

Termino a pesquisa vislumbrando desdobramentos que convidam à continuidade dos estudos em relação à produção do sofrimento e da possibilidade de liberdades e invenção de si - rotas de fuga - nas relações de trabalho, em educação.

Como psicóloga escolar, de dentro de uma prática - sempre institucional - ficar atenta às produções de lugares e expectativas que se dão entre os atores, sendo a psicóloga um deles, para analisar as montagens de cenas e das relações, bem como as apropriações possíveis em relação a si e ao objeto institucional. Para o campo da formação (formadores e educadores) o psicólogo pode oferecer a sua escuta que tem como foco o "sujeito- dobradiça" em busca da construção e reconstrução dos lugares institucionais. 


\section{Referências $^{45}$}

ANDRÉ, Marli. A pesquisa sobre formação de professores no Brasil. (1990-1998). In: CANDAU, Vera. (org). Ensinar e Aprender: sujeitos, saberes e pesquisas. Rio de Janeiro: DP\&A, 2002.

BANCO MUNDIAL (1986). El financiamiento de la educación en los países em desarrollo: opciones de política. Washington, D.C: 1986.

Disponível em: http://www.histedbr.fae.unicamp.br - Acesso em 15-10-2010.

(1992).Educación primaria. Washington, D.C: 1992.

Disponível em: http://www.histedbr.fae.unicamp.br - Acesso em 15-10-2010.

(1992). Lo que el trabajo requiere de las escuelas. Washington, D.C: 1992.

Disponível em: http://www.histedbr.fae.unicamp.br - Acesso em 15-10-2010.

(1995). Prioridades y estrategias para la educación. Washington, D.C: 1995. Disponível em: http://www.histedbr.fae.unicamp.br - Acesso em 15-10-2010.

(1995). La enseñanza superior: las lecciones derivadas de la experiência. Washington, D.C: 1995. Disponível em: http://www.histedbr.fae.unicamp.br - Acesso em 15-10-2010.

(1997). El Estado en un mundo en transformación. Washington, D.C: 1997.

Disponível em: http://www.histedbr.fae.unicamp.br - Acesso em 15-10-2010.

BARRETO, Ricardo Azevedo. Uma análise institucional do discurso em grupo com dentistas: cenas e posições. $198 \mathrm{f}$. Instituto de Psicologia da Universidade de São Paulo. Tese de doutorado. São Paulo: 2009. 
BRZENZINSKY, Iria. Profissão Professor: identidade e profissionalização Docente. Brasília: Plano Editora, 2002.

CARVAlHO, José Sérgio. Construtivismo: uma pedagogia esquecida da escola. Porto Alegre: Artmed, 2001.

COLLARES, Cecília; MOYSES, Maria. Construindo o sucesso na escola. Uma experiência de formação continuada com professores da rede pública. In: Educação Continuada. Caderno CEDES, n. 36. Campinas: 1995.

COLARES, Cecília; GERALDI, João; MOYSÉS, Maria. Educação continuada: a política da descontinuidade. In: Educação e Sociedade. Revista CEDES, n.68. Campinas: 1999.

CUNHA, Maria; LUDKE, Menga; MOREIRA, Antonio. Repercussões internacionais sobre a formação de nossos professores. In: Educação e Sociedade. Revista CEDES, n.69. Campinas: 1999.

DAVINI, Juliana. Um espaço singular para o psicólogo: grupos de formação de educadores orientados pela psicanálise e pela psicologia escolar. $221 \mathrm{f}$. Instituto de Psicologia da Universidade de São Paulo. Dissertação de mestrado. São Paulo, 2003.

DESTRO, Martha. Educação continuada: visão histórica e tentativa de conceitualização. In: Educação Continuada. Caderno CEDES, n. 36. Campinas: 1995.

DUARTE, Vanda Catarina. Capacitação docente em Minas Gerais e São Paulo: uma análise comparativa. Cadernos de Pesquisa. São Paulo, v. 34, n. 121, p. 139-168, jan./abr, 2004.

FOUCAULT, Michel. O sujeito e o poder. In: DREYFUS, Hubert e RABINOW, Paul. Uma trajetória filosófica: para além do estruturalismo e da hermenêutica. Rio de Janeiro: Forense Universitária, 1995. 
FOUCAULT, Michel. Ditos e Escritos. v. V. Ética, sexualidade e política. Organização e seleção de textos Manoel Barros da Motta. Rio de Janeiro: Forense Universitária, 2006.

História da sexualidade 1: a vontade de saber. São Paulo: Graal, 2007.

FREUD, Sigmund. Uma nota sobre o bloco mágico. Tradução sob a direção de Jayme Salomão. Rio de Janeiro: Imago, 1925/1976. Edição Standard Brasileira das obras completas de Sigmund Freud, volume XIX.

FUNDAÇÃO CARLOS CHAGAS. Avaliação externa Programa Um Salto para o Futuro. São Paulo: Fundação Carlos Chagas, 1993.

Avaliando Um Salto para o Futuro. São Paulo: Fundação Carlos Chagas, 1999.

Relatórios parciais e relatório final de atividade: avaliação externa. PEC- Formação Universitária, 2002-2003.

Relatórios técnicos: avaliação externa PEC-Municípios. São Paulo: Fundação Carlos Chagas, 2004-2007.

FUSARI, José e RIOS, Terezinha. Formação continuada dos profissionais do ensino. In: Educação continuada. Cadernos CEDES, n.36. Campinas: 1995.

GATTI, Bernadete. Por uma pedagogia de formação de professores- embates conceituais e crítica das políticas atuais. In: BARBOSA, Raquel (orgs). Trajetórias e perspectivas da formação de educadores. São Paulo: Unesp, 2005.

Análise das políticas públicas para formação continuada no Brasil, na última década. Revista Brasileira de Educação, v.13, n.37. Rio de Janeiro: ANPED, Autores Associados, 2008. 
GATTI, Bernadete. Marcos legais dos cursos de formação de professores. In: GATTI, Bernadete e BARRETO, Elba. (orgs). Professores do Brasil: impasses e desafios. Brasília: Unesco, 2009.

GUIRADO, Marlene. A Clínica psicanalítica na sombra do discurso. São Paulo: Casa do Psicólogo, 2000.

Psicanálise e análise do discurso: matrizes institucionais do sujeito psíquico. São Paulo: EPU, 2006. Edição revisada e ampliada.

GUIRADO, Marlene e LERNER, Rogério (orgs). Psicologia, pesquisa e clínica. Por uma análise institucional do discurso. São Paulo: Annablume, Fapesp, 2007.

GUIRADO, Marlene. Análise Institucional do discurso como analítica da subjetividade. 316 f. Instituto de Psicologia da Universidade de São Paulo. Tese de livre docência. São Paulo: 2009.

Análise Institucional do discurso como analítica da subjetividade. São Paulo: Annablume, 2010.

JACOBI, Pedro. Descentralização, política municipal de educação e participação no município de São Paulo. In: Relatos de Pesquisa, volume 2. MEC: Brasília, 2003.

LERNER, Rogério. Estudo Institucional do atendimento de uma criança diagnosticada como autista. 268f. Instituto de Psicologia da Universidade de São Paulo. Tese de doutorado. São Paulo: 2004.

LIBÂNEO, José; PIMENTA, Selma. Formação de profissionais da educação: visão crítica e perspectiva de mudança. In: Educação e Sociedade. Revista CEDES, n.69. Campinas: 1999.

LIMA, Maria do Socorro Lucena. A formação contínua do professor nos caminhos e descaminhos do desenvolvimento profissional. Faculdade de Educação da Universidade de São Paulo. 188 f. Tese de doutorado. São Paulo, 2001. 
LONGAREZI, Andréa; PRADA, Luiz e VIEIRA, Vânia. Concepção de formação de professores nos trabalhos da ANPED de 2003 a 2007. Caxambu: 2009. Disponível em: http://www.anped.org.br/reunioes/32ra/arquivos/trabalhos/GT08-5836--Int.pdf .

Acesso em 15/10/2010.

LONGO, Rose. (1995). A qualidade total começa e termina com educação - Brasília: IPEA, 1995. (RI IPEA/DPS, n.6/95).

LUCAS, Jozimas. A teoria na formação do educador: análise dos grupos de formação permanente de professores da secretaria municipal de educação de São Paulo. $212 \mathrm{f}$. Pontifícia Universidade Católica de São Paulo. Dissertação de mestrado. São Paulo, 1992.

MAINGUENEAU, Dominique. Discurso, corpo e voz: o ethos como vetor de análise. Conferência de Dominique Maingueneau, Sylvia Leser de Mello e Marlene Guirado. São Paulo: CAC escolar, 1995. 31p.

. Novas tendências em análise do discurso. Campinas, SP: Pontes, Unicamp, 1997.

MUSSI, Mônica. O grupo de formação e seus protagonistas: uma leitura institucional das práticas de formação docente em serviço. 199f. Faculdade de Educação da Universidade de São Paulo. Dissertação de mestrado. São Paulo, 2000.

NÓVOA, Antônio. (org). Os professores e a sua formação. Lisboa: Dom Quixote, Instituto de Inovação Educacional, 1992 a.

O passado e o presente dos professores. In: NÓVOA, Antônio (org). Profissão Professor. Porto: Porto Editora, 1992 b. 2 ed.

OLIVEIRA, Adolfo. Quando o professor se torna aluno: tensões, desafios e potencialidades da formação em serviço. 170 f. São Paulo: Faculdade de Educação da Universidade de São Paulo. Dissertação de mestrado. São Paulo, 2009. 
PEREIRA, Eliana. A formação e a organização estrutural: uma concepção de trabalho para a Coordenadoria de Educação. In: As redes da experiência: relatos reflexivos do grupo de educadores-formadores da Coordenadoria de Educação. São Paulo: SME, 2004.

PEREIRA, Marcos Villela. Nos supostos para pensar a formação e autoformação: a professoralidade produzida no caminho da subjetivação. In: Ensinar e Aprender: sujeitos, saberes, pesquisa. Rio de Janeiro: DP\&A, 2002.

PIMENTA, Selma Garrido. Formação de professores: saberes da docência e identidade do professor. In: FAZENDA, Ivani. (org). Didática e interdisciplinaridade. Campinas: Papirus, 1998.

De professores, pesquisa e didática. Campinas: Papirus, 2002.

POPKEWITZ, Thomas. Sociologia política de las reformas educativas. Madri: Morata, 1994.

Academic discourse, profissionalization, and the construction of the teacher in the USA. Helsinki, 1995. (mimeo).

PRADA, Luiz Eduardo Alvarado (org). Formación de Profesores em América Latina: diversos contextos socio-políticos. Bogotá: Ediciones Antropos Ltda, 2003.

RIOS, Terezinha. Compreender e ensinar: por uma docência da melhor qualidade. $2^{\mathrm{a}}$ ed São Paulo: Cortez, 2001.

Ética e competência. 12a ed. São Paulo: Cortez, 2002.

ROMANELLI, Otaíza. História da Educação no Brasil. Rio de Janeiro: Vozes, 2001.

ROSSI, Vera Lúcia. Desafio à escola pública: tomar em suas mãos seu próprio destino. In:

Políticas Públicas e Educação. Cadernos CEDES, n. 55. Campinas, 2001. 
SAVIANI, Dermeval. O legado educacional do "longo século XX Brasileiro". In: SAVIANI, D.; ALMEIDA, J.; SOUZA, R.; VALDEMARIN, V. O legado educacional do séc. XX. Campinas, S.P: Autores Associados, 2006.

SME - SP (1990). Grupos de formação: uma revisão da educação do educador. Cadernos de Formação n.1. DOT. São Paulo, 1990.

SOUZA, Denise Trento Rebello. Formação continuada de professores e fracasso escolar: problematizando o argumento da incompetência. In: Educação e Pesquisa, volume 32, número 3. Revista da Faculdade de Educação da USP. São Paulo, 2006.

SOUZA, Régis Luiz Lima. Formação continuada dos professores e professoras do município de Barueri: compreendendo para poder atuar. $236 \mathrm{f}$. Faculdade de Educação da Universidade de São Paulo. Dissertação de mestrado. São Paulo, 2007.

SOUZA, Vera Maria. Formação em serviço de professores da SME de São Paulo: 19562004. Gênese: transformações e desafios. 253 f. Faculdade de Educação da Universidade de São Paulo. Dissertação de mestrado. São Paulo, 2005.

UNESCO (1998). Educação: um tesouro a descobrir. Relatório para a UNESCO da Comissão Internacional sobre Educação para o século XXI. São Paulo: Cortez, Janeiro de 1998.

VAILLANT, Denise. Formacion de formadores: estado da pratica. PREAL, 2002. Uruguai: 2002. Disponível em:

http://www.oei.es/docentes/articulos/formacion_formadores estado_practica_vaillant.pdf-

Acesso em 17-10-2010.

ZANZINI, Soraia. (2000). A experiência dos grupos de formação na trajetória profissional dos educadores da rede municipal de ensino: marcas de uma permanência. 79 f. Pontifícia Universidade Católica de São Paulo. Educação. Dissertação de mestrado. São Paulo, 2000.

ZUCHETTO, Suzana. A educação no município de São Paulo e a formação dos educadores. Rio de Janeiro: Vozes, 2001. 


\section{ANEXO A: Leis, decretos e congressos internacionais}

1- LDBEN de 1961 - disponível em:

http://www6.senado.gov.br/legislacao/ListaPublicacoes.action?id=102346

Acesso em 11-11-2010.

2- Lei 4.024/1961 - disponível em:

http://legislacao.planalto.gov.br/legisla/legislacao.nsf/fraWeb?OpenFrameSet\&Frame=frmWeb2\&Src =/legisla/legislacao.nsf/Viw_Identificacao/lei\%25204.024-1961\%3FOpenDocument\%26AutoFramed Acesso em 11-11-2010.

3- LDBEN de 1971- disponível em:

http://www6.senado.gov.br/legislacao/ListaPublicacoes.action?id=102368

Acesso em 11-11-2010.

4- Lei 5.692- disponível em: http://portal.mec.gov.br/cne/arquivos/pdf/PNCP0697.pdf Acesso em 11-11-2010.

5- LDBEN de 1996 - disponível em: http://portal.mec.gov.br - Acesso em 11-11-2010.

6- Conselho Nacional de Educação - elabora e publica a Diretriz Curricular Nacional de 2001. Disponível em: http://portal.mec.gov.br/arquivos/pdf/resolucao2.pdf - Acesso em 11-11-2010

7- Conselho Nacional de Educação - aprova a resolução número 01 de 15/5/06

Disponível em: http://portal.mec.gov.br - Acesso em 11-11-2010.

8- MEC (2004; 2006; 2007) - disponível em: http://portal.mec.gov.br - Acesso em 11-11-2010.

9- MEC pela portaria ministerial n.1403/03. - disponível em:

http://www.scielo.br/scielo.php?pid=S1413-24782008000100006\&script=sci_arttext-

Acesso em 11-11-2010. 
10 - Banco Mundial 1995, 1999, 2002 - disponível em: http://web.worldbank.org/ Acesso em 11-11-2010.

11- PREAL 2004- disponível em: http://www.preal.org/Ing/Quienes.asp Acesso em 11-11-2010.

12- UNESCO 1998- disponível em: http://www.unesco.org/webworld/publications/index.shtml Acesso em 11-11-2010.

13- Fórum mundial 2000- disponível em: http://www.worldforum.org/conferences/forum2k.htm Acesso em 11-11-2010.

14- Cúpula das Américas 2001 - disponível em:

http://www.summit-americas.org/iii\%20summit/eng/iii\%20summit-eng.htm Acesso em 11-11-2010.

15- Decreto 6755/2009 - disponível em:

http://www.jusbrasil.com.br/legislacao/92458/decreto-6755-09

Acesso em 11-11-2010.

16- Banco Internacional para a Reconstrução e Desenvolvimento (BIRD) - ou Banco Mundial Disponível em: http://www.histedbr.fae.unicamp.br - Acesso em 15 - 10- 2010 
ANEXO B: Os prefeitos de São Paulo citados no trabalho

\begin{tabular}{|l|l|l|}
\hline 51. & Mario Covas & $11 / 05 / 1983-31 / 12 / 1985$ \\
\hline 52. & Jânio da Silva Quadros & $01 / 01 / 1986-31 / 12 / 1988$ \\
\hline 53. & Luiza Erundina de Souza & $01 / 01 / 1989-31 / 12 / 1992$ \\
\hline 54. & Paulo Salim Maluf & $01 / 01 / 1993-31 / 12 / 1996$ \\
\hline 55. & Celso Pitta & $01 / 01 / 1997-25 / 05 / 2000$ \\
\hline 56. & Régis de Oliveira & $26 / 05 / 2000-13 / 06 / 2000$ \\
\hline 57. & Celso Pitta & $14 / 06 / 2000-31 / 12 / 2000$ \\
\hline 58. & Marta Suplicy & $01 / 01 / 2001-31 / 12 / 2004$ \\
\hline 59. & José Serra & $01 / 01 / 2005-31 / 03 / 2006$ \\
\hline 60. & Gilberto Kassab & $31 / 03 / 2006$ \\
\hline
\end{tabular}

Disponível em:

http://ww1.prefeitura.sp.gov.br/portal/a_cidade/organogramas/index.php?p=574

Acesso em 17-11-2010 